UNIVERSIDADE ESTADUAL PAULISTA

"JULIO MESQUITA FILHO"

FACULDADE DE FILOSOFIA E CIÊNCIA - CAMPUS MARÍLIA/SP

AILA NARENE DAHWACHE CRIADO ROCHA

PROCESSO DE PRESCRIÇÃO E CONFECÇÃO DE RECURSOS DE TECNOLOGIA ASSISTIVA PARA EDUCAÇÃO INFANTIL

Marília- SP

2010 


\section{PROCESSO DE PRESCRIÇÃO E CONFECÇÃO DE RECURSOS DE TECNOLOGIA ASSISTIVA PARA EDUCAÇÃO INFANTIL}

Dissertação de Mestrado apresentada ao Programa de Pósgraduação em Educação da Faculdade de Filosofia e Ciências - UNESP - campus de Marília, como parte dos requisitos para obtenção do título de mestre em Educação.

Área de Concentração: Ensino na Educação Brasileira.

Linha de Pesquisa: Educação Especial no Brasil.

Orientadora: Prof ${ }^{\mathrm{a}}$ Dra $^{\mathrm{a}}$. Débora Deliberato 
Ficha Catalográfica

Serviço de Biblioteca e Documentação - UNESP - Campus de Marília

Rocha, Aila Narene Dahwache Criado.

R672p Processo de prescrição e confecção de recursos de tecnologia assistiva na educação infantil / Aila Narene

Dahwache Criado Rocha. - Marília, 2010. 199 f. ; $30 \mathrm{~cm}$.

Dissertação (Mestrado em Educação) - Faculdade de Filosofia e Ciências, Universidade Estadual Paulista, 2010. Bibliografia: f. 163-184.

Orientador: Profa. Dra. Débora Deliberato.

1. Educação especial. 2. Tecnologia assistiva. 3. Deficiência física. I. Autor. II. Título.

CDD 371.9 


\section{PROCESSO DE PRESCRIÇÃO E CONFECÇÃO DE RECURSOS DE TECNOLOGIA ASSISTIVA PARA EDUCAÇÃO INFANTIL}

Objetivo: Descrever o processo de prescrição e confecção de recursos de tecnologia assistiva para crianças com paralisia cerebral no contexto da Educação Infantil.

Dissertação de Mestrado apresentada ao Programa de Pós-graduação em Educação da Faculdade de Filosofia e Ciências - UNESP - campus de Marília, como parte dos requisitos para obtenção do título de mestre em Educação. Área de Concentração: Ensino na Educação Brasileira. Linha de Pesquisa: Educação Especial no Brasil.

\section{Orientadora: Prof ${ }^{\mathrm{a}} \mathrm{Dr}^{\mathrm{a}}$. Débora Deliberato}

Data de aprovação:

\section{BANCA EXAMINADORA}

Presidente e

Orientadora:

Prof ${ }^{\mathrm{a}} \mathrm{Dr}^{\mathrm{a}}$ Débora Deliberato

Docente do Programa de Pós Graduação em Educação, Faculdade de Filosofia Ciências da Universidade Estadual Paulista UNESP - campus de Marília/SP.

Membro Titular:

Profa. Dra. Maria Amélia de Almeida Docente do Programa de Pós Graduação em Educação Especial, Universidade Federal de São Carlos - UFSCAR campus de São Carlos/SP.

Membro Titular:

Dr $^{\mathrm{a}}$ Rita de Cássia Tibério Araújo

Docente do Departamento de Educação Especial, Faculdade 
Aos meus amores Paulo e Thales, por me ensinarem uma nova lição a cada dia, guias no meu caminho pela vida. Amor maior... 


\section{AGRADECIMENTOS}

Meus agradecimentos...

À Prof ${ }^{a}$ Débora, minha eterna gratidão, por ter me acolhido com paciência e carinho. Por ter sido firme e prestativa nos momentos cruciais. Por compartilhar o seu conhecimento. Por ter sido exemplo de dedicação, ética e trabalho em equipe. Por sua amizade.

Aos alunos e professores participantes, objetivo maior de toda a atividade científica. Mais que participantes de um trabalho acadêmico, verdadeiros mestres. Minha gratidão.

Aos participantes, titulares e suplentes, das bancas de qualificação e de defesa, pelas valiosas reflexões que me proporcionaram o aprimoramento deste estudo: $\operatorname{Dr}^{\mathrm{a}}$ Rita de Cássia Tibério Araújo, Prof ${ }^{a}$ Dr $^{a}$. Maria Amélia Almeida, $\operatorname{Prof}^{a} \operatorname{Dr}^{a}$ Ligia Maria Presumido Braccialli, Prof ${ }^{a}$ Dr ${ }^{\mathrm{a}}$ Dionísia Aparecida Cusin Lamônica.

Aos prezados colegas do Grupo de Pesquisa Deficiências Físicas e Sensoriais da UNESP de Marília, liderado pelo Prof. Dr. Eduardo José Manzini, pelas valiosas contribuições no delineamento e transcurso deste trabalho.

Aos funcionários da biblioteca, pela atenção carinhosa e auxílio a respeito das normas, busca por material bibliográfico, e elaboração da ficha catalográfica.

Aos amigos do Centro de Estudos da Educação e da Saúde -CEES - pelo respeito, auxilio e acolhimento durante este trabalho.

Aos funcionários da seção de Pós-graduação da Faculdade de Filosofia e Ciências de Marília - UNESP pelo atendimento competente e dedicado.

Aos professores e colegas do Programa de Pós-Graduação em Educação da UNESP Marília, pelos preciosos momentos de aprendizado durante as disciplinas, constante troca de idéias e apoio. 
A minha mãe, companheira de conquistas, amor e sonhos. Exemplo de determinação e dedicação. E por amar meus filho tanto quanto a mim.

A todos os que, embora não citados, me ofereceram apoio e amizade.

Muito Obrigada! 
Quem nada conhece, nada ama. Quem nada pode fazer, nada compreende.

Quem nada compreende, nada vale.

Mas quem compreende também ama, observa e vê.

Quanto mais conhecimento houver inerente numa coisa, tanto maior o amor.

Aquele que imagina que todos os frutos amadurecem ao mesmo tempo, como as cerejas, nada sabe a respeito das uvas.

Paracelso 


\section{RESUMO}

Tecnologia Assistiva é uma área do conhecimento, de característica interdisciplinar, que engloba produtos, recursos, metodologias, estratégias, práticas e serviços que objetivam promover a funcionalidade, relacionada à atividade e participação de pessoas com deficiência, incapacidades ou mobilidade reduzida, visando sua autonomia, independência, qualidade de vida e inclusão social. A tecnologia assistiva vem conquistando um espaço importante na educação proporcionando ao aluno com deficiência acessibilidade para o desenvolvimento de diferentes habilidades. A literatura tem discutido os benefícios do uso da tecnologia assistiva na Educação Infantil independente de condição física, intelectual ou emocional do aluno com deficiência, proporcionando a esse aluno acesso aos pré-requisitos para leitura e escrita e inserção social. O objetivo deste trabalho foi descrever o processo de prescrição e confecção de recursos da tecnologia assistiva para crianças com paralisia cerebral no contexto da Educação Infantil. A coleta de dados deste estudo foi dividida em cinco tarefas: na tarefa 1 a finalidade foi entender a situação, ou seja, obter informações a respeito das crianças e o seu contexto escolar e nas tarefas 2, 3, 4 e 5 o pesquisador teve como procedimentos gerar ideias, escolher as alternativas viáveis e representar a ideia para construir o recurso de tecnologia assistiva. Os procedimentos pertinentes à coleta de dados foram realizados nas escolas de dois alunos com paralisia cerebral selecionados. Os procedimentos foram registrados por meio de filmagem, diário contínuo, gravação das entrevistas e protocolo de registro e após a transcrição das fitas de áudio e vídeo as informações foram compiladas em um único documento escrito. A partir deste documento, foi realizada análise de conteúdo, estabelecendo categorias e subcategorias, que foram submetidas e delineadas como representativas pela indicação de juízes da área. Os resultados advindos desta análise, indicaram a caracterização dos dados obtidos na tarefa 1 em : 1) Recursos, 2) Estratégias, 3) Participação do aluno nas atividades, 4) Desempenho do aluno, 5) Conduta do aluno, 6) Interlocutores mediadores e 7) Ambiente das atividades. Após os resultados obtidos por meio da tarefa 1 foi possível gerar ideias a respeito do recurso, escolher as alternativas, representar a ideia e construir o recurso. Nas tarefas 2, 3, 4 e 5 foram utilizadas as informações obtidas na tarefa 1 e um protocolo foi elaborado para organização destas informações. Como resultados finais foram construídos para o participante A duas bolas, um chocalho, dois carrinhos, um acionador artesanal e quatro órteses; para o participante B um jogo de letras, um comunicador em forma de relógio, um acionador artesanal e um jogo de matemática. Foi possível concluir que para a prescrição do recurso de tecnologia assistiva foi necessário estabelecer etapas com procedimentos específicos, ou seja, foi necessário a implementação de programas de intervenção. A pesquisa também demonstrou que a sistematização das etapas de elaboração de recursos de tecnologias assistivas já discutidas pela literatura foi importante para o estabelecimento dos procedimentos propostos para realização das tarefas realizadas.

Palavras - Chave: Educação especial. Tecnologia assistiva. Deficiência física. 


\begin{abstract}
Assistive technology is an area of knowledge, interdisciplinary feature which comprehends products, resources, methodologies, strategies, practices and services that aim to promote capability related to activity and participation of people with disabilities, impairments or limited mobility targeting their autonomy, independence, quality of life and social inclusion. Assistive technology has gained an important status in education, providing access to disabled students to the development of different skills. The literature has discussed the benefits of using assistive technology in preschool programs regardless the physical, intellectual or emotional conditions of the disabled students, giving these students access to the requirements for reading and writing and social inclusion. The objective of this study was to manufacture assistive technology resources for children with cerebral palsy in the context of preschool education. The data collection of this study was divided into five tasks: task 1 aimed to understand the situation, that is, gather information about the children and their school context and in tasks 2, 3, 4 and 5 the researcher had to generate ideas, choose feasible alternatives and present the idea's prototype to build the assistive technology resource. The relevant procedures for data collection were conducted in the schools of the two selected students with cerebral palsy. The procedures were registered by continuous daily filming, recording of interviews and registration protocol and after the transcription of audio tapes and video, the information was compiled into a single written document. From this document, a content analysis was performed, establishing categories and subcategories that were submitted and outlined as representatives by the indication of judges in the area. The results derived from this analysis indicated the characterization of the data obtained in Task 1: 1) Resources, 2) Strategies, 3) Student Participation in Activities, 4) Student Performance, 5) Student Behavior, 6) Mediator Interlocutors, and 7) Activity Environment. After the results obtained from Task 1, it was possible to generate ideas about the resource, choose alternatives, represent the idea and build the resource. In tasks 2, 3, 4 and 5 the information obtained from task 1 was used and a protocol was designed to organize this information. As final results, two balls, one bib, two cars, a handcraft switch and four stents were adapted and built for participant A; a set of letters, a clock-shaped communicator, a handcraft switch and a math game were adapted and built for participant B. It was concluded that for prescribing the use of assistive technology, establishing steps with specific procedures was highly recommended, ie, it was necessary to implement intervention programs. The research also showed that the systematization of the steps for manufacturing the assistive technology resources already discussed in the literature was important to establish the proposed procedures for carrying out the tasks performed.
\end{abstract}

Key words: Special education. Assistive technology. Physical disability. 


\section{LISTA DE FIGURAS}

Figura 1 Fluxograma para desenvolvimento de tecnologia assistiva na escola

Figura 2 Fluxograma para desenvolvimento de tecnologia assistiva na escola

Figura 3 Esquema da atividade, tarefas e procedimentos de pesquisa

$\begin{array}{ll}\text { Figura } 4 \text { Bola } & 149\end{array}$

$\begin{array}{lc}\text { Figura } 5 \text { Trem adaptado } & \mathbf{1 5 0}\end{array}$

Figura 6 Plug para entrada do acionador $\quad \mathbf{1 5 0}$

Figura 7 Avião adaptado $\quad \mathbf{1 5 0}$

$\begin{array}{lr}\text { Figura } 8 \text { Plug para entrada do acionador } & \mathbf{1 5 0}\end{array}$

Figura 9 Ônibus adaptado $\quad \mathbf{1 5 0}$

Figura 10 Plug para entrada do acionador $\quad \mathbf{1 5 0}$

Figura 11 Acionador de pressão artesanal $\mathbf{1 5 2}$

Figura 12 Acionador acoplado ao brinquedo $\quad 152$

Figura 13 Chocalho $\quad 152$

Figura 14 Órteses de posicionamento $\quad 154$

Figura 15 Órtese para abdução do polegar $\quad 154$

Figura 16 Tabuleiro do Jogo das Letras

Figura 17 Tabuleiro do Jogo das Letras

Figura 18 Comunicador em Forma de Relógio $\quad \mathbf{1 5 6}$

$\begin{array}{ll}\text { Figura } 19 \text { Acionador } & 157\end{array}$

Figura 20 Jogo de Matemática $\quad 158$

$\begin{array}{ll}\text { Figura } 21 \text { Jogo de Matemática } & 158\end{array}$ 


\section{LISTA DE QUADROS}

Quadro 1 Descrição das tarefas da atividade de confeccionar recurso de

Tecnologia Assistiva

Quadro 2 Procedimentos e Instrumentos para coleta de dados da Tarefa 1

Quadro 3 Cronograma de atividades do Participante A

Quadro 4 Cronograma de atividades do Participante B $\mathbf{7 5}$

Quadro 5 Dados referentes ao Protocolo de Identificação da Rotina

Escolar

Quadro 6 Categorias e Subcategorias de Análise da Tarefa 1

Quadro 7 Elementos necessários para gerar idéias para a elaboração de recursos 


\section{LISTA DE TABELAS}

Tabela 1 Índice de Concordância obtido entre os juízes 


\section{SUMÁRIO}

$\begin{array}{lll}2.1 & \text { Tecnologia Assistiva } & \mathbf{1 7}\end{array}$

2.2 Tecnologia Assistiva e a Educação $\quad \mathbf{2 7}$

2.3 Deficiência Física e a Educação Infantil 37

2.4 O Brincar e a Tecnologia Assistiva na Educação Infantil 47

3 OBJETIVO 56

4 MATERIAL E MÉTODO 57

$4.1 \quad$ Aspectos Éticos $\quad 57$

4.2 Critérios de seleção dos participantes $\quad \mathbf{5 7}$

4.3 Características dos participantes $\quad \mathbf{5 8}$

$4.4 \quad$ Local e Período $\quad \mathbf{6 5}$

4.5 Materiais e Equipamentos $\quad \mathbf{6 5}$

4.6 Formas de Registro $\quad \mathbf{6 6}$

$\begin{array}{lll}4.7 & \text { Organização dos procedimentos metodológicos de pesquisa } & \mathbf{6 8}\end{array}$

$\begin{array}{lll}\text { 4.7.1 Tarefa1 }- \text { Entender a Situação } & \mathbf{7 0}\end{array}$

4.7.2 Tarefa 2 - Procedimentos para pensar no recurso $\quad \mathbf{8 3}$

4.7.3 Tarefa 3 - Procedimentos para escolher as alternativas $\quad \mathbf{8 5}$

4.7.4 Tarefa 4-Procedimentos para representar a idéia $\quad \mathbf{8 6}$

4.7.5 Tarefa 5 - Procedimentos para confecção do recurso de tecnologia $\mathbf{8 9}$ assistiva

5.1 Resultados e discussão da Tarefa 1: Entender a situação 90

5.2 Tarefas 2, 3, 4, 5: Prescrever e confeccionar o recurso de tecnologia $\mathbf{1 3 8}$ assistiva

5.3 Resultados e discussões da Tarefa 2: Pensar no recurso de 139 tecnologia assistiva

5.4 Resultados e discussões da Tarefa 3: Escolher as alternativas $\quad \mathbf{1 4 4}$

5.5 Resultados e Discussões Tarefa 4: Representar a idéia $\mathbf{1 4 5}$

5.6 Resultados e Discussões Tarefa 5: Confecção dos recursos de $\mathbf{1 4 8}$ tecnologia assistiva 
APÊNDICE A - Termo de consentimento livre e esclarecido dos

participantes

APÊNDICE B - Termo de consentimento livre e esclarecido dos professores

APÊNDICE C - Roteiro de entrevistas com as professoras 190

APÊNDICE D - Protocolo de Identificação da Rotina Escolar

APENDICE E - Protocolo de caracterização e dimensões do recurso

- Representação da idéia

ANEXOS

ANEXO A - Parecer de aprovação do comitê de ética

ANEXO B -Autorização da Secretaria de Educação de Marília 


\section{APRESENTAÇÃO}

Meu primeiro contato com a Tecnologia Assistiva aconteceu no final do ano 2000, quando tive que escolher junto a uma amiga o tema para o trabalho de conclusão da graduação em Terapia Ocupacional pela Faculdade de Educação Física de Lins - Centro Universitário Católico Salesiano Auxilium (1998-2001). Naquela ocasião, a Tecnologia Assistiva era uma área ainda incipiente no Brasil, então junto com a orientadora do projeto, a querida Professora Rosana Silvestre de Oliveira, optamos em implantar o serviço de Comunicação Suplementar e Alternativa no Centro de Reabilitação de Terapia Ocupacional Dom Bosco, local onde acontecia o estágio curricular de neurologia e reabilitação física do ultimo ano de graduação. Para dar início a esse trabalho foi necessário, além da busca de referenciais teóricos, o contato com profissionais que já utilizavam a Comunicação Alternativa e Suplementar. Nesse momento fomos acolhidas por duas terapeutas ocupacionais que já tinham experiência nesta área, a Doutora Myrian Pelosi e a Maria Madalena Morais Sant'anna. Após esta experiência com a tecnologia assistiva alguns questionamentos me faziam refletir sobre a minha formação, entre eles: será que as técnicas tradicionais de reabilitação física eram suficientes para garantir aos nossos pacientes a ampliação de suas habilidades e autonomia em seus diferentes contextos.

No ano de 2002, iniciei o Programa de Aprimoramento em Terapia Ocupacional na Faculdade de Medicina de Rio Preto, atuando na área de neurologia, desde a hospitalização do paciente até o seu acompanhamento ambulatorial. Essa experiência reforçou o meu prazer de atuação na área da habilitação e/ou reabilitação neurológica.

Ao longo do aprimoramento senti a necessidade de buscar respostas para as indagações que surgiam durante as intervenções. Nesse momento decidi cursar uma Pós Graduação Latu Sensu, Terapia Ocupacional - Uma Visão Dinâmica Aplicada a Neurologia. Essa especialização permitiu novamente contato com profissionais que utilizavam a tecnologia assistiva, aperfeiçoando meu conhecimento teórico prático sobre a temática. Foi realizado um trabalho de conclusão da especialização com o título: Diagnóstico situacional utilizado pelo terapeuta ocupacional na clínica de crianças com paralisia cerebral.

Em 2003, ao final do aprimoramento, fui contratada por uma APAE, que há algum tempo não tinha o profissional de Terapia Ocupacional. Essa condição me levou à necessidade de estruturar um novo serviço e já com a certeza de que apenas as técnicas de reabilitação habitualmente utilizadas por profissionais da terapia ocupacional não seriam 
suficientes para suprir as necessidades de crianças, jovens e adultos da instituição, também priorizei o uso da tecnologia assistiva.

Durante os cinco anos de atuação na instituição, pude contar com total apoio da direção e da equipe multidisciplinar. Durante esse tempo, foram desenvolvidos vários projetos com enfoque na tecnologia assistiva, dentre eles é possível destacar: a prescrição e confecção de órteses; a implantação do serviço de comunicação alternativa; a atuação junto ao professor em sala de aula a fim de identificar e confeccionar recursos de tecnologia assistiva necessários para o aluno; prescrição, confecção de recursos para atividades de vida diária; capacitação de professores, profissionais da saúde, cuidadores e familiares para o uso da tecnologia assistiva.

No período em que trabalhei na APAE, naturalmente me aproximei da educação especial. Para o aprimoramento do meu conhecimento sobre a educação, em 2004 iniciei uma especialização em Psicopedagogia, com o intuito de compreender melhor o processo de aprendizagem e as diferentes estratégias de aquisição do conhecimento. Nessa especialização desenvolvi uma pesquisa intitulada: A tecnologia assistiva auxiliando no processo do brincar de crianças com deficiência física na estimulação precoce.

Em 2005, realizei a especialização em Terapia de Mão, aprimorando meus conhecimentos em reabilitação de membros superiores e prescrição e confecção de órteses e adaptações.

No ano de 2007, fui aprovada em um concurso público para trabalhar como terapeuta ocupacional do Centro de Estudos da Educação e da Saúde (CEES), unidade auxiliar da UNESP de Marília, onde passei a fazer parte de uma equipe de profissionais que já realizavam um trabalho significativo nas áreas de ensino, pesquisa e extensão com a interface entre a saúde e a educação.

As atividades desenvolvidas no CEES, e o desejo de aprimorar e sistematizar os conhecimentos na área de Tecnologia Assistiva me aproximaram de um antigo objetivo, o Mestrado em Educação da UNESP de Marília. Para tanto procurei delinear um projeto a fim de visar à inclusão dos alunos com deficiência física nas escolas utilizando os recursos da Tecnologia Assistiva.

Em Março de 2008, junto com a Professora Doutora Débora Deliberato, que acreditou na proposta desta pesquisa, iniciei a elaboração desta dissertação. Como parte das atividades deliberadas, comecei a participar das reuniões do grupo de pesquisa Deficiências Físicas e Sensoriais, liderado pelo Professor Doutor Eduardo José Manzini, atividade essa essencial para o andamento deste estudo. 
Esta dissertação foi conduzida pelas discussões no grupo de pesquisa, pelos conhecimentos adquiridos em cada aula frequentada no programa, pela exaustiva revisão de literatura realizada, e por cada orientação com a incansável e querida Professora Débora Deliberato.

A literatura discute a importância da tecnologia assistiva na escola, principalmente com o aluno deficiente físico. Nestse contexto é possível identificar que os professores que trabalham na Educação Infantil, seja no ensino regular ou em classe especial, poderiam se apropriar da tecnologia assistiva para facilitar a participação do aluno com deficiência física nas atividades pedagógicas propostas.

A partir desta questão, foram identificados os seguintes questionamentos: Quais seriam os procedimentos necessários para o professor inserir um recurso de tecnologia assistiva para um aluno com deficiência física? Quais seriam os critérios para identificar, prescrever e confeccionar o recurso de tecnologia assistiva no contexto da Educação Infantil?

Face à essas questões, o objetivo desta pesquisa foi confeccionar recursos da tecnologia assistiva para crianças com paralisia cerebral no contexto da Educação Infantil. 


\section{INTRODUÇÃO}

\subsection{Tecnologia Assistiva}

Desde os primórdios da historia da humanidade o homem tem criado instrumentos para aumentar e compensar uma função, assim o uso de ferramentas e máquinas iniciou-se a partir da intenção de potencializar a função humana. No campo da reabilitação é possível observar a utilização de um arsenal de aparatos para compensar ou substituir funções quando as técnicas reabilitadoras não se apresentam de forma suficiente para restaurá-las em sua totalidade (CARLO; LUZO, 2004).

Este arsenal de aparatos é chamado de tecnologia assistiva, e nos últimos anos vem exercendo um importante papel na vida de pessoas com deficiências. Existe uma crescente conscientização da importância do uso de recursos de tecnologia assistiva, a fim de suprir as necessidades de indivíduos com deficiência em seu cotidiano (COOK; HUSSEY,1995, 2002; SORO-CAMATS, 2003; PELOSI, 2006, 2008, 2009; ANSON, 2007, NUNES, 2007; HUANG; SUGDEN; BEVERIDGE, 2009).

A tecnologia assistiva está muito próxima do nosso dia a dia, algumas vezes causam impacto devido à tecnologia que apresentam, outras passam quase despercebidas. Como exemplo pode se chamar de tecnologia assistiva uma bengala, utilizada por idosos com objetivo de proporcionar conforto e segurança no momento de caminhar; um aparelho de amplificação sonora utilizado por uma pessoa com surdez moderada; ou mesmo um veículo adaptado para uma pessoa com deficiência (MANZINI, 2005).

Documentos internacionais e nacionais têm procurado definir a tecnologia assistiva e garantir políticas publicas que favoreçam o seu uso.

A terminologia tecnologia assistiva foi utilizada oficialmente pela primeira vez nos EUA, no ano de 1988, em um importante elemento jurídico da legislação norte-americana, conhecida como Public Law 100-407, que contígua à outras leis formam o ADA (American with Disabilities Act). Este conjunto de leis tem o objetivo de regulamentar os direitos dos cidadãos com deficiência nos Estados Unidos, além de prover a base legal dos fundos públicos para o financiamento dos recursos que estes necessitam. Este documento definiu o termo tecnologia assistiva como: 
Os recursos e serviços que auxiliam pessoas com deficiências, entendendose como recursos de tecnologia assistiva qualquer item, equipamento ou sistema de produtos, adquiridos comercialmente, modificados ou feitos sob medida que são utilizados para aumentar, manter ou melhorar as capacidades funcionais de indivíduos com deficiência. $\mathrm{O}$ serviço de tecnologia assistiva é definido como qualquer serviço que assiste diretamente um indivíduo com uma deficiência na seleção, aquisição ou uso de um recurso de tecnologia assistiva (PUBLIC LAW 100-407, 1988, p. 07).

Além de definir do que se trata a tecnologia assistiva este documento descreveu quais os serviços de tecnologia assistiva:

1) A avaliação das necessidades do uso de tecnologia assistiva por um indivíduo com deficiência, incluindo uma avaliação funcional do impacto do uso da tecnologia assistiva apropriada e de serviços adequados para o indivíduo no seu contexto;

2) Um serviço que consista na compra, no empréstimo ou que de outra forma provenha a aquisição de recursos de tecnologia assistiva para pessoas com deficiências;

3) Um serviço que consista na seleção, desenvolvimento, experimentação, customização, adaptação, aplicação, manutenção, reparo, substituição ou doação de recursos de tecnologia assistiva;

4) Coordenação e uso de terapias necessárias, intervenções e serviços associados com educação e programas de reabilitação;

5) Treinamento ou assistência técnica para um indivíduo com uma deficiência ou, quando apropriado, aos membros da família, cuidadores, responsáveis ou representantes autorizados de tal indivíduo;

6) Treinamento ou assistência técnica para profissionais (incluindo indivíduos que proveem serviços de educação, reabilitação e de entidades que fabricam ou vendem recursos de tecnologia assistiva), empregadores, serviços provedores de emprego e treinamento, ou que estão de outra forma, substancialmente envolvidos nas principais funções de vida de indivíduos com deficiência;

7) Um serviço que consista na expansão da disponibilidade de acesso à tecnologia, incluindo tecnologia eletrônica e de informação para indivíduos com deficiências (PUBLIC LAW 108-364, 2004).

No domínio europeu os termos identificados como sinônimos de tecnologia assistiva foram: ajudas técnicas ou tecnologia de apoio. O consórcio EUSTAT - Empowering 
Users Through Assistive Technology, utiliza a expressão tecnologias de apoio, para definir todos "os produtos e serviços capazes de compensar limitações funcionais, facilitando a independência e aumentando a qualidade de vida das pessoas com deficiência e pessoas idosas" (EUSTAT, 1999, p. 15).

$\mathrm{Na}$ legislação brasileira o termo ajudas técnicas apareceu oficialmente no Artigo 19 do Decreto Lei ${ }^{\circ} 3298$, de 20 de dezembro de 1999 ao definir ajudas técnicas como:

Os elementos que permitem compensar uma ou mais limitações funcionais, motoras, sensoriais ou mentais da pessoa portadora de deficiência, com o objetivo de permitir-lhe superar as barreiras da comunicação e da mobilidade e de possibilitar sua plena inclusão social (BRASIL, 1999).

Foi possível identificar neste documento quais são os recursos que consideradas ajudas técnicas:

1) Próteses auditivas, visuais e físicas;

2) Órteses que favoreçam a adequação funcional;

3) Recursos e elementos necessários à terapia e reabilitação de pessoas com deficiência;

4) Recursos, maquinarias e utensílios de trabalho especialmente desenhados ou adaptados para uso por pessoa com deficiência;

5) Recursos de mobilidade, cuidado e higiene pessoal necessários para facilitar a autonomia e a segurança da pessoa com deficiência;

6) Recursos especiais para facilitar a comunicação, a informação e a sinalização para pessoas com deficiência;

7) Recursos e material pedagógico especial para educação, capacitação e recreação da pessoa com deficiência;

8) Adaptações ambientais e outras que garantam o acesso, a melhoria funcional e a autonomia pessoal; e

9) Bolsas coletoras para os portadores de ostomia (BRASIL, 1999).

O Artigo 61 do Decreto Lei $n^{\circ} 5296$ de 2/12/2004 que regulamentou a Política Nacional para a Integração da pessoa com deficiência definiu ajudas técnicas como:

Os produtos, instrumentos, equipamentos ou tecnologia adaptados ou especialmente projetados para melhorar a funcionalidade da pessoa 
portadora de deficiência ou com mobilidade reduzida, favorecendo a autonomia pessoal, total ou assistida (BRASIL, 2004).

Ainda no Decreto 5296/2004 no Artigo 66 foi previsto a criação de um Comitê de Ajudas Técnicas, que foi instituído pela portaria 142 de 16 de novembro de 2006 (Brasil, 2006). O Comitê de Ajudas Técnicas (CAT) é um comitê permanente criado no âmbito da Secretaria Especial dos Direitos Humanos da Presidência da República (SEDH/PR), ligado a Coordenadoria Nacional para a Integração da Pessoa Portadora de Deficiência (CORDE). Conforme determina o Artigo $1^{\circ}$ da Portaria que o instituiu, o CAT é responsável por:

1) Elaborar e aprovar o regimento interno e o plano de ação do Comitê de Ajudas Técnicas;

2) Monitorar o cumprimento das ações e medidas constantes no plano de ação do Comitê de Ajudas Técnicas;

3) Apresentar propostas de políticas governamentais e parcerias entre a sociedade civil e órgãos públicos referentes à área de ajudas técnicas;

4) Estruturar as diretrizes da área de conhecimento;

5) Realizar levantamento dos recursos humanos que atualmente trabalham com o tema;

6) Detectar os centros regionais de referência em ajudas técnicas, objetivando a formação de uma rede nacional integrada;

7) Estimular nas esferas Federal, Estadual, Municipal, a criação de centros de referência em ajudas técnicas;

8) Propor a criação de cursos na área de ajudas técnicas, bem como o desenvolvimento de outras ações com o objetivo de formar recursos humanos qualificados na área; e

9) Propor a elaboração de estudos e pesquisas relacionados com o tema de ajudas técnicas (BRASIL, 2006).

A partir de estudos realizados pelo CAT, foi sugerido que as expressões ajudas técnicas, tecnologia assistiva e tecnologia de apoio, continuem sendo entendidas como sinônimos, porém foi estabelecida a utilização única da expressão tecnologia assistiva em seus documentos, e que esta expressão seja utilizada no singular, pelos seguintes motivos: este termo é uma tendência nacional já firmada no meio acadêmico, nas organizações de pessoas com deficiência, em setores governamentais, institutos de pesquisa e no mercado de produtos; 
a expressão tecnologia assistiva seria a mais compatível como a denominação de uma área de conhecimento, a ser oficialmente reconhecida; acredita-se ser uma expressão bastante específica o conceito ao qual representa, diferentemente das expressões ajudas técnicas e tecnologia de apoio, que são mais genéricas (CAT, 2007a).

Na reunião III realizada em abril de 2007 o CAT aprovou as bases conceituais que situam a tecnologia assistiva como sendo uma área de conhecimento com caráter multidisciplinar que tem por objetivos promover a funcionalidade de pessoas com deficiência, mobilidade reduzida ou idosa, e assim visar a sua autonomia, independência, qualidade de vida e inclusão social. Também foi definido que a tecnologia assistiva é composta por produtos, recursos, estratégias, práticas, processos, métodos e serviços. A formulação conceitual se propõe a considerar também os princípios do Desenho Universal e da Tecnologia Social (CAT, 2007b).

Em ata da reunião VII que aconteceu em dezembro de 2007, o CAT aprovou a adoção da seguinte conceito de Tecnologia Assistiva:

Tecnologia Assistiva é uma área do conhecimento, de característica interdisciplinar, que engloba produtos, recursos, metodologias, estratégias, práticas e serviços que objetivam promover a funcionalidade, relacionada à atividade e participação de pessoas com deficiência, incapacidades ou mobilidade reduzida, visando sua autonomia, independência, qualidade de vida e inclusão social (CAT, 2007c).

Estudiosos da área têm discutido sobre a tecnologia assistiva em suas pesquisas e pontuam não só a sua definição como também seus objetivos e aplicação.

$\mathrm{Na}$ literatura internacional as definições de tecnologia assistiva enfatizam o uso de recursos estratégias e serviços aplicados para atenuar os problemas funcionais encontrados pelos indivíduos com deficiências e proporcionar ou ampliar suas habilidades e, consequentemente, promover independência, qualidade de vida e inclusão (PHILLIPS; ZHAO, 1993; COOK; HUSSEY,1995, 2002; KING, 1999; LAHM; SIZEMORE, 2002; JOHNSTON; EVANS, 2005; VERZA et al., 2006; JUDGE; FLOYD; JEFFS, 2008).

A tecnologia assistiva ajuda pessoas com alguma incapacidade a executar atividades difíceis ou até mesmo impossíveis de serem realizadas. Esses recursos possibilitam que as pessoas com deficiência participem da sociedade, contribuindo como membros da comunidade (PHILLIPS; ZHAO, 1993, QUIST; LLOYD,1997, BAIN, 1998; KING,1999; LAHM; SIZEMORE, 2002, STEELMAN, 2002; JUDGE 2006; ANSON, 2007). 
Segundo o Centro Nacional para Estatísticas de Saúde dos Estados Unidos, em 1990, mais de 13,1 milhões de americanos já utilizavam recursos de tecnologia assistiva para melhorar uma incapacidade física (LAPLANTE; HENDERSHOT; MOSS, 1992).

No Brasil a tecnologia assistiva é uma área de conhecimento relativamente nova e o termo ajudas técnicas aparece como sinônimo de tecnologia assistiva (NUNES, 2007).

Quando a literatura discute sobre os recursos da tecnologia assistiva pontuam que envolve áreas como: a mobilidade alternativa que compreende o uso de cadeira de rodas, andadores e pranchas de deslocamento; a adequação postural; o acesso ao computador e suas adaptações; as adaptações para realização das atividades de vida diária como adaptações para higiene e alimentação; as adaptações para o trabalho; a acessibilidade e adaptação de ambientes incluindo rampas, banheiros adaptados e cozinhas adaptadas; o transporte adaptado que envolve veículos adaptados e cadeiras especiais; a adaptação de atividades escolares; as adaptações de equipamentos para lazer e recreação e, a comunicação alternativa e ampliada (KING, 1999; BARNES; TURNER, 2001; ANSON, 2005; LAUAND, 2005; PELOSI, 2006, 2008, 2009; CAVALCANTI; GALVÃO, 2007; BERSH, 2008)

Os recursos podem ser classificados como de baixa ou alta tecnologia, dependendo da forma com que são confeccionados, sua complexidade e o seu custo final. Desta forma é possível caracterizar os recursos da seguinte forma:

1) Recursos de baixa tecnologia: são os recursos produzidos de maneira artesanal e individualizados, exigem pouca sofisticação e são confeccionados com materiais de baixo custo. Pode-se citar alguns exemplos como: órteses; recursos pedagógicos adaptados; pasta de comunicação alternativa; mobiliário adaptado de madeira, utensílios para atividades de vida diária;

2) Recursos de alta tecnologia: são compostos por equipamentos mais elaborados, fabricados em escala industrial e que exigem profissionais especializados para a sua confecção. Quanto à sua utilização geralmente é necessário controle de computador ou eletrônico, tem-se como exemplo os vocalizadores e sistemas de controle ambiental e computadores (QUIST; LLOYD,1997; WASSON, ARVIDSON, LLOYD, 1997; SORO CAMATES, 2003; SUÀREZ, 2003; ANSON, 2007, BRACCIALLI, 2007).

A utilização dos recursos de tecnologia de forma precoce possibilita ao indivíduo adquirir mais facilmente o aprendizado cognitivo, emocional e motor, e ainda a motivação em 
geral, independente do seu tipo de deficiência (SULLIVAN, LEWIS 2000; SORO CAMATS, 2003; JUDGE, 2006; ROCHA et al., 2008; BRACCIALLI, 2009).

Em pesquisa realizada por Judge (2006), foram realizadas 38 entrevistas com profissionais da educação especial que trabalhavam com crianças na Educação Infantil, com objetivo de avaliar quais recursos de tecnologia assistiva eram mais úteis para trabalhar com crianças com deficiência. Os resultados indicaram que os recursos de comunicação alternativa e de baixa tecnologia foram considerados mais úteis. Os resultados apontaram que estes recursos permitiram a participação nas atividades de aprendizagem e quando utilizados na infância, favorecem a participação numa base de igualdade com seus pares em diferentes contextos, facilitando o processo do seu uso eficientemente em outras etapas da vida.

Pesquisadores da área alertam que ao iniciar o processo de implementação da tecnologia assistiva é necessário conhecer o usuário destes recursos, sua história, suas necessidades e desejos, bem como identificar quais são as necessidades reais considerando todo o seu contexto social e as possíveis barreiras que limitem a sua independência (SORO CAMATS, 2003; PARETTE; BROTHERSON, 2004).

Apesar de inúmeras pesquisas demonstrarem que a tecnologia assistiva proporciona resultados favoráveis no cotidiano de pessoas com alguma limitação funcional, é possível observar um elevado número de pessoas que se nega a utilizar os seus dispositivos. Estudos publicaram taxas sobre o abandono dos dispositivos que variam de $8 \%$ para $75 \%$ (PHILLIPS; ZHAO, 1993; TEWEY; BARNICLE; PERR, 1994; GITLIN, 1995; JOHNSTON; EVANS, 2005; VERZA et al., 2006; BRACCIALLI, 2007).

Essas taxas elevadas de abandono da tecnologia assistiva sugerem que muitas pessoas estão insatisfeitas com seus recursos o que resulta a suspensão de seu uso. O abandono desses recursos além de deixar de beneficiar esses usuários representa um desperdício de tempo e dinheiro para os profissionais, famílias e órgãos públicos.

É necessário compreender os fatores que podem influenciar a escolha de um indivíduo a utilizar os recursos da tecnologia assistiva, e assim direcionar as intervenções de forma a executar um trabalho específico com o objetivo de diminuir as taxas de abandono destes recursos (PHILLIPS; ZHAO, 1993; GITLIN, 1995; JOHNSTON; EVANS, 2005; REIMER-REISS; WACKER, 2000; BRACCIALLI, 2007).

Cook e Hussey (2002), apontaram em seus estudos a necessidade de retirar a ênfase dada ao recurso e direcioná-la para a aplicação do conhecimento da tecnologia 
assistiva. Para isso a tecnologia assistiva deve envolver além de recursos: serviços, estratégias e práticas que são criadas para melhorar os problemas enfrentados pelo deficiente.

Huang, Sugden e Beveridge (2009), realizaram um estudo com o objetivo de explorar o uso de recursos da tecnologia assistiva em casa, por crianças com paralisia cerebral com o objetivo de avaliar os fatores relacionados com a utilização destes recursos considerando a perspectiva da criança. Para isso foram utilizadas entrevistas semi-estruturadas como o principal instrumento de coleta de dados. Estiveram envolvidos no estudo 30 participantes, sendo 15 crianças com paralisia cerebral e 15 mães. Os resultados mostraram uma baixa frequência no uso dos recursos em casa pelas crianças participantes. Os pesquisadores identificaram quatro fatores que poderiam estar contribuindo para o não uso dos recursos: a resistência das crianças em utilizar os recursos, as baixas perspectivas das mães, as barreiras físicas e o ambiente não apropriado. Segundo os pesquisadores os resultados destacaram a necessidade de considerar três fatores ao se prescrever a utilização de recursos da tecnologia assistiva: as características do indivíduo, as características do recurso e os fatores ambientais.

O estudo anterior demonstrou a relevância de entender tecnologia assistiva, não somente como recursos equipamentos e ferramentas que proporcionam funcionalidade ao deficiente, mas considerar os serviços e estratégias utilizadas.

Estudos têm discutido que os profissionais não têm conhecimento dos serviços e estratégias que promovem o uso dos recursos da tecnologia assistiva, ficando este domínio restrito a centros especializados (EDYBURN; GARDNER, 1999).

As pesquisas enfatizam que é necessário que os profissionais que trabalhem com deficientes estejam preparados para prestar serviços da tecnologia assistiva que consistam na avaliação e identificação das habilidades e necessidades; na prescrição e confecção dos recursos; no acompanhamento, bem como perceber necessidades de modificações destes recursos durante a sua utilização. Para que esses serviços se efetivem é necessário desenvolver estratégias de intervenção a fim de mediar o uso dos recursos de tecnologia assistiva (MANZINI, 1999; MANZINI; SANTOS 2002; DELIBERATO, 2005; MANZINI, DELIBERATO; BRACCIALLI, 2006; PELOSI 2008, 2009; ROCHA; DELIBERATO; 2009a, 2009b).

Para que seja possível definir os conceitos de recursos, serviços e estratégias de tecnologia assistiva é necessários entender o contexto no qual eles são utilizados. As demandas para o uso da tecnologia assistiva surgem a partir de tarefas, ou seja, ações 
necessárias para a execução de uma atividade. Para a realização das tarefas de uma atividade a criança com deficiência pode necessitar de materiais ou recursos, estratégias e serviços da tecnologia assistiva.

Com intuito de auxiliar na compreensão do termo atividade, foi utilizado referencial teórico da terapia ocupacional, desta forma a American Occupational Therapy Association (AOTA, 1997), definiu como atividade conjunto de tarefas em sequencia que as pessoas desempenham durante a vida para preencher o seu tempo e trazer algum significado ou um sentido. As atividades podem ser tarefas simples, como o ato de brincar ou levar alimentos à boca ou mais complexas como dirigir um automóvel ou utilizar um computador.

A atividade envolve diversas tarefas em sequência, ou seja, para realizar uma atividade são necessárias várias ações de quem a realiza. Neste contexto Hagedorn (1999), descreveu que a divisão em tarefas possibilita uma análise mais detalhada da atividade o que facilita a identificação das habilidades motoras, cognitivas, perceptivas e interativas, além da análise dos movimentos necessários para o seu desempenho.

A análise da tarefa permite observar o desempenho de um indíviduo para identificar a complexidade da atividade, a capacidade funcional do indivíduo para realizá-la, os equipamentos e materiais necessários (recursos), as adaptações necessárias e os fatores de risco.

Molina e Arnaiz (2001), relataram que a análise da atividade oferece dados para que seja definido o recurso que será utilizado, qual o tipo de material, o custo, o tempo despendido, o ambiente adequado e as ajudas necessárias (estratégias). Os autores apontaram ainda que a partir destes dados é possivel adaptar a atividade, simplificá-la ou torná-la mais complexa.

A literatura discutiu que a tecnologia assistiva pode proporcionar adequação das demandas que surgem a partir de uma atividade, ou seja, possibilita a adaptação na forma em como ela é realizada (SORO-CAMATS, 2003; CAVALCANTE; GAVÃO, 2007; MANZINI, 2005; DELIBERATO, 2007; ROCHA; DELIBERATO, 2009a, 2009b).

Para a adequação das atividades Young e Quinn (1992), descreveram itens a serem considerados na atividade: as habilidades do sujeito, o ambiente, os recursos utilizados, os passos e procedimentos que envolvem a atividade e o resultado esperado.

$\mathrm{O}$ indivíduo com deficiência pode apresentar prejuízos em seu desempenho dificultando a sua participação nas atividades em diferentes contextos. A tecnologia assistiva é a ferramenta utilizada por diferentes profissionais e possibilita o uso de equipamentos, 
dispositivos, materias, objetos, produtos, a modificação do ambiente e mudanças nos procedimentos de execução das tarefas de uma atividade.

Esta pesquisa envolve a temática da tecnologia assistiva, porém antes de dar continuidade às discussões é preciso definir os conceitos a serem utilizados, referentes aos recursos, serviços e estratégias da tecnologia assistiva adotados neste estudo. Sendo assim, as definições adotadas foram:

Serviços: trabalho oferecido por profissionais de diversas áreas como a terapia ocupacional, fisioterapia, fonoaudiologia, engenheiros, professores, psicólogos, arquitetos, entre outros;

Recursos: são objetos, materiais, dispositivos, produtos e equipamentos utilizados com o objetivo de favorecer as habilidades do indivíduo e ampliar o seu desempenho e participação em uma determinada atividade. O recurso é um material concreto com atributos que podem ser modificados de acordo com a especificidade do indivíduo;

Recurso adaptado ou recurso de tecnologia assistiva: material concreto modificado e adequado segundo as necessidades do indivíduo, podendo sofrer modificações em relação a sua estrutura, forma, tamanho, peso, textura, conteúdo, entre outros. Desta forma mesmo sem modificar a sua condição orgânica o uso de um recurso de tecnologia assistiva é capaz de ampliar as habilidades do indivíduo em uma determinada atividade;

Procedimento: são os atos ou efeitos de realizar as tarefas de uma atividade, ou seja, são os métodos e técnicas utilizados durante a realização da atividade;

Estratégias: são procedimentos de execução a fim de mediar o uso dos recursos da tecnologia assistiva para a realização de uma atividade. As estratégias na tecnologia assistiva podem modificar ou ajustar a técnica utilizada para a realização da atividade para contornar as dificuldades do indivíduo e melhorar o seu desempenho e participação.

Perante tais definições, cabe salientar a importância dos diferentes profissionais atuantes na área de tecnologia assistiva para ampliar as ações quanto aos recursos, estratégias e procedimentos frente às diversidades dos alunos com deficiência nos diferentes contextos, como no caso do ambiente escolar (ARAÚJO; DELIBERATO; BRACCIALLI, 2009; SCHIRMER, 2009). 


\subsection{Tecnologias Assistiva e a Educação}

O Censo Demográfico realizado no Brasil no ano 2000 informa que 24,5 milhões de brasileiros têm algum tipo de deficiência, este número corresponde a 14,5\% da população do país (IBGE, 2009).

Em relação à educação, o Instituto Nacional de Estudo e Pesquisas Educacionais Anísio Teixeira (INEP) realiza anualmente o Censo Escolar da Educação Básica com o objetivo de identificar informações estatístico-educacionais sobre as diferentes etapas e modalidades da educação básica, junto aos estabelecimentos de ensino públicos e privados de todo o país (INEP, 2008).

Segundo o INEP (2008), em 2007 foram identificados na educação básica 654.606 de matrículas de alunos com necessidades educacionais especiais, o que corresponde a 1,2\% do total da matrícula nesse nível de ensino. Essas matrículas se distribuíram entre as redes de ensino Municipal (38,2\%), privada (37,3\%) e Estadual (24,3\%) e nas escolas Federais $(0,2 \%)$.

Em relação ao tipo de atendimento oferecido pelas escolas, 46,8\% das matrículas são atendidas em classes comuns do ensino regular e da educação de jovens e adultos (EJA), $41,3 \%$ em escolas exclusivamente especializadas e 11,9\% em classes especiais do ensino regular e da EJA (INEP, 2008).

Os dados referentes às escolas públicas demonstraram que o atendimento educacional é realizado predominantemente em classes comuns do ensino regular, correspondendo a 69,7\% das matrículas da educação especial. As escolas privadas adotaram, preferencialmente, o atendimento educacional exclusivamente especializado, com $87,4 \%$ do total das matrículas da educação especial em escolas especializadas e exclusivas para alunos com necessidades educacionais especiais. É importante ressaltar que entre as escolas privadas se encontram as instituições filantrópicas sem fins lucrativos com atuação exclusiva na educação especial e conveniadas com o poder público (INEP, 2008).

A tecnologia assistiva vem conquistando um espaço importante na educação especial no Brasil. Apesar de não encontrar uma quantidade abrangente de literatura nesta área, nos últimos anos pode-se observar o aumento significativo de estudos sobre esta temática. Estes estudos enfatizaram o uso de tecnologia assistiva na educação especial por meio de recursos, serviços e estratégias que vem a colaborar com a acessibilidade, com o processo de aprendizagem e com o desenvolvimento das habilidades de alunos com deficiências (CONNERS; JOHNSON, 2001; BARNES; TURNER, 2001; MANZINI; SANTOS, 2002; 
DELIBERATO, 2004, 2009a, 2009b; BERSCH, 2006; COPLEY; ZIVIANI, 2004; GUARDA,; DELIBERATO, 2006; JUDGE, 2006; OKOLO; BOUCK , 2007; JUDGE; FLOYD; JEFFS, 2008; ROCHA et al., 2008, ROCHA; DELIBERATO, 2009a, 2009b; PELOSI, 2006, 2008, 2009; GALVÃO FILHO, 2009; SAMESHIMA; DELIBERATO 2009a; SAMESHIMA et al., 2009).

O uso da tecnologia assistiva na educação vai além de simplesmente auxiliar o aluno a realizar tarefas, pois por meio dela é possível encontrar maneiras do aluno ser e atuar de forma construtiva no seu processo de aprendizagem (SUÀREZ et al., 2003; BERSCH, 2006; PELOSI, 2006, 2008).

A tecnologia assistiva surge, para a pessoa com deficiência, em muitos casos como um elemento essencial que estimula a construção de novos caminhos e possibilidades para o seu aprendizado e desenvolvimento. À medida em que se situa como instrumento mediador, a tecnologia assistiva disponibiliza recursos para participação de pessoas com deficiência, pois permite que ela interaja, relacione-se e possa competir em seu meio com ferramentas mais poderosas (PERES, 2003; SORO-CAMATEZ, 2003).

Pelosi (2006), discutiu que o sucesso do processo de inclusão está estreitamente relacionado á possibilidade de reconhecer e aceitar as diferenças. Isso não significa ignorá-las e colocar as crianças com necessidades educacionais especiais em sala de aula regular e esperar que as mesmas aprendam pela proximidade com seus colegas, mas sim oferecer os recursos necessários para que a criança aprenda. A tecnologia assistiva favorece a aprendizagem e o desenvolvimento da criança com deficiência, pois permite que ela participe com maior eficácia nas atividades de sua rotina em seu ambiente natural (JUDGE; LAHM, 1998, LANGONE; MALONE; KINSLEY, 1999; SORO-CAMATS; 2003; MISTRETT et al., 2005; DELIBERATO; 2007, 2009a).

Os documentos nacionais que regem a educação no Brasil, também enfatizam que na proposta da educação especial a tecnologia assistiva tem a função de atender às especificidades dos alunos com necessidades educacionais especiais e os habilitar funcionalmente nas atividades escolares. Em relação à educação inclusiva a tecnologia assistiva está inserida com o objetivo de conduzir à promoção da inclusão de todos os alunos na escola. Portanto, o espaço escolar deve ser estruturado como aquele que oferece os recursos, serviços e estratégias de tecnologia assistiva (BRASIL, 2006).

Pelosi (2008, 2009), exemplificou o uso de recursos e serviços no ambiente escolar: o recurso é o equipamento utilizado pelo aluno que permite que ele realize uma tarefa; e o serviço de tecnologia assistiva na escola é aquele que busca resolver os problemas funcionais 
do aluno, encontrando alternativas para que ele participe e atue ativamente nas várias atividades deste contexto, é a ação de avaliar, indicar, treinar e acompanhar o recurso de tecnologia assistiva na escola.

A literatura internacional também vem discutindo os recursos e serviços de tecnologia no ambiente escolar. Neste contexto Judge, Floyds e Jeffs (2008), tiveram como objetivo descrever uma lista de recursos da tecnologia assistiva para uso de crianças e jovens com deficiências, que podem ser facilmente adquiridos e utilizados por profissionais da educação. Entre os recursos descritos são encontrados:

1) Recursos de posicionamento: são utilizados para facilitar a exploração do ambiente, tem-se como exemplo os assentos, mesas e balcões adaptados, coletes e cintos, cunhas, rolos, cadeiras de rodas, cadeiras de canto, cadeiras e mesas reguláveis;

2) Recursos de comunicação alternativa e suplementar: gravador de mensagens, computador, programas de software como Boardmaker (Mayer-Johnson), pranchas de comunicação, fotografias, calendários, listas e tabelas de horários. Estes recursos facilitam a comunicação tanto na sala de aula quanto no dia a dia.

3) Materias escolares: lápis e tesouras adaptadas, pranchas inclinadas, softwares interativos, acionadores, atividades pedagógicas adaptadas, brinquedos e jogos adaptados, interruptores de pilhas e baterias.

4) Adaptações para computador: tela sensível ao toque, mouses e teclados adaptados (JUDGE; FLOYD; JEFFS , 2008).

Entre os recursos descritos anteriormente é possível identificar os de alta tecnologia como computadores e softwares específicos, como também recursos de baixa tecnologia. Os recursos de baixa tecnologia podem ser confeccionados pelo professor a partir de materiais que fazem parte do cotidiano escolar (BRASIL, 2006).

Os serviços de tecnologia na escola podem ser prestados por vários profissionais, das áreas da educação e saúde, pois este serviço tem um caráter multidisciplinar, assim terapeutas ocupacionais, fonoaudiólogos, educadores, fisioterapeutas e psicólogos poderão contribuir com engenheiros e outros profissionais no trabalho de identificação do recurso de tecnologia assistiva mais indicado (PELOSI, 2008, 2009; DELIBERATO, 2009).

Barnes e Turner (2001), relataram que a tecnologia assistiva aplicada à escola envolve diversas atuações como: 
1) a comunicação alternativa e ampliada;

2) a mobilidade alternativa, realizada por meio da utilização de andadores e pranchas de deslocamento, cadeiras de rodas manuais e motorizadas;

3) o posicionamento adequado na carteira da escola, estabilizadores ou cadeira de rodas;

4) o acesso ao computador e as suas adaptações como o teclado adaptado, softwares especiais, mouses alternativos;

5) adaptações de atividade de vida diária como higiene e alimentação, as adaptações das atividades pedagógicas;

6) as adaptações para a utilização de diversos ambientes na escola como, laboratórios, sala de artes;

7) a acessibilidade e adaptação do ambiente com rampas e banheiros adaptados;

8) o transporte adaptado;

9) adaptações de equipamentos de lazer e recreação.

No Brasil, o Documento Atendimento Educacional Especializado - Deficiência Física, publicado pelo MEC em 2007 (BRASIL, 2007), tem por objetivo oferecer orientações a fim de facilitar o acesso à tecnologia assistiva no cotidiano escolar de alunos com deficiência física.

Este documento citou a tecnologia assistiva com os objetivos de viabilizar ao aluno com deficiência física a participação e a realização de tarefas acadêmicas e também a adequação do espaço escolar. Para atingir estas metas, o documento propôs a atuação relacionada a áreas de conhecimento ou ações práticas:

1) Comunicação Alternativa e Suplementar: pretende atender as necessidades de alunos com dificuldades de fala e de escrita;

2) Adequação dos materiais didáticos pedagógicos: tem como objetivo atender às necessidades dos alunos e ampliar as sua funcionalidade durante as atividades escolares. Como exemplo é possível citar os engrossadores de lápis, quadro magnético com letras imantadas, tesouras adaptadas, entre outros;

3) Desenvolvimento de projetos em parceria com profissionais da arquitetura, engenharia, técnicos em edificações a fim de promover a acessibilidade arquitetônica; 
4) Adequação de recursos da informática: teclado e mouse adaptados, ponteira de cabeça, programas especiais, acionadores, entre outros;

5) Uso de mobiliário adequado: os professores especializados devem solicitar à Secretaria de Educação adequações de mobiliário escolar, conforme especificações de especialistas na área: mesas, cadeiras, quadro, entre outros, bem como os recursos de auxílio à mobilidade: cadeiras de rodas, andadores, entre outros (BRASIL, 2007).

Outro aspecto importante discutido na área de tecnologia assistiva é a adaptação do ambiente frente à diversidade de habilidades e necessidades do deficiente. Apesar de reconhecer que crianças com deficiência apresentam necessidades individuais, é fundamental que os ambientes que elas circulem estejam equipados por ferramentas que deem suporte às suas diversidades. O reforço de suas habilidades com a utilização da tecnologia assistiva é uma valiosa estratégia de integração e ampliação da aprendizagem, pois as crianças têm o desejo natural de explorar os seus ambientes (JUDGE; FLOYD; JEFFS, 2008).

Neste contexto de preocupação com a adaptação do ambiente Edyburn (2000), reforçou a importância do recurso da tecnologia assistiva para a criação de adaptações do meio ambiente (escolar, familiar e social). Além dessa questão, discutiu que o recurso pode e deve ser inserido no ambiente a partir de um planejamento. O professor pode, após o planejamento, estabelecer as necessidades de adaptação do ambiente, tarefa acadêmica e do conteúdo proposto (ROSELL, 2003; DELIBERATO, et al. 2007; DELIBERATO, 2009a, DELIBERATO; SAMESHIMA, 2009a; PONSONI et al., 2009).

A tecnologia assistiva tem sido utilizada no contexto escolar para criar ambientes mais propícios à aprendizagem, para isto seus serviços, recursos e estratégias possibilitam aos alunos ampliar suas habilidades e desenvolver um sentimento de controle sobre o processo de aprendizagem (CONNERS; JOHNSON, 2001; DELIBERATO; 2009a, 2009b; ROCHA; DELIBERATO, 2009b).

Para Rocha e Deliberato (2008), a tecnologia assistiva no contexto escolar vem sendo considerada como um recurso estratégico e direcionado que proporciona a adaptação de atividades, a modificação do ambiente físico ou ainda a compensação de habilidades de desempenho para a execução de uma tarefa.

Um aspecto importante a ser considerado é a formação dos professores de crianças com deficiência em relação ao uso da tecnologia assistiva. Neste contexto Judge e Simms (2009), realizaram um estudo nacional com o objetivo de analisar documentos referentes aos conteúdos dos cursos para formação de professores da educação especial. Os resultados 
indicaram que aproximadamente $33 \%$ dos programas de graduação, $28 \%$ dos programas de especialização, e menos de $25 \%$ dos programas de mestrado tinham em seu conteúdo disciplinas para a formação em tecnologia assistiva. Esses números segundo os autores apontam para a necessidade de medidas a fim de ampliar o número de cursos para formação de professores que ofereçam em seu currículo conteúdos de tecnologia assistiva. Os pesquisadores concluíram que estes resultados têm implicações importantes na prática futura desses professores em relação à tecnologia assistiva e ao aluno com deficiência.

Em uma pesquisa de revisão bibliográfica na tecnologia assistiva Copley e Ziviani (2004), realizaram uma análise dos estudos para identificar os obstáculos identificados no uso dos recursos nas escolas. A partir dos resultados os autores identificaram que as barreiras encontradas incluíram a falta de uma adequada formação dos profissionais, a falta de uma equipe de apoio, as atitudes negativas das pessoas em relação à tecnologia assistiva, a avaliação e os processos de planejamento inadequados, financiamento insuficiente, dificuldades de gestão e aquisição de recursos, e limitações de tempo. Os pesquisadores propuseram uma equipe de assistência modelo para avaliação e planejamento do uso dos recursos e estratégias de tecnologia assistiva, a fim de otimizar a execução dos objetivos educacionais de crianças com deficiências múltiplas. Esta equipe pode ajudar a orientar o uso da tecnologia assistiva nas escolas e promover melhor independência funcional e participação do aluno.

No Brasil, um estudo realizado por Pelosi (2008), teve como objetivo formar profissionais das áreas da saúde e educação em tecnologia assistiva a fim de formar uma equipe de apoio, e também acompanhar esta equipe que realizou a ação conjunta nas escolas. O modelo do estudo utilizado foi o da pesquisa ação, para isto envolveu 46 professores, 78 terapeutas ocupacionais, 9 fonoaudiólogas e 162 alunos com necessidades educacionais especiais. Os instrumentos de pesquisa incluiram questionários, entrevistas semi-estruturadas, registros dos participantes, fotografias, filmes e o caderno de campo da pesquisadora. Os resultados deste estudo demonstraram que a ação conjunta e a parceria da Saúde e Educação proporcionaram situações de aprendizagem favoráveis à inclusão escolar. A introdução da equipe de apoio composta por terapeutas ocupacionais, fonoaudiólogos e professores itinerantes contribuiu para a sensibilização e mudança de atitude dos professores, pois trouxe para dentro da escola, esclarecimentos a respeito dos alunos, recursos e estratégias que potencializaram suas habilidades. Também foi constatado que os profissionais da saúde se aproximaram da realidade da escola e perceberam a necessidade de transformação de suas ações no processo de reabilitação, tornando-a mais direcionada à inclusão escolar. 
No processo de utilização da tecnologia assistiva na escola as parcerias entre os profissionais, familiares e os usuários são desejáveis, pois podem otimizar a identificação de soluções adequadas para o uso de seus recursos e serviços junto aos alunos com deficiência. (PARETTE; BROTHERSON; HUER, 2000; LAHM; SIZEMORE, 2002, PELOSI, 2008; DELIBERATO, 2009a, 2009b; ROCHA; DELIBERATO, 2009a, 2009b; SAMESHIMA; DELIBERATO, 2009a, 2009b)

Okolo e Bouck (2007), realizaram outra pesquisa de revisão bibliográfica a fim de identificar os estudos a respeito da tecnologia assistiva entre o ano de 2000 a 2006. O estudo teve dois objetivos: verificar a utilização da tecnologia assistiva junto a alunos com deficiência e refletir sobre o conhecimento que está sendo produzido por pesquisadores que estão analisando estas questões. Foram levantados 122 estudos, e após análise dos dados foi constatado que a maioria dos estudos tiveram como participantes alunos que utilizavam recursos da comunicação alternativa e suplementar. Alunos com deficiências físicas e sensoriais, que são grandes beneficiários dos recursos de tecnologia assistiva raramente foram o foco desses estudos.

Ainda neste estudo foi constatado que alunos de 0 a 4 anos foram incluídos em mais de $10 \%$ dos estudos revisados, o que sugere que a tecnologia assistiva representa um importante papel na educação de crianças pré-escolares. Outro dado importante é a prevalência de estudos que enfatizam a formação de professores e outros profissionais, este dado é promissor, pois a literatura aponta que a falta de conhecimento dos professores, profissionais, e a baixa participação da família são os principais obstáculos para a utilização da tecnologia assistiva.

A comunicação alternativa e suplementar é uma área da tecnologia assistiva em pleno desenvolvimento no Brasil. Referente à literatura desta área é possível identificar pesquisas internacionais e nacionais com a preocupação de incluir os sistemas de Comunicação Alternativa e Suplementar nas escolas (VON TETZCHENER, 2003, 2009; VON TETZCHENER et al., 2005; PELOSI, 2003, 2008; DELIBERATO, 2009a; SAMESHIMA, DELIBERATO; 2009a)

Um estudo realizado por McDonald et al. (2008), teve como objetivo fornecer equipamentos de comunicação suplementar e alternativa para alunos que não foram capazes de falar, a fim de facilitar o seu acesso à educação. Para contemplar estes objetivos foram realizadas avaliações individuais de crianças e posteriormente traçadas três metas a serem alcançadas que variaram de acordo com as necessidades especificas de cada uma delas. Após 6 meses de intervenção foram reavaliadas 60 crianças, com idades compreendidas entre os 3 e 
os 18 anos a fim de analisar se elas tinham alcançado, parcialmente alcançado ou não alcançados cada meta. Os resultados demonstraram que $63 \%$ das metas não foram alcançadas, e $36 \%$ foram alcançados. Os pesquisadores concluíram que os recursos de tecnologia assistiva ajudaram as crianças com necessidades comunicação suplementar e alternativa dentro da educação. No entanto, apenas um terço das metas traçadas foi alcançado. As razões para isto incluem fornecimento inadequado de recursos, as exigências de habilidades para o uso dos recursos e a falta de serviços e estratégias adequadas. Com estes resultados foi possível propor a necessidade de uma avaliação específica e trabalho adequado às necessidades individuais de cada criança.

Johnston e Evans (2005) realizaram um estudo de revisão bibliográfica com a finalidade de discutir as variáveis que poderiam influenciar a escolha de um indivíduo a utilizar ou não a tecnologia assistiva. Os autores utilizaram em seu trabalho a Teoria da Correspondência como base para a hipótese de que quando um indivíduo tem a oportunidade de escolher entre duas ou mais possíveis respostas, a resposta que o indivíduo percebe como mais eficiente será escolhida. Os resultados revelaram que pode ser viável a manipulação das variáveis com o objetivo de modificar o uso do recurso de tecnologia assistiva e aumentar a eficiência global e a sua eficácia durante as intervenções, considerando as respostas de cada indivíduo. Os autores concluíram neste estudo que as adaptações realizadas na maioria dos estudos revisados proporcionaram uma igualdade de oportunidades, fazendo com que o indivíduo conseguisse maior independência na manipulação dos objetos desejados.

Galvão Filho (2009) estudou o processo de apropriação e uso da tecnologia assistiva por escolas públicas de Ensino Básico, tecnologia essa necessária para a inclusão de alunos com deficiência em suas salas de aula. O estudo foi realizado por meio de entrevistas com gestores, professores, coordenadores pedagógicos e responsáveis por salas de recursos de quatro escolas. Os resultados constataram avanços e conquistas verificados no processo de apropriação da tecnologia assistiva pelas escolas estudadas, e também as dificuldades e obstáculos encontrados nesse processo. As principais barreiras encontradas pelos profissionais se referem à necessidade de ações mais efetivas das gestões centrais das redes educacionais públicas às quais pertencem, e políticas públicas consistentes e sistemáticas que favoreçam uma maior agilidade e eficácia no processo de apropriação e uso da tecnologia assistiva necessária para a inclusão escolar de alunos com deficiência. A partir dos dados obtidos, o pesquisador apresenta possibilidades concretas de novos horizontes, perspectivas e políticas públicas que favoreçam e viabilize o avanço nesses processos, tal como a implantação de Centros de Referência em Tecnologia Assistiva e Acessibilidade, e a construção de ambientes 
telemáticos de aprendizagem favorecedores de práticas educacionais escolares mais inclusivas e compatíveis com as necessidades da sociedade.

Diversas pesquisas também vem discutindo sobre estratégias que possam efetivar a utilização da tecnologia assistiva na escola. Neste contexto Bersh (2006, 2009), discutiu ser necessário buscar, com criatividade, uma alternativa para que o aluno realize o que deseja ou precisa, de forma a valorizar o seu jeito de fazer e assim aumentar suas capacidades de ação e interação a partir de suas habilidades. A tecnologia assistiva na escola pode criar novas alternativas para a comunicação, escrita, mobilidade, leitura, brincadeiras, artes, utilização de materiais escolares e pedagógicos, exploração e produção de temas através do computador.

Ao pensar na implementação da tecnologia assistiva na escola é necessário conhecer o aluno, sua história, suas necessidades e desejos, bem como identificar quais são as necessidades do contexto escolar, incluindo seu professor, seus colegas, os desafios curriculares, as tarefas exigidas no âmbito coletivo da sala de aula e as possíveis barreiras encontradas que lhe impedem o acesso aos espaços da escola ou ao conhecimento (PELOSI, 2003, 2006, 2008; ROSSELL, 2003; DELIBERATO; 2004, 2009; BERSH, 2008; ROCHA DELIBERATO, 2009a, 2009b, SAMESHIMA; DELIBERATO,2009a).

O processo de implementação da tecnologia assistiva envolve sequência procedimentos. No final da década de 80 Trombly (1989), com o intuito padronizar a adaptação de uma atividade na área da Terapia Ocupacional, estabeleceu etapas que poderiam colaborar neste processo:

1) Análise da tarefa: é necessário identificar as habilidades do indivíduo relacionadas ao ambiente em que ele se encontra;

2) Identificar o problema;

3) Reconhecer os princípios de compensação dos elementos a serem adaptados;

4) Realizar propostas de soluções que envolvam as sugestões do profissional e a colaboração do indivíduo sua família e/ou seu professor;

5) Conhecer recursos alternativos para a solução dos problemas;

6) Realizar o treinamento com o objetivo do uso funcional da adaptação;

7) Verificar periodicamente a adaptação avaliando a necessidade de mudanças (TROMBLY, 1989).

Também preocupados com a sistematização do uso da tecnologia assistiva com alunos com deficiência no contexto escolar, Manzini e Santos (2002), descreveram as etapas 
para implementar a tecnologia assistiva na escola. A seguir a Figura 1 representa o percurso estabelecido pelos autores:

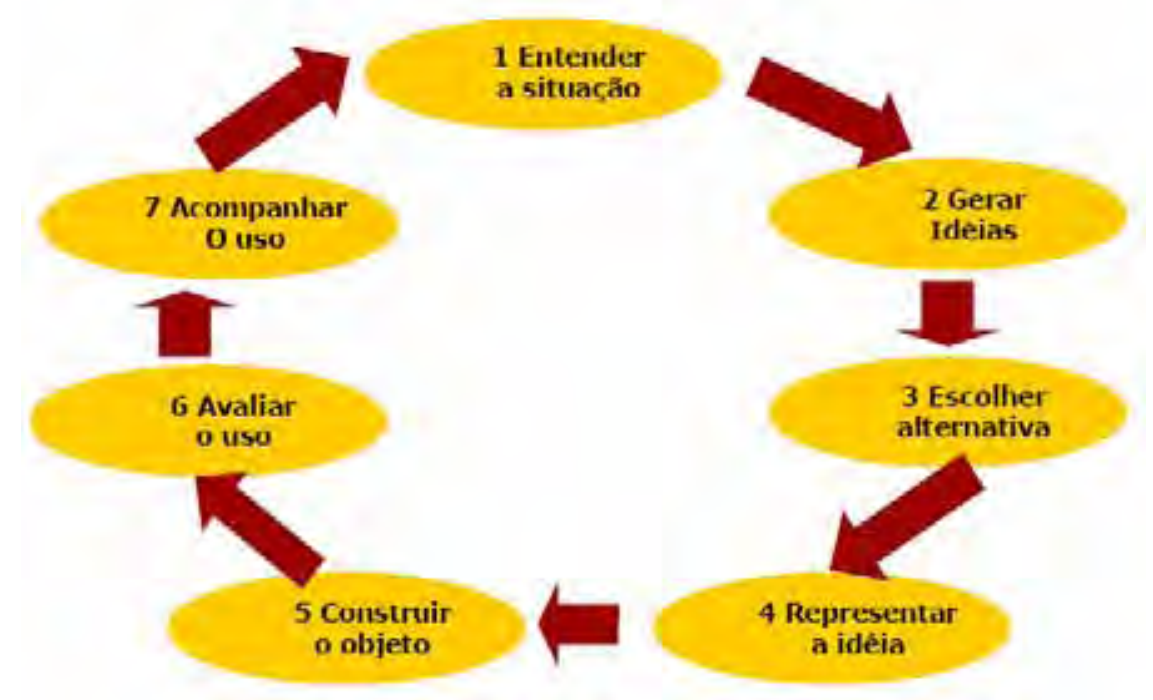

Figura 1 - Fluxograma para desenvolvimento de tecnologia assistiva na escola (MANZINI; SANTOS; 2002).

Os autores estabeleceram as etapas do processo de implementação da tecnologia assistiva por meio do fluxograma acima e definiram cada etapa, descritas a seguir:

1)Entender a situação que envolve o estudante: para isto é necessário escutar seus desejos, identificar as características físicas, psicomotoras e comunicativas, observar a dinâmica do estudante no ambiente escolar e reconhecer o contexto social;

2) Gerar idéias: para isto é necessário conversar com os usuários, buscar soluções, pesquisar materiais que podem ser utilizados e pesquisar alternativas para a confecção do objeto;

3)Escolher a alternativa viável: devem-se considerar as necessidades a serem atendidas e a disponibilidade de recursos materiais e custos para a confecção do recurso;

4) Representar a idéia (desenhos, modelos e ilustrações): nesta etapa devem-se definir os materiais e as dimensões do objeto (forma, medida, peso, textura, cor);

5) Construir o objeto para experimentação: é necessário experimentar o recurso na situação real de uso, ou seja, observar o aluno utilizando o material no contexto proposto;

6) Avaliar o uso do objeto: deve-se avaliar se o recurso atendeu o desejo da pessoa no contexto determinado e verificar se facilitou a ação do aluno e do educador; 
7) Acompanhar o uso: verificar se as condições do aluno mudam com o passar do tempo e se a necessidades de alguma adaptação no recurso (MANZINI e SANTOS, 2002).

As etapas definidas pelos autores podem contribuir aos professores e demais profissionais critérios para o uso adequado de um recurso de baixa ou alta tecnologia para o aluno com deficiência em diferentes ambientes, principalmente no contexto escolar (SOROCAMATS, 2003; BASIL, 2003; BERSH, 2008; PELOSI, 2003, 2008, 2009).

\subsection{Deficiência Física e Educação Infantil}

A forma de educar as crianças em nossa sociedade está em processo de transformação. Em um passado recente as crianças viviam sua infância nos quintais e nas ruas, sempre sobre a responsabilidade dos pais. Hoje, cada vez mais, as crianças frequentam creches e préescolas.

No ano de 1996, a Lei de Diretrizes e Bases da Educação Nacional tornou visível a importância da Educação Infantil, e desde então passou a ser considerada como primeira etapa da Educação Básica. A Educação Infantil atendia crianças de 0 a 6 anos, e o trabalho pedagógico têm como objetivos atender às especificidades do desenvolvimento das crianças dessa faixa etária e contribuir para a construção e o exercício de sua cidadania (BRASIL, 1996).

Recentemente a Lei 11.274, de 6 de fevereiro de 2006, alterou a redação da Lei no 9.394, de 20 de dezembro de 1996, que estabeleceu as diretrizes e bases da educação nacional, dispondo sobre a duração de nove anos para o ensino fundamental, com matrícula obrigatória a partir dos seis anos de idade. Em seu artigo $2^{\circ}$ explicita sobre a organização da Educação Infantil que passa a atender crianças de 0 a 5 anos, sendo que para as crianças de 0 a 3 anos será utilizado a nomenclatura de creche e as de 4 e 5 anos pré-escola.

A Educação Infantil tem a finalidade de promover o desenvolvimento integral da criança, em seus aspectos físico, psicológico, intelectual, comunicativo e social, complementando a ação da família e da comunidade (BRASIL, 1996).

Deve-se visualizar os aspectos físicos, psicológicos, intelectuais, comunicativos e sociais como dimensões do desenvolvimento e não como áreas separadas é fundamental, pois 
enfatiza a necessidade de se considerar a criança como um todo, para promover seu desenvolvimento integral e sua inserção na esfera pública. A Lei de Diretrizes e Bases da Educação e também com o Referencial Curricular Nacional para a Educação Infantil enfatiza que a educação infantil tem por finalidade o desenvolvimento integral de todas as crianças, inclusive as com necessidades educacionais especiais, devendo ser realizada em conjunto com as demais crianças, assegurando-lhes o atendimento educacional especializado mediante avaliação e interação com a família e a comunidade. (BRASIL, 1996; BRASIL, 1998).

Os pesquisadores da área têm procurado discutir as necessidades da criança que frequenta a Educação Infantil, neste contexto Mello (2004), enfatizou que a criança necessita ter acesso ao mundo da cultura e da natureza por meio das relações humanas, pelos objetos materiais e não materiais, pelas técnicas, costumes, valores e pela linguagem. A quantidade de acesso à cultura e a sua diversificação interferem diretamente na formação de sua inteligência e personalidade. A criança seleciona o que é de sua necessidade, interesse e desejo, e, além disso, só se apropria desta cultura se for ativa neste processo, para isso necessita internalizar e expressar o que conhece,, vive e experimenta à medida que aprende (MELLO, 2004).

Para Vigotski (1994), o desenvolvimento do indivíduo é resultado de sua relação ativa com o ambiente sócio-cultural, assim o papel social do outro é de fundamental importância, ou seja, o indivíduo aprende e se desenvolve, a partir do convívio com as pessoas e com a cultura em que esta inserida. Nesta perspectiva, no desenvolvimento infantil os adultos e outros parceiros mais experientes são mediadores e criadores de mediações entre a criança e o conjunto da cultura socialmente acumulada a ser apropriada pelo indivíduo.

A educação infantil tem duas importantes funções: o cuidar e o educar. O cuidar surge com o sentido de ajudar o outro a se desenvolver como ser humano, atender às necessidades básicas, valorizar e desenvolver capacidades. O educar tem como significado propiciar situações de cuidado, brincadeiras e aprendizagem orientadas de forma integrada para que possam contribuir para o desenvolvimento das capacidades infantis de relação interpessoal de ser e estar com os outros em atitudes básicas de aceitação, respeito, confiança e o acesso, pelas crianças, aos conhecimentos mais amplos da realidade social e cultural (BRASIL, 1998).

É importante ressaltar a necessidade de oferecer a criança da Educação Infantil os pré requisitos para a leitura e a escrita. Neste contexto Mello (2004), discutiu que a escola de Educação Infantil deve oferecer as crianças pré requisitos para a escrita, assim possibilita as 
condições necessárias para que a aquisição sistemática da escrita no ensino fundamental por sua própria iniciativa e desejo de expressão.

Em seus estudos Vygotsky (1994), discutiu a existência de algumas etapas para a apropriação da escrita pela criança. Este processo se inicia com os gestos indicativos da criança que ainda não fala, mas que comunica seus desejos. Posteriormente a linguagem oral se junta aos gestos, e mais tarde o desenho passa a complementar a sua comunicação. A escrita faz parte da última etapa, se caracterizando como uma linguagem mais complexa, pois necessita que a criança se aproprie de formas mais complexas de expressão.

Os benefícios de um programa de Educação Infantil são indiscutíveis para as crianças, independente de sua condição física, intelectual ou emocional. A participação de crianças com alterações significativas no processo de desenvolvimento e aprendizagem é essencial para valorizar o brincar como forma particular de expressão, pensamento, interação e comunicação infantil, é a socialização das crianças por meio de sua participação e inserção nas mais diversificadas práticas sociais, sem discriminação de espécie alguma (BRASIL, 2003).

Neste contexto de preocupação com a educação infantil, Leontiev (1991), discutiu a necessidade de o professor refletir e selecionar o recurso que favoreça a criança ter uma participação significativa na atividade estabelecida pelo planejamento, fortalecendo com isto a aprendizagem significativa frente ao período de desenvolvimento que o aluno se encontra.

Em uma proposta inclusiva de educação infantil, o currículo e os objetivos gerais são os mesmos para alunos com necessidades educacionais especiais, não sendo necessário um currículo especial, mas sim ajustes e modificações, envolvendo alguns objetivos específicos, conteúdos, procedimentos didáticos e metodológicos que propiciem o avanço no processo de aprendizagem desses alunos (BRASIL, 2006).

$\mathrm{O}$ professor deve planejar cuidadosamente o processo de ensino-aprendizagem e mediar as situações para que todas as crianças, inclusive as com necessidades especiais, tenham acesso à diversidade cultural e com isso possam assimilar os conteúdos e conhecimentos necessários. O professor tem o papel de mediador do processo de aprendizagem, é ele quem estimula as crianças a experimentarem as diferentes formas de conhecimentos.

As atividades planejadas pelo professor devem ser oferecidas através de um processo ativo e significativo por parte da criança para garantir apropriação do conhecimento, e para isso o educador deve intervir provocando situações que de forma espontânea não ocorreriam. É importante destacar que não se trata de uma forma de ensino centrada no professor, mas sim 
uma forma de ensino onde o educador é mediador de uma atividade significativa para criança tornando-se elemento central em seu processo de aprendizagem (MELLO, 1999).

A escola deve propor um arranjo pedagógico com diferentes dinâmicas e estratégias de ensino com objetivo de complementar, adaptar e suplementar o currículo quando necessário. O ambiente escolar, a sala de aula e as estratégias de ensino é que devem ser modificadas para que o aluno possa se desenvolver e aprender.

Em seus estudos Piaget (1964), também apontou a importância do meio para a criança, neste contexto relatou que a inteligência se constrói mediante a troca entre o organismo e o meio; segundo o autor esse mecanismo permite a formação das estruturas cognitivas. Assim as ações das crianças sobre o meio, como fazer coisas, brincar e resolver problemas pode produzir formas de conhecer e pensar mais complexas, combinando e criando novos esquemas, possibilitando novas formas de fazer, compreender e interpretar o mundo que a cerca.

Ao deparar com crianças com a deficiência física é possível identificar uma diversidade de tipos e graus de comprometimento que requerem um estudo sobre as necessidades específicas de cada pessoa. Essas diversidades podem acarretar dificuldades no desempenho funcional dessas crianças, comprometendo suas ações sobre o meio (TROMBLY, 1989, SORO-CAMATS 2003; MANZINI; DELIBERATO, 2004, 2007; BERSH, 2008, PELOSI, 2008).

No Decreto no 3.298 de 1999 da legislação brasileira, é encontrado o conceito de deficiência física:

Art. 4...: - Deficiência Física - alteração completa ou parcial de um ou mais segmentos do corpo humano, acarretando o comprometimento da função física, apresentando-se sob a forma de paraplegia, paraparesia, monoplegia, monoparesia, tetraplegia, tetraparesia, triplegia, triparesia, hemiplegia, hemiparesia, amputação ou ausência de membro, paralisia cerebral, membros com deformidade congênita ou adquirida, exceto as deformidades estéticas e as que não produzam dificuldades para o desempenho de funções.

Por meio do documento do Ministério da Educação (MEC), publicado no ano de 2006 com o título: Salas de Recursos Multifuncionais - Espaço do Atendimento Educacional Especializado, também é possível identificar a definição de deficiência física como:

O comprometimento do aparelho locomotor que compreende o sistema Osteoarticular, o Sistema Muscular e o Sistema Nervoso. As doenças ou lesões que afetam quaisquer desses sistemas, isoladamente ou em conjunto, 
podem produzir grandes limitações físicas de grau e gravidades variáveis, segundo os segmentos corporais afetados e o tipo de lesão ocorrida (BRASIL, 2006, p. 28).

Os participantes deste estudo tiveram o diagnóstico de paralisia cerebral, por isso, neste momento será discutida entre todas as possibilidades de deficiência física essa patologia.

A paralisia cerebral vem sendo estudada há vários anos, sendo citada pela primeira vez por Little em 1843, como uma encefalopatia crônica da infância. Em 1897 Freud sugeriu a expressão paralisia cerebral definindo um grupo de crianças com transtornos motores secundários a uma lesão no Sistema Nervoso Central (ROTTA, 2002).

Bobath (1982), foi considerado um dos grandes estudiosos da área e definiu a paralisia cerebral como uma desordem da postura e do movimento que acomete o cérebro imaturo e não é progressiva.

É evidente que além das limitações motoras, que são os sinais mais evidentes na paralisia cerebral, existem outras características importantes que interferem no desenvolvimento. Neste contexto Souza (2005), definiu a paralisia cerebral como:

Um grupo de desordens do movimento e da postura, causando limitação de atividades, que são devidas a alterações não progressivas que ocorreram no cérebro fetal ou infantil. As desordens motoras da paralisia cerebral frequentemente estão acompanhadas por alterações sensoriais, na cognição comunicação, percepção, comportamento e/ou crises convulsivas. (SOUZA, 2005. p.51)

A paralisia cerebral é causada por uma lesão no cérebro que ocorre antes dos dois anos de vida (NOETZEL; MILLER, 1998; SCHWARTZMAN, 2004), e, dependendo da localização e extensão da lesão diferentes partes do corpo podem ser afetadas (GIANNI, 2003, 2005).

As principais causas da paralisia cerebral estão associadas a fatores genéticos, como por exemplo a má formação do sistema nervoso central, infecções congênitas (rubéola, toxoplasmose, sífilis, herpesvírus), encefalopatia hipôxico isquêmica, encefalopatia neonatal, encefalopatia bilirrubínica, meningoencefalites, traumas crânio encefálicos e semi afogamentos (PIOVESANA, 2002; GIANNI, 2003, 2005; SCHWARTZMAN, 2004)

Quanto à classificação clínica da paralisia cerebral Gauzzi e Fonseca (2004), identificaram controvérsias na literatura. Neste contexto entre as formas clínicas de manifestação da paralisia cerebral podem ser encontradas: espástica, discinética (atetóide, 
coréico, distônico), atáxica e mista (GIANNI 2003, 2005, 2010;). Alguns autores acrescentam a essa classificação a forma hipotônica (GAUZZI; FONSECA, 2004).

A paralisia cerebral do tipo espástica é caracterizada pela lesão do sistema piramidal que provoca o aumento do tônus muscular (hipertonia), comumente pela espasticidade caracterizada pelo aumento dos reflexos tendinosos e resistência ao estiramento muscular rápido. Neste tipo de paralisia cerebral é muito frequente a instalações de deformidades osteoarticulares (GAUZZI; FONSECA, 2004; GIANNI, 2003, 2004, 2010).

O tipo discinética é resultante da lesão do trato extrapiramidal frequentemente relacionado aos gânglios da base. A principal característica são os movimentos involuntários, a dificuldade da criança em manter a postura, executar movimentos voluntários e coordenar os movimentos automáticos. Estas crianças geralmente convivem bem com a persistência dos reflexos primitivos, muitas vezes utilizando-os funcionalmente. Podem ser divididos em dois grupos: a coreoatetósica, que se subdivide em atetóse caracterizada por movimentos lentos, suaves e uniformes presentes na parte distal dos membros e a coréia vem acompanhada de movimentos rápidos, arrítmicos e amplos na região proximal dos membros; e a forma distônica, menos frequente e classificada por movimentos amplos e fixos, menos intensos, acarretando a posturas bizzaras (GAUZZI; FONSECA, 2004; SCHWARTZWAN, 2004).

Quanto ao tipo atáxica é decorrente da lesão do cerebelo ou vias cerebelares, e é caracterizado pela presença de incoordenação motora, tremor intencional, hipotonia, dismetria e marcha instável de base alargada. (GAUZZI; FONSECA, 2004; GIANNI, 2003, 2004, 2010).

A paralisia cerebral do tipo hipotônica é uma forma mais rara, caracterizada pela diminuição do tônus muscular (hipotonia) que persiste após os dois anos (GAUZZI; FONSECA, 2004; SCHWARTZMAN, 2004).

O tipo misto se caracteriza por lesões difusas e de grande extensão, apresentando sintomas associados a mais de um tipo clínico (GIAN NI, 2003, 2004, 2010).

Além das diferentes formas de manifestações clínicas, ainda pode ser classificada a criança com paralisia cerebral em relação à sua distribuição topográfica. A literatura também apresenta diferenças na classificação, porém neste trabalho serão utilizadas as referências segundo Gianni (2003, 2005), que divide em três grupos: a hemiparesia onde a lesão se apresenta em apenas em um dos hemisférios, determinando o comprometimento de um hemicorpo; a diparesia que se caracteriza pelo comprometimento dos quatro membros, com predomínio dos inferiores, frequentemente se relaciona a lesões isquêmicas no sistema nervoso do recém-nascido pré termo; e a tetraparesia onde a comprometimento simétrico nos 
quatro membros acarretando em uma maior dificuldade do uso funcional de membros superiores e da aquisição de deambulação, geralmente é causada pelo insulto hipóxico isquêmico do recém-nascido a termo.

Em relação à distribuição topográfica, embora o uso do prefixo paresia signifique paralisia menos acentuada, a literatura utiliza também o termo plegia indistintamente em sua rotina, não estabelecendo diferenciação na gravidade do problema (GAUZZI; FONSECA, 2004).

É fundamental que os professores conheçam a diversidade e a complexidade dos diferentes tipos de deficiência física, desta forma conseguirão utilizar estratégias de ensino que desenvolvam o potencial do aluno. De acordo com a limitação física apresentada é necessário utilizar recursos didáticos e equipamentos especiais e assim viabilizar a participação do aluno nas situações práticas vivenciadas no cotidiano escolar; desta forma o aluno pode participar deste contexto com autonomia e passa a otimizar suas potencialidades e transformar o ambiente em busca de uma melhor qualidade de vida (BRASIL, 2006).

Mello (2007) apontou quatro indicadores que compõem o conjunto do fazer educativo e a experiência de aprendizagem das crianças na Educação Infantil: o ambiente, ou seja, a forma como se organiza e se utiliza o espaço; o tempo, ou seja, a forma como é gerido o tempo que a criança passa na escola; as atividades nas quais as crianças se envolvem e que propiciam aprendizado e desenvolvimento das funções psíquicas superiores e as relações que se estabelecem na escola, os adultos entre si, as crianças entre si e os adultos com as crianças. A criança com deficiência física pode estar prejudicada em todo este conjunto, situação que interfere diretamente no seu processo de aprendizagem.

Em relação ao ambiente, as limitações motoras dificultam a capacidade da criança em explorá-los de maneira ativa, acarretando dificuldades em se envolver nas atividades pelo seu prazer sensório-motor. Blanche (2000) referiu-se a outros fatores que podem ser tão ou até mais limitadores do que a própria condição motora, os fatores ambientais, decorrentes de barreiras sociais que ocorrem como resultado da imposição dos valores e crenças dos outros, impossibilitando suas interações sociais e às limitações físicas do ambiente, diminuindo o acesso destas crianças à recreação e lazer.

A organização do ambiente escolar tem se constituído, na maioria das vezes, num grande obstáculo para a realização das atividades desenvolvidas durante o tempo em que as crianças permanecem na escola, sendo necessário considerar o papel do ambiente como um dos componentes essenciais para o aprendizado (SITTA, 2008). A criança com deficiência 
física necessita de um espaço que assegure as diferentes de atividades, fundamentais para o desenvolvimento de suas potencialidades e habilidades.

O ambiente propício contemplará as atividades, que deverão ser planejadas pelo professor e por todos os profissionais que atuam direta ou indiretamente com as crianças, organizando o espaço e o tempo (FARIA, 2000).

Os documentos que regem a Educação Infantil apontam ser fundamental a organização do seu espaço, de forma que elimine as barreiras arquitetônicas, adapte os mobiliários, selecione materiais adequados, realize as adaptações nos brinquedos e jogos. Esses procedimentos são instrumentos fundamentais para a prática educativa inclusiva com qualquer criança pequena, e junto à crianças com deficiência física se tornam condições essenciais e prioritárias (BRASIL, 2006).

Mesmo que o ambiente seja adequado à criança com deficiência física, o professor pode ter dificuldades para usar os materiais pedagógicos disponíveis na escola, pois as características motoras, principalmente da criança com paralisia cerebral, podem não permitir um bom desempenho na manipulação desses materiais (AUDI, 2006).

Frente a essa diversidade de habilidades e necessidade motoras será necessário o uso de recursos adaptados para contemplar os objetivos de ensino propostos. Esses materiais nem sempre estarão disponíveis ao professor, sendo necessário identificar e criar recursos que atendam às necessidades individuais destes alunos (MANZINI, 2005).

A literatura vem discutindo a necessidade de garantir o acesso educacional ao aluno com deficiência física, nesse contexto Silva (2010), realizou um estudo com o objetivo de elaborar um instrumento para ser utilizado pelo profissional da educação especial, para a prescrição e adaptação de recursos pedagógicos para o ensino da criança com paralisia cerebral. Os participantes desta pesquisa foram onze estudantes do quarto ano de pedagogia da Habilitação em Educação Especial na área de deficiência física e quatro profissionais também da área da educação especial. Após vários procedimentos para a elaboração deste instrumento a sua quarta versão mostrou-se eficaz para auxiliar o profissional da área de educação especial na avaliação do aluno com paralisia cerebral, suas preferências individuais e as características do ambiente da sala de aula. Os resultados da pesquisa demonstraram que o instrumento é eficiente para direcionar a prescrição ou adaptação de recurso pedagógico para o aluno com paralisia cerebral.

Ao considerar as especificidades do aluno com deficiência física Audi (2006), apontou duas grandes finalidades para adaptar um recurso pedagógico: garantir que o aluno consiga ter acesso à atividade e melhorar o seu desempenho na realização das tarefas. 
A adaptação de recursos na escola deve sempre partir de um objetivo pedagógico diretamente relacionado com o currículo básico escolar. Para isso o professor deve trabalhar com um currículo flexível, ou seja, que direcione o projeto acadêmico, mas aceite mudanças e adaptações em função de determinados contextos escolares (GONZÁLEZ, 2002).

A adaptação de um recurso deve considerar dois fatores: as características motoras, cognitivas, emocionais e sociais da criança e as exigências sociais, pedagógicas, psicológicas e físicas impostas pelo meio (ARAUJO; MANZINI, 2001).

Outro fator importante ao se criar um recurso é que a sua escolha tem de ser individual, pois pode ser completamente diferente mesmo entre alunos com a mesma deficiência, assim ao pensar em dois alunos com paralisia cerebral em sala de aula, um deles pode ter a necessidade de utilizar o computador para a escrita e o outro de um adaptador para o lápis (MANZINI, 2005).

Manzini (2005) considerou fundamental que o aluno com deficiência física participe do processo de escolha dos recursos de tecnologia assistiva que vai utilizar, a decisão da escolha do recurso é bilateral, pois ele deve auxiliar o aluno e o professor. A literatura vem demonstrando que focar os objetivos da intervenção nas expectativas da criança e/ou da família colabora com os resultados positivos a serem alcançados (McGIBBON, 2003).

A adaptação de recursos para crianças com deficiência física no ambiente escolar é uma possibilidade para que questões como o manuseio e aprendizagem possam andar juntas. A adaptação de um determinado recurso escolar, como um brinquedo ou um jogo permite não só que a criança com deficiência física o utilize, mas todo um grupo, em um mesmo espaço e tempo (MANZINI, 2005).

Smith e Ryndak (1999) apontaram que é necessário considerar dois aspectos para o uso de recursos adaptados: o recurso adaptado só deverá ser utilizado quando realmente for necessário e a adaptação não deve ser permanente, necessitando de reavaliações periódicas a fim de perceber a necessidades de modificações.

As características físicas do recurso são essências para o processo de adaptação, o peso do recurso, o tamanho, a forma podem contribuir ou dificultar o movimento, a preensão e a manipulação dos materiais pedagógicos (CRUZ, 2006; CAVALCANTI; GALVÃO, 2007; PAIVA, 2007).

Manzini e Deliberato (2007) discutiram que a necessidade de modificações de um recurso para a criança com deficiência física não podem ser determinadas aleatoriamente, mas é necessário estabelecer critérios com a finalidade de minimizar as dificuldades dos alunos. 
Estudos vêm discutindo os critérios e as possibilidades de recursos e estratégias utilizados com a criança deficiente física considerando as suas características físicas, comunicativas, visuais e cognitivas (MANZINI; SANTOS, 2002; BRUNO, 2005; HELFER; OLIVEIRA; MIOSSO, 2005; AUDI, 2006; REGANHAN, 2006; SAMESHIMA; 2006; GUARDA; 2007; HERCULIANI, 2007; MANZINI; DELIBERATO, 2007; OLIVEIRA, 2007; PAIVA, 2007; VERUSSA, 2009; PONSONI, 2010; SILVA, 2010).

Entre os recursos e estratégias da tecnologia assistiva para criança com paralisia cerebral é essencial as questões referentes ao seu posicionamento. Neste contexto Braccialli, Manzini e Vilarta (2005), apontaram que o posicionamento adequado pode compensar a falta de estabilidade postural e ampliar as habilidades funcionais da criança com paralisia cerebral.

O equipamento para adequação postural deve ser cuidadosamente planejado e confeccionado para atender as necessidades específicas de cada criança, pois o projeto cuidadoso para a elaboração do recurso é capaz de possibilitar um melhor controle e estabilização postural, o controle cervical, o relaxamento da musculatura, o melhor manuseio com os membros superiores e a prevenção de deformidades (RADELL, 1996; BRACCIALLI; MANZINI e VILARTA, 2005; BEUKELMAN; MIRENDA, 2007; BRASIL, 2007; BERSH, 2008; BRACCIALLI et al., 2008).

Além de cadeiras adaptadas, cadeira de rodas, andadores, órteses de posicionamento, alguns recursos mais simples podem ser utilizados concomitantemente pelo professor para melhorar a postura da criança com paralisia cerebral. Neste contexto é possível citar as bandejas ou mesas de apoio, utilizadas junto a cadeiras à altura do tórax podem apoiar os membros superiores e favorecer a sua simetria e o controle de cabeça (RADELL, 1996; BEUKELMAN; MIRENDA, 2007).

Outros recursos como rolos, cunhas, cintos, almofadas e encostos e apoio para os pés podem colaborar para que a criança permaneça com o corpo ergonomicamente alinhado e em condições de participar das atividades adequadamente (RADELL, 1996; BEUKELMAN; MIRENDA, 2005; BRACCIALLI; MANZINI e VILARTA, 2005; BRASIL, 2007; BERSH, 2008; BRACCIALLI et al., 2008).

Apesar de alguns equipamentos proporcionarem melhores condições para a realização das atividades na escola, Braccialli, Manzini e Vilarta (2005), alertaram que oferecer oportunidades para explorar novas posturas é essencial, desta forma a mudança periódica da postura é necessária.

É importante ressaltar que o uso do recurso não garante o sucesso escolar da criança com deficiência física, o bom desempenho do aluno está diretamente relacionado com 
os serviços da tecnologia assistiva e as estratégias utilizadas pelo professor para mediar o uso do recurso (DELIBERATO, 2009; ROCHA; DELIBERATO, 2009a, 2009b, SAMESHIMA; DELIBERATO, 2009b; PELOSI, 2006, 2008).

Os serviços, recursos e estratégias da tecnologia assistiva pode proporcionar oportunidades às crianças com deficiência física de explorar, aprender e interagir com o ambiente. Os recursos da tecnologia assistiva confeccionados para crianças com deficiência física na escola devem ser equipamentos funcionais, mas, sobretudo o professor deve utilizar de estratégias que devem facilitar o seu uso e a interação com os colegas e a faceta lúdica do comportamento infantil (PELOSI, 2006).

As atividades da Educação Infantil podem apresentar diferentes níveis de complexidade, mas a meta do currículo deve ser a mesma para todos os alunos, sendo garantidas as modificações necessárias para promover o aprendizado de todos (CARVALHO, 2000).

É dever da escola assegurar oportunidades iguais a todos os alunos, atendendo suas características pessoais, ou seja, suas diversidades, desenvolvendo ao máximo o seu potencial e a inclusão no grupo. A tecnologia assistiva pode ser utilizada como instrumento facilitador deste processo, pois permite à criança com deficiência física a ampliação de suas habilidades. A introdução da tecnologia assistiva na escola deve abranger as amplas relações que a criança estabelece nesse ambiente, seja com os professores, monitores, amigos ou a família. Deve contribuir para explorar o seu potencial como pessoa, sem criar segregação oculta.

\subsection{O Brincar e a Tecnologia Assistiva na Educação Infantil}

Pesquisadores como Winnicott (1971) e Vygotsky (1994), estudaram o brincar e elaboraram teorias que contribuem para a fundamentação deste tema.

Winnicott (1971), apontou ser necessário estudar o brincar como um fenômeno que ocorre tanto com a criança como com o adulto nas suas formas diferenciadas. Segundo este autor a brincadeira é universal e é própria da saúde, facilita o crescimento, desenvolve o potencial criativo e conduz aos relacionamentos grupais. Ressalta também que quando a criança não é capaz de brincar, há algo errado, fazendo-se necessário proporcionar meios para que ela possa brincar. 
Vygotsky (1989), afirmou que o brincar não pode ser entendido apenas como uma atividade que dá prazer à criança. No entanto, é necessário compreender a brincadeira como atividade que preenche necessidades da criança. No brinquedo a criança cria uma situação imaginária, e em sua evolução temos a mudança da predominância de situações imaginárias para a predominância de regras. O desenvolvimento da criança é dirigido por suas necessidades e interesses, desta forma o brincar é eficaz a fim de promover o avanço de um estágio do desenvolvimento para outro, cria o que Vygotsky chama de zona de desenvolvimento proximal, ou seja, quando brinca a criança está acima das possibilidades da própria idade, imitando os mais velhos nos seus comportamentos.

Baseado em tais teorias é possível identificar que ao brincar a criança constrói conhecimento. As crianças possuem características particulares que fazem com que elas interajam com o meio de uma forma própria, para isto estabelecem desde cedo interações com pessoas próximas e com o meio ao seu redor. No processo de construção do conhecimento, as crianças se utilizam de diferentes formas de linguagens e exercem a capacidade que possuem de terem idéias e hipóteses originais sobre aquilo que buscam descobrir. O conhecimento não se constitui em cópia da realidade, mas sim, fruto de um intenso trabalho de criação, significação e ressignificação (BRASIL, 1998).

Neste trabalho o brincar será entendido como uma ação lúdica que engloba tanto o brinquedo como a brincadeira. O brinquedo contempla o objeto, o suporte para a brincadeira. A brincadeira, portanto, não é o brinquedo, mas o conjunto de estratégias e procedimentos que possibilitam o brincar, independente do objeto.

Ferland (2006) apontou que o brincar representa uma ação subjetiva, onde o prazer, a curiosidade, o senso de humor e a espontaneidade se tocam; esta atitude é possível ser observada através de uma conduta escolhida livremente, da qual não se espera nenhum rendimento específico.

É importante ressaltar que mesmo sem esperar nenhum rendimento específico, o brincar facilita a integração, a sobrevivência, a compreensão da cultura para a flexibilidade de pensamento, a adaptação, o aprendizado, a resolução de problemas, a aquisição de idiomas, a integração de informações do ambiente; além do desenvolvimento social, intelectual, emocional e de habilidades físicas (MOYLES, 2006).

As brincadeiras organizam as sensações do corpo em relação ao meio ambiente, sendo fundamental para o desenvolvimento da criança, pois influência na capacidade de perceber, aprender e organizar estímulos corporais e ambientais, esse processo permite que a criança experimente o prazer de agir, as sensações do mundo, as relações consigo mesma, com as 
pessoas ao seu redor e com o ambiente (TEIXEIRA; ARIGA; YASSUKO, 2003, FERLAND, 2006, MOYLES, 2006).

Zerbinato, Matika e Zerloti (2003), estudaram o brincar e afirmaram que por meio dele a criança percebe o seu potencial de ação no mundo e descobre ser capaz de originar mudanças ao montar, desmontar, misturar, encaixar, e criar, formando e compondo sua inteligência através da prática de desafios, investigação, decisão de problemas e execução das suas funções.

Missuna e Pollock (1991), descreveram que é por intermédio do brincar que as crianças descobrem que elas podem exercer efeito no seu ambiente. O brincar está associado ao prazer, à descoberta, ao domínio, à criatividade e a auto expressão, assim tudo o que as crianças aprendem durante o brincar influencia diretamente na maneira como eles interagem com o mundo real (FERLAND, 2006; MOYLES, 2006).

Segundo Ferland (2006), quando a criança brinca com os outros experimenta a partilha, a rivalidade, a colaboração, o afrontamento; também aprende a encontrar o seu lugar no mundo, tornando-se um ser social, aprendendo também a entrar em contato com os outros e a manter relações com eles.

Bober et al. (2000), realizou um estudo com o objetivo de relacionar o brincar com as atividades que a criança vai realizar no futuro, os resultados demonstraram que as brincadeiras funcionais como brincar de casinha tem correlação direta com atividades funcionais, assim quando a criança brinca imitando as ações de sua mãe, desenvolve competências funcionais para o desempenho de atividades de cuidar da casa.

A literatura aponta a necessidade da criança brincar; nesse contexto Bazyk, Stalnaker e Ekelman (2003), realizaram um estudo com o objetivo de descrever as características das brincadeiras de um grupo de crianças maias. Para isso realizaram um estudo qualitativo, observando 20 crianças de cinco famílias ao longo de um período de duas semanas durante suas ocupações diárias. A análise dos resultados demonstrou que o trabalho dos adultos influencia a ocupação das crianças inteiramente, pois elas participam desta atividade junto com toda a família. Os autores também identificaram que os pais não incentivaram as atividades lúdicas, mas as permitiram desde que não interferissem no trabalho. Com estes resultados os pesquisadores concluíram que o brincar é um processo fundamental para a infância, sendo possível observar que mesmo em países onde culturalmente a principal atividade da criança é o trabalho, elas encontram maneiras de realizarem suas tarefas brincando. 
A literatura tem discutido também a importância do brincar em diferentes ambientes, Saundesr e Goodale (1999), afirmaram que crianças que brincam em diferentes ambientes apresentam melhor desempenho em atividades do dia a dia, ou seja, o contexto pode influenciar o repertório do brincar de crianças e sua capacidade de adaptação nas atividades rotineiras.

Braccialli, Manzini e Reganhan (2004), consideram o brincar uma das atividades fundamentais para o desenvolvimento e a educação da criança. Brincando, a criança tem oportunidade de exercitar suas funções psico-sociais, experimentar desafios, investigar e conhecer o mundo de maneira natural e espontânea.

O Referencial Curricular Nacional para a Educação Infantil (1998) descreveu que a aprendizagem pode ocorrer através das brincadeiras provenientes de situações pedagógicas intencionais ou aprendizagens orientadas pelos adultos. É importante ressaltar, que essas aprendizagens, de natureza diversa, ocorrem de maneira integrada no processo de desenvolvimento infantil (BRASIL, 1998).

Nesse meio o professor estrutura o campo das brincadeiras na vida das crianças, por meio da oferta de brinquedos ou jogos, da delimitação e arranjo dos espaços e do tempo para brincar (BRASIL, 1998).

Por meio do brincar os professores podem observar e compor uma visão dos processos de desenvolvimento das crianças em conjunto e de cada uma em particular, registrando suas capacidades de linguagens, sociais e os recursos afetivos e emocionais que dispõem (BRASIL 1998).

Com o objetivo de analisar o brincar da criança Ferland (2006), descreveu cinco componentes a serem observados nesta atividade: (1) o sensorial que é a vontade de olhar, tocar e pegar que os brinquedos provocam na criança; (2) o motor que é caracterizado pelos diferentes tipos de movimentos e reações de proteção, praticados durante a brincadeira; (3) o cognitivo representado pela compreensão do funcionamento dos brinquedos e brincadeiras; (4) o afetivo que é a expressão, a reação à frustração e ao prazer imediatos; e (5) o social simbolizado pela capacidade de dividir brinquedos, comunicar idéias, levar em conta a opinião do outro e esperar a vez.

Através destas considerações teóricas é possível destacar que o brincar é fundamental para a criança, pois fornece estratégias de desenvolvimento cognitivo, físico e social, necessários não somente à criança típica, mas também às crianças com necessidades especiais. 
Ao relacionar a criança com deficiência física e o brincar Blanche (2002), discutiu que as limitações motoras poderiam ser um obstáculo para a participação da criança nessa atividade. A dificuldade da criança em acessar o ambiente de forma ativa e, consequentemente de explorá-lo, limita o seu potencial de ingressar espontâneamente em uma brincadeira. Assim, as crianças com deficiência física podem apresentar dificuldades em participar das brincadeiras pelo seu próprio prazer sensório motor, esse fato restringe o posterior desenvolvimento da coordenação motora, da percepção e da cognição. A criança pode vir a ter consequências não somente motoras e sensoriais, mas também no desenvolvimento emocional e principalmente das relações sociais (LORENZINI, 2002; FERLAND, 2006).

Ainda como obstáculo para o brincar, Gralewicz (1973), apontou que as crianças com deficiência física brincam menos que as crianças típicas, pois segundo o autor passam grande parte de seu tempo em terapias. Contribuindo também para estes dados Rubin (1983), descreveu que essas crianças têm menos parceiros para brincar e dependem mais de adultos para iniciar as brincadeiras.

Apesar das dificuldades da criança com deficiência física em relação ao brincar, Ferland (2006), descreveu que a sequência no desenvolvimento do brincar é a mesma para elas e as crianças típicas, diferenciando-se em relação ao seu conteúdo e a sua forma.

Ao considerar as incapacidades que as deficiências podem acarretar na criança e as possíveis desvantagens que podem estar presentes em seu cotidiano, Winnicott (1971), referenciou em suas pesquisas que a brincadeira é universal e pertence à saúde, e se pertence à saúde, nesse brincar podem-se encontrar elementos da individualidade daquele que brinca essenciais como um dos pontos de partida para direcionar intervenções com o objetivo de atender às necessidades de quem o procura.

São inúmeras as barreiras que a criança com paralisia cerebral pode encontrar durante o brincar, entre elas é possível citar a difícil acessibilidade ao brinquedo, a dificuldade de manuseio do brinquedo, as relações interpessoais e as condições ambientais. As privações das experiências do brincar em virtude das barreiras físicas, sociais, pessoais e ambientais podem levar a aquisição de outras incapacidades, de ordem social e emocional, chamadas de deficiências secundárias, relacionadas com as dificuldades de participação social, que podem impedir o desenvolvimento e a vida plena ao aprisionar a pessoa numa rede de barreiras atitudinais (TAKATORI, 2003, FERLAND, 2006; REIS; REZENDE, 2007).

Fronza (2005) destacou que a forma de introduzir o brinquedo à criança é importante, pois em certas situações ele pode apenas ser colocado no ambiente que a criança vai explorar, 
outras vezes, precisa ser apresentado a ela e demonstradas as possibilidades de exploração que este brinquedo oferece.

A tecnologia assistiva pode ampliar as habilidades da criança com paralisia cerebral e possibilitar um melhor desempenho durante o brincar. Esta conduta permite à criança com deficiência física a oportunidade de vivenciar experiências e assim minimizar os impedimentos e participar de ambientes que favoreçam o seu desenvolvimento (OLIVEIRA, 2004).

Takatori (2003) relatou que recorrer à tecnologia assistiva é importante, pois pode permitir à criança dar início ou reiniciar suas atividades para que o objetivo final, o fazer singular e as possibilidades de participação social possam ser alcançados.

Deitz, Swinth e Whithe (2002), realizaram um estudo com o objetivo de adaptar brinquedos para serem operados por interruptores. Após utilizar esses brinquedos com crianças com paralisia cerebral concluíram que o uso destes brinquedos permitiu às crianças desenvolverem conceitos básicos em áreas como tempo de permanência dos objetos, relações de causa e efeito e direcionalidade; as crianças puderam aprender que o ambiente que as cerca pode ser controlado; os brinquedos com interruptores podem ser alternativa viável, permitindo que elas brinquem e explorem de maneira similar à dos seus parceiros que não apresentam deficiência.

Com a proposta de estudar o brincar no contexto escolar Sparling, Walker e Singdahlsen (1984), realizaram um estudo com o objetivo verificar as condições do brincar no ambiente educacional com crianças com paralisia cerebral. Durante a intervenção foram planejadas semanalmente atividades grupais de arte e drama, respeitando a sequência normal do desenvolvimento do brincar: sensório-motor, simbólico e jogo sócio dramático. Os resultados demonstraram uma melhora na maioria das crianças quanto ao desempenho em todas as seis áreas avaliadas, e também em relação à percepção do adulto sobre ao brincar da criança e a importância de não fazer para a criança, mas proporcionar condições no qual possa ocorrer o aprendizado.

A tecnologia assistiva vem a favorecer o acesso de crianças com deficiência física a brincadeiras até então desconhecidas ou impossíveis de serem realizadas por elas. A adaptação de brinquedos atendendo às necessidades e expectativas individuais da criança vêm sendo observada na utilização de adaptadores para a preensão de brinquedos, velocípede com cinto de segurança, uso de softwares para computador, adaptação de mobiliários, brinquedos a pilha com acionadores acoplados, entre outros (REIS; REZENDE, 2007). 
A literatura vem apontando estudos com preocupação em direcionar os serviços, recursos e estratégias para ampliar o brincar da criança com paralisia cerebral, porém Missiuna e Pollock (1991), afirmaram que modificações na comunidade, como parques e playgrounds apropriados à criança com deficiência ainda são raros.

Laufer (2001) realizou uma pesquisa sobre as habilidades da criança com paralisia cerebral e identificou as necessidades em relação ao brincar, em sequência propôs modelos de brinquedos para parque adequados à essa população. Também com essa preocupação, em 2004 a Associação Brasileira de Normas Técnicas (ABNT), publicou através da NBR 14350-1 e a NBR - 14350-2 parâmetros para a construção, adaptação e manutenção de playgrounds.

Outro aspecto que vem sendo discutido pela literatura é a necessidade dos recursos de tecnologia assistiva atenderem às necessidade e desejos de quem os utiliza. Missiuna e Pollock (1991), descreveram algumas questões importantes a serem observadas no brincar da criança com paralisia cerebral antes de implementar a tecnologia assistiva, como por exemplo: a historia do brincar; os tipos de brincadeiras que a criança se envolve, como as atividades, exploração, imitação, construção e dramatização; o estágio do brincar, como por exemplo o desocupado, o solitário, o observador, o associativo, o paralelo, o cooperativo; a progressão do desenvolvimento do brinquedo como funcional, relacional, simbólico ou combinado; a frequência de tempo que a criança brinca, a variedade de brinquedos, a localização física e a oportunidade de interação social.

Em um estudo Besio (2002), considerou que para propor recursos da tecnologia assistiva para facilitar o brincar da criança com deficiência física é necessário considerar alguns aspectos:

1) As habilidades funcionais, motoras, verbais e de comunicação, além da decodificação da linguagem verbal;

2) O nível de complexidade nas suas relações com objetos e sua habilidade na resolução de problemas envolvendo brinquedos;

3) Sua capacidade de imitar uma situação de brincar;

4) Seu potencial de alcançar e lidar com a abstração e o simbólico;

5) O tipo e a qualidade de sua relação com a tecnologia e novos brinquedos;

6) As sugestões e avaliações de profissionais que lidam com a criança em seu dia a dia. 
A partir da atenção a esses aspectos é possível pensar em recursos para a participação da criança com paralisia cerebral nas atividades do brincar.

As discussões teóricas apontam que a estratégia é essencial para mediar o uso do recurso. Nesse contexto Bracegirdle (1992), enfatizou a necessidade de haver uma preocupação em proporcionar condições para que o brincar possa ocorrer, assim não somente brinquedos podem proporcionar um brincar adequado a crianças com paralisia cerebral, mas também a companhia de outra pessoa se torna essencial no processo. No ambiente escolar é fundamental a participação do professor, que vem a ser o mediador do brincar no contexto escolar.

Smith e Cable (1996), descreveram algumas estratégias que podem auxiliar o uso de recursos de tecnologia assistiva durante as brincadeiras com crianças com paralisia cerebral, entre eles é possível citar: proporcionar um ambiente estimulador e que facilite o controle interno, ou seja, a criança deve ter a oportunidade de explorar o ambiente e os brinquedos antes de brincar de fato; construir uma relação de confiança e de trocas com a criança, para isso o brincar deve proporcionar um ambiente de confiança e desafio na medida certa, despertando o sentimento de capacidade na criança diminuindo sua ansiedade; incorporar a atitude de brincar em outros contextos, dessa forma quando a criança já apresenta a habilidade de iniciar a brincadeira, a intervenção deve focar outros componentes de habilidades e desenvolvimento do brincar.

Segundo Reis e Rezende (2007), entre as estratégias fundamentais para mediar o brincar da criança com paralisia cerebral destaca-se o posicionamento adequado, pois favorece o uso das mãos, a melhora do campo visual, facilita a interação com as pessoas ao redor, previne deformidades, evita fadiga muscular, permite o seu conforto e melhora o seu desempenho global. $\mathrm{O}$ posicionamento correto permite à criança aproveitar melhor as pistas do ambiente e assim aumentar sua motivação para brincar. Os recursos de tecnologia assistiva podem auxiliar no posicionamento adequado, pois pode colaborar com a postura, o alcance, a preensão e a locomoção, e assim ampliar o interesse da criança pelo brincar (BRACCIALLI et al., 2008).

Compreender a importância do brincar para o desenvolvimento da criança tem se mostrado uma estratégia fundamental na intervenção junto a crianças com deficiência física considerando as suas singularidades e a necessidade de sua inserção no ambiente. Baseado nestes entendimentos verifica-se a importância do brincar presente no contexto escolar, principalmente na Educação Infantil, pois o brincar exerce uma influência direta em todo processo de aprendizagem. 
Perante a discussão a respeito da importância da tecnologia assistiva para a inserção de serviços, recursos e estratégias para o aluno com deficiência foi possível identificar os seguintes problemas: quais seriam os procedimentos necessários para o professor inserir um recurso de tecnologia assistiva para um aluno com deficiência física? Quais seriam os critérios para identificar, prescrever e confeccionar o recurso de tecnologia assistiva no contexto da Educação Infantil? 


\section{OBJETIVOS}

A preocupação de inserir o aluno com deficiência nas atividades pedagógicas tem sido muito discutida no contexto da tecnologia assistiva. Como já foi apresentado anteriormente as possibilidades de participação do aluno com deficiência física em atividades que contemplam o brincar por meio de recursos adaptados poderia favorecer o desenvolvimento desta criança e facilitar a aquisição de habilidades que são pré-requisitos para a aquisição da leitura e escrita.

Sendo assim o objetivo desta pesquisa foi descrever o processo de prescrição e confecção de recursos de tecnologia assistiva para crianças com paralisia cerebral no contexto da Educação Infantil. 


\section{MATERIAL E MÉTODO}

\subsection{Aspectos éticos}

\subsubsection{Autorização do Comitê de Ética em Pesquisa}

Previamente o projeto de pesquisa foi submetido à avaliação pelo Comitê de Ética em Pesquisa da Faculdade de Filosofia e Ciências da UNESP - Campus de Marília/SP, respeitando as prerrogativas da resolução 196/96 do CONEP que versa sobre ética em pesquisa com seres humanos, tendo recebido parecer favorável, sob o protocolo $\mathrm{n}^{\mathrm{o}}$. 2482/2008 (ANEXO A).

\subsubsection{Termo de Consentimento Livre e Esclarecido}

Os participantes desta pesquisa e seus familiares, responsáveis legais, receberam todas as informações pertinentes ao projeto, como: objetivos, procedimentos de coleta de dados, tempo de duração, resguardo da privacidade do participante e utilização dos dados para fins científicos, tendo sido, assim, convidados a assinar o termo de consentimento livre e esclarecido, confirmando anuência (APÊNDICE A). Foram também realizados os devidos esclarecimentos aos professores dos participantes da pesquisa e, assim, confirmaram anuência nesta pesquisa, por meio do termo de consentimento livre e esclarecido (APÊNDICE B).

\subsection{Critérios de Seleção dos Participantes}

\subsubsection{Critérios de Inclusão dos Participantes}


Foram incluídas no estudo as crianças com paralisia cerebral, matriculadas em salas de aula da Educação Infantil inseridas em serviços de reabilitação, bem como seus professores.

\subsubsection{Seleção dos participantes}

a) Foi encaminhado à Secretaria de Educação de Marília um pedido de autorização para o trabalho de pesquisa, mediante ofício e cópia do projeto, que se pretendia desenvolver no município;

b) Após a autorização da Secretaria de Educação de Marília (ANEXO B), para a realização da pesquisa, foi solicitada uma lista com a relação das crianças com deficiência física matriculadas em escolas de Educação Infantil no município de Marília e suas respectivas escolas. A lista entregue pela secretária continha 17 crianças com deficiência física, destes 6 tinham o diagnóstico de paralisia cerebral. Entre as 6 crianças 2 frequentavam serviços de reabilitação e foram selecionadas para este estudo;

c) A partir desta identificação, foi agendado um encontro com os diretores das escolas de Educação Infantil, a fim de esclarecer sobre o estudo, seus objetivos, seu funcionamento e sobre a aprovação do projeto pela Secretária de Educação;

d) Após autorização da diretora da escola a pesquisadora entrou em contato com os dois professores que tinham alunos com paralisia cerebral matriculados em sua sala de aula, com o objetivo de realizar explicações sobre a pesquisa, seus objetivos e o seu funcionamento. Os professores, que tivessem adesão ao estudo preencheram o Termo de Consentimento Livre e Esclarecido;

e) Em seguida foi realizado contato com os familiares das crianças com a finalidade de realizar os esclarecimentos quanto ao objetivo e funcionamento do estudo. Os familiares que aceitaram participar da pesquisa preencheram o Termo de Consentimento Livre e Esclarecido.

\subsection{Características dos Participantes}


A partir dos critérios de inclusão estabelecidos foram selecionadas duas crianças com deficiência e seus professores. A caracterização dos professores foi obtida durante a coleta de informações por meio da entrevista, enquanto a descrição dos alunos foi obtida no prontuário do serviço de reabilitação e pela utilização de dois instrumentos que avaliaram a classificação motora funcional: o GMFCS (Gross Motor Function Measure Classification System) classifica o nível de função motora grossa (PALISANO et al., 1997); e o MACS (Manual Ability Classification System for Children With Cerebral Palsy) classifica a habilidade manual de crianças com paralisia cerebral (ELIASSON et al, 2006). Estes instrumentos caracterizam-se como escalas ordinais de cinco níveis que retratam, em ordem decrescente, o nível de independência e funcionalidade das crianças.

Em relação ao GMFCS, a classificação é feita de acordo com a idade da criança (PALISANO et al., 1997). No MACS, independente da idade, as crianças são classificadas da seguinte forma: Nível I são capazes de manipular objetos facilmente; nível II são aquelas que manipulam objetos com menor qualidade; nível III são as crianças que manipulam objetos com dificuldade necessitando de ajuda ou adaptação da atividade; nível IV são crianças que executam atividades manuais com êxito limitado, necessitando de supervisão contínua; e nível $\mathrm{V}$ enquadram-se as crianças severamente comprometidas nas habilidades manuais, necessitando de assistência total (ELIASSON et al., 2006).

\subsubsection{Participante A}

Um aluno do gênero masculino, com três anos de idade na época da coleta dos dados, em 2009, com diagnóstico médico de paralisia cerebral. Sobre sua história pregressa, segundo informações obtidas por meio do prontuário sabe-se que ao nascer à criança apresentou anóxia e permaneceu por onze dias no hospital após o parto, a família biológica não apresentava condições de cuidar do filho, pois o pai era alcoólatra e a mãe apresentava doença psiquiátrica, necessitando permanecer internada com frequência. A criança foi encaminhada para um abrigo de menores e adotada com 1 ano e 1 mês, e a família atual sabe pouco sobre sua historia anterior.

O sujeito frequentava atendimento de terapia ocupacional, fisioterapia e fonoaudiologia em um centro especializado de reabilitação de Marília. Também realizava 
acompanhamento médico com neurologista, oftalmologista, ortopedista, otorrinolaringologista e pediatra. Faz uso da medicação Baclofen e Nootron.

No que tange aos aspectos motores, o participante apresentava um tetraparesia espástica, com hipertonia muscular, não sentava sem apoio, não sustentava o tronco, não andava, tinha dificuldades em segurar objetos e manipulá-los. O membro superior da criança permanecia em padrão flexor, com encurtamento da musculatura extensora (dificuldade em estender os braços), apresentava maior facilidade em manusear os objetos com a mão esquerda, nos membros inferiores tinha eversão dos pés (pés voltados para a frente). Com apoio a criança permanecia sentada sobre a região do sacro com aumento da cifose torácica. Apresentava uma limitação da amplitude de movimento, hiperreflexia, encurtamentos musculares e atraso no desenvolvimento neuropsicomotor.

Em relação à classificação funcional, no GMFCS a criança foi classificada em nível $\mathrm{V}$, o que significa que a sua deficiência física restringe o controle voluntário do movimento e a capacidade de manter posturas antigravitacionais de cabeça e tronco. Todas as áreas de função motora estão limitadas, as posturas de sentar e ficar em pé não são completamente compensadas por meio do uso de adaptações e de tecnologia assistiva. A criança não mostra sinais de locomoção independente e é transportada. Os resultados do MACS também apontaram para a classificação a nível V, o que indica que a criança não manipula objetos e tem capacidade severamente limitada para executar as ações simples, necessitando de assistência total.

Quanto aos aspectos oftalmológicos à criança tinha estrabismo e fazia uso de lente de correção visual. Segundo avaliação médica apresentava baixa visão secundária à lesão no sistema nervoso central, não sendo possível avaliar precisamente a sua visão residual. A criança realizava estimulação visual nos atendimentos de terapia ocupacional e suas respostas eram assistemáticas, variando em relação ao tamanho, cores, foco luminoso e distância em que o objeto era apresentado.

A criança não tinha cadeira de rodas adaptada, permanecendo em sua casa em carrinho de bebê convencional. Quando era necessário sair de casa os pais realizavam a sua locomoção no colo.

Nas atividades de vida diária era dependente, necessitava de auxilio total no banho, na higienização bucal, na troca de roupas, na alimentação. Não possuía controle de esfíncter anal e vesical sendo necessário o uso de fralda descartável.

Em relação à comunicação iniciou a fala após intervenção por meio de recursos da comunicação alternativa e no momento da coleta de dados embora tivesse a possibilidade de 
utilizar a fala ela era restrita ao contexto de suas vivências. Observou-se que tinha habilidade de repetição de fala e em algumas situações sem saber o real significado. Quando dominava o conteúdo, elaborava várias frases simples e relatava fatos de sua vivência com auxílio do interlocutor. Não mantinha o vedamento labial e apresentava constante sialorréia.

No que tange aos aspectos cognitivos a criança apresentava boa compreensão, entendia ordens, se mantinha atenta e interessada nas atividades propostas, demonstrava memória auditiva satisfatória.

Em relação ao brincar, apesar de apresentar a intenção de pegar os brinquedos, tinha dificuldade em manuseá-los, impedindo que as brincadeiras ocorressem de forma convencional. Entre as atividades de seu interesse estavam brincadeiras com música e brinquedos sonoros.

Frequentava uma classe especial para alunos com deficiência física de uma escola municipal de Educação Infantil em uma cidade do interior de São Paulo no período da manhã. A sala tinha nove alunos matriculados e estes apresentavam deficiência física com outros comprometimentos associados como a baixa visão e a deficiência intelectual. A sala era ampla, apresentava boa ventilação, suas paredes eram claras e piso emborrachado de cor preta. Em relação à distribuição dos móveis, em uma de suas paredes havia uma lousa e um armário fechado, sendo que as cadeiras adaptadas permaneciam localizadas próximo a lousa, em outra parede se encontravam dois armários abertos onde ficavam alguns brinquedos e materiais para higiene, a sala também contava com uma mesa convencional, baixa com seis cadeiras para crianças. Continha também um tatame no chão localizado próximo a uma barra na parede com altura apropriada para as crianças desta faixa etária. Junto à sala havia um depósito onde eram guardados os equipamentos maiores como cadeiras de rodas, recursos para posicionamento e alguns brinquedos.

A escola tinha disponível materiais pedagógicos adaptados como livros, adaptações para lápis e pincel, suportes de atividades em plano inclinado, painel imantado, letras e brinquedos imantados, entre outros. Possuía equipamentos para atividades de vida diária, cadeiras e mesas adaptadas, cadeira de rodas com possibilidade de ajustes individuais e recursos para posicionamento como cintos, rolos e almofadas. A escola tinha brinquedos de parque adaptados, em relação aos brinquedos da sala eram brinquedos convencionais. Quanto à acessibilidade física a escola oferecia banheiro adaptado e rampas no trajeto até a sala, porém em alguns locais da escola ainda existiam degraus e obstáculos como piso irregular e grama que prejudicavam o acesso. 
$\mathrm{Na}$ área externa, além do parque a escola tinha tanques de areia, uma casa lúdica, sala de vídeo, sala de leitura, a quadra, o refeitório, outras salas de aula do ensino regular e a administração.

\section{Caracterização da Professora do aluno A}

A professora tinha formação em pedagogia, com experiência de 23 anos, cursou habilitação em deficiência física há 17 anos e atua em classe especial para deficientes físicos há 14 anos. Além da classe especial a professora leciona em sala regular da Educação Infantil em período contrario na mesma escola. Durante o período em que estava na classe especial contava com a ajuda de duas auxiliares que se revezavam entre outras atividades da escola.

A professora também conta com o apoio sistemático de profissionais da área da saúde referente à tecnologia na área de comunicação alternativa há 5 anos. Este apoio faz parte de um projeto em Comunicação Alternativa coordenado por uma docente de uma faculdade publica com formação em fonoaudiologia. Quanto ao desenvolvimento desta atividade é realizado um encontro semanal com atuação da coordenadora do projeto e também de três alunas do curso de aprimoramento profissional com formação nas áreas de terapia ocupacional, fisioterapia e fonoaudiologia. As atividades propostas têm como objetivo oferecer o apoio na área de comunicação alternativa e suplementar por meio de recursos e estratégias que venham a favorecer as habilidades comunicativas destas crianças e seu processo de aprendizagem.

\subsubsection{Participante B}

O segundo aluno selecionado para pesquisa era do gênero masculino, tinha 6 anos de idade na época da coleta dos dados, em 2008, com diagnóstico médico de encefalopatia crônica não progressiva. Sobre sua história pregressa, segundo informações obtidas por meio do prontuário não houve intercorrências até o oitavo mês de gravidez, data em que a progenitora entrou em trabalho de parto. Ao nascer a criança apresentou-se cianótica, necessitando permanecer por vinte e quatro dias na incubadora. Por volta de 2 meses necessitou passar por uma neurocirurgia para retirada de um abscesso localizado na região do lobo parietal próximo ao lobo frontal. 
O aluno utilizava serviços de atendimento de terapia ocupacional, fisioterapia e fonoaudiologia em um centro especializado de reabilitação de Marilia. Também era acompanhado por médico neurologista e pediatra. Na época não fazia uso de nenhuma medicação.

Em relação aos aspectos motores, o participante apresentava quadro discinético, com distonia generalizada e atraso no desenvolvimento motor. Apresentava movimentos involuntários e amplos que se acentuavam mediante emoção, mudança de postura ou na realização de movimentos intencionais o que prejudicava a os movimentos voluntários funcionais. Não sentava, não andava, tinha dificuldades em segurar objetos e manipulá-los. O membro superior dominante da criança é o esquerdo, quanto aos membros inferiores à criança gosta de manusear objetos e fazer gestos com os pés.

Referente à sua classificação funcional no GMFCS a criança foi classificada em nível $\mathrm{V}$, o que significa que a dificuldade motora restringe o controle voluntário do movimento e a capacidade de manter posturas antigravitacionais de cabeça e tronco. Todas as áreas de função motora estavam limitadas, as posturas de sentar e ficar em pé não eram completamente compensadas por meio do uso de adaptações e de tecnologia assistiva. A criança não mostrava sinais de locomoção independente e era transportada. Os resultados do MACS indicaram a classificação nível IV, o que indica que a criança é capaz de manipular uma limitada seleção de objetos de fácil manuseio em situações adaptadas, necessita de apoio continuo ou equipamentos adaptados, ainda que para a realização parcial da atividade.

Quanto aos aspectos oftalmológicos a criança foi avaliada não sendo constatado nenhum comprometimento, localizava objetos e pessoas sem dificuldade. Realizou exame audiológico em 2007 e foi verificado que a criança apresentava níveis mínimos de respostas compatíveis com a normalidade.

A criança tinha em sua casa cadeira de rodas e andador, durante o dia preferia ficar no andador, pois ele permitia independência na locomoção, assim utilizava a cadeira apenas em passeios.

Nas atividades de vida diária era dependente, necessitando de auxilio no banho, na higienização bucal, na troca de roupas, na alimentação. Possuía controle de esfíncter anal e vesical.

Em relação à comunicação a criança apresentava discurso inteligível com vocalizações e emissões de algumas palavras. Segundo informações colhidas do setor de fonoaudiologia quando o aluno pronunciava palavras apresentava alterações nas habilidades fonológicas, lexicais e semânticas. O aluno se comunica com o auxilio da comunicação 
alternativa se expressando através de pranchas de comunicação, gestos e olhar. Nos atendimentos fonoaudiológico participava de um programa de comunicação suplementar e alternativa que tinha como objetivo trabalhar o vocabulário, estrutura frasal, consciência fonológica, relação grafema/fonema e maximizar o uso dos recursos de comunicação alternativa. Apresentava dificuldade no vedamento labial, constante sialorréia e engasgo com líquidos.

Nos aspectos cognitivos a criança apresentava compreensão e memória preservadas, entendia ordens, tinha iniciativa em propor atividades e mantinha a atenção por longo período.

Em relação ao brincar apresentava interesse em realizá-las, propunha brincadeiras e seguia regras. Devido ao quadro motor apresentava dificuldades em pegar os objetos e manuseá-los, impedindo que ele tivesse independência durante o brincar. Entre as atividades de seu interesse estavam o computador e jogos.

Frequentava uma sala do Pré III de uma escola municipal de Educação Infantil em uma cidade do interior de São Paulo no período da manhã. A sala tinha vinte e um alunos matriculados sendo que apenas o participante tinha necessidades educacionais especiais. A sala era ampla, apresentava boa ventilação, suas paredes eram claras com o piso frio em tom cinza. Em relação à distribuição dos móveis, em uma de suas paredes havia uma lousa e em seguida a mesa da professora, em uma parede lateral se encontravam dois armários fechados onde ficavam os matérias pedagógicos, as carteiras estavam em frente à lousa, sendo distribuídas em 6 fileiras de 5 carteiras cada, contando com o total de 30 carteiras.

A escola tinha disponível materiais pedagógicos convencionais. Em relação aos recursos para auxilio nas atividades de vida diária tinha um copo adaptado que foi trazido pela mãe do aluno participante do estudo. Quanto aos equipamentos para o posicionamento a escola tinha apenas uma cadeira de rodas que não era adequada ao paciente, sendo que o mesmo trazia o andador de sua casa e permanecia com ele por todo período.

A criança sentava na primeira carteira da sala, ao lado da mesa da professora, segundo informações da professora ele não realizava atividades adaptadas, pois o aluno não queria ser diferente das demais crianças. $\mathrm{O}$ aluno contava com a ajuda colegas da sala durante as atividades escolares.

Em relação à acessibilidade física a escola oferece banheiro adaptado e rampas, porém, nos trajetos internos encontrava muitos obstáculos que prejudicavam o acesso como chão irregular, terra e grama. 
$\mathrm{Na}$ área externa, a escola oferecia o parque (não tinha brinquedos adaptados), tanques de areia, sala de vídeo, sala de leitura, a quadra, campo de futebol, quiosques, o refeitório, outras salas de aula do ensino regular e a administração.

\section{Caracterização da professora do aluno B}

A professora tinha formação em pedagogia e artes, com experiência de 16 anos, não cursou nenhum curso especifico para trabalhar com crianças com necessidades especiais. Segundo relato da professora há 5 anos ela atua com crianças deficientes que são incluídas em sua sala, este ano é a primeira vez que ela recebe crianças com deficiência física pois anteriormente atuou com alunos com deficiência intelectual. Durante suas atividades ocasionalmente recebe ajuda de uma estagiária que atende toda a escola. No período contrario a professora é coordenadora pedagógica da mesma escola.

A escola também conta com o apoio de profissionais da área da saúde referente à tecnologia na área de comunicação alternativa, porém de forma não sistematizada. O apoio também é realizado através do projeto em Comunicação Alternativa coordenado por uma docente de uma faculdade publica com formação em fonoaudiologia que realizava visitas a escola com o objetivo de oferecer orientações referentes à área de comunicação alternativa e suplementar.

\subsection{Local e Período}

As atividades vinculadas à coleta de dados foram realizadas no período de agosto de 2008 a julho de 2009, nas salas de aula dos participantes, ou seja, em escolas de Educação Infantil do município de Marília-SP.

\subsection{Materiais e Equipamentos}

Foram utilizados os seguintes materiais para da coleta de dados: um gravador digital, utilizado para gravar as entrevistas com as professoras; uma filmadora e fitas de vídeo para a 
filmagem; computador para a análise e transcrição das entrevistas e filmagens; caderno universitário, para anotações pertinentes à observação da coleta de dados, materiais pedagógicos e brinquedos.

\subsection{Formas de Registro}

No presente trabalho, para viabilizar os objetivos almejados diante do método qualitativo observacional três formas de registro foram utilizadas: a gravação das entrevistas, a tecnologia de vídeo ou filmagem da observação e o registro contínuo das observações, considerados mais adequados para viabilizar a observação dos fatos com precisão, segundo a literatura especializada (FAGUNDES 1985; MAYKUT; MOREHOUSE, 1994; SCHRAIBER, 1995; ROJAS, 1999; PINHEIRO; KAKEHASHI; KREPPNER, 2005; MAUAD, 2004; SCAPPATICCI; IACOPONI; BLAY, 2004).

\subsubsection{Gravação}

A literatura discutiu que as pesquisas qualitativas com uso do roteiro de entrevista como instrumento da coleta de dados devem ser gravadas para ampliar o poder de registro e captação de elementos de comunicação importantes, pausas de reflexão, dúvidas ou entonação da voz, aprimorando a compreensão da narrativa (SCHRAIBER, 1995).

Segundo Rojas (1999), o gravador preserva o conteúdo original e aumenta a confiabilidade dos dados coletados, além de permitir maior atenção ao entrevistado, registrar as falas, silêncios, vacilações e mudanças no tom de voz.

Neste estudo foi utilizada a gravação das entrevistas semi estruturadas por meio do gravador digital. Em relação ao ambiente foi feito um teste com o gravador por meio de uma gravação anterior para garantir que o local fosse livre de ruídos que pudessem interferir na gravação. 


\subsubsection{Filmagem}

Com a evolução tecnológica, surgiram novos instrumentos que permitiram uma melhora nos procedimentos da pesquisa, como no caso a coleta de dados por meio da videogravação. A filmagem passou a captar sons e imagens que podem favorecer a fidedignidade da coleta dos dados observados (PINHEIRO; KAKEHASHI; ANGELO, 2005).

Através da filmagem o pesquisador pode reproduzir a fluência do processo pesquisado, ver aspectos do que foi ensinado e apreendido, observar pontos que podem não ser percebidos. O vídeo proporciona a transformação das qualidades, das características e particularidades do objeto observado. A imagem oferece à prática de observação e descrição, um novo olhar (MAUAD, 2004).

Kreppner (2001), indicou que a filmagem possibilitaria a observação repetida do fenômeno, serviria de instrumento de consenso intra e interobservadores e, também, permitiria a reconstrução ativa do material gravado, ou seja, tal tecnologia viabilizaria a replicação metodológica, bem como a focalização, em diferentes nuances, do fato observado, favorecendo, a criação de novas categorias de análise diante do fato observado.

Dentro desta perspectiva a filmagem torna-se um instrumento capaz de captar o objeto de estudo, pois restringe questões da seletividade do pesquisador e configura a reprodutividade e estabilidade do estudo (SCAPPATICCI; IACOPONI; BLAY, 2004).

A filmagem também contribui de maneira enriquecedora em estudos avaliativos, principalmente, na área da Educação, pois através dele é possível registrar não apenas as manifestações livres, verbais e/ou gestuais, como também as relações sociais dos autores envolvidos no processo (MAYKUT; MOREHOUSE, 1994).

Para a filmagem das atividades vinculadas ao estudo foi utilizado uma filmadora. A gravação em vídeo foi realizada de forma contínua, evitando-se cortes, para se obter uma sequência de todo o processo de trabalho. A filmadora foi posicionada ao lado do sujeito ou em sua frente, dependendo da atividade e local em que foi realizada a coleta (na apresentação dos resultados será descrito a posição da filmadora para cada atividade). Durante as filmagens, a pesquisadora posicionou-se do lado do aluno, junto com a professora, observando tanto as ações do aluno quanto do professor. 


\subsubsection{Diário de Campo para Registro}

Para complementar os dados obtidos através das filmagens foi utilizado um diário de campo para registro continuo do pesquisador.

Segundo Fagundes (1985), a técnica de registro cursivo contínuo consistiria no registro detalhado, em tempo ininterrupto, da ocorrência dos fatos ocorridos e observados na situação de coleta de dados, de acordo com a sequência temporal destes de forma que os eventos observados pudessem ser visualizados como de fato ocorreram.

\subsection{Organização dos procedimentos metodológicos de pesquisa}

Com a preocupação em sistematizar uma sequência de procedimentos para definir a atividade de confeccionar recursos de tecnologia assistiva para alunos com paralisia cerebral na escola, esta pesquisa foi norteada pela proposta de Manzini e Santos (2002).

Como já descrito anteriormente Manzini e Santos (2002), alertaram a importância das tarefas estabelecidas no fluxograma de orientação para auxilio no processo de aprendizagem do aluno com deficiência:

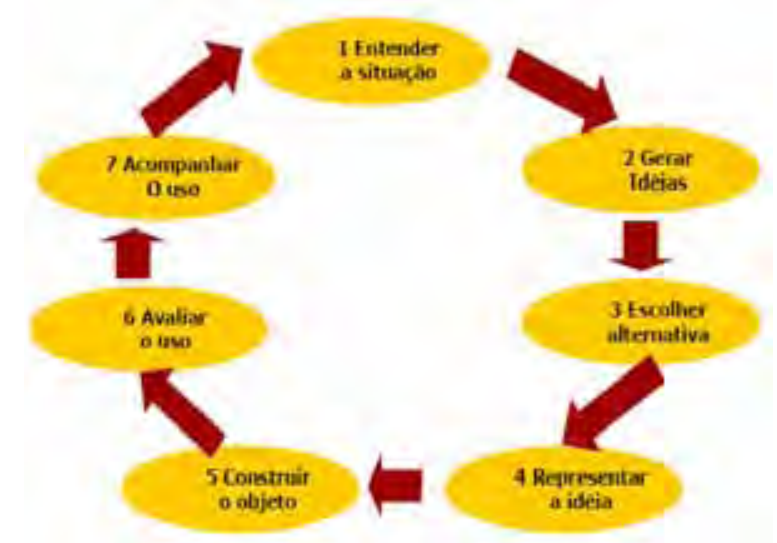

Figura 2- Fluxograma para desenvolvimento de tecnologia assistiva na escola (MANZINI; SANTOS; 2002)

Para a presente pesquisa embora o fluxograma tenha sido contemplado na integra, nesta pesquisa serão apresentados a sequência de tarefas do fluxograma de 1 a 5 , frente ao objetivo proposto para esta pesquisa. 
Conforme a definição de atividade já descrita anteriormente, "atividade é um conjunto de tarefas", ficou estabelecido que a atividade de confeccionar recurso deve envolver as seguintes tarefas do fluxograma: entender a situação; gerar idéias; escolher as alternativas; representar a idéia e por fim construir o objeto que é o recurso definido nesta pesquisa. Cabe retomar ainda, que cada tarefa pode envolver procedimentos com estratégias especificas. O esquema a seguir ilustra a organização da sequência estabelecida para esta pesquisa:

\section{ATIVIDADE}

Confeccionar recurso de Tecnologia Assitiva

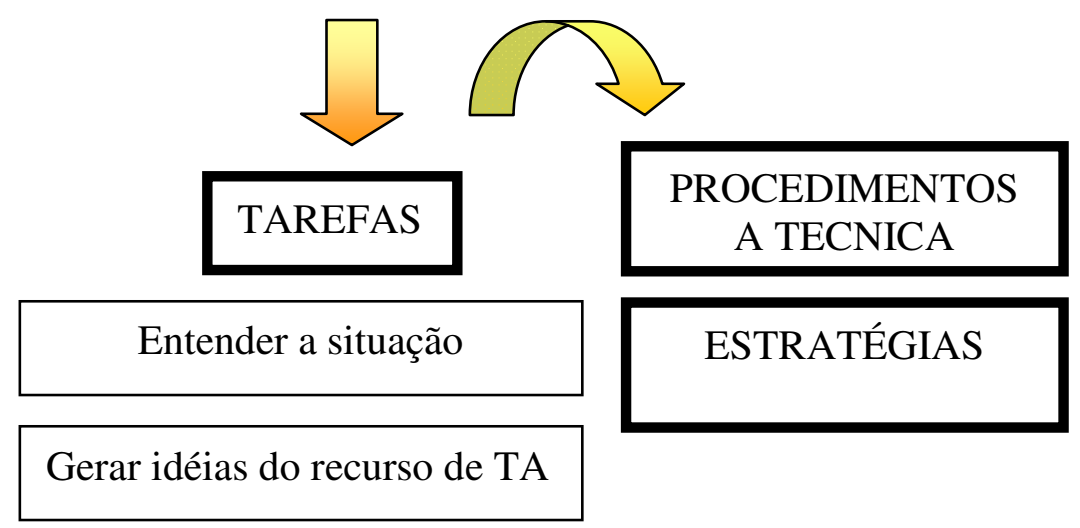

Escolher as alternativas

Representar a idéia

Confeccionar o recurso

Figura 3 - Esquema da atividade, tarefas e procedimentos de pesquisa.

A partir desta organização no Quadro 1 serão descritas as Tarefas da atividade alvo estabelecida nesta pesquisa: 


\begin{tabular}{|c|c|c|}
\hline Tarefas & Procedimentos das tarefas & $\begin{array}{c}\text { Instrumentos para a coleta } \\
\text { de dados das tarefas }\end{array}$ \\
\hline $\begin{array}{l}\text { Tarefa } 1 \text { - Entender a } \\
\text { situação }\end{array}$ & $\begin{array}{l}\text { Entrevista com os professores } \\
\text { Registro no Protocolo de identificação da } \\
\text { rotina escolar pelo professor } \\
\text { Observação do aluno }\end{array}$ & $\begin{array}{l}\text { Roteiro de entrevista } \\
\text { Protocolo de Identificação da } \\
\text { rotina escolar } \\
\text { Filmagem } \\
\text { Registro contínuo }\end{array}$ \\
\hline Tarefa 2 - Gerar idéias & $\begin{array}{l}\text { Informações obtidas por meio das } \\
\text { categorias identificadas na tarefa } 1 \\
\text { Perante três elementos estabelecidos para } \\
\text { o contexto escolar: características do } \\
\text { aluno; planejamento do professor e } \\
\text { desempenho esperado da sala }\end{array}$ & Quadro de registro 1 \\
\hline $\begin{array}{l}\text { Tarefa } 3-\text { Escolher } \\
\text { alternativas }\end{array}$ & $\begin{array}{l}\text { Informações obtidas por meio das } \\
\text { categorias estabelecidas na tarefa. } \\
\text { Informações obtidas por meio dos } \\
\text { resultados do quadro de registro da tarefa } \\
2 .\end{array}$ & Quadro de registro 2 \\
\hline $\begin{array}{l}\text { Tarefa } 4 \text { - Representar } \\
\text { idéias }\end{array}$ & $\begin{array}{l}\text { Informações obtidas por meio do quadro } \\
\text { de registro } 2 \text { e idéias descritas por meio } \\
\text { da literatura. }\end{array}$ & $\begin{array}{l}\text { Descrição do Protótipo do } \\
\text { recurso }\end{array}$ \\
\hline $\begin{array}{lr}\text { Prescrever } & \text { e/ou } \\
\text { confeccionar } & \text { o recurso } \\
\text { de TA } & \end{array}$ & $\begin{array}{l}\text { Descrição do protótipo do recurso e } \\
\text { Materiais necessário perante as categorias } \\
\text { estabelecidas na tarefa } 1 .\end{array}$ & Confecção do recurso de TA \\
\hline
\end{tabular}

Quadro 1 - Descrição das tarefas da atividade de confeccionar recurso de TA

A seguir serão descritas as tarefas descritas no quadro com os procedimentos e estratégias utilizadas

$\mathrm{Na}$ tarefa 1 os procedimentos foram direcionados para entender a situação, ou seja, obter informações sobre o aluno com paralisia cerebral e o seu contexto escolar. Nas tarefas 2 , 3, 4 e 5, os procedimentos proporcionaram ao pesquisador elementos para a construção do recurso de tecnologia assistiva. Nestas tarefas os procedimentos direcionaram estratégias com a finalidade de gerar idéias de recursos de tecnologia assistiva, seguida por escolher as alternativas viáveis, representar a idéia e finalmente prescrever e/ou construir o recurso de tecnologia assistiva.

\subsubsection{Tarefa1 - Entender a Situação}

Nesta etapa foi realizada a identificação dos dados referentes às crianças com paralisia cerebral em seu contexto escolar com finalidade entender o aluno e o ambiente. No 
que se refere ao aluno, os autores Manzini e Santos (2002), salientaram a necessidade de identificar as características físicas, psicomotoras, de comunicação e também os seus interesses. Quanto ao ambiente é necessário observar a dinâmica do estudante no ambiente escolar e reconhecer o contexto social. Estes dados nortearam o pesquisador para a segunda etapa da pesquisa: a construção do recurso. Por meio das informações do aluno e do ambiente seria possível estabelecer critérios para elaborar recursos com perspectivas funcionais.

\subsubsection{Procedimentos e Instrumentos para coleta de dados}

A etapa da coleta de dados contou com três procedimentos sucessivos tendo instrumentos específicos em cada uma delas. O Quadro 2 descreve os procedimentos dessa etapa bem como os instrumentos utilizados.

\begin{tabular}{|l|l|}
\hline \multicolumn{1}{|c|}{ Procedimentos para coleta de dados } & \multicolumn{1}{c|}{ Instrumento de coleta de dados } \\
\hline Entrevistas com os professores & Roteiro de entrevista semi estruturado \\
\hline $\begin{array}{l}\text { Preenchimento pelo professor do Protocolo } \\
\text { de identificação da rotina escolar }\end{array}$ & Protocolo de Identificação da Rotina Escolar \\
\hline Observação dos participantes em sala de aula & $\begin{array}{l}\text { Filmagens } \\
\text { Registro contínuo em diário de campo }\end{array}$ \\
\hline
\end{tabular}

Quadro 2 - Procedimentos e Instrumentos para coleta de dados da Tarefa 1

Os procedimentos e estratégias pertencentes à coleta de dados desta etapa da pesquisa foram realizados da seguinte forma:

\subsection{Entrevistas com professores}

A entrevista tem sido um dos recursos mais utilizados em pesquisas na Educação Especial, sendo possivelmente o mais adequado para obter certos tipos de informações, tais como as que dizem respeito a concepções que se tem sobre determinado objeto (DIAS; OMOTE, 1995; MANZINI, 2003, OMOTE, 2003). 
A entrevista é um método que oferece eficácia para obter dados relevantes e significativos, bem como a possibilidade de submeter os dados a mensuração e análise (MANZINI, 2003).

Para a utilização da entrevista é importante o processo de elaboração de um roteiro. Segundo Manzini (2003), a elaboração de um roteiro pode auxiliar o pesquisador na condução da entrevista, garantindo a coleta de todas as informações desejadas.

Ao se elaborar um roteiro de entrevista devem ser tomados alguns cuidados metodológicos, desde o planejamento da coleta de informações até as variáveis que podem afetar os dados e a futura análise. É necessário verificar se a linguagem esta adequada; se as perguntas realizadas pelo pesquisador são compreendidas; a necessidade de modificações ou ampliações do número de questões ou da sequência estabelecida; e se as perguntas permitirão identificar dados adequados para a análise do objeto de estudo (MANZINI, 2003).

Para esta pesquisa foi utilizado como instrumento de coleta de dados um roteiro de entrevista semi estruturado para as professoras, com o objetivo de se obter informações referentes à criança durante as atividades em sala de aula. Para elaboração do roteiro de entrevista foram utilizados referenciais teóricos sobre o desenvolvimento infantil e a Educação Infantil e também o critérios para elaboração de roteiro de entrevista discutidos por Manzini (2003).

Inicialmente o roteiro de entrevista era composto pelo preâmbulo, local onde são registradas as orientações e os objetivos da entrevista; 27 questões divididas nos temas de rotina escolar e atividades lúdicas, dados para caracterização do professor e do aluno. Com o intuito de garantir a viabilidade do roteiro, o mesmo foi encaminhado para apreciação de dois juízes com experiência na área de Educação Especial.

Após sugestões indicadas pelos juízes quanto ao conteúdo e a forma das perguntas o roteiro foi modificado para a segunda versão (APENDICE C).

A coleta de dados foi realizada através de encontros únicos e individuais com as professoras, com duração aproximada de uma hora, nas escolas das crianças selecionadas.

Com a autorização dos professores, a entrevista foi gravada por meio de um gravador digital. Também foram realizadas anotações de ocorrências físicas e sociais que poderiam prejudicar a entrevista em um diário de campo. 


\subsection{Protocolo de identificação da rotina escolar}

Foi elaborado um protocolo para registrar e identificar a rotina escolar do aluno na Educação Infantil (APENDICE D). Este protocolo foi utilizado como instrumento de coleta de dados e para sua elaboração foi utilizado como referência o semanário, documento no qual o professor organiza sua proposta de trabalho durante a semana.

Nesta pesquisa este protocolo teve como função registrar as diversas atividades que o aluno participava durante a semana, a fim de identificar as demandas dentro do contexto escolar. O registro no protocolo foi feito pelo professor no decorrer da semana.

Este protocolo foi organizado em formato de tabelas, sendo necessárias cinco tabelas, cada uma referente a um dia da semana (de segunda à sexta-feira). Cada tabela continha 5 colunas e 10 linhas, sendo que na primeira coluna estavam estabelecidos os horários de atividades na escola (distribuídos a cada meia hora), e na primeira linha as informações que se pretendia obter referente a cada horário: (1) Local: indica qual o espaço físico que o aluno realizava a atividade; (2) Responsável: este item refere às pessoas que acompanhavam o aluno naquela atividade, ou seja, a professora, a auxiliar, estagiários, se existia mais de uma pessoa responsável pela criança naquele momento; (3) Atividade: corresponde as atividades realizadas na escola, entre elas as atividades em sala de aula, brincadeiras, jogos, refeições, atividades para higienização, atividades em sala de vídeo ou computador; (4) Material: refere-se ao recursos, os objetos utilizado para realizar as atividades, entre eles materiais escolares, brinquedos, jogos, computador, DVD, CD.

O Protocolo da rotina da sala de aula foi entregue à professora no final da entrevista, nesse momento a professora recebeu as explicações sobre o seu conteúdo e a forma de preenchê-lo; em seguida a pesquisadora perguntou se a mesma tinha alguma dúvida e enfatizou a necessidade de sua entrega na próxima semana, ou seja, no primeiro dia de observação do aluno selecionado.

\subsection{Observação dos participantes em sala de aula}

Foram realizados quatro encontros ao longo de um mês para observação do aluno em sala de aula, os encontros ocorreram uma vez por semana durante o período escolar. As 
observações tiveram como objetivo conhecer a realidade vivenciada pelo participante do estudo no contexto escolar. A pesquisadora pode verificar as dificuldades e habilidades dos participantes, sendo que esse processo facilitou a identificação das necessidades dos recursos e serviços da tecnologia assistiva.

Segundo Danna e Matos (2006), durante a observação são registrados dados visíveis e de interesse da pesquisa. Como instrumentos de coleta de dados foram utilizados a filmagem e o registro contínuo em diário de campo, desta forma as observações eram filmadas e também retratadas pela pesquisadora por meio de anotações em um caderno universitário, no qual realizava o registro continuo dos fatos observados no ambiente escolar.

\subsubsection{Organização dos procedimentos de coleta de dados}

Com a finalidade de descrever os procedimentos realizados com os dois participantes na Tarefa 1, o Quadro 3 (participante A) e o Quadro 4 (participante B), permitem visualizar a sequência estabelecida:

\begin{tabular}{|c|c|c|}
\hline Data & Procedimentos de coleta de dados & $\begin{array}{l}\text { Instrumentos de pesquisa } \mathrm{e} \\
\text { formas de registro }\end{array}$ \\
\hline $\begin{array}{c}18 / 03 / 09 \\
\text { Tarefa } 1 \\
1^{\circ} \text { encontro }\end{array}$ & $\begin{array}{l}\text { Entrevista com a professora } \\
\text { Entrega do Protocolo de Identificação de Rotina } \\
\text { Escolar para a professora e orientações sobre como } \\
\text { realizar o registro }\end{array}$ & $\begin{array}{l}\text { Roteiro da entrevista } \\
\text { Gravação ( } 47 \text { minutos) } \\
\text { Protocolo de Identificação } \\
\text { da Rotina Escolar }\end{array}$ \\
\hline $\begin{array}{c}25 / 03 / 09 \\
\text { Tarefa } 1 \\
2^{\circ} \text { encontro }\end{array}$ & $\begin{array}{l}\text { Devolução do Protocolo de Identificação da Rotina } \\
\text { Escolar para a pesquisadora } \\
\text { Observação - Atividades com bola e carrinhos e } \\
\text { observação da criança durante a alimentação }\end{array}$ & $\begin{array}{l}\text { Filmagem (28minutos) } \\
\text { Registro contínuo }\end{array}$ \\
\hline $\begin{array}{c}01 / 04 / 09 \\
\text { Tarefa } 1 \\
3^{\circ} \text { encontro }\end{array}$ & $\begin{array}{l}\text { Observação - Atividades na areia e com bola } \\
\text { observação da criança durante a alimentação }\end{array}$ & $\begin{array}{l}\text { Filmagem (54 minutos) } \\
\text { Registro contínuo }\end{array}$ \\
\hline $\begin{array}{c}08 / 04 / 09 \\
\text { Tarefa } 1 \\
4^{\circ} \text { encontro } \\
\end{array}$ & $\begin{array}{l}\text { Observação - Atividade de tinta guache e papel, } \\
\text { atividades na areia e observação da criança durante a } \\
\text { alimentação }\end{array}$ & $\begin{array}{l}\text { Filmagem (47 minutos) } \\
\text { Registro contínuo }\end{array}$ \\
\hline $\begin{array}{c}15 / 04 / 09 \\
\text { Tarefa } 1 \\
5^{\circ} \text { encontro }\end{array}$ & $\begin{array}{l}\text { Observação - Atividades com carrinho e bonecas e } \\
\text { música e observação da durante a alimentação }\end{array}$ & $\begin{array}{l}\text { Filmagem ( } 68 \text { minutos) } \\
\text { Registro contínuo }\end{array}$ \\
\hline
\end{tabular}

Quadro 3 - Cronograma de atividades do Participante A 


\begin{tabular}{|c|c|c|}
\hline Data & Procedimentos de coleta de dados & $\begin{array}{c}\text { Instrumentos de pesquisa e } \\
\text { formas de registro }\end{array}$ \\
\hline $\begin{array}{c}13 / 08 / 08 \\
\text { Tarefa } 1 \\
1^{\circ} \text { encontro }\end{array}$ & $\begin{array}{l}\text { Entrevista com o professor } \\
\text { Entrega do Protocolo de Identificação de Rotina } \\
\text { Escolar para o professor e orientações sobre como } \\
\text { realizar o registro }\end{array}$ & $\begin{array}{l}\text { Roteiro da entrevista } \\
\text { Gravação ( } 28 \text { minutos) } \\
\text { Protocolo de Identificação } \\
\text { da Rotina Escolar }\end{array}$ \\
\hline $\begin{array}{c}20 / 08 / 08 \\
\text { Tarefa } 1 \\
2^{\circ} \text { encontro }\end{array}$ & $\begin{array}{l}\text { Devolução do Protocolo de Identificação da Rotina } \\
\text { Escolar para a pesquisadora } \\
\text { Observação - Atividade de chegada no quiosque, } \\
\text { atividade na sala de Vídeo, refeitório e no tanque } \\
\text { de areia. }\end{array}$ & $\begin{array}{l}\text { Filmagem (42 minutos) } \\
\text { Registro contínuo } \\
\end{array}$ \\
\hline $\begin{array}{c}27 / 08 / 08 \\
\text { Tarefa } 1 \\
3^{\text {o encontro }}\end{array}$ & $\begin{array}{l}\text { Observação - Atividade de chegada no quiosque, } \\
\text { ensaio de data comemorativa, atividade na sala de } \\
\text { vídeo, refeitório e atividade de colagem de letras } \\
\text { para formar nome de animais. }\end{array}$ & $\begin{array}{l}\text { Filmagem (37 minutos) } \\
\text { Registro contínuo }\end{array}$ \\
\hline $\begin{array}{c}03 / 09 / 08 \\
\text { Tarefa } 1 \\
4^{\circ} \text { encontro }\end{array}$ & $\begin{array}{l}\text { Observação - Atividade de chegada no quiosque, } \\
\text { ensaio de datas comemorativas, refeitório e } \\
\text { atividade de leitura na quadra. }\end{array}$ & $\begin{array}{l}\text { Filmagem (23 minutos) } \\
\text { Registro contínuo }\end{array}$ \\
\hline $\begin{array}{c}15 / 04 / 09- \\
\text { Tarefa } 1 \\
5^{\circ} \text { encontro }\end{array}$ & $\begin{array}{l}\text { Observação - Atividade de chegada no quiosque, } \\
\text { atividade com brinquedos diversos no campo, } \\
\text { refeitório e atividade de matemática em sala. }\end{array}$ & $\begin{array}{l}\text { Filmagem ( } 51 \text { minutos) } \\
\text { Registro contínuo }\end{array}$ \\
\hline
\end{tabular}

Quadro 4 - Cronograma de atividades do Participante B

\subsubsection{Procedimento para organização do material para análise}

Para análise das informações obtidas na Etapa 1 deste estudo foram utilizados quatro procedimentos:

a) Transcrição dos dados da entrevista com o professor;

b) Agrupamento do conteúdo obtido através de do Protocolo de Identificação de Rotina Escolar em um quadro de análise;

c) Transcrição dos dados obtidos através filmagem;

d) Organização das informações do diário de campo.

\subsection{Transcrição da Entrevista com o Professor}


A utilização de entrevista semi-estruturada demanda atenção na análise das informações coletadas. Manzini (2003), orientou que a análise deve levar em conta o objetivo da pesquisa, buscando-se a interpretação dos dados, advindos do conteúdo da fala do entrevistado. As informações verbais identificadas deverão ser transformadas em classes ou categorias de análise.

Após a coleta as entrevistas foram transcritas na íntegra, utilizando o computador, logo após a sua efetivação. Em seguida deu-se inicio o processo de análise.

Para a sua transcrição foram aplicadas as normas de Marcuschi (1986), com a finalidade de facilitar a padronização das informações. Foram utilizados os seguintes critérios para transcrição: (1) as pausas pequenas foram indicadas com um sinal + para cada 0,5 segundos, pausas com mais de 1,5 segundos indicou-se o tempo; (2) para subidas na entonação de voz foram utilizadas aspas duplas (“); (3) para sílabas ou palavras pronunciadas com ênfase ou acento mais forte que o habitual foi utilizado letras maiúsculas; (4) quando não se entendeu parte da fala, foi marcado o local com parênteses e utilizado a expressão inaudível; (5) para alongamento da vogal foi utilizado dois pontos ( : ) dependendo da duração os dois pontos foram repetidos; (6) Para ser introduzido comentários do entrevistador foi utilizado (( )); (7) para as repetições foram utilizados a reduplicação da letra ou sílaba; (8) Para sobreposição de vozes, quando dois falantes iniciam ao mesmo tempo um turno, usam-se colchetes [ .

Com o objetivo de garantir a fidedignidade e a ampliação das informações colhidas foi utilizado o procedimento de validação intraobservador. Desta forma, após uma semana, a entrevista foi novamente transcrita pelo pesquisador, sendo realizada uma comparação com a transcrição anterior.

\subsection{Agrupamento do Protocolo de Identificação Rotina Escolar}

Para a análise do protocolo de rotina escolar os dados foram agrupados em categorias que correspondiam às informações solicitadas, ou seja, o local das atividades, os responsáveis pelo aluno, as atividades e o material. Com intuito de facilitar a visualização destas informações os dados obtidos nas cinco tabelas (cada uma referente a um dia de aula da semana), foram agrupados em um único quadro, sendo eliminadas as informações referentes ao dia da semana e horários, utilizados apenas para a orientação do professor no momento da 
coleta dos dados, e também as informações que se repetiam. A seguir segue o modelo do quadro utilizado para o agrupamento dos dados.

\begin{tabular}{|l|l|}
\hline Local das atividades & \\
\hline Responsáveis pelo aluno & \\
\hline Atividades & \\
\hline Materiais & \\
\hline
\end{tabular}

Quadro 5 - Dados referentes ao Protocolo de Identificação da Rotina Escolar

\subsection{Transcrição da Filmagem}

Foi realizada a transcrição na íntegra das filmagens obtidas durante a observação dos alunos, enfatizando os seguintes aspectos: os recursos utilizados durante as atividades escolares, as estratégias utilizadas pela professora, o desempenho do aluno nas atividades, as habilidades e dificuldades do aluno, a descrição do aspecto motor, a interação do aluno com atividade, professora e os demais alunos e os locais das atividades. Para isto a pesquisadora assistia às imagens gravadas em vídeo e transformava o que estava sendo visto em produção escrita.

\subsection{Organização das informações do diário de campo}

As informações obtidas através do registro contínuo das observações foram selecionadas e agrupadas seguindo os seguintes critérios: os recursos utilizados durante as atividades escolares, as estratégias utilizadas pela professora, o desempenho do aluno nas atividades, as habilidades e dificuldades do aluno, a descrição do aspecto motor, a interação do aluno com atividade, professora e os demais alunos, os locais das atividades. 


\subsubsection{Procedimento para elaboração do material para análise}

Para a elaboração do material para a análise das informações coletadas foi utilizada a proposta de Preto (2009). A proposta de análise estabelecida pela autora prevê a triangulação de dados segundo Triviños (1992), ou seja, agrupamento das informações obtidas em um único documento.

O agrupamento do material teve como objetivo abranger a máxima amplitude na descrição, explicação e compreensão do tema em estudo. Para Triviños (1992), a coleta e a análise de dados fazem parte de uma etapa no processo de pesquisa qualitativa, as quais as informações se retroalimentam constantemente, podendo apenas didaticamente falar, em forma separada, deste tríplice enfoque do fenômeno social. Nesse contexto o autor afirmou "que qualquer idéia do sujeito, documento, etc. é imediatamente descrita, explicada e compreendida, à medida que isso seja possível, na perspectiva da triangulação" (TRIVIÑOS, 1992, p. 139).

Seguindo a proposta da análise citada, as informações obtidas na transcrição da entrevista, a organização dos dados do protocolo de rotina escolar, a transcrição dos dados da filmagem e organização das informações do diário de campo, as informações transformaramse em um texto escrito único no qual obedecem à seguinte sequência:

- Entrevistas com as professoras;

- Informações do protocolo de identificação da rotina escolar;

- Transcrição das filmagens;

- As informações do diário de registro.

Para a compilação das informações em um único documento tomou-se o cuidado de distinguir as informações em função da origem de seu registro, pela utilização de quatro estratégias: a) Letra Times New Roman, em modo Normal, para as informações provenientes da entrevista com os professores; b) Letra Times New Roman, em modo Negrito, para as informações provenientes do protocolo de rotina escolar; c) Letra Times New Roman, em modo Itálico, para as informações provenientes da transcrição das filmagens e d) Letra Times New Roman sublinhada para dados do registro contínuo. 
O documento único gerado através de diferentes instrumentos de pesquisa recebe o nome de técnica da triangulação de dados e segundo Triviños (1992), esta técnica preocupa-se com:

1) os processos e produtos centrados no sujeito;

2) os elementos produzidos pelo meio do sujeito e que têm influência no seu desempenho junto à comunidade;

3) os processos e produtos originados da estrutura socioeconômica e cultural do macro-organismo social, no qual está inserido o sujeito.

\section{7.1.5 Análise da Tarefa 1}

Após elaboração do material para análise, foi necessário estabelecer um procedimento para análise deste material para obter informações a respeito do aluno e seu contexto escolar. Assim, para a sua apreciação foi utilizada a análise de conteúdo, procedimento adequado para análise do material obtido neste estudo (ANDRÉ, 1983).

Após estruturações do texto escrito foram estabelecidas categorias de análise. Bardin (2004), definiu categoria como um conjunto, um grupo ou uma divisão que apresenta características semelhantes, mas que se diferenciam pela natureza. Estas categorias devem ser construídas de maneira que um mesmo elemento não pode ser classificado em duas ou mais categorias.

Foram estabelecidas sete categorias de análise. O Quadro 3 seguir, descreve as categorias e subcategorias: 


\begin{tabular}{|c|c|}
\hline Categorias & Subcategorias \\
\hline 1. $\quad$ Recursos & $\begin{array}{ll}1.1 & \text { Recursos da escola } \\
1.2 & \text { Recursos adaptados da escola }\end{array}$ \\
\hline 2. $\quad$ Estratégias & $\begin{array}{l}\text { 2.1 Estratégias da professora } \\
2.2 \text { Estratégias utilizadas pelos demais membros da } \\
\text { escola }\end{array}$ \\
\hline $\begin{array}{llll}\text { 3. } & \text { Participação do aluno nas } \\
& \text { atividades }\end{array}$ & \\
\hline 4. Desempenho do aluno & $\begin{array}{l}\text { 4.1 Desempenho motor } \\
\text { 4.2 Desempenho perceptivo } \\
\text { 4.3 Desempenho comunicativo }\end{array}$ \\
\hline 5. Conduta do aluno & \\
\hline 6. Interlocutores mediadores do aluno & \\
\hline $\begin{array}{lll}\text { 7. } & \text { Ambientes das atividades } \\
& \text { realizadas pelo aluno }\end{array}$ & \\
\hline
\end{tabular}

Quadro 6 - Categorias e Subcategorias de Análise da Tarefa 1

Para contemplar a analise de conteúdo, segue a definição de cada categoria e subcategoria identificada:

\section{Categoria 1: Recursos}

Entende-se como recursos os materiais escolares, materiais pedagógicos, jogos, brinquedos, utensílios utilizados durante as refeições e processos de higiene do aluno, recursos utilizados para posicionamento, e demais materiais e utensílios, além de CD de músicas, livros de histórias e poesias utilizadas pelo aluno no contexto escolar. Esta categoria foi dividida em duas subcategorias:

(a) recursos da escola: São os recursos convencionais oferecidos pela escola e utilizados por todos os alunos, inclusive o aluno participante desta pesquisa.

(b) Recursos adaptados da escola (recursos de tecnologia assistiva): são os recursos modificados adequados para as especificidades do aluno com deficiência a fim de ampliar o seu desempenho motor, perceptivo, comunicativo e pedagógico. 


\section{Categoria 2: Estratégias}

Neste estudo foi definido como estratégia os procedimentos de execução a fim de mediar o uso dos recursos para a realização de uma atividade, ou seja, como o professor e/ou os demais profissionais utilizavam um recurso para conseguir um objetivo estabelecido.

(a) Estratégia da professora: Foram os procedimentos utilizados pela professora para uso dos recursos com o aluno.

(b) Estratégias utilizadas pelos demais membros da escola: foram os procedimentos utilizados pelos professores auxiliares, monitores, estagiários, motoristas, inspetores e alunos para utilizar os recursos.

\section{Categoria 3: Participação do aluno nas atividades}

Nesta pesquisa a participação foi definida como a realização de ações motoras, comunicativas, perceptivas e comportamentais do aluno durante as atividades realizadas no contexto escolar utilizando os recursos convencionais da escola ou recursos adaptados presentes na escola.

\section{Categoria 4: Desempenho do aluno}

Foi definido por desempenho o rendimento e a qualidade da ação do aluno durante a sua participação nas atividades utilizando os recursos convencionais e adaptados existentes na escola, ou seja, os resultados obtidos pelo aluno por meio de sua participação. Através do seu desempenho é possível identificar suas habilidades e dificuldades.

(a) Desempenho motor: descreve o rendimento e a qualidade da ação motora e do posicionamento do aluno durante atividades, ou seja, o resultado das ações motoras de sua participação. Identifica suas habilidades e dificuldades em relação aos aspectos motores para manuseio do recurso;

(b) Desempenho perceptivo: descreve o rendimento e a qualidade dos aspectos auditivos, visuais, táteis do aluno utilizando os recursos convencionais e adaptados, ou seja, os resultados perceptivos de sua participação; 
(c) Desempenho comunicativo: descreve o rendimento e a qualidade das habilidades comunicativas do aluno durante as atividades do contexto escolar e as questões cognitivas vinculadas a linguagem. Desta forma foi considerada a compreensão do aluno nos momentos em que entendia uma instrução feita pela professora e pelo pesquisador nas diferentes modalidades expressivas (oral e não oral); e também suas diferentes modalidades de expressões observadas pelo professor e pesquisador.

\section{Categoria 5: Conduta do aluno}

Essa categoria foi definida como as reações do aluno frente a um estímulo desencadeado pela sua participação nas atividades. Foram consideradas a reações de alegria, tristeza, birra, choro.

\section{Categoria 6: Interlocutores mediadores do aluno}

Nessa categoria foi definido como interlocutor mediador do aluno as pessoas que participaram das diferentes atividades da rotina escolar, ou seja, as pessoas que permanecem na sala de aula e em outros locais da escola, como por exemplo, a professora, auxiliares de sala, merendeira, coordenadora pedagógica entre outras. Também foram considerados interlocutores mediadores o indivíduo que acompanharam os alunos no transporte escolar, como o motorista do veículo escolar, por exemplo.

\section{Categoria 7: Ambientes das atividades realizadas pelo aluno}

Nessa categoria foram estabelecidos os locais onde a criança realizou atividades na escola, como por exemplo, a sala de aula, o refeitório, o banheiro, sala de vídeo, pátio, parque, tanque de areia, entre outros locais.

\subsection{Submissão das categorias de análise a juízes}

Após se estabelecer as categorias e subcategorias de análise, com o intuito de seguir um rigor conceitual e metodológico de pesquisa, foram utilizadas ao estudo as recomendações 
de Carvalho (1996). Este autor afirmou que o material coletado por meio de instrumentos nas pesquisas qualitativas, quanto a sua categorização, deve ser submetido à análise de juízes.

Desta forma o material coletado foi encaminhado para apreciação de juízes com experiência na área de Educação Especial, com o objetivo de verificar se as categorias e subcategorias elaboradas estavam representadas através das informações selecionadas.

O material encaminhado pela pesquisadora aos juízes continha os objetivos da pesquisa; esclarecimentos sobre os procedimentos da coleta de dados: entrevista semi estruturada com os professores, protocolo de identificação da rotina escolar e observação em sala de aula; as definições de cada categoria e subcategoria e o quadro para a apreciação dos juízes contendo trechos do documento para a análise, sua classificação em categorias e subcategorias e o espaço para a avaliação do juiz.

O material foi entregue aos juízes e, após a análise, foram obtidos os seguintes índices de concordância segundo Carvalho (1996):

\begin{tabular}{|c|c||}
\hline \hline RELAÇÃO ENTRE JUÍZES & ÍNDICE DE CONCORDÂNCIA \\
\hline $\mathrm{P}-\mathrm{A}$ & $86,74 \%$ \\
\hline $\mathrm{P}-\mathrm{B}$ & $90,47 \%$ \\
\hline $\mathrm{A}-\mathrm{B}$ & $88,69 \%$ \\
\hline
\end{tabular}

Tabela 1 - Índice de Concordância obtido entre os juízes

Após a realização do índice de concordância, a pesquisadora fez análise do material apreciado pelos juízes, chegando à conclusão de que as categorias e subcategorias, e seus respectivos exemplares de fala, apresentaram o grau de representatividade segundo Carvalho (1996).

\subsubsection{Tarefa 2 - Procedimentos para pensar no recurso}

Para Manzini e Santos (2002), esse momento é descrito como necessário para gerar idéias. Importante ressaltar que as informações obtidas na tarefa 1 foram fundamentais para esse momento, ou seja, as categorias obtidas podem favorecer a idéia do formato do recurso necessário para um aluno com paralisia cerebral. 
Embora a educação infantil também seja um espaço para cuidar da criança é necessário que a escola e o professor estejam atentos ao planejamento das atividades propostas para que as mesmas contemplem os pré-requisitos para a aquisição da leitura e escrita. Leontivev (1991), discutiu a importância do professor utilizar atividades significativas para a etapa de desenvolvimento dos alunos de forma a favorecer a aprendizagem significativa.

Com a preocupação de gerar idéias, ou seja, pensar em recursos que poderiam favorecer a aprendizagem significativa, foram estabelecidos três elementos para serem os norteadores da Tarefa 1. Os elementos estabelecidos foram: características do aluno com deficiência, planejamento do professor e desempenho dos alunos da sala frente ao planejamento do professor.

O Quadro 6 a seguir descreve os elementos identificados de cada categoria estabelecida na tarefa 1 , perante os três elementos estabelecidos para favorecer a tarefa 2 : característica do aluno com deficiência, planejamento do professor e o desempenho esperado para a sala de aula. 


\begin{tabular}{|c|c|c|c|}
\hline $\begin{array}{l}\text { Categorias } \\
\text { Etapa } 1\end{array}$ & $\begin{array}{c}\text { Característica do aluno } \\
\text { com deficiência }\end{array}$ & $\begin{array}{c}\text { Planejamento do } \\
\text { professor }\end{array}$ & Desempenho da sala \\
\hline Recurso & $\begin{array}{l}\text { Atributos do material: } \\
\text { forma, tamanho, cor, } \\
\text { peso, textura, } \\
\text { consistência }\end{array}$ & Objetivos e metas & Faixa etária \\
\hline Estratégias & $\begin{array}{l}\text { Os procedimentos } \\
\text { necessários para utilizar } \\
\text { um recurso na tarefa }\end{array}$ & $\begin{array}{l}\text { Estabelecer } \\
\text { procedimentos para } \\
\text { desenvolver o conteúdo }\end{array}$ & $\begin{array}{lrr}\text { Grupo de } & \text { alunos } \\
\text { realizarem a } & \text { atividade } \\
\text { estabelecida. } & \end{array}$ \\
\hline Participação & $\begin{array}{l}\text { Aspectos motores, } \\
\text { comunicativos, } \\
\text { sensorial/perceptual, } \\
\text { cognitivos } \\
\text { comportamentais }\end{array}$ & $\begin{array}{l}\text { Para o aluno participar o } \\
\text { professor precisa elaborar } \\
\text { a estratégia }\end{array}$ & $\begin{array}{l}\text { Centro de interesse da } \\
\text { sala. }\end{array}$ \\
\hline Desempenho & $\begin{array}{l}\text { Envolvimento do aluno } \\
\text { do ponto de vista motor, } \\
\text { comunicativo, sensorial e } \\
\text { perceptivo, cognitivo e } \\
\text { comportamental }\end{array}$ & $\begin{array}{llr}\text { Utilizar recursos } & \text { e } \\
\text { estratégias para } & \text { atingir } \\
\text { um conteúdo } & \text { do } \\
\text { planejamento. } & \end{array}$ & $\begin{array}{l}\text { Envolvimento do grupo } \\
\text { de alunos com o recurso } \\
\text { na estratégia estabelecida }\end{array}$ \\
\hline $\begin{array}{l}\text { Conduta do } \\
\text { aluno }\end{array}$ & $\begin{array}{l}\text { Como o aluno } \\
\text { comporta frente a } \\
\text { material }\end{array}$ & $\begin{array}{lrr}\text { Tem como } & \text { meta } \\
\text { envolvimento dos } & \text { alunos } \\
\text { nas tarefas } & \text { do } \\
\text { planejamento } & \\
\end{array}$ & $\begin{array}{l}\text { Envolvimento da sala } \\
\text { com os recursos e } \\
\text { estratégias estabelecidas }\end{array}$ \\
\hline $\begin{array}{l}\text { Interlocutores } \\
\text { e mediadores }\end{array}$ & $\begin{array}{llr}\text { Aluno com } & \text { deficiência } \\
\text { estar com } & \text { diferentes } \\
\text { interlocutores nas tarefas } \\
\text { estabelecidas }\end{array}$ & $\begin{array}{lr}\text { Estratégia de } & \text { mediação } \\
\text { do professor é contemplar } \\
\text { a participação dos alunos } \\
\text { com os diferentes } \\
\text { interlocutores }\end{array}$ & $\begin{array}{l}\text { Envolvimento dos alunos } \\
\text { nas tarefas estabelecidas } \\
\text { por meio da mediação do } \\
\text { interlocutor }\end{array}$ \\
\hline Ambiente & $\begin{array}{l}\text { Favorecer a participação } \\
\text { do aluno com deficiência }\end{array}$ & $\begin{array}{l}\text { Adequar o ambiente para } \\
\text { a diversidade de aluno }\end{array}$ & $\begin{array}{l}\text { Adequar a sala de aula } \\
\text { com os pré requisitos } \\
\text { necessários para a leitura } \\
\text { e escrita }\end{array}$ \\
\hline
\end{tabular}

Quadro 7- Elementos necessários para gerar idéias para a elaboração de recursos

\subsubsection{Tarefa 3 - Procedimentos para escolher as alternativas}

Entre os critérios estabelecidos no momento anterior seria possível formar idéias de recursos que poderiam contribuir com a participação e aprendizagem significativa do aluno com paralisia cerebral no contexto escolar perante o planejamento do professor e em relação ao desempenho dos demais alunos da sala. Embora a tarefa 2 contemple as necessidades do aluno com deficiência, planejamento do professor e os demais alunos, Manzini e Santos (2002), consideraram importantes estabelecer as necessidades a serem atendidas, a disponibilidade de recursos materiais e o custo para a confecção dos recursos. 
Desta forma, na tarefa 3 foram estabelecidos três critérios que permitiriam uma escolha viável do recurso. Os três critérios foram designados a partir das informações da tarefa 1 e, também segundo a literatura pertinente a este assunto (JUDGE; LAHM, 1998; LANGONE; MALONE; KINSLEY, 1999; COPLEY; ZIVIANI, 2004; MANZINI, 2005; ARAUJO; MANZINI, 2001; JUDGE; FLOYD; JEFFS , 2008; PELOSI, 2008, 2009; ROCHA; DELIBERATO, 2009a, 2009b).

1. Fácil acesso a materiais para confecção do recurso adaptado: materiais disponíveis na escola e de fácil disponibilidade para o professor;

2. Orçamento do material: seriam selecionados materiais de baixo custo, ou seja, recursos de baixa tecnologia;

3. Tempo de adaptação do recurso: tempo disponível para a confecção do recurso adaptado.

\subsubsection{Tarefa 4 - Procedimentos para representar a ideia}

O uso do recurso de tecnologia assistiva deve facilitar a acessibilidade do aluno no contexto escolar, deste modo antes de confeccioná-lo é importante conhecer as características físicas dos materiais utilizados e também estabelecer critérios para a escolha de seu formato, peso, tamanho e textura, como já descritos nas tarefas 1, 2 e 3. Segundo Manzini e Santos (2002), deve-se definir nessa tarefa os materiais utilizados e as dimensões do objeto como forma, medida, peso, textura, consistência, cor, conteúdo entre outras necessidades.

Neste momento da intervenção a pesquisadora considerou como critério para a confecção dos recursos o desempenho motor, perceptivo e comunicativo do aluno a fim de selecionar materiais que poderiam favorecer a sua funcionalidade. Para esta tarefa foi elaborado um protocolo de caracterização e dimensões do objeto a ser construído frente às características do aluno com deficiência, uma vez que ainda não se tem padronizações dos atributos de recursos para o aluno com paralisia cerebral (APENDICE E). A literatura discutiu a importância da padronização e generalização de medidas para equipamentos e recursos pedagógicos para alunos com paralisia cerebral para possibilitar o manuseio ou ainda facilitar o acesso ao material, como no caso da pesquisa da Oliveira (2007), Audi (2006) e Paiva (2007). 
A seguir estão definidos os itens designados no protocolo utilizado para representar o recurso adaptado a ser confeccionado:

\section{Estrutura física}

1) Tamanho: são as dimensões ou medidas de um objeto. Para objetos de uma dimensão, é o comprimento, largura ou altura; para objetos de duas dimensões, é a superfície; e para objetos de três dimensões, é o volume (SACKHEIM, 1998).

2) Peso: é a qualidade de um corpo pesado (SACKHEIM, 1998).

3) Volume: a quantidade de espaço ocupada por um corpo (SACKHEIM, 1998).

4) Consistência: é o estado de resistência de um corpo, como por exemplo, firmeza, solidez (SACKHEIM, 1998).

5) Textura: é o aspecto de uma superfície, ou seja, a "pele" de uma forma, que permite identificá-la e distingui-la de outras formas. Quando tocamos ou olhamos para um objeto ou superfície sentimos se a sua pele é lisa, rugosa, macia, áspera ou ondulada. A textura é, por isso, uma sensação visual ou táctil (SACKHEIM, 1998).

6) Forma: é a forma é a configuração visível do conteúdo (ARNHEIM, 1997).

\section{Estrutura visual}

1) Percepção da cor: descreve a percepção visual como um processo ativo de procura de informação. A estrutura percebida é analisada, havendo uma síntese dos componentes com auxílio da linguagem (LURIA, 1991). Como exemplos da percepção visual são possíveis citar a percepção de formas; percepção de relações espaciais, como profundidade; percepção de cores; percepção de intensidade luminosa; percepção de movimentos.

2) Contraste: a diferença nas propriedades visuais que faz com que um objeto seja distinguível de outros e do plano de fundo (FROSTIG; MULLER 1986).

3) Coordenação viso-motora: é definida como a capacidade de coordenar a visão com os movimentos do corpo ou de partes do corpo (FROSTIG; MULLER 1986).

4) Relação espacial: é a percepção das relações espaciais, isto é, a capacidade de perceber a posição de dois ou mais objetos em relação aos demais, é o último aspecto da percepção visual (FROSTIG; MULLER, 1986). 
5) Posição espacial: é a capacidade da pessoa de perceber a posição de um objeto em relação a si mesma (FROSTIG; MULLER, 1986).

6) Figura fundo: é a capacidade para observar um aspecto do campo visual em relação ao resto do próprio campo (FROSTIG; MULLER, 1986).

7) Constância perceptual: é a determinante do modo de perceber as coisas, para que possa registrar internamente as impressões que delas se tem e reconhecê-las ou identificá-las depois. Envolve a habilidade que um indivíduo tem para perceber que um objeto possui propriedades inalteradas, tais como forma, posição e tamanho, a despeito da mudança de sua imagem na retina (LEFÈVRE, 1995; FROSTIG; MULLER,1986).

8) Memória visual: é a habilidade de lembrar daquilo que não está mais à vista (FROSTIG; MULLER, 1986).

\section{Estrutura auditiva}

1) Presença de som (detecção do som): é a habilidade auditiva em que a criança deve perceber a presença e ausência do som (NORTHERN; DOWNS, 1989).

2) Reconhecimento do som: é a habilidade de identificar o som e a fonte sonora com capacidade de classificar ou nomear o que ouviu (NORTHERN; DOWNS, 1989).

3) Compreensão do som: é o ato de estabelecer relações entre o estímulo sonoro produzido, outros eventos do ambiente e o próprio comportamento. Essas relações têm as propriedades de reflexividade, simetria e transitividade (NORTHERN; DOWNS, 1989).

4) Tipos de som (sensação do som): é o recebimento do estímulo sonoro via audição, sendo a partir desta que se percebe se um som é alto ou baixo, grosso ou fino, forte ou fraco, longo ou curto (intensidade, frequência, duração) (NORTHERN; DOWNS, 1989).

5) Atenção ao som: é a capacidade de selecionar estímulos, isto é, focar-se em um determinado estímulo sonoro em meio a outros sons competitivos auditivos e visuais, sendo imprescindível para a seleção de determinados estímulos em detrimento de outros (NORTHERN; DOWNS, 1989). 
6) Discriminação do som: é o ato de diferenciar dois ou mais estímulos sonoros; capacidade para determinar se dois estímulos são iguais ou diferentes (NORTHERN; DOWNS, 1989).

7) Figura fundo auditiva: identificar mensagem primária na presença de sons competitivos (NORTHERN; DOWNS, 1989).

8) Memória auditiva: é o processo que permite armazenar, arquivar informações acústicas para poder recuperá-las depois (NORTHERN; DOWNS, 1989).

\section{Estrutura de comunicação}

\section{1) Compreensão}

1.1) comandos simples: entendimento da criança frente a ordens simples do interlocutor.

1.2) comandos complexos: entendimento da criança frente a ordens complexas do interlocutor, ou seja, quando o interlocutor faz uso de comandos com mais de duas frases.

\section{2) Expressão}

2.1) Vocabulário: palavras, gestos, expressões faciais, sinais, figuras utilizadas pela criança que designam um determinado significado ou sentido.

2.2) Extensão de enunciados: número de elementos utilizados para expressão uma intenção, ideia, sentimento.

\section{4,7.5 Tarefa 5 - Procedimentos para confecção do recurso de tecnologia assistiva}

Nesse momento foram prescritos os recursos de tecnologia assistiva perante os resultados das tarefas $1,2,3$ e 4 . Com os resultados da tarefa 4 , a pesquisadora confeccionou o recurso propriamente dito para ser avaliado e acompanhado durante as atividades escolares. Convém ressaltar que nesta pesquisa serão apresentados os resultados das tarefas 1 a 5 . 


\section{RESULTADOS E DISCUSSÃO}

Os resultados e discussões dos dois alunos participantes e seus professores serão apresentados seguindo os mesmos critérios de organização dos procedimentos realizados nas tarefas para facilitar a identificação da importância do vínculo entre os resultados de uma tarefa com a seguinte, conforme as orientações de Manzini e Santos (2002).

\subsection{Resultados e discussão da Tarefa 1: Entender a situação}

Conforme já foi definido anteriormente serão utilizadas as seguintes padronizações para a apresentação dos resultados obtidos durante os procedimentos realizados na tarefa 1: Letra Times New Roman, em modo normal, para as informações provenientes da entrevista com os professores; Letra Times New Roman, em modo negrito, para as informações provenientes do Protocolo de Identificação da Rotina Escolar; Letra Times New Roman em modo itálico, para as informações provenientes das filmagens da observação; e Letra Times New Roman normal sublinhada, para as informações provenientes do registro contínuo.

A partir dos procedimentos da Tarefa 1 foi possível estabelecer argumentos que permitiram ao pesquisador entender a situação. Conforme apresentado anteriormente a análise dos dados propiciou a construção de categorias, a saber: ambiente das atividades, interlocutor e mediador do aluno, os recursos, as estratégia, a participação do aluno nas atividades, o desempenho do aluno, e a conduta do aluno. Desta forma os resultados e discussões deste estudo serão apresentados seguindo as categorias determinadas.

\subsubsection{Ambiente das atividades}

Pesquisadores da área de tecnologia assistiva discutiram a necessidade de inserir instrumentos e recursos para alunos com deficiência nos diferentes ambientes da escola para que assim os mesmos pudessem favorecer a participação dos alunos com deficiência, no caso, alunos com paralisia cerebral nas atividades desenvolvidas nos diferentes espaços da escola 
(SORO-CAMATS, 2003; BASIL, 2003; MANZINI, 2005; ROCHA; DELIBERATO, 2009a, 2009b; CORREIA, 2010; SILVA, 2010). Autores da educação infantil também alertaram para a necessidade do envolvimento das diferentes crianças nos espaços da escola que propiciem a participarem nas vivências e experiências com diferentes interlocutores e materiais disponíveis (FARIA, 2000; MELLO, 2004, 2007; LEONTIEV, 1991).

Segundo a proposta do Referencial Curricular Nacional para a Educação Infantil o espaço na escola de educação infantil deve propiciar condições para que as crianças possam usufruí-lo em benefício do seu desenvolvimento e aprendizagem. É importante considerar que a aprendizagem transcende o espaço da sala de aula, toma conta da área externa e de outros espaços da escola e fora dela. As atividades devem ser propostas considerando as diferentes necessidades de cada faixa etária (BRASIL, 2001).

Ainda de acordo com a proposta do Referencial Curricular Nacional para a Educação Infantil (2001), as atividades nas áreas externas são importantes para criar espaços lúdicos que sejam alternativos e permitam que as crianças corram, balancem, subam, desçam e explorem ambientes diferenciados.

A fim de enfatizar a importância dos diferentes locais da escola de Educação Infantil, o MEC publicou no ano de 2006 os Parâmetros Básicos de Infra-estrutura para Instituições de Educação Infantil. Este documento preconiza a construção coletiva das políticas públicas para a educação, sendo elaborado em parceria com educadores, arquitetos e engenheiros envolvidos em planejar, refletir, construir ou reformar os espaços destinados à educação das crianças de 0 a 5 anos (BRASIL, 2006c).

Acredita-se que ambientes variados podem favorecer diferentes tipos de interações, porém é importante ressaltar que o professor tem papel fundamental como organizador dos espaços onde ocorre o processo educacional. A escola deve proporcionar aos seus alunos e professores um ambiente agradável e acessível para que as diferentes atividades propostas no planejamento sejam feitas com interesse e participação de todos os alunos. A participação do aluno com paralisia cerebral na tarefa de uma atividade pode demandar de uma estrutura de organização física e pedagógica, como estabelecido por meio de documentos oficiais do Ministério da Educação (BRASIL, 2006c).

No que se refere à estrutura física, o aluno com paralisia cerebral pode necessitar de adequações no piso da sala, barra paralela, posicionamento da lousa, luminosidade apropriada entre outras necessidades. Quanto à organização do planejamento do professor há necessidade da sala ter materiais disponíveis para o aluno com paralisia cerebral participar da tarefa proposta e prevista. 
A sala de aula do participante A oferecia condições de adequações físicas e de materiais para facilitar aos alunos acesso a tarefa proposta independente da sua habilidade ou necessidade. Como já descrito anteriormente a sala do participante A tinha as adequações necessárias por se tratar de uma classe especializada para alunos com deficiência neuromotora, como pode ser observado pelo exemplo a seguir:

\section{Participante A}

A sala de aula era ampla, com boa iluminação e piso emborrachado. Em seu ambiente estavam as cadeiras adaptadas, tatame, barra paralela e acessórios como a calça da vovó, almofadas e rolos.

Por meio do exemplo acima é possível perceber que a sala de aula do aluno A tem instrumentos que podem favorecer a adequação postural não só do participante deste estudo, mas para os demais alunos com deficiência. Braccialli et al. (2008); Braccialli (2009) e Oliveira (2007) discutiram em suas pesquisas há necessidade de adequações de mobiliários no contexto escolar, principalmente na sala de aula, para inserir o aluno com paralisia cerebral na rotina de atividades.

A sala de aula do participante B não dispunha de adequações físicas e de materiais para favorecer ao aluno com paralisia cerebral envolvimento nas diferentes tarefas, como pode ser visualizado por meio do exemplo a seguir:

\section{Participante B}

(...) as carteiras ficavam próximas uma da outra, o que dificultava a locomoção do participante B na sala de aula. O chão é de piso frio e claro, a sala é bem iluminada. Em relação a lousa, foi possível perceber que é elevada não favorecendo o campo visual do participante B.

Embora os documentos oficiais designem as escolas à necessidade de adaptações e adequações para os diferentes alunos com deficiência para garantir acesso às questões pedagógicas, ainda os recursos, estratégias e serviços da área de tecnologia assistiva estão centrados nas classes especiais, salas multifuncionais, salas de recursos e, ainda nas instituições especializadas. O ambiente inclusivo é discutido pela literatura como essencial para a criança com deficiência compartilhar experiências e adquirir conhecimento, mas para que este ambiente inclusivo proporcione aprendizagem significativa, deve ser adequada à diversidade de alunos (SORO-CAMATS, 2003; BASIL, 2003; PELOSI, 2006, 2009; VON TEZTCNHER et al. 2005; VON TEZTCNHER, 2006, 2009). 
Durante a coleta de dados foi possível observar que os participantes A e B frequentavam diferentes espaços da escola. Nas entrevistas feitas com os professores foi possível identificar os seguintes locais:

\section{Participante A}

( ...) também vai ao parque...; ... ele gosta muito da sala de vídeo ++ e tem também o gramado e a sala ++ a are:ia ++ e mais isso.

Participante B

(...)+ as vezes no quiosque também a gente tem o caramachão circulo + a gente tem vários lugares né (...) o parque (...)

Estes dados também foram complementados pelos professores ao responder o Protocolo de Identificação da Rotina Escolar. A seguir estão exemplificados os espaços descritos pelos professores dos alunos participantes:

\section{Participante A}

Sala de aula, sala de vídeo, gramado, pátio, quadra, tanque de areia e parque.

Participante B

PB: Quiosque, tanque de areia, refeitório, sala de aula, sala de TV e leitura, barracão, parque, campo e quadra.

As informações obtidas por meio do registro do Protocolo de Identificação da Rotina Escolar também reforçaram a preocupação dos professores em realizar tarefas de uma atividade com seus alunos em espaços diferentes da sala de aula. O registro das tarefas no protocolo evidenciou a importância do professor planejar e organizar suas ações com seus alunos. Deliberato (2005, 2009) e Sameshima e Deliberato (2009a), discutiram a necessidade do professor realizar seu planejamento e estabelecer suas metas na rotina escolar para que os recursos e estratégias de tecnologias assistivas possam ter maior eficácia para os alunos com deficiência nos diferentes ambientes.

A importância dos alunos da educação infantil participarem de atividades em diferentes ambientes também está sendo recomendada por documentos nacionais, como nos parâmetros e diretrizes para educação infantil e no documento de atendimento especializado. (BRASIL, 1998; BRASIL, 2007). 
Tais documentos reforçaram a necessidade de uso de recursos, estratégias e serviços de tecnologia assistiva nos diferentes ambientes da escola, não sendo restritos às salas de aula, mas devem se estender a todos os ambientes da escola, propiciando o acesso e a participação efetiva de todos os alunos durante todo o tempo (BRASIL, 2007).

Von Tetzchner (2006), discutiu que os diferentes ambientes da escola podem servir como suporte para o desenvolvimento infantil, principalmente para o aluno com deficiência. O mesmo autor também alertou para a necessidade dos diferentes ambientes da escola contribuírem no uso de recursos de tecnologia assistiva, como no caso dos sistemas de comunicação alternativa.

Este fato pode ser observado tanto na escola do participante A quanto do participante B. O exemplo a seguir ilustra a atividade realizada no pátio da escola do aluno A envolvendo não só os alunos da classe especial, mas também, os demais alunos da escola. Este momento era chamado de hora social:

\section{Participante A}

(...) acontece a hora social, onde todas as crianças da escola participam de atividade no pátio da escola (...)

A hora social acima exemplificada ocorre todos os dias e faz parte do planejamento do professor. Nesta atividade as crianças participam com diferentes interlocutores mediadores por meio da seleção de temas significativos para as crianças da educação infantil. Nesta atividade, o aluno A e as demais crianças de sua sala desenvolvem tarefas, como por exemplo, cantar, contar histórias, poesias por meio de recursos e estratégias de comunicação alternativa. Os instrumentos da tecnologia assistiva utilizados nesta situação podem favorecer a ampliação da participação dos alunos com deficiência, como no caso do aluno A, mas também viabiliza a oportunidade das demais crianças e interlocutores mediadores vivenciarem o uso dos recursos da tecnologia no contexto funcional para atender as diversidades dos alunos (VON TEZTCHNER et al., 2005; VON TEZTCHENER, 2006; LIGHT, 2003; DELIBERATO, 2007).

A hora social na escola do Participante B ocorre de forma sistemática, mas por meio de estratégia diferente em relação à escola do participante $\mathrm{A}$, como pode ser observado a seguir: 
No inicio da manha as crianças se dirigiam ao quiosque onde foi cantado a música de chegada (Bom dia Amiguinho como vai) (...)

(...) ainda no quiosque após finalizar a música a professora iniciou uma oração (...)

O exemplo acima ilustra a sequência das duas tarefas da atividade da hora social realizada entre os alunos da sala no quiosque. $\mathrm{O}$ encontro entre todas as salas e alunos da escola ocorre somente no último dia letivo da semana, para cantar o hino nacional. Nestas tarefas o participante B está envolvido com diferentes interlocutores mediadores, mas não com a presença de recursos que favoreçam sua participação. A literatura discutiu a necessidade de pesquisas para identificar se o ambiente segregado oferece maiores oportunidades para o aluno com deficiência em função da disponibilidade de recursos de tecnologias. Os mesmos autores também alertaram que ambientes segregados podem ser facilitadores nos recursos, mas não é suficiente para oferecer suporte de interlocutores competentes para propiciar a generalização da aprendizagem significativa para os demais ambientes (FARIA, 2000; MELLO, 2004; VON TEZTCNHER, 2006).

Outros espaços designados pelos professores foram tanque de areia, gramado, quadra, refeitório, campo, sala de vídeo, como pode ser observado a seguir:

Participante A

(...) eles foram no tanque de areia na primeira parte da manhã...(tanque de areia)

(...) as crianças foram levadas até o tanque de areia... (tanque de areia)

Após trocar todas as crianças, por volta das 10:15 elas foram levadas ao gramado para uma sombra embaixo de uma arvore, onde foi colocado um edredom, almofadas, e as crianças ficaram deitadas e sentadas. (gramado)

Participante B

(...) em seguida a criança foi ate o tanque de areia, permanecendo apoiado na estagiaria que acompanhava... (tanque de areia)

(...) após a escovação de dentes a criança se dirigiu a quadra (...) ele foi até a quadra da escola para junto com as outras salas da escola ensaiar uma música para a inauguração da quadra esportiva. (quadra)

(...) P2 estava posicionado no andador próximo a professora que lia o livro em pé de frente para a arquibancada da quadra onde estavam as outras crianças...(quadra) 
(...) durante a atividade no campo apresentou dificuldade em locomover o andador no gramado...(gramado)

Na sala de vídeo o Participante B se deslocava para frente através do andador ....(sala de vídeo)

Por meio dos exemplos acima é possível observar que os participantes estão envolvidos em tarefas diferenciadas em espaços distintos da escola. Esse fato facilita o contato com os diferentes interlocutores, mesmo que sejam alunos da sala especial. Embora a professora do participante A tenha estabelecido no seu planejamento a participação de seus alunos nos diferentes ambientes da escola, o momento do lanche de sua sala não é compartilhado com as demais crianças da escola, como pode ser observado nos exemplos a seguir:

\section{Participante A}

Ao finalizar a atividade no gramado, professora começou a levar as crianças a sala de aula para o lanche (...)

Foi observado que as crianças da sala de aula do participante A não realizam suas refeições no refeitório da escola, a alimentação é trazida pela servente ou pela professora auxiliar e oferecida ao aluno na própria sala de aula.

Após as refeições uma das auxiliares de sala conduz a criança até um banheiro adaptado ao lado da sala de aula para realizar a higienização das mãos, dentes e troca de fraldas.

As observações realizadas durante a rotina da sala de aula do participante A pode constatar que a situação do lanche oferecida tem como objetivo o cuidar da criança, não proporcionando experiências diferenciadas com outros alunos durante a situação do refeitório, como foi observado com o participante B:

\section{Participante B}

Após a atividade na sala de vídeo as crianças foram levadas ao refeitório.

As 9:30 o sinal tocou e o Participante B foi levado pela professora até o refeitório para tomar café.

...Quando acabou o café a estagiária o levou até o banheiro onde estavam as outras crianças escovando os dentes (...) 
Em relação ao Participante $\mathrm{B}$ em todos os dias da observação a pesquisadora acompanhou o participante B no refeitório no momento do lanche que acontecia as 9: 30 da manhã. Após o lanche a criança era levada pela professora até um banheiro onde realizavam a higienização.

Segundo Mello (2004, 2007), os ambientes da escola poderiam propiciar situações de aprendizagem, desde que com metas específicas. $\mathrm{O}$ ambiente do refeitório poderia beneficiar o participante A o contato com diferentes alunos e demais interlocutores adultos quanto ao vocabulário utilizado na situação, diálogos espontâneos entre as crianças, propiciando não só questões de aprendizagem pedagógica, mas convívio social. Soro-Camats (2003), advertiu a necessidade de inserir as crianças e jovens nas diferentes situações, mas reforçou a importância do ambiente estar adaptado para as necessidades das crianças com deficiência. Os documentos nacionais a respeito de políticas públicas para a inclusão também alertaram a necessidade da adaptação dos ambientes da escola (BRASIL, 2006, 2007).

Nesse contexto, foi possível perceber que o refeitório da escola do participante A não tinha mobiliário adequado a todas as crianças e falta de funcionário capacitado para colaborar e organizar com a professora a atividade da refeição.

Embora tenha sido possível identificar pelo relato do professor, seus registros que o participante A esteve envolvido com tarefas fora da sala de aula, a observação indicou que o aluno permanecia maior parte do tempo na sala de aula. Cabe ressaltar a falta de recursos humanos para deslocar as crianças da classe especial para espaços diversificados da escola para a realização de diferentes tarefas, mas também é importante destacar as condições de saúde da maior parte das crianças da sala do participante A.

Com relação ao participante B foi possível identificar por meio das observações que o aluno tinha ampla possibilidade de participar de tarefas em diferentes espaços. Como já foi descrito anteriormente o participante B era o único aluno com paralisia cerebral. Desta forma, os próprios colegas poderiam auxiliar no deslocamento e nas tarefas propostas.

\subsubsection{Interlocutor mediador do aluno}

O professor tem como meta desenvolver um planejamento que contemple o currículo estabelecido pela escola. Perante o planejamento estabelecido o professor pode organizar sua rotina com objetivos, recursos, estratégias de forma a atingir o resultado esperado pelo 
planejamento. Nesse processo de organização da rotina o professor pode e deve ser o interlocutor de seu planejamento, mas o mediador nas ações pedagógicas.

No que se refere à educação infantil, a função do professor está relacionada com o cuidar e o educar de forma que os alunos possam adquirir novos conhecimentos, vivências e conquistar a aprendizagem significativa (LEONTIEV, 1991; MELLO, 2004, 2007).

Sendo assim, o professor deve conhecer seus alunos no que se refere a habilidades e necessidades para que possa elaborar e organizar sua rotina. Perante a organização da rotina, conhecimento a respeito do desenvolvimento infantil e características de seus alunos, o professor pode selecionar instrumentos ou recursos mais adequados frente aos objetivos préestabelecidos para a mediação da aquisição de habilidades para o processo de aquisição da leitura e escrita.

O professor é o responsável pela interação, contato, envolvimento e, principalmente pela mediação no processo de aprendizagem significativa do aluno na escola (LEONTIEV, 1991).

A literatura também alertou que o professor deve ser o facilitador na aprendizagem do aluno, independente das suas necessidades (MANZINI; DELIBERATO, 2004, 2007; MANZINI, 2005; BRASIL, 2006; PELOSI, 2008, 2009). O envolvimento e capacitação do professor com a organização do planejamento e sua rotina escolar poderão garantir a adequada mediação com o aluno com paralisia cerebral.

A Educação Infantil deve favorecer a criança com deficiência a oportunidade de realizar contatos com diferentes interlocutores e mediadores, entre eles as demais crianças da escola. A escola deve ser um ambiente adequado para favorecer ao aluno com paralisia cerebral novos conhecimentos, ou seja, a troca de experiências significativas não só com o professor mas também o com as demais crianças da escola. Os recursos e estratégias de tecnologia beneficiam a participação do aluno com paralisia cerebral nas atividades junto ao grupo de alunos, esta situação permite a formação de interlocutores mediadores não só para o ambiente escolar, mas para diferentes contextos sociais (MANZINI; DELIBERATO; BRACCIALLI, 2006; VON TEZTCHNER, 2009).

Em relação aos participantes A e B as informações obtidas através da entrevista com a professora e do Protocolo de Identificação de Rotina Escolar foram apontados os seguintes interlocutores mediadores presentes na escola: 
(...) esses dias ele perguntou algo dentro de um contexto para a $\mathrm{M}$ ((professora auxiliar)) ela estava falando sobre um assunto comigo (...)

Professora, duas professoras auxiliares, o motorista da perua durante o transporte e uma ajudante para o transporte.

Participante B

Professor. Quando disponível estagiária que atende a escola.

As professoras dos dois participantes não apontaram durante os exemplos acima as demais crianças da escola como interlocutores mediadores das atividades desenvolvidas. É necessário que o professor entre as atividades propostas ofereça oportunidades para que a criança com paralisia cerebral amplie a sua relação com diferentes interlocutores, entre eles as os alunos da escola. A mediação necessária para os alunos com paralisia cerebral nas atividades poderiam ser feitas por professores, profissionais da escola e alunos competentes em habilidades específicas, como por exemplo, em habilidades motoras para auxiliar o aluno com alteração neuromotoras na realização de uma tarefa que depende de atos motores.

Teixeira; Ariga; Yassuko (2003), Ferland (2006) e Moyles (2006), discutiram que as crianças constroem o conhecimento a partir da relação com as diferentes pessoas, no caso as atividades e as brincadeiras com outras crianças podem favorecer o desenvolvimento da linguagem, a curiosidade, o prazer e a imaginação, compondo a sua inteligência e adquirindo conceitos pré-requisitos para a leitura e escrita.

Outro aspecto importante a ser discutido é a mediação dos alunos com paralisia cerebral ser feito por pessoas não capacitadas, como a estagiária, auxiliar de sala e o motorista, como pode ser observado no exemplo a seguir:

Participante B

$\underline{\text { Ao final da observação a pesquisadora perguntou a professora sobre a }}$ formação da estagiaria e ela disse que a mesma era aluna do $2^{\circ}$ ano de pedagogia, e recebia uma bolsa da prefeitura para auxiliar nas atividades da escola.

A professora do participante $\mathrm{B}$ era a responsável pelo aluno durante todas as atividades e apenas em alguns momentos, contava com uma estagiária, porém ela atendia toda a escola e não apresentava horários fixos disponíveis para a sala de aula do participante B. A 
seguir estão exemplos de participação da estagiária com o professor do participante B:

\section{Participante B}

Quando as crianças foram escovar os dentes o Participante B não os acompanhou pois ainda não havia acabado o lanche, ficando a estagiária responsável em acabar o de dar a alimentação e levá-lo ao banheiro.

(...) em seguida a criança foi levada ate o tanque de areia, permanecendo apoiado na estagiária que acompanhava as crianças...

(...) neste momento a estagiária que esta auxiliando a professora vira a pagina do caderno da criança mais uma vez e deixa em uma pagina em branco $(\ldots)$

Como exemplificado a estagiária participou das atividades em três momentos: no refeitório, na atividade no tanque de areia e em atividade na sala de aula. Foi possível notar através das observações que durante o tempo que a estagiária permaneceu na sala de aula ela acompanhou o participante B e também auxiliou a professora com as outras crianças da sala. Rothschild, Swaine e Norris (2001), discutiram a necessidade de pessoas capacitadas e envolvidas na rotina de sala de aula para colaborar nas tarefas do grupo de alunos e não somente do aluno com deficiência, evidenciando para a sala de aula e seus alunos a existência de diferentes necessidades de auxilio. Embora a participação dos mediadores deva ser para o grupo de alunos da sala de aula, a literatura advertiu a importância das diferenças serem consideradas pelo grupo (PELOSI, 2006; OMOTE, 2004).

Em relação ao Participante A é possível observar no exemplo a seguir a participação de uma das auxiliares de sala durante a atividade de música para auxiliar no posicionamento do aluno:

\section{Participante A}

\section{(...) A professora auxiliar estava cantando junto com as crianças (...)}

(...) a professora pediu ajuda a auxiliar para corrigir a postura do Participante A, esta se dirigiu até o aluno e o colocou novamente sentado na cadeira tipo cantinho (...)

A auxiliar de sala do Participante A também era responsável pela alimentação da criança e as atividades de higienização, assim seguem o conteúdo encontrado na coleta de dados. 


\section{Participante A}

(...) sendo que duas auxiliares ficaram responsáveis em dar comida para as crianças...

Após a refeição a auxiliar levou o participante A ate o banheiro, sendo realizada a higienização das mãos, boca e a troca da fralda.

Para finalizar, o transporte do participante A tanto na chegada quanto na saída da escola era feito por um motorista e uma ajudante, e o Participante B contava apenas com o motorista.

Participante A

(...) o participante A foi colocado na perua com a ajuda do motorista e da ajudante de transporte...

Participante B

(...) neste momento o motorista do ônibus chegou até a sala para buscar o participante B

O participante A era colocado em um veículo escolar em cadeiras próprias para transporte de crianças, e o participante B era colocado no banco do um veículo escolar apenas com o cinto de segurança.

Em relação ao número de pessoas responsáveis pela sala pode-se observar que o participante $\mathrm{A}$ tem contato com um maior número de profissionais do que o participante $\mathrm{B}$, já que além das duas auxiliares que acompanhavam a sua professora durante as atividades, a sala especial contava com a colaboração de profissionais da saúde. A literatura da área advertiu a necessidade de capacitar os diferentes interlocutores e mediadores para favorecer o uso adequado dos recursos e estratégias da tecnologia assistiva (MANZINI, 2005; MANZINI; DELIBERATO, 2004, 2007; PELOSI, 2008, 2009).

Nesse contexto de discussão, a estagiária, o motorista e auxiliar de sala poderiam ser mediadores no processo de ensino dos diferentes alunos em função das tarefas estabelecidas na rotina.

A professora do participante A designou profissionais da escola como interlocutores mediadores durante as atividades, porém durante a observação foi possível identificar que a professora era a mediadora das atividades e os demais profissionais apoiavam a professora colaborando com o manuseio das crianças. O comprometimento motor dos alunos da classe especial demandam um maior número de pessoas envolvidas nas estratégias para o controle 
postural dos alunos, uma vez que a postura adequada favorece a atenção e o manuseio dos recursos em sala de aula (BERSH, 2008, OLIVEIRA, 2007; BRACCIALLI et al., 2008; BRACCIALLI, 2009).

O processo de observação novamente foi fundamental para concluir o conteúdo desta categoria, permitindo ao pesquisador evidenciar os interlocutores mediadores e suas ações. Assim, foi possível constatar que a professora responsável pela sala, dirigia as atividades e desenvolvia conteúdos pedagógicos estabelecidos por ela, através de atividades direcionadas e dirigidas as necessidades de cada aluno. Segue o conteúdo das observações realizadas:

Participante A

(...) a professora se dirigiu até a criança cantando individualmente a musica com o nome dela ...

(...) a criança cantou junto à professora os trechos que ele tinha que responder...

Participante B

A professora neste instante chega e abaixa do lado direito da carteira da criança...

A professora coloca novamente o lápis em cima do caderno do Participante B e vai em direção a outra aluna que deixou o lápis cair no chão...

(...) a professora lê um livro de historia em pé para todos...

$\underline{\text { Após o ensaio a professora levou as crianças para a sala de vídeo }}$

Em Brasil (2004), discutiu-se a necessidade do suporte para o professor do ensino regular que recebe alunos com necessidades educacionais especiais em sua sala de aula. Este suporte deve ser ministrado pela Coordenação Pedagógica, que deve ser ativa e participante no cotidiano da sala de aula, da escola e das relações com a comunidade.

O participante A que frequentava a sala especial para alunos com deficiência física tinha uma professora com formação em Pedagogia e habilitação em deficiência física, o mesmo referiu ter 23 anos de experiência como professora, sendo que nos últimos 15 anos vêm trabalhando com crianças com deficiência física. Já a professora do participante B, que frequentava a sala regular tinha formação em Pedagogia e Artes e 16 anos de experiência como professora da Educação Infantil. A professora relatou não ter feito cursos de capacitação para atender alunos com deficiências e, o participante B foi o primeiro aluno que recebeu na sua sala. Segundo a professora do participante B ela não conta com apoio sistematizado de profissionais especializados. 
Segundo Brasil (2001), o serviço de apoio pedagógico especializado deve ocorrer no espaço escolar e se efetiva através do trabalho em equipe envolvendo os professores da classe comum com os da educação especial para o atendimento das necessidades educacionais especiais dos alunos durante o processo de ensino e aprendizagem. Embora o apoio especializado seja um indicativo dos documentos nacionais, as escolas e os professores do ensino regular não contam com ações de programas sistematizados envolvendo equipe de profissionais da saúde e recursos de tecnologias assistivas para suas salas de aulas com as devidas manutenções (BEUKELMAN; MIRENDA, 2007; DELIBERATO, 2009a; BERSH, 2009; PELOSI, 2009; ARAUJO; DELIBERATO; BRACCIALLI, 2009).

\subsubsection{Recursos}

Nessa categoria estão os resultados e discussão a respeito de recursos da escola e recursos adaptados, como definido anteriormente.

Os recursos oferecidos às crianças com paralisia cerebral podem ser fundamentais não só para as questões da aprendizagem escolar, mas também para o seu desenvolvimento global. Em função das diversas alterações que uma aluno com paralisia cerebral possa ter, como alterações sensoriais, perceptuais, motoras, linguagem e cognitivas, os materiais devem possuir características especificas e serem atraentes para possibilitarem um uso funcional (BESIO, 2002; ARAUJO; MANNZINI, 2001; MANZINI, 2005).

O recurso adequado às especificidades dos alunos com paralisia cerebral é fundamental para sua participação efetiva na atividade proposta, sendo de responsabilidade da escola oferecer ao aluno com necessidades educacionais especiais os recursos adequados (BRASIL, 2006, 2007).

Durante a Tarefa 1 o pesquisador procurou identificar quais recursos eram utilizados no contexto escolar e quais eram os recursos preferidos da criança. Também foram identificados os recursos adaptados utilizados pela criança na escola.

Entre os recursos mais utilizados na escola pelas professoras foram citados no Protocolo de Identificação da Rotina Escolar os seguintes objetos: 
Bolas, carrinhos e bonecas, CDs de musica, baldinhos e pazinhas para areia, DVDs infantis

Participante B

Baldinhos, pazinhas, peneiras, escorregador, gira gira, ponte, balanço, gangorra, gaiola, papel bobina, caderno de linha, lápis, estojo, lousa, giz, apagador, texto digitado, tesoura, cola, bola, corda, livros, folhetos, aparelho de som, CDs, caderno de música,DVDs, fitas de vídeo, livros, fantoches, albúm seriado, carrinhos, bonecas, papeis diversos, lápis de cor, giz de cera, sucatas, bambolê e bastões.

Os dados foram complementados com as informações da entrevista:

Participante A

... o PA++ gosta bastante de atividades com bola carri::nho ++ principalmente com bola + brinca com o baldinho na areia ....

... colocamos DVD de música ... ele canta e mostra bastante interesse nas musicas...

...Ele gosta muito de bola $+\ldots++$ quando tem musica ele gosta muito ++ acho que brincadeiras são essas + A:H tem a areia também e as brincadeiras com as crianças das outras salas...

....A BOLA + ele gosta muito de (...) quando ele houve a musica sobre a bola " ele na pede a bola e quer brincar...

Participante B

...++ a bola a corda + nos temos o bambolê + os jogos de montar né + os jogos que eu confecciono com su:cata + são os brinquedos que mais a gente usa.

...o de mais interesse é o da casinha...

Em relação aos ambientes externos, ou seja, fora da sala de aula, nas atividades planejadas pela professora foram identificados os seguintes recursos:

Participante A

(...) a professora ajudou o participante A. a encher o balde para fazer um "bolo" de areia (...)

(...) a auxiliar buscou um balde de água e jogou na areia próximo aos pés do participante $A(\ldots)$

Participante B 
O participante B foi retirado do andador e levado ate o tanque de areia, em seguida com o pé tentou manipular a pá de areia e levar até o balde (...)

(...) a estagiária ajudava a criança movimentando sua mão para realizar os movimentos necessários e a manipular os brinquedos do tanque de areia (pá e balde).

(...) o Participante B estava em um quiosque, cantando a música de chegada, enquanto circulava com um andador favorecendo padrões patológicos de movimentos (...)

(...) no campo o participante B se locomoveu através do andador em direção ao brinquedo (bola) que estava com a amiga (...)

(...) foi até a quadra da escola através do seu andador para junto com as outras salas da escola ensaiar uma música para a inauguração da quadra esportiva (...)

O participante A realizava atividades na areia, porém não tinha autonomia para utilizar os recursos que estavam disponíveis nesse momento. $\mathrm{Na}$ atividade no tanque de areia o Participante B foi retirado do andador, sendo auxiliado pela estagiária durante toda atividade para que pudesse manipular e segurar os recursos.

Entre as atividades realizadas em sala de aula foi observado que embora os recursos estivessem presentes na sala de aula, ambos participantes não tinham como ter acesso ao seu uso. Segue exemplos dos recursos utilizados nas tarefas em sala de aula:

\section{Participante A}

Recurso: bola

(...) passava bolas de diferentes tamanhos e cores (...)

Recurso: carrinhos

(...) a professora tentou colocar o carrinho na mão do participante A e junto com ele passou a manusear o carrinho por varias direções (...)

Recurso: guache e cartolina

(...) uma atividade de pintura com guache em cartolina (...)

\section{Participante B}

Recurso: palitos, caderno, lápis

$O$ participante $B$ deixa os palitos caírem da mão no chão, permanecendo apenas com um na mão, e a estagiaria deslocando o seu andador para trás diz:

Estagiaria: Espera ai, deixa eu virar o seu carrinho.

Neste momento a estagiaria se posiciona do lado esquerdo da cadeira A2, coloca os palitos em sua própria mão, leva até a mesa de apoio do andador próximo a mão direita da criança e diz:

Estagiaria: Tira três 
A2 com a mão direita retira dois palitos da mão da estagiaria e ela então diz:

Estagiaria: Dois, tira mais um

$O$ participante $B$ leva a mão direita ate a mão da estagiaria e tira mais um palito, neste momento a estagiaria sem mostrar os palitos que sobraram em sua mão para a criança diz:

M2: Tinha sete tira três, sobram quatro

A estagiaria pega o lápis e em silêncio escreve o resultado no caderno da criança que esta posicionado na carteira, longe da visão dele e sem que o participante B participasse da ação.

Em relação ao participante A os recursos convencionais como brinquedos, materiais escolares, utensílios para atividades de vida diária estavam disponíveis na escola e são necessários para a Educação Infantil. Devido ao número de crianças com deficiência física da sala (nove) e as suas diferentes especificidades, estes recursos não contemplaram as necessidades do participante $\mathrm{A}$ e, com isto, não permitiram sua participação nas tarefas propostas pelo planejamento.

Em função da falta de recursos adaptados para o participante A e os demais alunos, a professora utiliza o brincar (atividade) como recurso pedagógico. Todos os brinquedos e demais recursos citados estavam inseridos em um contexto de brincadeiras próprias da faixa etária do aluno como das demais crianças da sala. Embora a professora tenha utilizado o brinquedo e a brincadeira como instrumento pedagógico, o participante A necessitava de auxilio para o manuseio, ou seja, o aluno era dependente da mediação do professor para o uso do material.

Ferland (2006) e Blanche (2000, 2002), discutiram que o brincar é essencial para o desenvolvimento da criança, e é uma atividade de fácil acesso para as crianças típicas, porém a criança com deficiência física necessita de recursos específicos que favoreçam o brincar em seus ambientes naturais. Soro-Camats (2003) e Pelosi (2003) discutiram a necessidade de adaptação de brinquedos de baixa ou alta tecnologia para que as crianças com diferentes alterações motoras tivessem autonomia no uso e na participação com as demais crianças.

Durante as observações realizadas com o participante B em sala de aula foi possível observar o uso de caderno, lápis, cola, tesoura e palitos de sorvete. Em todas as tarefas nas quais o aluno necessitou destes objetos, foi necessário auxilio permanente da professora ou da estagiária. É possível identificar que o participante B, sem a presença dos materiais escolares adaptados ou adequados a sua condição motora não tem independência para participar de uma atividade pedagógica proposta em sala de aula.

Em relação aos recursos adaptados presentes na escola foram identificados os seguintes exemplos: 


\section{Participante A}

(...) o participante A só utiliza a órtese do pé + ele trás para escola + mas em brinquedos ou outro material escolar não (...)

(...) não tem nada especifico para ele + ai fica difícil + mesmo que eu saiba qual a melhor posição fica difícil ++ eu sei que é preciso improvisar + "mas sempre + e com o material que temos é difícil ++ almofada travesseiros + ele (( o P1)) é muito pequeno + precisa de algo especifico para ele ++ da para improvisar quando temos um material próximo do que a criança precisa + ai você improvisa uns $20 \%$ + não é o correto mas fica bom + agora quando você tem que improvisar $50+60 \%$ para o material dar certo fica difí:cil ++ nossa maior dificuldade é de posicionar corretamente + pela falta de material especifico para o P1 e a dificuldade motora dele (...)

(...) teve uma pulseira palmar para usar com lápis colher que umas meninas do curso de T O ((terapia ocupacional)) lá da UNESP ++ então elas fizeram uma pulseira + mas não deu certo + ficou grande ai ele não usa ++ precisa ser feito algo para ELE ++ especifico ++ mas essa não foi feita ++ é grande (...)

\section{Participante B}

Não existe nada adaptado para ele na escola, ele realiza as atividades como as outras crianças +++ modifico só a maneira de fazer ++ ah... tem um copo que a mãe mandou.

Por meio dos exemplos citados é possível notar que o Participante A tem acesso a uso de recursos de tecnologia assistiva, como no caso, da órtese e da pulseira palmar. Embora a professora deste participante não tenha pontuado mobiliário adaptado para este aluno, como no caso da cadeira de roda adaptada para as medidas e características motoras especificas do aluno, ela conseguiu realizar adaptações na cadeira de rodas já existente com almofadas. O tipo de capacitação de professores para trabalhar com alunos com deficiência tem sido tema de discussão em fóruns, congressos e pesquisas (NÓVOA, 1995; MANZINI, 1999; OLIVETO; MANZINI, 1999; SODRÉ; PLETSCH; BRAUN, 2003; BRACCIALLI; 2008; PELOSI, 2006).

A adaptação realizada na cadeira de rodas foi uma estratégia utilizada pela professora para ampliar as possibilidades de participação do aluno A na tarefa proposta. A estratégia utilizada pela professora foi possível em virtude não só da sua experiência com alunos com deficiência, mas pelo curso de capacitação na área da deficiência física por ela realizado habilitação em educação especial - área da deficiência física.

A professora do participante $B$ relatou não utilizar recursos adaptados, embora tenha indicado a necessidade de adaptar a atividade. No exemplo a seguir é possível notar que este 
participante necessita de auxilio da mediação do interlocutor mesmo na atividade de vida diária, como nas refeições por não ter recursos adaptados para a tarefa:

\section{Participante B}

Neste momento tomou chá com bolachas, o chá foi dado a ele em uma caneca comum com auxilio total da estagiária, as bolachas também eram colocadas na boca da criança.

A atividade do refeitório foi novamente observada, após ser introduzido um copo com adequações fornecido pela família:

\section{Participante B}

A professora mostrou para a pesquisadora um copo de bico trazido para escola pela mãe, em seguida demonstrando como a criança era alimentada, $\underline{\text { sendo oferecido suco no copo com bico }}$

O exemplo citado pode ilustrar a necessidade do uso de recursos não só para a participação das tarefas, mas para proporcionar autonomia e independência para o aluno e consequentemente melhor qualidade de vida (SORO-CAMATS, 2003; PELOSI, 2008, 2009; BERSH, 2009).

Por meio dos exemplos expostos é possível refletir que a classe especial poderia oferecer recursos adaptados e serviço especializado para o participante A e, assim garantir maior participação do aluno na rotina escolar com qualidade. A escola do participante B não tem apoio de serviço especializado, como classe especial ou sala de recursos ou ainda professor com qualificação e capacitação para direcionar as adaptações. Apesar de existir ampla discussão a respeito da interferência do ambiente segregado e inclusivo nas questões do uso da tecnologia assistiva, não há pesquisas que comprovem a eficácia da modalidade de ensino no uso generalizado dos recursos (SOTO; VON TETZCHNER, 2003).

Von Teztchner et al (2005), discutiu que o ensino especial pode oferecer recursos, mas o aluno com deficiência no ensino especial pode não ter vivências para o suporte necessário para a generalização do seu aprendizado.

Em relação ao participante $\mathrm{B}$ a escola não ofereceu recursos adaptados durante as atividades da criança. Apesar de ter acesso a um maior número de locais em sua escola, e a professora inserir materiais nas tarefas, o aluno não teve acesso as oportunidades oferecidas em virtude da falta de acessibilidade: recursos não adaptados, falta de auxilio de um professor de apoio e o tempo disponível do professor para a mediação necessária. Os pesquisadores 
estão preocupados em alertar que são necessárias ações para capacitar o professor, mas sem os recursos de tecnologia assitiva ficaria difícil o professor realizar a mediação de forma adequada. Por outro lado, os autores também alertaram que introduzir recursos adaptados sem a capacitação e envolvimento do professor, as ações inclusivas também poderiam não ser efetivas para os alunos com deficiência (DELIBERATO; MANZINI, 2007; DELIBERATO, 2009; PELOSI, 2009; ARAUJO; DELIBERATO; BRACCIALLI, 2009).

Nos últimos anos tem sido possível observar ênfase quanto aos aspectos ergonômicos dos mobiliários escolares, principalmente ao se deparar com alunos com deficiência física. É fundamental para criança deficiente física o posicionamento adequado através de recursos específicos que atendam as suas necessidades posturais, ou seja, assentos e encostos que promovam alinhamento estabilidade e conforto (BRASIL, 2007; BRACCIALLI; MANZINI; VILARTA, 2005; BERSH, 2006; BEUKELMAN; MIRENDA, 2007; BRACCIALLI et al. 2008; BRACCIALLI, 2009).

O professor pode utilizar de soluções simples como o apoio de almofadas, cintos, apoios de cabeça, apoio para os pés, assentos antiderrapantes e contenções laterais. Estes pequenos ajustes permitirão ao aluno uma postura adequada e confortável, o que possibilita melhores condições de aprendizagem (RADELL, 1996; BERSH, 2006; BEUKELMAN; MIRENDA, 2007; BRACCIALLI et al., 2008).

Ao posicionar corretamente a criança com paralisia cerebral o professor poderia proporcionar a criança mudança na postura, uma ampliação do seu campo visual, permitindo um melhor contato e seguimento visual do espaço e consequentemente ampliação na participação das tarefas pedagógicas.

A escola do participante A oferecia possibilidades de recursos para posicionamento como: cadeiras de madeiras adaptadas, cadeiras de rodas adaptadas, cadeiras tipo cantinho, mesas com ajustes, mesas inclinadas, calça da vovó, rolos e almofadas para posicionamento,conforme demonstra observação a seguir:

\section{Participante A}

(...) estava sentado em uma cadeira (tipo cantinho), com algumas almofadas apoiando (...)

(...) a criança foi posicionada em cadeira de madeira adaptada, com bandeja em formato de $U$ para fazer a refeição (...)

O participante estava deitado em uma calça da vovô (...) 
A cadeira do PA foi forrado com dois travesseiros a fim de conseguir um melhor posicionamento.

Durante a observação foi identificado um número restrito de recursos utilizado pelo participante A, e grande parte deles foram recursos utilizados para posicionamento.

Em relação ao participante $\mathrm{B}$, o recurso para o posicionamento era um andador com estrutura em aço, assento tipo fraldão e mesa de apoio para atividades. $\mathrm{O}$ andador era trazido de casa todos os dias. Apesar de o andador ser de uso pessoal do aluno ele não estava adequado para as suas necessidades, pois necessitava de ajustes ergonômicos, como pode ser observado pelo exemplo a seguir:

\section{Participante B}

(...) o participante B esta posicionado em seu andador em frente a mesa de sala de aula comum, esta com os joelhos semi fletidos e membros superiores sobre a mesa de atividades do andador, e com a cabeça baixa apoiada sobre os braços.

No momento em que a professora se aproxima do andador, o Participante B se desestabiliza, iniciando uma sequência de movimentos involuntários. Através dos movimentos dos pés desloca o andador para trás sem a intenção de realizar esta ação, desloca o todo o corpo para a esquerda e continua uma sequência de movimentos involuntários.

Além do andador do aluno a escola tinha uma cadeira de rodas de madeira com mesa de apoio, mas o participante B não a utilizava, pois segundo a professora e a diretora ele não aceitava permanecer no equipamento.

$\mathrm{O}$ andador utilizado pelo Participante B permitia que ele se deslocasse pelo ambiente, porém para que isto acontecesse muitas vezes realizava movimentos inadequados, principalmente de pernas e braços, estimulados pela persistência dos reflexos primitivos (GAUZZI; FONSECA, 2004; SCHWARTZWAN, 2004).

Durante as atividades também foi possível observar que o uso deste recurso não era adequado, porque estimulava os movimentos involuntários e variações na tonicidade muscular, dificultando os movimentos que a criança pretendia executar e consequentemente sua funcionalidade. Nas atividades observadas nos ambientes externos da escola a criança se locomovia e permanecia durante todo o tempo no andador.

As referências da literatura apontaram que adequando a postura das crianças com paralisia cerebral, dando-lhes pontos de apoio e estabilidade, é possível melhorar as alterações 
de tônus muscular e diminuir os movimentos involuntários e, com isso, oferecer condições para que o aluno possa atuar sobre objetos e materiais escolares; consequentemente poderá permanecer com melhor contato e seguimento visual do espaço e sua atenção poderá estar direcionada para atividade mais complexas (RADELL, 1996; BRACCIALLI; MANZINI, VILARTA, 2005; BEUKELMAN; MIRENDA，2007; BRASIL，2007; BERSH, 2008; BRACCIALLI et al., 2008).

\subsubsection{Estratégias}

Segundo políticas públicas, para a educação do aluno com deficiência física na escola são necessários recursos e estratégias que favoreçam seu processo de aprendizagem e os habilite funcionalmente na realização das tarefas escolares (BRASIL, 2006).

Os pesquisadores da área da educação especial e da tecnologia assistiva também discutiram que os alunos com paralisia cerebral precisam de recursos adaptados a suas habilidades e necessidades. As pesquisas de Barnes e Turnes (2001); Pelosi (2003, 2008); Copley e Ziviani (2004); Deliberato (2005, 2007); Audi, 2006; Deliberato et al (2009); Braccialli et al. (2008); descreveram recursos e estratégias para os alunos com paralisia cerebral e, também alertaram que embora a estrutura do programa implementado na escola possa ser o mesmo para os alunos com paralisia cerebral, os recursos e as estratégias deveriam ser adaptados para cada aluno.

$\mathrm{Na}$ tarefa 1 desta pesquisa foram identificadas atividades realizadas na rotina dos alunos por meio do Protocolo de Identificação da Rotina Escolar para que fosse possível gerar ideias do recurso de tecnologia necessário aos Participantes deste estudo:

\section{Participante A}

Hora social, brincadeiras com bola, brincadeiras com carrinhos e bonecas, atividades com musica, atividades de pintura, contos com livro de historia, filmes em DVD, brincadeiras na areia e no parque.

Participante B

Brincadeiras livres, brincadeiras com regras, organização de texto em painel, leitura e escrita de palavras, atividades musicais, organização de texto, leitura de texto, assistir filmes, cruzadinhas, caça palavras, quebra cabeça, recorte e colagem, atividades de matemática, contagem, jogos de regras, leitura de livros, hora da casinha e atividades de artes. 
Além das atividades descritas, as professoras também descreveram durante a entrevista as estratégias para garantir o acesso da criança nas atividades propostas. A seguir é possível observar exemplos das estratégias utilizadas para envolver e facilitar a participação dos alunos.

\section{Participante A}

(...) em seguida professora movimentou sua articulação do punho e abriu a mão, neste momento colocou o carrinho na mão da criança e, junto com ela a manuseou imitando o barulho de um carro (...)

\section{Participante B}

(...) na sala quando eu dou a brincadeira da casinha a gente envolve ele com os brinquedos + só que a gente le:va os brinquedos ate ele ++ mas ele por exemplo ele adora cozinhar + então é o fogaozinho e as panelinhas + e ele pede para agente estar colocando a terrinha a folhinha representando o que ele esta fazendo (...)

(...) eu fazia muito com ele uma brincadeira que se chamava acorda urso né + que é assim + uma criança fica no meio da roda fazendo de conta que esta dormindo e as outras chegam de mansinho e falam aco:rda urso + então ele amava essa brincadeira + que era uma brincadeira que ele podia ser tanto o urso como ser o pegador + entendeu? + ele podia participar com as crianças correndo atrás dele para pegar (...)

(...) brincadeira de roda ele participava porque as crianças conseguiam levá-lo na roda + tem também uma brincadeira que eles gostavam que é se eu fosse um peixinho e soubesse nadar + primeiro a gente jogava na roda e depois tirava + então ele participava bastante também desta brincadeira (...)

(...) nas brincadeiras e às vezes eu mudava alguma regra em função dele né + ter justamente o cuidado no correr + delimitava o espaço para não ir muito longe porque eu sabia que ele não poderia ir muito alem daquilo + então de estar mudando algumas regrinhas ++ mas todas as coisas ali dentro do que eu sabia que ele poderia fazer (...)

Nas estratégias referidas pelas professoras durante a entrevista e identificadas pelo pesquisador durante a observação foi possível verificar que realizam modificações nas regras ou formas de conduzir as brincadeiras a fim de ajustá-las as necessidades dos participantes. Essa prática é pertinente ao que existe em literatura e nas pesquisas nacionais e internacionais, alertando que a adequação das atividades às necessidades do aluno com deficiência física 
possibilita a autonomia, a segurança e a comunicação para que eles possam estar inseridos em turmas do ensino regular (GLENNEN, 1997; EDYBURN, 2000; SOTO; VON TETZCHNER, 2003; CRUZ, 2006; BEUKELMAN, MIRENDA, 2007; BRASIL, 2007; HUANG; SUGDEN; BEVERIDGE, 2009).

Muitas vezes o professor tem a intenção de desenvolver estratégias adequadas, porém encontra dificuldade devido ao comprometimento da criança, ou recursos que não atendem as necessidades especificas do aluno (STEELMAN, 2002).

Pode -se observar um exemplo dessa situação nas informações da professora do participante A, quando a mesma se refere que apesar de ter tentado utilizar a órtese (recurso) não conseguiu promover a participação e o bom desempenho da criança. Essa situação exemplificou que embora a professora tivesse os recursos de tecnologia assistiva, não conseguiu introduzir uma estratégia que viabilizasse o seu uso. Esta informação reforça a necessidade e a importância de o professor estar atento para que a tecnologia assitiva contemple os recursos, estratégias e serviços (COPLEY, ZIVIANI, 2004; BERSCH, 2006; GUARDA, DELIBERATO, 2006; JUDGE，2006; OKOLO; BOUCK ， 2007; JUDGE; FLOYD; JEFFS, 2008; ROCHA et al., 2008, ROCHA; DELIBERATO, 2009a, 2009b; PELOSI, 2006, 2008, 2009; GALVÃO FILHO, 2009).

A literatura nacional e internacional através de estudos realizados por autores como Rothschild, Swaine e Norris (2001); Steelman (2002); Deliberato (2005, 2007, 2008, 2009); Pelosi (2006, 2008, 2009); e Beukelman e Mirenda (2007), já disctiu a necessidade de programas de intervenção na escola por meio de atuações colaborativas entre os profissionais da educação e da saúde para a efetiva participação dos alunos com paralisia cerebral na escola, quer ambiente inclusivo ou no ambiente segregado. Nas pesquisas realizadas pelos autores foi possível perceber a importância do professor estar envolvido com etapas de atuação sistematizada para refletir a respeito dos recursos e estratégias necessárias.

É necessário utilizar estratégias apropriadas a fim de favorecer a mediação entre as atividades e o aluno com deficiência física. Durante a observação foi possível identificar a intenção da professora em oferecer estratégias que pudessem permitir aos participantes a participação nas atividades propostas. A seguir serão citados exemplos de atividades:

\section{Participante A}

Atividade com música:

(...) ao cantar a professora passa de criança em criança realizando movimentos com as pernas, braços e pé, conforme a letra da música... 
...durante a música de a professora se dirigiu a cada criança e cantava individualmente com o nome dela (...)

Durante a música a professora ajudou o PA da sala especial a realizar alguns movimentos de braços e pernas.

Atividade com bola:

(...) então quando brincamos de passa a bola ele gosta muito + ou de brincar de passar outros brinquedos (...)

(...) a auxiliar e foi ate o Davi mostrando a bola grande e a bola pequena, pegando nos braços e abrindo a mão do Davi colocou a bola em seu colo e pediu para que joga-se.

Tanque de areia:

(...) através de movimentação passiva (professora pegando o seu braço e levando ate o baldinho) o participante A pegou a pazinha e levou areia ate o baldinho.

(...) foi levado uma almofada de courvim para apoio no do aluno na cadeira durante atividade no tanque de areia, porém não foi totalmente adequado sendo necessário a professora sentar ao lado e dar apoio com o braço.

Atividade de pintura

(...) ele se encontrava em uma cadeira de madeira, com apoio de travesseiros e também sendo sustentado pela bandeja de atividades, pois a cadeira era grande para ele. A professora ficou em pé do seu lado, tentou esticar o braço e abrir a mão do paciente, porém o mesmo apresentou bastante resistência ao movimento, estabelecendo padrão flexor...

...Após algumas tentativas ainda com flexão de cotovelo a professora conseguiu abrir a mão (esquerda) e passar guache na mesma com um pincel, em seguida apertou a mão da criança sobre a cartolina (...)

Participante B

Atividade em sala de vídeo

... durante o filme o participante $\mathrm{B}$ se deslocou através de movimentos involuntários pela sala de vídeo com o andador, após algum tempo a professora o pegou pelo andador e o levou para perto da televisão, segurando o equipamento para que ele não saísse do local...

Atividade em sala de aula

(...) A professora colocou uma das alunas da sala para sentar ao lado do Participante B, em seguida deu uma folha de sulfite que continham quatro figuras de animais, e quadrados com letras também em folha de sulfite que completariam o nome dos animais(...).

Atividade de cabeçalho em sala de aula:

(...) enquanto isto o Participante B permanece na cadeira e a estagiaria com o lápis que pegou do estojo do aluno escreve o cabeçalho no caderno dele que esta sobre a carteira. Neste momento a estagiaria não estabelece nenhum contato com a criança, que direciona o olhar para o lado contrario de onde se encontra o caderno (...) 
(...) em seguida a professora pega novamente o lápis e começa a escrever no caderno de A2 que esta em cima da carteira dizendo:

M2: Marília, que dia é hoje?

Não é possivel compreender o que o aluno diz e a professora então fala:

M2: Vinte. De que mês? Ou... ou...tubro...outubro de 2008. Ontem foi domingo, dia da casa da avó, e hoje que dia que é, que dia que é hoje, há? É segunda feira, hoje é segunda feira, e como esta o dia hoje, ensolarado. Em seguida a professora escreve todas as informações no caderno do Participante $B$ e quando acaba de escrever pega a fralda que esta no andador e limpa novamente a boca.

Atividade de matemática:

A estagiária pega os palitos novamente em sua mão, leva ate a mesa de apoio próximo a mão direita da criança e diz:

Estagiaria: Tira dois, tira dois para a tia

A criança joga a cabeça para trás e sem olhar leva a mão direita até a mão da estagiaria e tira um palito. A estagiaria então diz:

Estagiaria: Mais um

$O$ participante $B$ leva novamente a mão direita e retira o palito, a estagiaria então espalha os palitos de sorvete na mão e diz:

Estagiaria: Quantos ficaram? Conta para tia? Quanto?

A criança emite alguns sons que a estagiaria não compreende e ela diz:

Estagiaria: Quantos palitos têm aqui na mãozinha da tia?

A criança emite sons que ela não compreende e ela diz:

Estagiaria: Ah

A criança emite som que não foi possível compreender na filmagem e a estagiária pega o lápis e em silêncio escreve o resultado no caderno da criança que se encontra em cima da carteira.

A2 percebe que a estagiaria esta utilizando o lápis e logo que a mesma o deixa em cima da carteira ele estende o braço e tenta pega-lo, porém não consegue.

Durante todos os exemplos do participante A, a professora procurou desenvolver estratégias que garantissem a participação do aluno nas atividades. Nessa perspectiva, o professor é mediador entre as crianças e o objeto de conhecimento, ele deve organizar e propiciar espaços e situações de aprendizagens que articulem os recursos a suas e capacidades motoras, afetivas, emocionais, sociais e cognitivas (BRASIL, 1998).

O professor deve fornecer ao aluno estratégias com o objetivo de garantir um ambiente propicio e prazeroso para o desenvolvimento do seu potencial e consequentemente do seu processo de aprendizagem (BESIO, 2002; SORO-CAMATS, 2003; BASIL, 2003; JOHNSTON; EVANS, 2005; BERSH, 2008).

$\mathrm{Na}$ atividade do participante $\mathrm{B}$ na sala de vídeo, o mobiliário inadequado não proporcionou ao aluno condições favoráveis para participar da atividade como as demais crianças de sua sala. Nessa situação a professora necessitou prestar mediação em tempo integral para o aluno segurando o equipamento para que o mesmo pudesse assistir ao filme. Embora esta estratégia tenha dificultado a professora na mediação com as outras crianças, foi 
a única possibilidade de acessibilidade oferecida para o aluno com paralisia cerebral para participar da atividade proposta. Capovilla (2001), discutiu a necessidade de instrumentalizar alunos com deficiência motora e da fala para que pudessem participar na escola de forma significativa. O mesmo autor também alertou que os professores também fossem adequadamente instrumentalizados para ensinar e avaliar seus alunos com deficiência.

Outra estratégia utilizada pela professora do participante B foi colocar o aluno com paralisia cerebral junto à outra criança da sala. Esta pode ser uma estratégia eficiente, pois favorece a participação do aluno na atividade além de estimular a sua interação com as demais crianças. Porém, o professor deve continuar atento, pois o aluno não pode apenas acompanhar a atividade, mas sim deve ter recursos que favoreçam suas condições motoras, comunicativas e perceptivas, ou seja, deve ser um participante ativo desenvolvendo suas habilidades junto com a outra criança (PELOSI, 2006).

Von Teztchner (2009) discutiu o suporte oferecido pelo ambiente para favorecer o aprendizado do aluno com deficiência. Nesse ambiente, o autor discutiu que o suporte de crianças competentes em determinadas habilidades poderiam viabilizar a participação do aluno com deficiência nas tarefas da escola, mas também poderiam ser interlocutores mediadores em outros ambientes, oferecendo possibilidades do aluno com deficiência generalizar o uso de recursos de tecnologia assistiva em locais distintos da escola, como no caso do uso de sistemas de comunicação gráfica.

Nos exemplos citados foi possível perceber que embora o aluno com paralisia cerebral tenha participado das tarefas, os recursos existentes nas escolas dos participantes A e B foram escassos; não contribuindo desta forma com a ampliação da autonomia e funcionalidade da ação utilizada por eles.

Segundo Blanche (2000, 2002); a falta do recurso adequado além de diminuir as possibilidades de estratégias, pode trazer a insegurança do professor em atuar e oferecer ao aluno com paralisia cerebral condições adequadas para o seu aprendizado. Outra situação importante observada quanto à adequação de recursos para propor estratégias adequadas foi em relação ao parque da escola:

\section{Participante B}

....o parque + é como eu já expliquei a gente não tem um brinquedo próprio para ele + então é a insegurança MINHA de estar colocando ele num brinquedo + porque toda vez que eu colocava eu teria que ficar segurando + quer dizer + na verdade ele brincava comigo porque eu que tinha que segurar + eu não poderia deixá-lo solto + e falta nos temos a necessidade de um brinquedo adaptado para ele ++ então toda vez que eu ia pro parque, 
então o que eu fazia, ele ficava comigo sentadinho nas areias do parque + a estagiaria tomando conta das demais crianças e ele brincando comigo na areia + porque os brinquedos não são próprios para ele ta.

Embora a literatura nos indique a necessidade dos parques serem adaptados seguindo normas específicas (LAUFER, 2001; ABNT, 2004), a rotina de brincadeiras das crianças nos parques das escolas pode gerar angustia para os professores frente às questões de perigo para as diferentes crianças e, principalmente ao os alunos com paralisia cerebral. Perante tal situação a professora pode desistir ou mudar a atividade proposta no parque, como foi evidenciado no exemplo acima citado.

Em outras situações é necessário cuidar para que as expectativas negativas em relação ao desempenho das crianças com paralisia cerebral não impeçam que o mediador da atividade ofereça estratégias para que ela tenha o mínimo de autonomia possível. Esse fato pode ser percebebido no momento da atividade de alimentação do participante A acompanhada pela auxiliar da sala:

\section{Participante A}

...a auxiliar colocou uma cadeira na frente da criança, colocou o prato na mesa que estava em sua frente e deu a comida sem que o participante A lhe ajudasse em nenhum momento...

No exemplo acima a auxiliar de sala ofereceu a comida ao participante A sem nenhum procedimento que pudesse favorecer sua participação. Profissionais da área da saúde alertam a respeito dos cuidados necessários com a alimentação dos alunos com deficiência física que possam apresentar alterações nas funções neuro vegetativa, como no caso da sucção, mastigação e deglutição (SILVA, 2007, 2009, COLA et al., 2009, 2010).

Neste contexto de discussão seria necessário que o professor e os demais profissionais atuantes com os alunos com paralisia cerebral estejam capacitados e dispostos para desenvolver estratégias a fim de otimizar a participação do aluno e assim favorecer ferramentas para ampliar suas habilidades motoras, comunicativas, perceptivas e sociais (PARETTE; BROTHERSON; HUER, 2000; LAHM; SIZEMORE, 2002, PELOSI, 2008; DELIBERATO, 2009a, 2009b; ROCHA; DELIBERATO, 2009a, 2009b; SAMESHIMA; DELIBERATO, 2009a).

Embora seja necessário reconhecer que as crianças com deficiência física tenham suas necessidades individuais a escola é responsável em oferecer recursos e estratégias que viabilizem o seu aprendizado (JUDGE; FLOYD; JEFFS, 2008). 


\subsubsection{Participação do aluno nas atividades}

As crianças com paralisia cerebral devem ter a oportunidade de participar numa base de igualdade a seus pares no contexto escolar.

Durante os procedimentos da Tarefa 1 foi possível observar habilidades e diferentes necessidades dos Participantes A e B, como por exemplo, alterações motoras, perceptivas e comunicativas que dificultaram a participação efetiva nas atividades propostas pela professora.

Durante a entrevista as professoras relataram que as crianças participaram das atividades, apresentaram interesse, solicitaram brinquedos e brincadeiras e foram curiosas. Os exemplos a seguir descrevem tais situações relatadas e observadas:

\section{Participante A}

Bom + se ele esta dentro de um contexto que ele conhece + ele lembra dos brinquedos ou brincadeiras + então ele pede + ou quando ele ouve uma música que fala de bola + considero essas atitudes como iniciativa. Ele pede os brinquedos quando estão com os amigos e ele quer ++ assim como ele fez hoje com o caminhão (...)

Curioso ? ++ acho que sim ++ é sim + quando eu ou a auxiliar estamos fazendo alguma coisa ou estamos mexendo em algo ele chama + pede para ver + acho que em relação aos brinquedos ele é sim.

(...) quando a agente brinca por exemplo de passa a bola ele passa para os amigos + acho que é uma regra né + da atividade ((pesquisadora pergunta se a criança segue regras)) + mesmo que as vezes ele quer o brinquedo para ele eu explico e ele passa + a mesma coisa com a perua + ele sempre quer ser o primeiro + mas não da porque tem que ser na ordem em que eles SAEM da perua + então conversamos com ele e ele entende + as vezes reclama mas explicamos $(. .$.

\section{Participante B}

(...) sim ele brinca com as crianças e elas o ajudam na brincadeira + o tempo todo ++ eles não deixam ele sozinho de forma alguma + mesmo quando eles estão no parque envolvidos com outras brincadeiras + elas sempre dão uma passadinha ali né + tipo + elas vem sentam perto para brincar com ele + jamais deixam ele sozinho.

A professora do participante A descreveu que o aluno participou das atividades em sala, foi curiosa em relação aos brinquedos, e quando algo chama a sua atenção no contexto escolar quer saber o que o é ou quem está no local. Ainda em relação ao mesmo participante, 
a professora relatou que o mesmo é capaz de compreender regras e seguí-las durante as atividades e também de expressar a sua opinião em relação ao contexto em que participava.

Em relação ao participante $\mathrm{B}$ a professora relatou que o aluno participou das atividades planejadas junto às outras crianças, e quando ele apresentava dificuldade às próprias crianças da sala o ajudavam. Em relação ao parque (anteriormente a professora já havia relatado a dificuldade do participante B em participar destas atividades), ela considera que neste ambiente a criança consegue participar de algum tipo de brincadeira com as crianças mesmo que ela não consiga utilizar os brinquedos do local.

Os relatos das professoras dos participantes deste estudo descreveram o interesse e a intenção da criança em participar das atividades desenvolvidas nos diferentes ambientes da escola. O professor deve planejar atividades onde os recursos e as estratégias utilizadas possam ampliar as possibilidades de participação do aluno, atendendo à diversidade das crianças, e assim desenvolver diferentes habilidades, interesses e maneiras de aprender no desenvolvimento de cada capacidade (BRASIL, 1998; GONZÁLEZ, 2002; SORO-CAMATS, 2003; PELOSI, 2009).

Durante o procedimento de observação realizado pela pesquisadora foi possível identificar que ambos os participantes demonstraram interesse pelas tarefas em todas as atividades propostas pelas professoras, mas em decorrência de suas características e falta de recursos, os dois participantes quase sempre se mantinham como espectadores da atividade realizada, como pode ser visualizado a seguir:

\section{Participante A}

Atividade no tanque de areia

(...) o participante A estava muito feliz e sorridente, tentava manipular a pá de areia demonstrando interesse pelo objeto, mas não conseguia desempenhar a atividade com autonomia, necessitando da ajuda da estagiaria (...)

Neste momento ele disse por duas vezes que iria fazer bolo de chocolate, pedia para auxiliá-la pegar mais areia e chamava algumas crianças que estavam brincando no local naquele momento (...)

(...) a pá de pegar a areia estava com a auxiliar junto com outra criança, neste momento o participante A ficava ansioso para chegar a sua vez dizendo: agora sou eu, é minha vez (...).

(...) durante toda a atividade se apresentou interessado, interagindo de forma tímida com as crianças do Infantil II, preferindo apenas observar as crianças brincando. 


\section{Participante B}

Atividade em sala de aula

Enquanto as demais crianças da sala abrem o seu caderno, após orientação da professora o participante $B$ permanece esperando, sem nenhum recurso sobre a sua carteira. Em seguida o aluno estende o braço esquerdo para frente e levanta a cabeça, neste momento a professora coloca sobre a sua carteira um caderno e sai em seguida. Neste momento o Participante B direciona o olhar para as outras crianças da sala, que se encontram do seu lado esquerdo e que já estão abrindo os cadernos, realiza abdução do ombro esquerda e toca o rosto da criança que esta na carteira ao seu lado, em seguida leva a mão ate a mão da criança que esta realizando movimento para abrir seu caderno. Neste momento a criança ao lado ergue seu caderno, fazendo com que o Participante $B$ retire sua mão..

Através destes exemplos é possível perceber que apesar das dificuldades motora, perceptivas e comunicativas os alunos apresentaram o desejo de participar da atividade, para isso criam situações lúdicas, solicitam ajuda da auxiliar e das demais crianças que estavam no local naquele momento. É possível identificar que os recursos utilizados nas atividades propostas não permitiam a participação da criança com autonomia, e apesar do desejo de utilizar os recursos oferecidos necessita da ajuda constante de algum interlocutor mediador (BLANCHE, 2000, 2002; FERLAND, 2006; REIS; REZENDE, 2007; ROCHA et al., 2008).

Neste contexto Blanche (2000), destacou a necessidade do interlocutor mediador criar estratégias a fim de viabilizar a participação da criança com paralisia cerebral durante as atividades, esse procedimento permite que a criança desempenhe ações significativas e previne que o interlocutor mediador realize as tarefas de uma atividade pela criança.

Em relação ao Participante A foi possível identificar que o aluno se interessava pelas atividades com música, participando da atividade proposta pela professora.

\section{Participante A}

(...) neste momento ficou muito alegre, cantou junto a professora os trechos que ela solicitava sua participação e ficou bem agitado se mexendo na cadeira durante todo tempo (...)

.Ao decorrer da música cantava alguns trechos (...)

(...) ele se mostrou interessado na música, porém não canta, apenas repetia algumas vezes o final das frases.

(...) durante a musica a professora pedia a participação das crianças, o participante A durante toda a atividade solicitava a professora a sua vez. Quando chegou a sua vez demonstrou muita alegria e interagiu bem com a professora, cantando a musica pedida. 
Novamente foi possível notar o desejo do aluno em participar da atividade proposta pela professora. Judge, Floyd e Jeffs (2008), afirmaram que é necessário oferecer as crianças com deficiência física acesso as experiências significativas no processo de desenvolvimento e assim participar das atividades escolares com eficiência. A professora pode utilizar as atividades que as crianças apresentam maior interesse e participação para ampliar as oportunidades de aprendizagem significativa, para isso pode oferecer novos recursos que contemplem os objetivos pedagógicos do seu planejamento (ROCHA; DELIBERATO, 2009a, 2009b, SAMESHIMA; DELIBERATO, 2009).

Durante o período de observação do participante B foi possível identificar a dificuldade constante em utilizar os recursos para realizar as tarefas propostas pela professora o que dificulta a sua participação na atividade. O exemplo seguinte demonstra a dificuldade de manipular os objetos mesmo por um curto período de tempo:

\section{Participante B}

(...) a professora neste momento se aproxima da cadeira e tira o lápis e a borracha do estojo do A2, ele pega o lápis com a mão esquerda e realiza em seguida movimento de abdução de ombro, deixando o lápis cair no chão.

Os Participantes A e B apresentaram significativos comprometimentos motores, dificuldades em manter o controle postural adequado e de realizar o manuseio com os membros superiores. O recurso inadequado, além de não proporcionar experiências de aprendizagem significativas, faz com que a criança seja totalmente dependente de alguém. Os professores e profissionais que atuam na escola devem ter conhecimento de seu papel enquanto mediadores das atividades. Os procedimentos para realização de uma tarefa podem ser modificados para ampliar as habilidades do aluno nas atividades (MANZINI, SANTOS, 2002; MANZINI; DELIBERATO, 2004, 2007).

A criança com deficiência encontra dificuldades na interação com o meio, porém essas diferenças não deverão ser entendidas como um obstáculo perante o processo de aprendizagem. O uso de estratégias para adequar o meio será determinante ampliar a descoberta de habilidades e de possibilidades da criança no contexto escolar (ROSELL, 2003; JUDGE; FLOYD; JEFFS, 2008).

Durante a observação foi possível notar que em vários momentos os alunos necessitaram aguardar a presença da professora ou de outros profissionais da escola para ajudá-los nas atividades. Na classe especial a professora necessitou, durante as atividades, 
trabalhar individualmente com cada criança, utilizando estratégias especificas para cada aluno a fim de contemplar os objetivos propostos em seu planejamento. Mesmo durante o tempo que a professora esteja com uma criança especifica é importante que as outras estejam envolvidas na atividade. A professora do participante A relatou durante a entrevista que o aluno mantém a atenção na atividade enquanto ela está com outra criança e solicitava que fosse a sua vez:

\section{Participante A}

(...) + sempre apresentamos a atividade para todos e quando é a vez dos amigos e ele esta interessada pede para ser a sua vez.

A professora do participante B também necessitou de estratégias que atendam as necessidades individuais de cada criança da sala, porém, apesar de ter uma sala mais numerosa as crianças têm maior independência durante as atividades. Para a criança com deficiência esse ambiente pode ser importante, pois o meio pode favorecer mais experiências principalmente no que se refere a trocas com diferentes interlocutores e mediadores (FARIA, 2000, MELLO, 2004, 2007).

É possível notar que durante as atividades propostas o participante B sempre procura referências não só da professora mais também dos amigos da sala.

\section{Participante B}

Enquanto a professora conta a historia na frente de A2, ele direciona o olhar para trás em direção a arquibancada onde estão sentadas as crianças, em seguida desloca o andador para trás se aproximando dos amigos e da estagiária.

Essa troca com diferentes interlocutores é importante, porém é necessário que a professora se mantenha atenta para que a criança realmente participe das atividades. Quando a professora utilizou a estratégia de colocar alguma criança junto ao Participante $\mathrm{B}$, ele direcionou a atenção para a atividade que a mesma estava realizando, porém não participou ativamente das tarefas da atividade proposta.

Participante B

Criança: Quer fazer um coração? Empresta a sua canetinha?

Sem que o Participante B respondesse a criança pegou o seu estojo, abriu e tirou uma canetinha. Durante toda a ação o Participante B direciona o olhar para ela. Neste momento ela destampa a canetinha e desenha um coração na 
mão esquerda do Participante $\mathrm{B}$, que esta posicionada sobre o caderno dela. Em seguida diz:

Criança : Olha aí, ta bonito?

O Participante $\mathrm{B}$ estende a mão e olha em direção ao desenho que a amiga fez. Ela ao lado sorri e diz:

Criança: Quer outro, quer?

Sem que ele responda, ela pega outra canetinha no estojo dele e desenha outro coração em sua mão esquerda. Ele realiza um movimento involuntário mexendo a mão e ela diz:

Criança: AH... você fez eu errar, fez eu errar tudo, olha ai se ficou bom?

O Participante 2 leva a mão em direção do seu rosto e direciona o olhar para o desenho que a amiga fez e sorri, em seguida leva a mão ate a amiga de novo

A criança então segura a sua mão e da um beijo.

O professor deve fornecer recursos e utilizar de estratégias para ampliar as habilidades motoras, perceptivas e comunicativas da criança com paralisia cerebral para que ela possa interagir com o meio e com os diferentes interlocutores do contexto escolar (SOROCAMATS, 2003; BASIL, 2003; BERSH, 2008; PELOSI, 2003, 2008, 2009).

É comum que o aluno com paralisia cerebral apresente dificuldade em realizar tarefas escolares rotineiras e por isso dependam de ajuda e cuidados de outra pessoa. Quando isso ocorre, ele fica em desvantagem, pois não tem oportunidades de se desafiar e criar como seus colegas. É muito frequente encontrarmos alunos que assistem seus colegas e não podem ser atores do seu processo de descoberta e aquisição de conhecimento (BRASIL, 2007).

\subsubsection{Desempenho do aluno}

É possível notar que a criança com deficiência física muitas vezes apresenta interesse em realizar as atividades propostas, porém devido as suas incapacidades motoras, comunicativas e perceptivas, não consegue fazê-las de forma independente. Através dos procedimentos da Etapa 1 foi possível identificar alguns aspectos do desempenho motor, comunicativo e perceptivo.

Em relação ao desempenho motor no momento da entrevista as professoras relataram algumas situações que demonstraram a dificuldade motora da criança:

\section{Participante A}

O PA tem muita dificuldade motora + ele melhorou muito "principalmente com a nova medicação que esta tomando + mas ainda tem muita dificuldade 
em manipular os brinquedos ++ sempre precisa de ajuda porque os bracinhos estão sempre em flexão e mesmo quando ele consegue estender não vai muito ai precisa de alguém ajudar + abrir a mãozinha dele colocar no brinquedo e ajudá-lo a sentir (...)

Ele tenta ++ mas sozinho não consegue + ele tem a intenção de manipular + procura + pede + mas sozinho não manipula + precisa de alguém para ajudar devido ao motor. ((pesquisadora pergunta se ele explora brinquedos com independência))

(...) necessita ser ajudado por alguém sempre + pelo comprometimento motor que ele tem + não consegue pegar "manipular o brinquedo + necessita sempre de alguém ajudando (...)

Participante B

(...)ele já tem mais dificuldade com a bola né + porque o andador impede ele de chutar + mas ele consegue chutar + a bola eu já expliquei $+o$ bambolê ele AMA o bambolê + mas o bambolê é uma brincadeira assim mais + mais difícil dele estar participando + mais e a movimentação assim com os braços né + que a gente vai estimulando tá.

(( Pesquisadora pergunta sobre como a criança explora os brinquedos)) era com bastante dificuldade ++ porque o problema justamente dele são os braços + a gente tinha que estar sempre segurando para ele + colocando em algum lugar que tivesse sempre o acesso melhor para movimentação dos braços né...é a parte motora dele + que é onde ele tem a maior dificuldade

Nestes exemplos as professoras enfatizaram a dificuldade das crianças no manuseio do recurso e a necessidade de receber ajuda durante as atividades. O desempenho motor foi amplamente observado pelo procedimento das filmagens, como descreve os exemplos a seguir:

\section{Participante A}

(...)durante a atividade apresentou muita dificuldade em manusear a bola, não conseguiu jogá-la para professora, após algum tempo tentando jogar ela escapou de suas mãos involuntariamente, pois ele entrou em padrão flexor de membro superior. A professora novamente posicionou a bola, porém desta vez a pequena, e novamente a criança entrou em padrão flexor.

(...) a professora ajudou o participante A a manusear a bola, quebrando padrão de membro superior e manipulando tronco, braços, antebraços $e$ mão para que conseguisse pegar a bola e solta-la (...)

(...)após realizar a atividade, assim que a mão era solta pela professora a criança imediatamente entrou em padrão flexor, reforçando ainda mais o padrão patológico (...)

Participante B 
Enquanto a estagiaria auxilia a criança ao lado de do Participante B, ele bate a mão no caderno que esta em sua mesa de apoio e o derruba, neste instante a estagiaria pega o caderno o coloca na carteira da sala e abre novamente na pagina onde será proposta a atividade, em seguida se desloca deixando o caderno sobre a carteira da sala, fora do alcance do aluno. A criança permanece quieta, direcionando o olhar para a professora que se encontra na frente da sala de aula durante aproximadamente 20 segundos. Em seguida inicia uma série de movimentos involuntários com membros superiores, inferiores e cabeça, em seguida realiza a extensão da cabeça e por reação reflexa estende o restante do corpo, deslocando o andador para trás, e em seguida para frente empurrando a carteira da sala de aula que esta nesta direção. Neste momento a estagiaria que esta atrás da criança se aproxima coloca o andador para trás e traz novamente a carteira para sua posição inicial. Em seguida a estagiaria pega o estojo do A2 na mão e retira um lápis, A2 realiza a abdução do ombro e leva a mão próxima a estagiaria.

Em seguida orientou as crianças em dupla a separar as letras feitas em quadrados de papel sulfite com aproximadamente $3 \mathrm{~cm}$ correspondente ao nome de cada animal e colar na folha onde estavam as quatro figuras, colando cada nome em frente à figura correspondente.

O participante B não conseguiu levar as mãos até as letras, pois ao tentar realizar este movimento iniciava uma série de movimentos involuntários derrubando e amassando as letras e o papel que estava em cima da carteira.

A dificuldade motora interfere diretamente na capacidade da criança de explorar o ambiente e consequentemente pode trazer prejuízos em seu desenvolvimento, pois a criança com paralisia cerebral pode deixar de vivenciar sensações diferenciadas e, com isso seu processo perceptual não seria estimulado, acarretando atrasos ou retardos em diferentes habilidades, como no caso da linguagem (DELIBERATO, 2000; 2001; ARAUJO; MANZINI, 2005; ANSON, 2007; BRACCIALLI, 2007).

Reis e Rezende (2007), relataram que por meio da tecnologia assistiva seria possível adaptar utensílios e ou ambientes para compensar as deficiências das crianças e, também pode ser recomendada quando se espera resultados funcionais ou quando a adaptação é mais eficiente em termos de gasto de energia, tempo e recursos financeiros.

$\mathrm{O}$ participante $\mathrm{A}$ apresentou padrão flexor de membros superiores devido à paralisia cerebral do tipo espástica. Este padrão fez com que a criança tivesse dificuldade para realizar a extensão das mãos, punhos e dedos e consequentemente dificuldades em manipular diferentes materiais. $\mathrm{O}$ aluno também apresentou influência de atividade tônica reflexa, ou seja, alguns estímulos do ambiente provocaram reações corporais reflexas que prejudicaram o seu desempenho durante as atividades. 
Finnie (2000), apontou que as principais dificuldades dos professores de crianças com sequelas de paralisia cerebral estão relacionadas ao desenvolvimento de atividades com tarefas que necessitam da preensão, do alcance, e da manipulação de recursos, ou seja, os professores têm dificuldade em planejar estratégias para facilitar a execução de atividades em que as crianças com paralisia cerebral necessitam utilizar os membros superiores. As habilidades para executar as atividades pontuadas por Finnie (2000), têm sido instrumentos de pesquisa dos pesquisadores que buscam sistematizar padrões de motores para alunos com paralisia cerebral que facilitem a participação nas tarefas escolares e, assim facilitarem a aquisição de leitura e escrita (RADELL, 1996; BRACCIALLI; MANZINI e AIRES, 2003; BRACCIALLI; MANZINI; VILARTA， 2005; AUDI, 2006; REGANHAN, 2006; BEUKELMAN; MIRENDA 2007; OLIVEIRA, 2007; BRACCIALLI et al., 2008).

Referente ao desempenho motor do Participante B foi possível notar que ele apresentou alterações no tônus, pois apresenta paralisia cerebral do tipo discinética, neste caso, foi possível observar movimentos involuntários do tipo distônico (movimentos amplos e fixos, menos intensos).

Além da alteração do tônus o participante B apresenta também, através do Reflexo Tônico Cervical Assimétrico (RTCA) o Reflexo Tônico Labiríntico (RTL). Na atividade apresentada anteriormente foi possível identificar que o participante B deslocou o andador através de reações corporais reflexas.

$\mathrm{Na}$ situação exemplificada seria adequado que a atividade proposta estivesse na altura dos olhos da criança, assim como a professora, evitando que acontecesse uma hipertonia extensora (aumento do tônus que provoca movimentos de extensão), quando a criança eleva a cabeça. Ainda no caso do deslocamento do andador, percebeu-se que o Participante B já desenvolveu habilidades funcionais a partir da utilização de tônus postural anormal e atividade reflexa, ou seja, o aluno apresenta funcionalidade na atividade através de movimentos desencadeados pela persistência dos reflexos primitivos.

A identificação da funcionalidade das ações motoras do aluno com paralisia cerebral pode não ser identificada por professores ou mesmo por profissionais da saúde. Deliberato (2007, 2008) e Nunes (2003) alertaram o uso de padrões motores dos alunos com paralisia cerebral na tentativa de estabelecer interação e diálogo com diferentes interlocutores quando utilizam recursos de comunicação alternativa.

Durante as atividades externas como na quadra e no campo foi possível observar o uso da funcionalidade motora do participante $\mathrm{B}$, porém é importante ressaltar a importância do uso de recursos adaptados no momento em que o aluno com paralisia cerebral está em 
atividades que necessitam de uma atenção direcionada, como no caso do uso das mãos para a realização de tarefas. Nesta situação é indispensável uma melhor adequação postural a fim de favorecer o uso das mãos e facilitar a habilidade de coordenação viso motora para a manipulação e manuseio dos materiais (MANZINI, 1999; PELOSI, 2003, 2008; BERSH, 2008; BRACCIALLI et al., 2008).

Durante a entrevista a professora demonstrou preferência em manter o participante B no andador durante as atividades externas. Tal preferência poderia estar associada ao fato de acreditar que ao utilizar o andador, o aluno poderia estar treinando sua marcha, como pode ser observado por meio do exemplo a seguir:

\footnotetext{
Participante B

No andador ++ quando é no parque que eu tiro ele do andador, ele fica na + comigo no +++ sem o andador + sem sapato + andando pelo parque sem sapato + para forçar ele a andar né + para esforço das perninhas + mas mais assim ++ as outras brincadeiras que eu dou tanto na quadra como no campo eu prefiro que ele fique no andador.
}

O exemplo demonstrou que a falta de capacitação do professor pode favorecer o uso inadequado de recursos. $\mathrm{O}$ andador do participante $\mathrm{B}$ não é um recurso adequado as suas especificidades motoras o que poderia acarretar prejuízos no processo de reabilitação do aluno do ponto de vista motor. A seleção e adequação de mobiliários devem ser feitas por profissionais capacitados, como no caso da terapia ocupacional e fisioterapia. Araujo, Deliberato e Braccialli (2009), discutiram a necessidade do trabalho em equipe e de formação específica na área de tecnologias assistivas para os diferentes profissionais.

O vínculo entre os profissionais da saúde e educação poderia facilitar a implementação de programas para alunos com paralisia cerebral e, assim, viabilizar a manutenção do aluno com deficiência na educação infantil e fundamental (ROTHSCHILD; SWAINE, 2001; DELIBERATO, 2005, 2009; BEUKELMAN; MIRENDA, 2007; PELOSI, 2009; BERSH, 2009).

A literatura que trata de mobiliários para alunos com paralisia cerebral enfatizou a necessidade do adequado posicionamento para diferentes atividades não só para ampliar a funcionalidade das ações dos alunos, mas também para evitar prejuízos nas aquisições motoras e prevenir deformidades (RADELL, 1996; BRACCIALLI; MANZINI e AIRES, 2003; BRACCIALLI; MANZINI e VILARTA, 2005; BEUKELMAN; MIRENDA, 2007; OLIVEIRA, 2007; BERSH, 2006, 2008, BRACCIALLI et al., 2008, BRACCIALLI, 2009). 
Os pesquisadores também discutiram que além dos recursos adequados estarem disponíveis para os professores utilizarem, há necessidade de adequações no manuseio das crianças com paralisia cerebral, inclusive para colocá-los nas cadeiras adaptadas (BRACCIALLI; MANZINI e AIRES, 2003; BRACCIALLI; MANZINI e VILARTA, 2005; BEUKELMAN; MIRENDA, 2007; BERSH, 2006, 2008; OLIVEIRA; 2007).

A preocupação com o adequado manuseio do aluno com paralisia cerebral foi observado durante a entrevista com a professora do participante A. A professora relatou ter dificuldades em posicionar a criança mesmo que a classe especial para deficientes físicos ofereça maior quantidade de recursos para a adequação postural dos alunos. Durante as observações foi possível identificar situações em que a professora necessitava adequar a postura da criança constantemente, situação que pode prejudicar a atenção da criança frente à atividade proposta pela criança. A seguir serão apresentados exemplos da entrevista e da observação do participante A que indicam a dificuldade em relação ao posicionamento.

\section{Participante A}

(...) posição é difícil ++ fica muito difícil posicionar ele....ele não se locomove com independência + necessita de auxilio (a pesquisadora perguntou quais as maiores dificuldades em relação aos aspectos motores)

(...) após alguns momentos escorregava e saia do posicionamento, sendo colocado novamente na posição adequada pela professora ( ...)

O participante A se encontrava sem apoio de pescoço, com apoio de tronco, quadril fletido, pernas abduzidas e joelhos fletidos, não conseguia sustentar a cabeça por muito tempo, sendo constantemente lembrado de arrumar a cabeça porém só conseguiu com a ajuda total da professora (...)

Segundo as orientações de documentos nacionais em relação ao posicionamento para a manutenção da qualidade de tônus postural e a inibição de reações corporais reflexas são fundamentais, principalmente com os alunos menores que estão em processo de desenvolvimento, aprendendo estratégias de movimento, que posteriormente farão parte de seu repertório motor (BRASIL, 2007).

Cabe ressaltar que grande parte dos alunos com paralisia cerebral na educação infantil não estão com mobiliários adequados para desenvolver suas tarefas na rotina escolar (OKOLO; BOUCK, 2007).

Quando as crianças têm a presença dos equipamentos, o professor do ensino regular ou mesmo do especial podem não conseguir utilizá-los pela falta de conhecimento a respeito do recurso, ou ainda em função das características de cada aluno com paralisia cerebral, como foi 
possível observar nos exemplos descritos. É fundamental que os recursos atendam as necessidades especificas do aluno e a formação do professor, para que possam favorecer a aprendizagem significativa dos alunos, seu desempenho e, desta forma modificar a sua participação no contexto escolar.

As habilidades comunicativas dos alunos com paralisia cerebral no contexto escolar têm sido amplamente discutidas pela literatura nacional e internacional (NUNES, 2003; LIMONGI, 2000, DELIBERATO; MANZINI, 2001; VON TEZTCHNER et al, 2005; VON TEZTCHNER, 2009; SOTO; VON TEZTCHNER, 2003; DELIBERATO, 2005, 2007, 2008, 2009; SAMESHIMA, 2006; ALVES; 2006). Quanto aos aspectos comunicativos pode-se observar que os participantes A e B apresentaram diferenças significativas entre eles. A seguir serão apresentados exemplos das habilidades comunicativas apresentadas durante a Tarefa 1

Participante A

O participante A estava brincando no tanque de areia e próximo a ele havia outras crianças, quando ele perguntou:

PB: quem ta ai? ...

Após o lanche da manhã o participante A começou a perguntar :

PB: o tio $\mathrm{N}$ vai buscar (refere-se ao motorista).

A professora perguntou:

Professora: Participante A posso sujar seu pé?

E ele respondeu

PB: pode...

(...) neste momento o aluno quis pegar a bola que estava com a professora e disse:

PB: Deixa eu pegar

Participante B

Para realizar a atividade foi auxiliado totalmente pela professora não mostrando uma forma definida de mostrar quais letras eram corretas para completar as palavras, e muitas vezes a professora questionava qual a letra correta e ela mesma respondia pela criança.

Estagiaria: Tira quatro palitinhos, tira quatro palitinhos

A criança inicia movimentos involuntários e após alguns instantes direciona o olhar para as mãos da estagiária e levava a mão direita para em sua direção retirando três palitos de uma só vez da mão da estagiaria. A estagiária diz:

Estagiaria: Três, tira mais um

A criança inicia uma série de movimentos involuntários e em seguida tenta pegar com a mão direita o palito da mão da estagiaria, e esta diz:

Estagiaria: Mais um palito, não, um só... um só 
A criança com a mão direita e corpo virado para a esquerda pega um palito e olha para a estagiária. A estagiária pega o palito da mão da criança, mostra os palitos que ficaram na mão dela e diz:

Estagiaria: Quantos ficaram aqui?

A criança emite som que não é possível entender, e a estagiaria diz:

Estagiária: AH?

Criança novamente emite som que não é possível entender e a estagiaria diz:

Estagiária: Quantos? Três (a própria estagiária responde, fazendo gesto afirmativo com a cabeça).

Em seguida a estagiária pega o lápis e escreve o resultado no caderno da criança que esta sobre a carteira, sem mostrar para aluno o que esta fazendo.

Por meio dos exemplos foi possível observar que o participante A conseguiu expressar seus sentimentos por meio da fala, expressões faciais, sorrisos, choro e apesar de ter um comprometimento motor significativo, conseguiu utilizar os membros superiores com função comunicativa.

Durante a observação, conforme os exemplos citados anteriormente, pode-se vivenciar situações que permitiram a identificação do desempenho comunicativo do participante A. Por meio dos exemplos foi possível perceber que o participante A expressa intenções através da fala nas situações dialógicas, mas a estrutura dos enunciados verbais não está compatível para sua idade. Cabe ressaltar que o participante A apresenta além das alterações motoras dificuldades no processamento visual, ou seja, embora tenha acuidade visual nos padrões de normalidade, o aluno apresenta lesões no processamento da informação visual, acarretando prejuízo não só na realização de suas tarefas escolares, mas também no recebimento das informações ambientais necessárias para a construção do conhecimento e da linguagem (FORGUS, 1971; HÉCAEN, 1978; DELIBERATO, 2000).

A literatura discutiu que grande parte dos alunos com paralisia cerebral pode apresentar alterações perceptivas que poderiam interferir no processo de aprendizagem e desenvolvimento global (TABITH, 1980; LIMONGI, 2000, 2003; LAMONICA, 2004).

Quanto ao desempenho comunicativo do participante B foi possível observar que aluno se expressou com maior facilidade através do olhar, em vários momentos da observação foi visto que mesmo a criança emitindo sons, no entanto, a professora e a estagiária apresentaram dificuldade em compreender a fala do aluno. A dificuldade ficou evidente durante as duas atividades indicadas anteriormente, a primeira a professora não conseguia identificar quais as letras a criança estava indicando para formar a palavra, e na segunda atividade a estagiária também não compreendeu o aluno quando foi necessário dizer um número. 
É importante ressaltar que mesmo que o participante B não conseguiu se expressar ele compreendeu as orientações que foram dadas, isto é possível ser identificado na atividade de matemática, pois apesar de sua dificuldade motora ele realizou as ações que a estagiária indicou.

Em outra atividade do participante B a professora realizou perguntas e ele faz novamente uso de olhar e gestos para efetivar sua comunicação:

\section{Participante B}

O Participante B direciona novamente o olhar para a esquerda onde estão sentados as crianças da sala, neste momento a professora diz.

M2: Com a D., você quer sentar com a D.? É?

$O$ participante B balança a cabeça para cima e para baixo como se fizesse um sinal afirmativo.

M2: Você quer sentar com a D.?

Após a professora perguntar novamente o Participante B, apresenta uma série de movimentos involuntários. Neste momento a professora diz para a criança que esta do seu lado

M2: Troca de lugar com a D. fazendo favor, senta lá e deixa a D. sentar aqui perto.

Em seguida a professora pergunta para o Participante B:

M2: Você quer tirar essa blusa, você esta com calor?

Antes de o aluno responder a professora se afastou foi ate a frente da carteira e a arrumou, em seguida a $D$. sentou na cadeira ao lado do Participante $B$...

(...) em seguida o participante $B$ direcionou o olhar para a criança que veio sentar ao seu lado. $O$ Participante $B$ virou o rosto para a criança ao lado e emitiu um som. Neste momento a D. disse:

D.: Porco. O Participante B arrotou tia, ele arrotou.

Nos momentos em que a professora questionou o Participante B e ele não apresentou uma fala compreensível, gerou grande tensão ao aluno. Neste contexto é necessário destacar que a dificuldade em realizar uma atividade que não esta adequada as suas necessidades pode provocar alteração de tônus, estimulando os movimentos involuntários. Para amenizar esta situação é possível utilizar recursos da comunicação alternativa e suplementar (prancha com figuras, letras ou números, atividades pedagógicas adaptadas, entre outros), para o aluno se expressar e estabelecer uma comunicação mais eficiente.

Segundo relatos das professoras na entrevista, elas indicaram ser possível compreender a criança através destes diferentes meios de comunicação. 
(...)quando esta interessado ele sorri + pede para pegar(...) quando não quer algo também mostra insatisfação + chora + e agora ele esta "pedindo (...)

(...)ele pede o que QUER + quando quer bola pede a bola quando quer o balde pede quando não quer também fala ou chora + reclama (...)

Participante B

Bom a gente tem que tentá-lo compreender ao MAXIMO ++ porque quando ele fica mais nervoso ai que ele não consegue mesmo falar o que ele ++ ta querendo né + então mais assim ++ da fala ele melhorou bastante mesmo + a gente pode compreendê-lo através da fala.

(...) + da questão da gente estar tentando entende-lo sempre que possível né ++ por que as vezes não é possível + para não deixar ele nervoso+ porque as vezes ele ate chora né + é o stress que ele fica né.

Nas observações realizadas do participante B foi possível perceber que embora o aluno tenha alterações na produção da fala, a professora conseguia entendê-lo, caso isto não ocorresse, o aluno desistia da situação e ficava irritado. Outra situação observada foi a professora responder pelo aluno, principalmente quando o mesmo não era compreendido, prejudicando desta forma a autonomia e a participação do mesmo enquanto sujeito participativo do discurso

Segundo Von Teztchner e Martisen (2000); Deliberato (2005; 2009); Von Teztchner (2009) a introdução de um sistema de comunicação suplementar e alternativa deve acontecer não somente para contemplar as questões comunicativas, mas os recursos de comunicação alternativa poderiam ser facilitadores no processo da aprendizagem significativa além de propiciar caminhos para a aquisição da leitura e escrita.

Segundo Deliberato (2005, 2007), o sistema de comunicação vai ser mais eficiente no momento em que os profissionais perceberem que o uso adequado de recursos adaptados para a comunicação alternativa poderia facilitar a participação do aluno com paralisia cerebral nas situações dialógicas, e poderia também favorecer a ampliação da participação dos diferentes interlocutores com os alunos com paralisia cerebral. Outro aspecto pontuado por meio da literatura é a importância dos professores e demais profissionais observarem as diferentes habilidades comunicativas já utilizadas pelos alunos, como no caso do uso de gestos, linguagem de sinais, vocalizações, expressões faciais (VON TEZTCHNER; MARTINSEN, 2000; ALVES, 2006).

As informações a respeito de habilidades comunicativas não orais poderiam ser obtidas por meio do contato com a família do aluno e assim seria possível a sistematização de significados atribuídos aos diferentes meios utilizados para a comunicação. 
Em relação aos aspectos perceptivos do participante $\mathrm{B}$ foi possível observar desempenho favorável nas atividades que envolviam habilidades sensoriais auditivas e visuais. Ainda em relação a esse participante, não foi observado por meio dos relatos da professora desempenho que pudesse ser entendido como prejuízo cognitivo.

Em relação aos aspectos perceptivos do participante A como já citado anteriormente, o aluno apresentou acuidade auditiva nos padrões de normalidade e embora tivesse acuidade visual, sua habilidade de percepção nesta função estava comprometida em decorrência da lesão neurológica. Nesta perspectiva a professora relatou durante a entrevista as seguintes informações:

\section{Participante A}

(...) não conseguimos saber se ele entende o que esta passando nas imagens da TV ((professora relata sobre as atividades na sala de video)) pela visão dele mas ele " canta e mostra bastante interesse nas musicas + mesmo que ele não compreenda as imagens.

(...) quando ele houve a música sobre a bola ele na hora pede a bola e quer brincar ++ é engraçado porque mesmo com a dificuldade na visão ele brinca com a bola + passa para os amiguinhos.

Diante destas questões foi identificado que a criança em alguns momentos necessitou de auxílio de pistas para localizar o objeto. Estas pistas foram oferecidas através de objetos com som ou pistas do mediador da atividade sobre a sua localização (na sua frente, atrás, do lado). Desta forma foi possível observar trechos das observações que demonstraram este fato:

\section{Participante A}

Durante a atividade com a bola a professora ofereceu pistas sobre a localização da mesma para que ele conseguisse encontrar a bola e se concentrar na atividade

A professora colocou a bola ao lado direito da criança na altura da cabeça e disse:

A2: Participante A, onde esta a bola?

Neste momento a professora balançou a bola e a mesma emitiu som de guizos, o aluno direcionou o olhar para a bola e disse:

P2: deixa eu pegar!

A professora então respondeu, trás o bracinho para pegar aqui na minha direção.

Outro aspecto relatado pela professora durante a entrevista diz respeito à memória auditiva da criança, segundo ela o participante A memorizava as atividades de sua preferência 
e assim que percebia algo que chamasse sua atenção referente ao contexto dessas atividades, ele solicitava a professora a sua participação nas tarefas. Segue a seguir o exemplo relatado pela professora durante a entrevista:

\section{Participante A}

(...) ele tem uma memória muito boa e guarda o contexto das atividades e quando vê o contexto pede o que é de interesse dele.

Por meio do exemplo acima é possível perceber a habilidade auditiva do aluno e a capacidade do professor observar esta habilidade. Soro-Camats (2003), advertiu a importância dos profissionais atuarem com crianças, jovens e adultos deficientes a partir de suas habilidades. A função auditiva do participante A demonstrou colaborar com sua participação nas tarefas propostas pela professora, sendo assim, ao se pensar nos recursos de tecnologia assistiva para este aluno, o professor pode e deve incluir elementos facilitadores para o uso do equipamento. Nesse caso, recursos com elementos auditivos poderiam ampliar a participação do aluno e facilitar o uso da função visual que estava comprometida.

É possível perceber que o participante A apresentou limitações em seu desempenho motor, comunicativo e visual, condições estas que poderiam impedir a sua participação nas atividades escolares com autonomia. É necessário pensar em recursos e estratégias que venham ampliar suas habilidades, favorecer o seu desempenho e consequentemente facilitar o seu processo de aprendizagem (JUDGE; LAHM, 1998, LANGONE; MALONE; KINSLEY, 1999; SORO-CAMATS; 2003; MISTRETT et al., 2005; DELIBERATO; 2007, 2009a).

Durante a fala anterior da professora é importante destacar que apesar de conhecer o comprometimento motor da criança, ela está atenta às suas habilidades, como no caso da habilidade auditiva. É extremamente importante que o profissional que trabalhe com o aluno com paralisia cerebral perceba as suas habilidades, e as utilize a fim de modificar continuamente a sua funcionalidade no ambiente, transformando o contexto no qual ele está inserido.

\subsubsection{Conduta do aluno}


Autores dedicados no desenvolvimento de crianças com paralisia cerebral discutiram a respeito de possibilidades de observar condutas comportamentais em função das diferentes alterações neurológicas e ambientais (TABITH, 1980; LIMONGI, 2000, 2003; LAMONICA, 2004; MANZINI, 1999).

As crianças com paralisia cerebral podem manifestar seus desejos, intenções, vontades por meio de diferentes comportamentos ou condutas. Estas condutas podem ou não ser adequadas para o ambiente de sua atividade.

Durante a entrevista as professoras relataram a sua percepção em relação à conduta das crianças no contexto escolar:

\section{Participante A}

(...) quando a gente faz brincadeiras com as outras crianças da escola + do Infantil, do maternal ele interage sim + se comunica pede brinque:dos as crianças também conversam com ele + mas com as crianças aqui da sala é mais difícil ele é o que mais se comunica as outras crianças não se comunicam tanto + então é difícil ++ nós temos que trabalhar o grupo mas de forma mais individualizada ++ " você vê né ++ as crianças não interagem muito entre elas + mas quando esta em atividades no parque no gramado ele interage com as crianças sim + pergunta responde + ele fica muito feliz.

Bom ++ vamos ao gramado, na sala de aula, vamos também ao parque brincar na areia com as outras crianças ++ mas para a interação...

...+ e neste momento ele interage com as outras crianças que estão no tanque de areia + principalmente do maternal e Infantil I.

(...) as brincadeiras com as crianças das outras salas quando conseguimos envolver as salas é interessante pela interação ++ mesmo que eles não consigam brincar na areia com o baldinho é interessante pela interação....

\section{Participante B}

Nossa ele é + é demais + ele você vê ele buscando né + eu to explicando as atividades ele quer + ele da a opinião dele + ele quer saber + ele pergunta sim + ele é curioso demais " graças a Deus ((risos da entrevistada)).

((Pesquisadora pergunta o que a criança faz quando quer alguma coisa na escola)) .... ele busca + ele pede o que ele quer + isso ele pede mesmo.

(...) ele não tem medo de nada ++ o bom do P2 é isso né ++ ele enfrenta TODOS os desafios.

Interage sim + algumas crianças + ele com as crianças sim + algumas crianças tem um certo ciúme porque as vezes a minha atenção é maior com ele né + então tem um certo ciúme + surge algum atrito mas nada assim + mas + mas com relação a ele com as crianças não + porque as crianças estão sempre prontas a atende-lo né + também já é delas né + já vem delas. 
(...) é ++ a única assim o parque mesmo eu não colocava ++ eu já tentei colocá-lo nos brinquedos + mas assi:m + eu via que ele não se sentia a vontade + então o parque para ele + assim é o parque + então assim + era ate bom para mim porque eu via que ele não se sentia a vontade + então eu abraçava o que " dava + o que ele se senti-se bem lá + era o lugar assim que mai:s ++ e também né para ele não deve ser fácil né + todas as crianças correndo brincando subindo descendo e ele não conseguir né + ainda mais ele que é uma criança que enfrenta todos os desafios + então para ele eu achava meio complicado o horário de parque.

Em relação à conduta do participante $\mathrm{A}$, a professora relatou durante a entrevista que o aluno apresentava dificuldades em interagir com as crianças de sua sala. No período de observação foi possível identificar que durante as atividades o aluno direcionava sua comunicação e expressões apenas para a professora e auxiliar. Esse fato pode ter acontecido, pois as crianças que frequentavam a sala do aluno apresentavam além de deficiências motoras graves, distúrbios severos de comunicação o que dificultava a interação comunicativa entre elas. Durante o procedimento de observação foi notado o esforço da professora do participante A em realizar atividades que agrupassem outras salas de aula da escola, no momento da coleta aconteceram quatro situações onde esse fato ocorreu, sendo duas delas em atividades no tanque de areia e duas atividades utilizando músicas.

Referente ao Participante B, no momento da entrevista a professora relatou que o aluno se envolve nas atividades sempre buscando e pedindo o que quer além de realizar perguntas quando quer saber de algum assunto. Em relação à interação do Participante B com as outras crianças a professora relatou que apesar de perceber o ciúme que as demais crianças da sala apresentam em relação a ela e o Participante B, acredita que a interação entre os alunos e o participante B é satisfatória. A professora também descreveu na entrevista que a criança não se sentia à vontade durante as atividades no parque, pois não conseguia realizar as tarefas motoras como as outras crianças da sala.

Durante a observação foi possível identificar condutas nos participantes que demonstravam sentimentos de felicidade, tristeza, desejos e desinteresse. A seguir é possível observar exemplos destas situações:

\section{Participante A}

(...) o Participante A é o penúltimo a entrar na perua, pois as crianças são colocadas conforme a ordem de desembarque, durante esse tempo de espera ele ameaçou chorar e pedia constantemente para ser a sua vez, dizendo "agora sou eu" 
(...) em seguida a professora veio mostrar a criança como ficou a sua mão na cartolina, neste momento ela disse para criança:

M2: Participante A olha a sua mão aqui no papel

Juntamente com a sua fala pegou na mão da criança e levou em direção a cartolina, tateando o papel.

$O$ aluno não direcionou o olhar para o desenho, conforme solicitado e não apresentou nenhuma reação de satisfação em relação a atividade

Em relação ao Participante A, ao pensar nas preferências da criança foi possível notar que o aluno conseguiu demonstrar seu interesse pela atividade solicitando sua participação no contexto. Durante as observações do aluno foi identificado esse comportamento no momento da chegada do transporte, no momento em que o aluno ao ver as outras crianças sendo colocadas na perua, pediu para que fosse colocado também.

Foram identificados também momentos em que a criança demonstrou falta de interesse pela atividade que estava sendo realizada, foi possível observar essa situação ao final de uma atividade de pintura em que a professora trouxe a cartolina com o desenho da mão do aluno. Essa conduta apresentada pela criança pode estar relacionada ao seu comprometimento visual, pois a falta de habilidade em visualizar o desenho pode fazer com que a atividade não seja significativa para o aluno.

Durante a observação foi possível notar que o Participante B tentou se aproximar dos demais alunos, mas o seu comprometimento motor não permitiu que ele tivesse uma relação satisfatória. Por meio do exemplo a seguir é possível perceber uma situação em que o Participante B interagiu com a amiga que estava sentada ao seu lado:

\section{Participante B}

D.: Me da essa figura?

O Participante B inicia uma série de movimentos involuntários e leva a mão próximo ao cabelo da D., o puxando para trás, ela então diz:

D.: Não puxa o meu rabo

O aluno então solta o cabelo da D.i, em seguida ela aponta para outra figura de sua mesa de apoio e diz:

D.: Pode pegar essa Participante B?

$O$ aluno mantém o braço nas costas de D. próximo ao cabelo, e não responde a pergunta, em seguida a amiga diz:

D.: Pode?

Ela começa a tirar com a mão, sem que A2 responda e diz:

D.: Espera ai que eu vou tirar.

Em outro momento da observação foi possível perceber que a criança que interagia com o participante B ainda não era capaz de perceber as suas dificuldades, pois após ações motoras do participante com a intenção de estabelecer contato, a criança ao seu lado 
apresentou comportamento hostil. Esta reação pode ser observada por meio do exemplo a seguir:

\section{Participante B}

O Participante B tentar tocar através das mãos no caderno da criança ao lado, neste instante a criança retira o caderno do alcance do aluno. $O$ Participante $B$ se desestabiliza em seu andador iniciando movimentos involuntários nos membros superiores, inferiores e cabeça.

Neste momento a criança ao lado pega o caderno do Participante B e diz:

Criança: Olha o seu aqui.

Em seguida a criança abre o caderno do Participante B, enquanto ele observa a ação do amigo direcionando o olhar para o caderno.

A criança vira a pagina do caderno e com o dedo aponta uma atividade e diz:

Criança: Oh!, Oh!

O Participante B eleva a cabeça e sorri, em seguida a criança continua virando as paginas do caderno e quando chega na pagina da atividade que a professora esta propondo para o dia a criança bate na pagina por três vezes e diz:

Criança: Aqui oh, aqui, você tem que fazer Participante B.

As escolhas das estratégias de intervenção muitas vezes estão relacionadas às habilidades da criança, sempre na tentativa de ampliar suas oportunidades em seu contexto, sua comunicação, seus parceiros, suas tarefas e sua interação (BLACKSTONE; BERG, 2003).

Perceber habilidades dos alunos com paralisia cerebral poderia direcionar as ações de confecção de recursos de tecnologia assistiva de forma a ampliar a participação dos alunos nas tarefas propostas e diminuir condutas inadequadas (WALTER, ALMEIDA, 2007).

É fundamental que a escola desenvolva estratégias para que as crianças e profissionais possam interagir e desenvolver atitudes para ampliar as oportunidades de todos, considerando as diversidades. Esse comportamento complementa a formação dos alunos com vistas à diversidade na escola e fora dela (BRASIL, 2007).

\subsection{Tarefas 2, 3, 4, 5: Prescrever e confeccionar o recurso de tecnologia assistiva}

Após a análise dos dados da Tarefa 1 foi possível entender a situação do aluno no contexto escolar, ou seja, quais os ambientes que frequentava, quem eram os interlocutores mediadores, quais os recursos e as estratégias faziam parte do planejamento do professor, qual era a participação e o desempenho do alunos durante as tarefas das atividades propostas e qual 
era a conduta do participante. Após identificar esses dados foi possível iniciar as tarefas 2, 3, 4, 5 para a prescrição e confecção dos recursos de tecnologia assistiva na escola.

A criança com deficiência na Educação Infantil tem o direito de usufruir de uma abordagem pedagógica que enfatiza o direito de ser criança, brincar e vivenciar experiências significativas para o seu desenvolvimento de forma lúdica e informal (MELLO, 2004, 2007; LEONTIEV, 1991; BRASIL, 2003).

A área de tecnologia assistiva pode oferecer condições para que os alunos com paralisia cerebral possam participar da rotina de atividades estabelecidas pela escola: brincadeiras, jogos, tarefas pedagógicas entre outras. Os serviços e recursos da tecnologia assistiva podem colaborar promovendo estratégias para que o aluno tenha uma relação rica com o outro e com o meio (CONNERS; JOHNSON, 2001; BARNES; TURNER, 2001; MANZINI; SANTOS, 2002; DELIBERATO, 2004, 2009a, 2009b; COPLEY; ZIVIANI, 2004; BERSCH, 2006; JUDGE; FLOYD; JEFFS, 2008; ROCHA et al., 2008, ROCHA; DELIBERATO, 2009a, 2009b; PELOSI, 2006, 2008, 2009; GALVÃO FILHO, 2009).

Para contemplar o objetivo final deste trabalho foram planejadas tarefas e procedimentos para construção de recursos de tecnologia assistiva a fim de atender às necessidades do aluno no contexto escolar perante a proposta de Manzini e Santos (2002).

Para isso foi necessário: Tarefa 2 - pensar no recurso; Tarefa 3 - escolher as alternativas; Tarefa 4 - representar a idéia; e Tarefa 5 - confeccionar os recursos. Todas as tarefas serão descritas a seguir.

\subsection{Resultados e discussões da Tarefa 2: Pensar no recurso de tecnologia assistiva}

Segundo Cook e Hussey (1995, 2002), ao pensar no recurso de tecnologia assistiva é importante conhecer as características individuais da criança, identificar as necessidades especificas das atividades planejadas em diferentes contextos e estabelecer os recursos e serviços da tecnologia assistiva a serem utilizados. A soma destes três aspectos irá favorecer a confecção de recursos de tecnologia assistiva para a criança com paralisia cerebral. $\mathrm{O}$ recurso e as estratégias adequadas para viabilizar o seu uso, podem proporcionar melhor desempenho durante as atividades, ampliação de sua comunicação, maior autonomia e a aquisição de novas habilidades (PERES, 2003; SORO-CAMATEZ, 2003). 
A tarefa de gerar ideias sobre os recursos de tecnologia assistiva para o contexto escolar, ou seja, pensar em recursos que poderiam favorecer a aprendizagem significativa do aluno com paralisia cerebral, foi fundamentada em três elementos norteadores: as características do aluno com deficiência, planejamento do professor e o desempenho dos alunos da sala frente ao planejamento do professor.

A utilização de parâmetros que levam o profissional a entender o contexto da criança antes da prescrição do recurso pode ser uma estratégia para ajudar na sua escolha e inserção da tecnologia assistiva (JUDGE; FLOYD; JEFFS, 2008).

Manzini (2005), relatou que após entender a situação do aluno é possível relacionar as características deles com um possível recurso a ser confeccionado. Após os dados identificados na Tarefa 1, e os elementos que nortearam a tarefa 2 foi possível identificar informações para a confecção de recursos de tecnologia assistiva.

Durante a tarefa 1 foi possível observar que os recursos mais utilizados pelo participante A foram brinquedos como bolas, carrinhos, e brinquedos para areia, essas atividades faziam parte do planejamento do professor e contemplavam as necessidades da faixa etária das demais crianças da sala do aluno. Também foi identificado o interesse do participante A por música.

Os dados referentes ao Participante B demonstraram que os recursos mais utilizados pela professora são aqueles que apóiam o processo inicial da alfabetização como o caderno, o lápis, o estojo, a lousa, textos digitados, cola, livros, DVDs, lápis de cor e giz de cera.

Esta diferença entre os recursos utilizados pelas professoras durante as atividades, além de se justificar pela diferença entre as idades dos participantes pode estar relacionada a outros dois fatores: o maior comprometimento das crianças da classe especial, e também a demanda de conteúdo pedagógico da sala de aula do participante B.

Apesar das professoras desenvolverem estratégias para maior participação da criança nas atividades, os procedimentos não foram suficientes para garantir a acessibilidade dos participantes para o uso dos recursos que estão presentes na escola, ou seja, os recursos que não estão adequados às necessidades do aluno.

Também foi possível identificar na tarefa 1 que apesar da escola oferecer recursos para o posicionamento do Participante A, esses recursos não eram específicos para ela, fato que também prejudicou a realização das atividades planejadas pela professora, pois os recursos de posicionamento não proporcionaram a adequação postural necessária para a realização das tarefas. 
Quanto ao participante B apesar do recurso para posicionamento ser de uso pessoal, observou-se que o mesmo também não estava adequado às suas necessidades, dificultando as atividades, principalmente as que necessitavam do uso de membros superiores e atenção direcionada.

Este conjunto de situações, não favorecia o desempenho dos alunos no contexto escolar. No Participante A foi observado dificuldades no desempenho motor, comunicativo e perceptivo, e apesar do desejo que o aluno apresentava em realizar as atividades o ambiente, os recursos e as estratégias não estavam adequados, o que dificultava a sua participação e evidenciava ainda mais suas limitações.

O Participante B apresentou significativo comprometimento no desempenho motor e comunicativo, e também não conseguiu participar com autonomia nas atividades planejadas pela professora.

Os dados observados sobre os participantes A e B podem estar relacionados aos resultados descritos na pesquisa de Copley e Ziviani (2004), que identificou os obstáculos no uso de recursos de tecnologia assistiva no contexto escolar. Entre as principais dificuldades encontradas pelo professor estavam as avaliações e os processos de planejamento inadequados, dificuldades de gestão e aquisição de recursos, financiamento insuficiente, limitações do tempo, a falta de uma adequada formação dos profissionais e a falta de uma equipe de apoio.

Manzini (1999), considerou que o elemento central do professor é o planejamento de atividades a partir de um determinado objetivo, que pode não ser alcançado dependendo dos recursos utilizados na atividade.

Na situação vivenciada os recursos oferecidos aos participantes do estudo não estavam adequados às suas necessidades, o que impossibilitava os alunos de atingirm os objetivos das atividades planejadas pelas professoras. A participação do aluno durante as atividades era prejudicada, impedindo os participantes de vivenciarem experiências significativas importantes para o seu desenvolvimento e processo de aprendizagem.

Os professores devem planejar as atividades atendendo as necessidades de todos os alunos, neste caso específico, o professor do aluno com paralisia cerebral necessita além de planejar a atividade, pensar em recursos e estratégias adequadas a criança permitindo que ela participe em base de igualdade a seus pares (PELOSI, 2008; DELIBERATO, 2009a, 2009b; ROCHA; DELIBERATO, 2009a, 2009b; SAMESHIMA; DELIBERATO, 2009).

Como visto anteriormente neste trabalho o brincar é fundamental para a criança e segundo o Referencial Curricular Nacional para a Educação Infantil as brincadeiras são 
estratégias utilizadas na escola para garantir que a aprendizagem possa ocorrer (BRASIL, 1998).

Diversos foram os pesquisadores que estudaram o brincar (WINNICOT, 1971; VIGOTSKY, 1994; LORENZINI, 2002; TAKATORI, 2003; MOYLES, 2006; FERLAND, 2006; REIS; REZEND, 2007). Ferland (2006) identificou e agrupou alguns brinquedos utilizados por crianças em idade pré escolar. Com o intuito de relacionar os brinquedos com a faixa etária dessas crianças, a autora propõe a divisão de três grupos: 0 a 18 meses; 18 meses a 3 anos; e 3 a 6 anos.

É importante ressaltar, como foi visto na introdução deste estudo, que apesar das dificuldades da criança com deficiência física ela segue a mesma sequência de desenvolvimento do brincar das crianças típicas, porém é necessário adequar as relações entre o conteúdo e a forma de brincar, ou seja, é necessária a adequação dos recursos e estratégias para que a criança com paralisia cerebral possa participar dessas atividades.

Neste estudo o Participante A e B apresentavam três e seis anos respectivamente, assim considerou-se essencial durante essa tarefa referências teóricas que ajudassem na seleção de recursos apropriados para o processo de aprendizagem de cada aluno. Nessa perspectiva, foi utilizado como referência para seleção dos recursos os estudos de Ferland (2006), que como descrito anteriormente estabeleceu tipos de brinquedos de acordo com a faixa etária da criança pré-escolar.

Em relação ao Participante A foram selecionados os brinquedos da faixa etária de 18 meses a 3 anos, a pesquisadora optou em selecionar brinquedos desta faixa etária pois a criança tinha completado três anos recentemente. Para esta faixa etária Ferland (2006), agrupou os seguintes brinquedos: cubos, bolas, triciclo, brinquedos de encaixe, instrumentos musicais, papel e lápis de cera, massa de modelar, quebra cabeça, quadro negro, cavalinho, brincadeiras de parque e brinquedos de faz de conta como caminhão, carrinho, boneca, casinha.

Para o Participante B foram selecionados os brinquedos correspondentes a faixa etária de 3 a 6 anos, entre eles a autora citou: triciclo, papel, lápis, tesoura, livro de histórias, fantoches, fantasias, casa de bonecas, brinquedos de miniatura, carrinhos, bola de gude, canções de roda e jogos com regras simples (FERLAND, 2006).

Após a tarefa 1, é possível observar que os recursos oferecidos pelas professoras aos participantes do estudo se encontraram adequados a faixa etária de cada criança. Nessa perspectiva é importante ressaltar que o planejamento da professora contemplou os recursos necessários para as atividades do grupo de alunos da sala de aula da Educação Infantil. 
Também é fundamental lembrar que o planejamento do professor do aluno com paralisia cerebral deve oferecer recursos e estratégias para a realização das tarefas de cada atividade proposta.

Após identificar os brinquedos, foi definido que para a construção de recursos de tecnologia assistiva, seriam adaptados brinquedos para atividades similares as que estavam no planejamento do professor, ou seja, conhecidos pela criança no ambiente escolar.

A partir desse critério foram selecionados os seguintes recursos: participante A carrinhos, bolas, instrumentos musicais; participante B: comunicador em forma de relógio, acionador, jogo com letras e jogo de matemática.

Também surgiu a preocupação em relação ao posicionamento, sendo observado na Tarefa 1 que os dois participantes não conseguiam manter uma postura adequada para realizar as atividades propostas pela professora.

A adequação postural é capaz de facilitar os movimentos, possibilitando o uso mais adequado das mãos, a melhora e aumento do campo visual e coordenação visomotora, a melhora da atenção e concentração, e a melhora das condições para o aprendizado (RADELL, 1996; BRACCIALLI; MANZINI e VILARTA, 2005; BEUKELMAN; MIRENDA, 2007; BRASIL, 2007; BERSH, 2008; BRACCIALLI et al., 2008).

Em relação ao Participante A, optou-se por adaptar os mobiliários já presentes na escola, esta decisão considerou a quantidade significativa de mobiliários presentes na escola, além de serem recursos de custo elevado. Os mobiliários mesmo não sendo prescritos especificamente para a criança em estudo,podiam ser adaptados às suas necessidades, utilizando a própria regulagem do equipamento, além de cintos, mesas de apoio, almofadas e rolos presentes na escola (RADELL, 1996; BEUKELMAN; MIRENDA, 2007; BRACCIALLI; MANZINI e VILARTA, 2005; BRASIL, 2007; BERSH, 2008; BRACCIALLI et al., 2008).

Em relação ao posicionamento do membro superior do participante A, devido ao seu padrão flexor foi identificada a necessidade de órteses de posicionamento para punho, mãos e dedos (direita e esquerda) e órteses para a abdução do polegar (direita e esquerda).

Quanto ao participante B, optou-se por prescrever para a escola a necessidade de uma cadeira de rodas adaptada as necessidades posturais do aluno, a fim de promover alinhamento postural, estabilidade e conforto. A literatura descreve que estes elementos podem contribuir para a participação do aluno com paralisia cerebral nas atividades (RADELL, 1996; BERSH, 2007; BEUKELMAN; MIRENDA, 2007; BRACCIALLI et al., 2008). 
O alinhamento e a estabilidade postural são fundamentais para que a criança consiga explorar o meio, mantendo a atenção por tempo prolongado, e agindo de forma ativa. Os alunos com deficiência física apresentam necessidade de indicação de recursos que supram suas necessidades posturais, ou seja, assentos, encostos, cintos e demais equipamentos que promovam o alinhamento, a estabilidade e o conforto (BRASIL, 2007).

\subsection{Resultados e discussões da Tarefa 3: Escolher as alternativas}

Ao escolher as alternativas para a adaptação dos brinquedos foram priorizados os recursos de baixa tecnologia, pois os professores teriam maior acesso aos materiais necessários para estas adaptações e o custo desses recursos seria relativamente baixo quando comparado com os recursos de alta tecnologia (QUIST; LLOYD,1997; WASSON, ARVIDSON, LLOYD, 1997; SORO CAMATES, 2003; SUÀREZ, et al. 2003; ANSON, 2007, BRACCIALLI, 2007).

Segundo Braccialli (2007) e Pelosi (2006), os recursos de baixa tecnologia são os equipamentos com pouca sofisticação e confeccionados com materiais de baixo custo disponíveis no dia a dia. Estes equipamentos são produzidos de maneira mais artesanal e individualizados. Este tipo de recurso pode ser confeccionado pelos próprios familiares do usuário ou por profissionais envolvidos. No Brasil existe uma predominância na indicação e confecção de equipamentos de baixa tecnologia.

Os recursos de baixa tecnologia na escola de Educação Infantil são capazes de atender demandas especificas nas atividades planejadas pelo professor do aluno com paralisia cerebral, o que é fundamental para garantir a acessibilidade para o seu processo de aprendizagem.

Como exemplo, Galvão Filho (2009), enumerou recursos de tecnologia assistiva de baixo custo que poderiam estar presentes em salas de aula: suportes para visualização de textos ou livros; fixação do papel ou caderno na mesa com fitas adesivas; engrossadores de lápis ou caneta confeccionados com esponjas enroladas e amarradas, ou com punho de bicicleta ou tubos de PVC; substituição da mesa por pranchas de madeira ou acrílico fixadas na cadeira de rodas; órteses; entre outras. 
Os recursos de baixa tecnologia podem ser construídos pelos próprios professores com materiais da própria escola (BRASIL, 2006). Os profissionais que estão capacitados a confeccionar os recursos de tecnologia assistiva de baixo custo podem adequar o recurso as necessidades do aluno, para que ele tenha a oportunidade de melhorar o seu desempenho e consequentemente sua participação em sala de aula.

Outro fator fundamental para o uso do recurso de tecnologia assistiva no contexto escolar é que o equipamento deve estar disponível para atender as atividades do planejamento do professor. Neste sentido os recursos de baixa tecnologia podem ser confeccionados em tempo compatível com a necessidade do professor, pois geralmente são construídos de forma artesanal e tem um custo inferior aos recursos de alta tecnologia (BRACCIALLI, 2007; PELOSI, 2008; ROCHA et al, 2008; GALVÃO FILHO, 2009).

\subsection{Resultados e discussões Tarefa 4: Representar a idéia}

Antes de confeccionar os recursos de tecnologia assistiva foi necessário pensar nas características físicas dos materiais utilizados, considerando o desempenho motor, visual, auditivo e comunicativo do aluno com paralisia cerebral.

A literatura apontou que a ação de adaptar um recurso promove ajuste, acomodação e adequação do indivíduo a uma nova situação, e as respostas adaptativas dependem de alguns fatores como: satisfação; sucesso do desempenho ocupacional; negociações positivas e negativas entre a pessoa e o ambiente (TEIXEIRA; ARIGA; YASSUKO, 2003).

Reganhan (2006), ressaltou que para a adaptação de recursos, a forma, o tamanho e a textura são importantes para as crianças com deficiência física e visuais, considerando as próprias características da paralisia cerebral.

O participante A deste estudo apresentava diagnóstico médico de paralisia cerebral, apresentado um quadro motor de tetraparesia espástica, com predomínio de padrão flexor em membros superiores. Sabe-se que esse quadro motor dificulta o manuseio de recursos pelo aluno, principalmente para o alcance e a preensão de objetos. Assim é fundamental que antes de realizar a adaptação dos recursos se estabeleça as características físicas do material facilitando a sua exploração pelo aluno.

Quanto ao participante B, é possível observar uma variação no grau de tensão dos músculos das extremidades do corpo, levando à realização de movimentos involuntários 
difíceis de controlar. O participante apresentou dificuldades em realizar atividades escolares através de movimentos voluntários, portanto é necessário pensar em materiais que possam facilitar o manuseio dos recursos a serem construídos.

Para contemplar estas necessidades foi utilizado o Protocolo de Caracterização e Dimensões do Recurso, tendo o objetivo identificar as necessidades do aluno com paralisia cerebral em relação às características e dimensões do recurso a ser confeccionado. Esse protocolo facilitou a escolha de materiais adequados para a confecção de recurso da tecnologia assistiva para a criança com paralisia cerebral. A seguir serão descritas as características dos protótipos de cada recurso que foi confeccionado:

\section{Participante A}

1) Bola: seu tamanho foi compatível com a mão do aluno, facilitando o mecanismo de pegar e soltar; em relação à textura não poderia ser de material liso, pois este tipo de textura poderia dificultar a manutenção da preensão do objeto, deveria ser leve e no momento em que o aluno realiza-se a preensão o material deveria ceder, ou seja ter uma consistência que molda-se à sua mão. Para a apresentação do material foi pensado em um suporte em plano inclinado, próximo ao aluno, com velcro para fixar a bola e facilitar o manuseio da criança. Também foi considerada a dificuldade visual da criança, pensando no objeto com cores contrastantes a fim de facilitar a visualização do brinquedo.

2) Carrinhos: visto que era incompatível para a criança o manuseio do brinquedo de forma convencional, foi criado uma forma para que o aluno pudesse brincar tendo a máxima autonomia, além de tornar a atividades significativa. Partindo desse objetivo foi pensado em acionadores que aclopados a carrinhos com sistema on/off permitiriam que a criança tivesse a autonomia de acessar o funcionamento do brinquedo. Foram selecionados brinquedos que emitissem sons, pois devido à dificuldade visual apresentada pela criança, o som no momento da atividade lúdica permitiria que o aluno utiliza-se suas habilidades auditivas e localiza-se o carrinho mesmo quando ele estivesse distante. 
3) Instrumentos musicais: foi pensado na adaptação de um chocalho com materiais reciclados, sendo que seu tamanho deveria ser adequado à mão da criança, leve, e possuir contraste de cores.

4) Acionador: Foi determinado que os acionadores fossem ativados através de pressão, deveria ter cores também com contrastes e dimensões que facilitassem o manuseio através do tato para a criança poder também reconhecer as características físicas do recurso.

5) Órteses membros superiores: foi indicada quatro órteses de membros superiores, duas para posicionamento de punho, mãos e dedos (direita e esquerda) e duas para a abdução do polegar (direita e esquerda). A órtese de posicionamento de punho, mãos e dedos é indicada para posicionar o membro superior da criança, o objetivo desse recurso é proporcionar repouso por meio do posicionamento articular. A órtese para abdução do polegar é indicada para criança com paralisia cerebral com objetivo de proporciona funcionalidade por meio da abertura do polegar. As órtese foram confeccionadas em material termoplástico de baixa temperatura, o que permitiu a modelagem e confecção diretamente na mão afetada respeitando as diferenças anatômicas individuais.

\section{Participante B}

1) Jogo de letras: o jogo foi confeccionado em um apoio resistente, aproximadamente do tamanho de um sulfite. Era formado por figuras de animais impressas de fácil identificação e espaço reservado para que o aluno pudesse colocar as letras correspondentes ao nome do animal. O espaço onde as para a colocação das letras foram marcados com o objetivo de facilitar a orientação espacial no papel. As letras tinham um formato plano a fim de facilitar o manuseio pela criança. Para facilitar a identificação foram utilizadas letras maiúsculas impressas em preto, da mesma forma que a professora oferecia as atividades na sala.

2) Jogo de matemática: foi confeccionado um jogo com o objetivo de apoiar o aluno durante as atividades de matemática, assim seria foi necessário um apoio resistente, onde seriam colocadas figuras que o aluno poderia manipular com o 
objetivo de realizar operações matemáticas simples. As figuras também foram de material resistente e plano a fim de facilitar o manuseio pela criança.

3) Comunicador em forma de relógio: devido à dificuldade da criança em se comunicar foi pensado em um recurso que possibilitasse a criança dar sua resposta com autonomia. O seu funcionamento é semelhante ao de um relógio, só que a criança comanda o movimento do ponteiro apertando um acionador, podendo desta forma indicar o que deseja.

4) Acionador: este recurso deveria ser utilizado junto ao comunicador em forma de relógio a fim de possibilitar apontar o que deseja. No caso do Participante B, o acionador deveria ser ativado através de pressão, ou seja, quando o aluno apertasse o acionador conseguiria a ação desejada. $\mathrm{O}$ acionador poderia ser confeccionado com uma caixa de DVD, dispositivos para acionar, plugs, fios e para o acabamento seria usado EVA azul.

\subsection{Resultados e discussões Tarefa 5: Confecção dos recursos de tecnologia assistiva}

Após as tarefas 1, 2, 3 e 4, foram confeccionados os recursos de tecnologia assistiva de acordo com as necessidades da criança com paralisia cerebral no contexto da Educação Infantil. Para a confecção dos recursos foram tomadas algumas precauções como não utilizar materiais com pontas aguçadas, bordas cortantes e peças pequenas. Estes cuidados tiveram a finalidade de garantir a segurança do aluno e a eliminação de fatores de risco para o uso dos recursos. A seguir os recursos de tecnologia assistiva confeccionado serão descritos individualmente:

\section{Participante A}

\section{1) Bola}


Foram adquiridas duas bolas pequenas revestida com napa, recheada de espuma, o que permitia grande flexibilidade para a adequação a mão da criança no movimento de preensão. As bolas são de cor amarela e em um de seus lados estão elementos que imitam um rosto, tendo olhos, nariz e boca nas cores pretas e vermelhas, permitindo o contraste.

A partir da análise do desempenho da criança nas atividades durante a observação foi possível aferir a dificuldade que ela apresentava em buscar os objetos com as mãos, então no lado contrário ao desenho do rosto na bola foi colado um pedaço de velcro auto-adesivo com a intenção de fixá-la em um plano inclinado para facilitar o acesso da criança ao brinquedo.

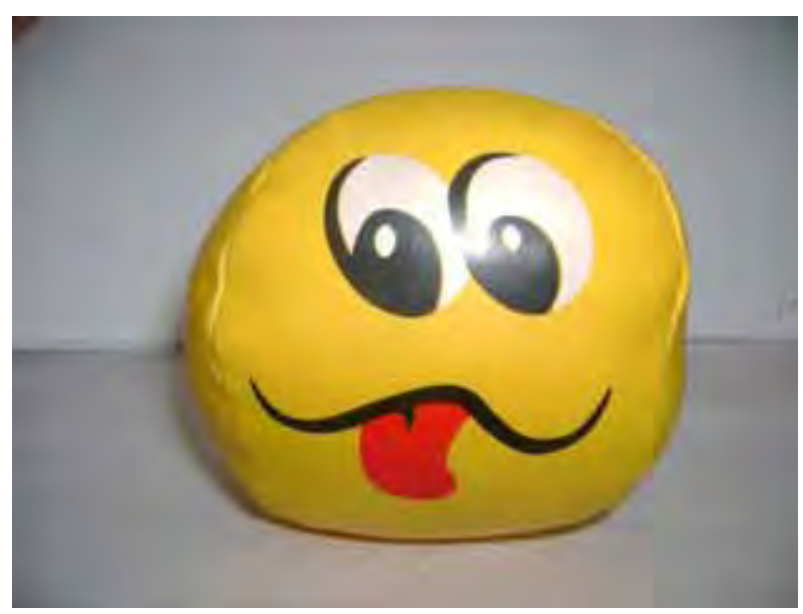

Figura 4 Bola

\section{2) Carrinhos}

Três carrinhos com interruptores (mecanismo ON/OFF) adquiridos em lojas foram adaptados através da introdução de plugs em seu mecanismo interno. Para realizar esta adaptação foi necessário: Plugs de encaixe; cabo de rede com fios de cobre; instrumentos para solda e furadeira com graduação de velocidade.

Para a adaptação a extremidade oposta de cada um dos fios soldados ao plug foi soldada ao pólo correspondente do interruptor do brinquedo. Com a furadeira foi feito um furo em uma das extremidades do brinquedo para que o plug fosse fixado. Este mecanismo permite conectar o acionador ao plug, e assim acessar o brinquedo realizando pressão sobre o acionador. 


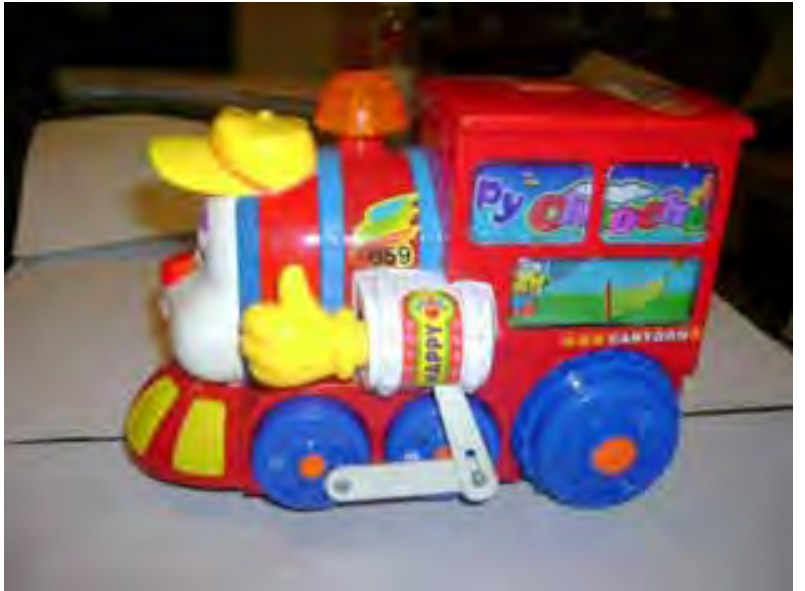

Figura 5 Trem adaptado

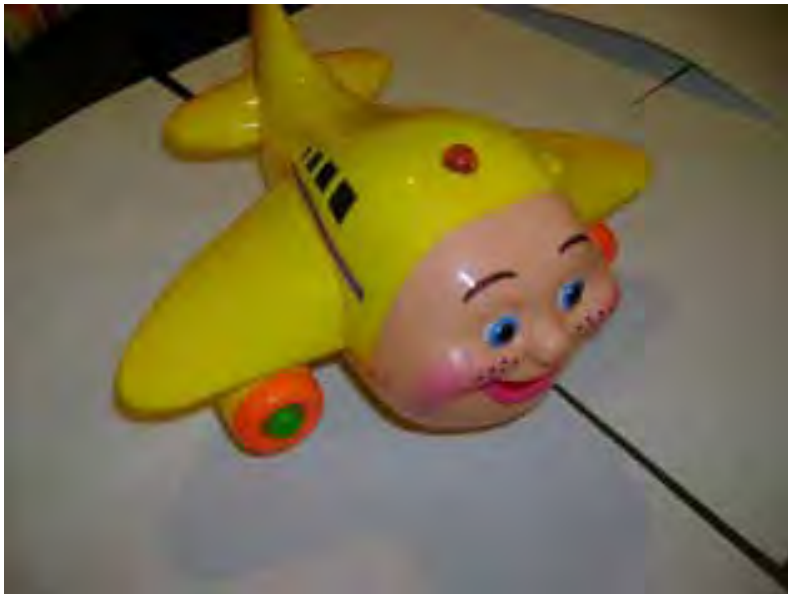

Figura 7 Avião adaptado

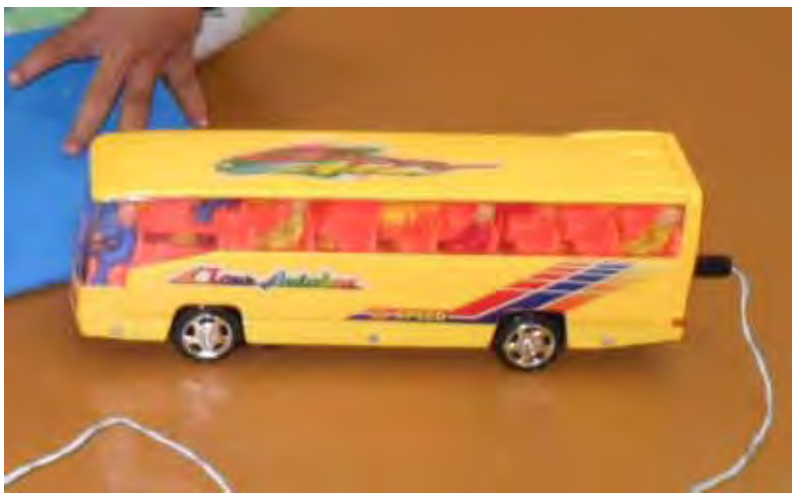

Figura 9 Ônibus adaptado

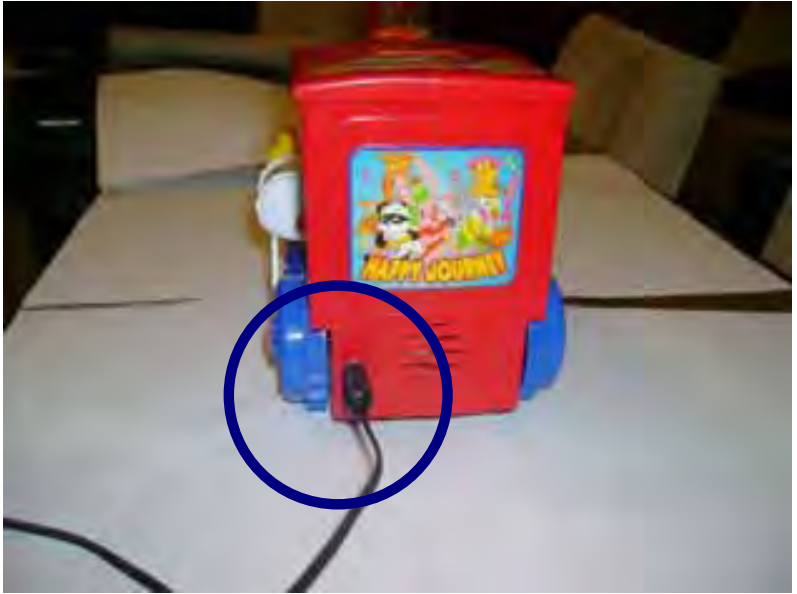

Figura 6 Plug para entrada do acionador

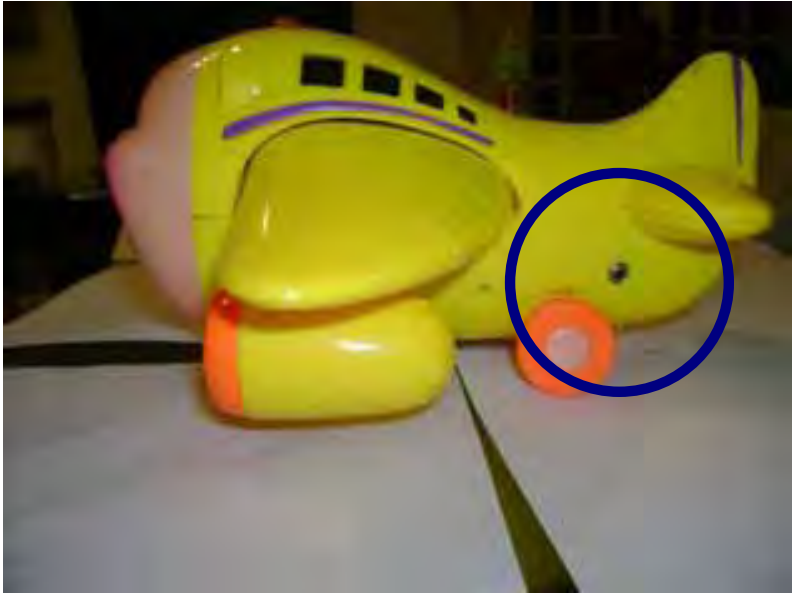

Figura 8 Plug para entrada do acionador

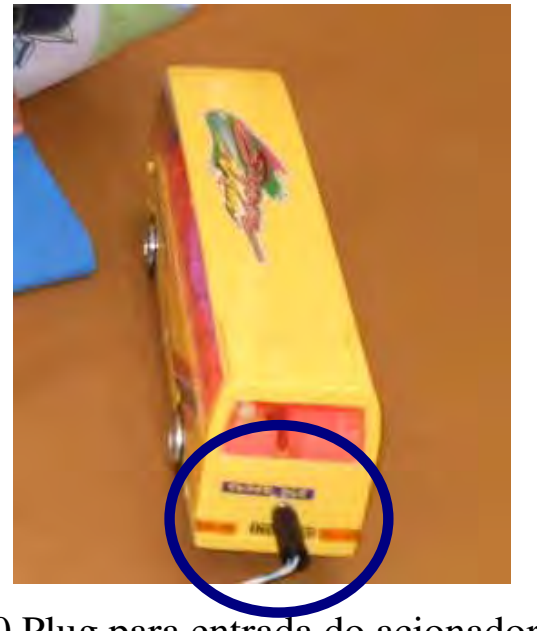

Figura 10 Plug para entrada do acionador 


\section{3) Acionador}

Acionadores são recursos que servem de interface entre o usuário e o equipamento, permitem a acessibilidade do deficiente físico em diferentes atividades, como por exemplo: o acionamento de brinquedos adaptados; o uso do computador, sendo possível comandar programas que possuam função de varredura como o power point; em atividades de vida diária, através do acionamento de eletrodomésticos adaptados. Do ponto de vista elétrico, um acionador é uma chave de contato momentâneo normalmente aberto, como um botão de campainha e possui um plug para que ocorra a conexão ao recurso adaptado. Pode ser comprado ou confeccionado em diversos modelos e formatos, e pode ser acionado por diversos mecanismos como pressão, tração, sopro ou piscar dos olhos. A sua indicação é realizada a fim de ampliar as funcionalidades do usuário.

Após a identificação das necessidades da criança, foi concluído que devido à diminuição da amplitude de movimento dos membros superiores e a dificuldade de realizar movimentos de preensão, ela encontraria maior facilidade na extensão e flexão da articulação do punho, favorecendo o movimento de apertar e soltar, sendo prescrito o acionador de pressão, pois isso permitiria que a criança o controlasse com maior exatidão e com menor gasto de energia o acionador. Desta forma a criança pode comandar os brinquedos quando exercia alguma pressão (apertar e soltar) no acionador.

Foi então confeccionado um acionador, para isto uma chave micro Swith foi soldada na extremidade de um fio de aproximadamente 2 metros, e em seguida na outra extremidade foi soldado um plug que se encaixava ao plug já colocado no brinquedo. Após a confecção do fio, a extremidade com o Swith foi colada no centro do interior de uma capa de plástico para DVD, assim no momento que a criança apertasse a caixa de DVD, conseguiria acionar o brinquedo.

A caixa de DVD onde foi confeccionado o acionador foi revestida de EVA colorido a fim de facilitar a visualização do mesmo pela criança e também ter um visual que a atraísse sua atenção. 


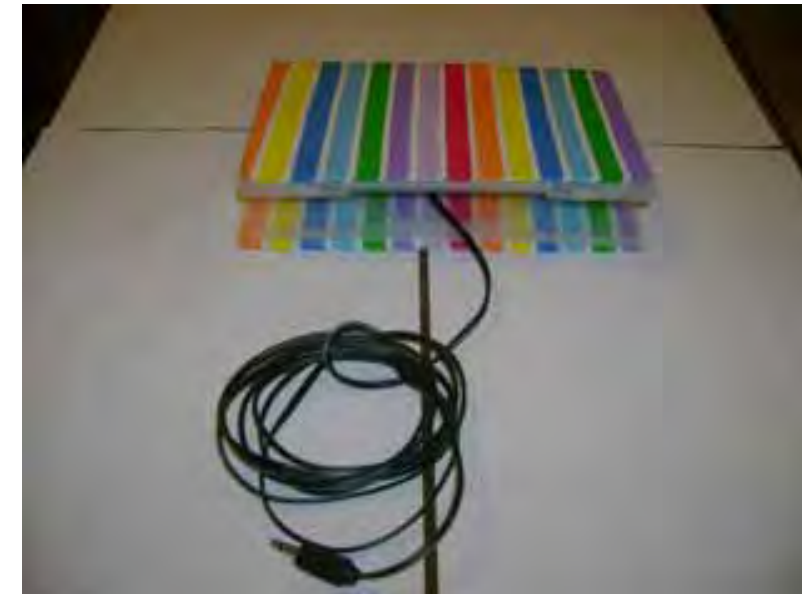

Figura 11. Acionador de pressão artesanal

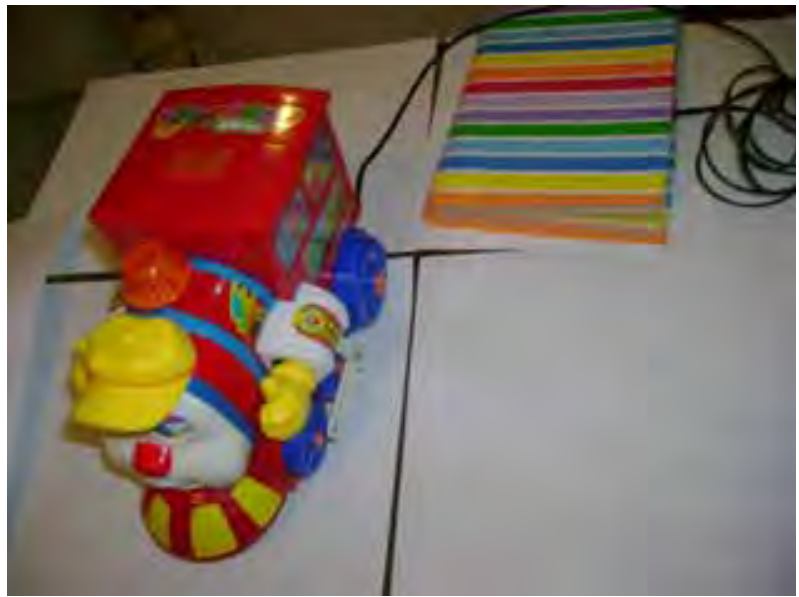

Figura 12. Acionador acoplado ao brinquedo

\section{4) Chocalho}

Foram confeccionados dois chocalhos com potes cilíndricos de iogurte medindo $5 \mathrm{~cm}$ de altura, foram forrados com fitas adesivas coloridas (vermelha e branca, e amarela e preta) para se obter o contraste de cores. Cada pote trouxe em seu interior tipo de objeto (arroz e feijão), com o intuito de produzir sons diferentes.

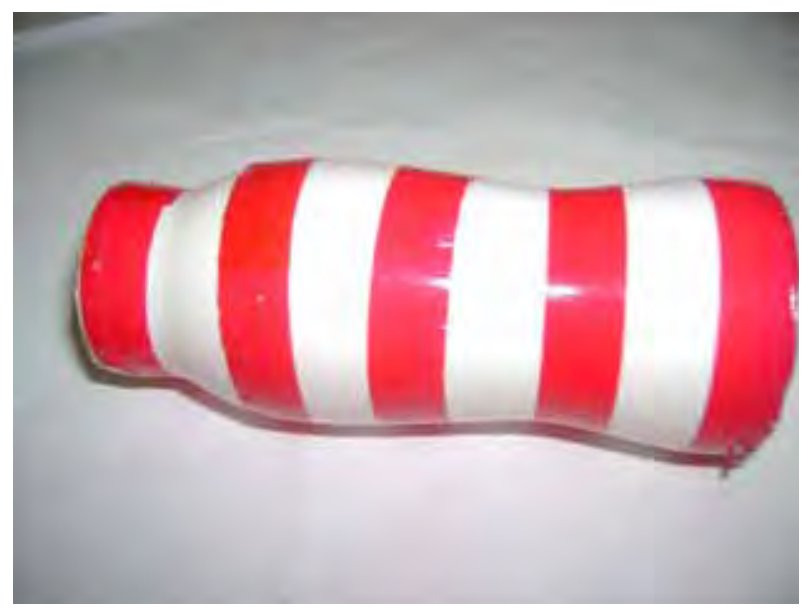

Figura 13. Chocalho 


\section{5) Órteses}

As órteses de posicionamento de punho, mãos e dedos são recursos que auxiliam no posicionamento do membro superior de crianças com paralisia cerebral com objetivo de controlar, preservar, modificar e aumentar a mobilidade articular e prevenir contraturas e deformidades. A órtese de abdução do polegar favorece o posicionamento funcional da articulação que forma a base do polegar (articulação trapézio-metacarpiana), e é indicada para crianças com paralisia cerebral com o objetivo de ampliar a abertura do espaço existente entre o polegar e o dedo indicador proporcionando a maior habilidade para a manipulação de objetos.

As órteses devem estar adequadas às necessidades do paciente, e devem preferencialmente ser confeccionadas sob medida por profissionais como terapeutas ocupacionais e fisioterapeutas respeitando as características anatômicas individuais. Após sua confecção, é necessário um acompanhamento com observação criteriosa do profissional quanto à melhora do padrão funcional ou possíveis intercorrências como a presença de pontos de pressão. O envolvimento da criança e da família é fundamental quanto ao benefício obtido.

Para o participante A após a avaliação da necessidade de órteses de posicionamento de membros superiores direito e esquerdo (Figura 10), e de órteses para a abdução do polegar direito e esquerdo (Figura 11), foi agendado um dia para que o mesmo fosse até um centro de reabilitação para que a pesquisadora confeccionasse o recurso. Quanto à sua confecção foram feitos moldes em tecido da mão da criança e posteriormente esses moldes foram reproduzidos em material termoplástico. Após esse procedimento termoplástico, foi recortado foi colocado em água fervente para que o material ficasse flexível e moldasse na própria mão do aluno. Após o molde das órteses foram feitas as medidas para colocar as faixas de velcro que proporcionaram o apoio do recurso na mão do aluno.

Após a confecção das órteses devem ser realizadas orientações sobre a sua utilização. Para esse participante a órtese de posicionamento de punho, mãos e dedos foi indicada para o uso noturno e a órtese de abdução do polegar deve ser utilizada durante o dia para facilitar as atividades da criança. 


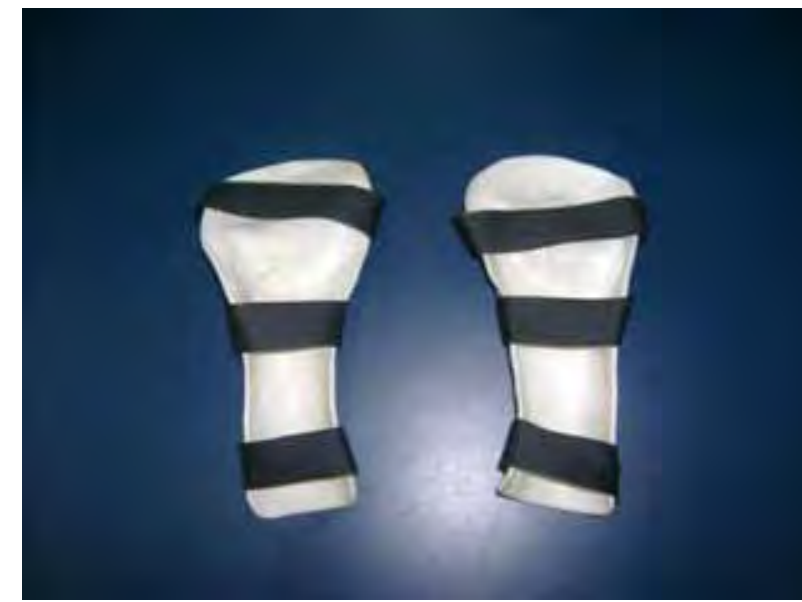

Figura 14 Órteses de posicionamento

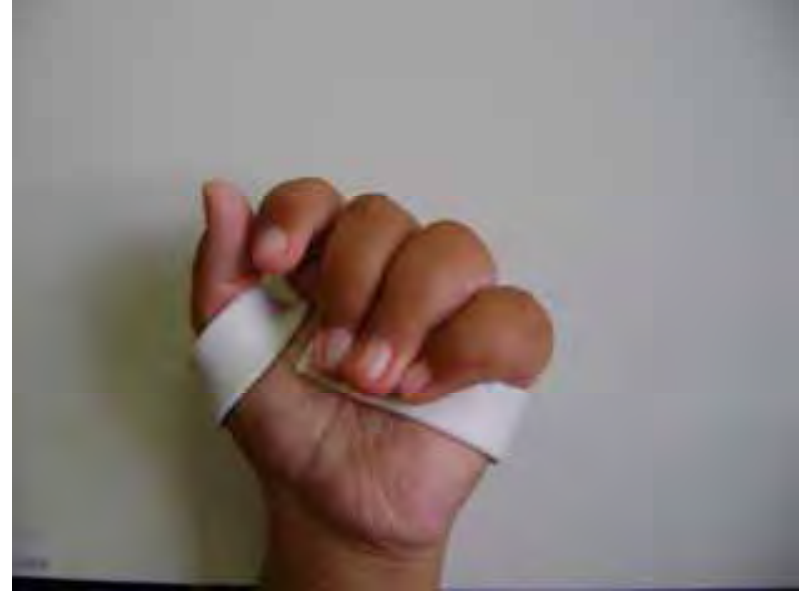

Figura 15. Órtese para abdução do polegar

\section{Participante B}

\section{1) Jogo das Letras}

Foram confeccionados 14 tabuleiros com o tema de animais, sendo que em cada uma deles tinha a figura de dois, totalizando 28 animais. As figuras foram impressas em papel sulfite e posteriormente a folha foi plastificada. Através do mesmo processo foram confeccionadas letras do alfabeto com o tamanho de $5 \mathrm{~cm}$ de largura por $5 \mathrm{~cm}$ de altura para que a criança pudesse escrever o nome dos animais. As letras utilizadas foram maiúsculas na cor preta, pois foi observado durante a Etapa 1 que a as atividades propostas pela professora utilizavam esta configuração. O material foi plastificado, pois além de melhorar a resistência e durabilidade, visto que a criança possuía movimentos involuntários permite uma melhor higienização.

Para a fixação das letras no tabuleiro foi utilizado velcro autocolante, sendo que no tabuleiro foi colocado um pedaço para cada letra a ser representada, sendo o mesmo feito com as letras do alfabeto. Este procedimento de utilizar um pedaço de velcro para cada letra teve o objetivo de auxiliar o aluno na coordenação visomotora, na noção espacial e na sequenciação.

Este recurso teve como objetivo auxiliar na alfabetização, considerando que o participante B não possui habilidade de coordenação motora fina para trabalhar com lápis e papel. Através do uso dos recursos espera-se que o aluno possa reconhecer e memorizar as letras do alfabeto e iniciar a formação de palavras. Outro aspecto que esses recursos devem 
favorecer é a atenção do aluno, pois tendo autonomia poderá ampliar seu interesse e sua motivação pela atividade.

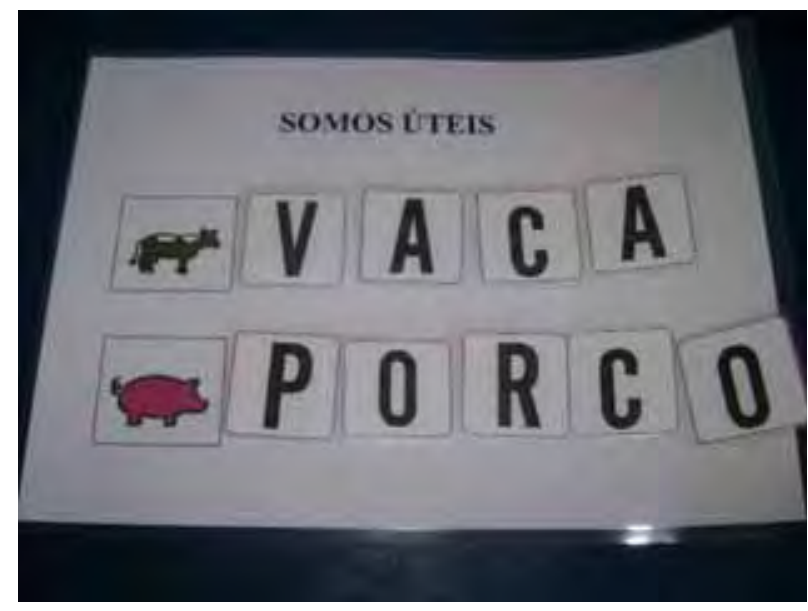

Figura 16 - Tabuleiro do Jogo das Letras

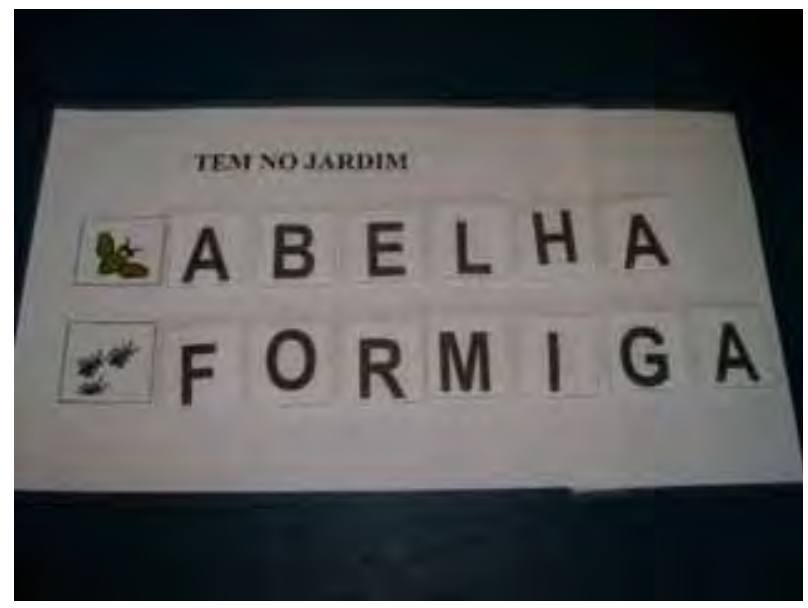

Figura 17 - Tabuleiro do Jogo das Letras

\section{2) Comunicador em Forma de Relógio}

O comunicador em forma de relógio tem o objetivo de possibilitar a criança dar sua resposta com autonomia, mesmo que ela apresente uma dificuldade motora e/ou necessidades complexas de comunicação. Seu funcionamento é semelhante ao de um relógio, só que a criança comanda o movimento do ponteiro apertando um acionador.

Em relação ao participante $B$ optou-se em utilizar um comunicador em forma de relógio adquirido em lojas de produtos de reabilitação, pois devido aos constantes movimentos involuntários foi priorizado por um material mais resistente.

Além de possibilitar ao aluno autonomia em suas escolhas, é esperado que este recurso favoreça uma melhor postura, a simetria de tronco, o uso das mãos e a ampliação seu campo visual.

Este recurso também tem o objetivo de favorecer a ampliação das habilidades comunicativas, conseguindo assim uma maior participação nas atividades em sala de aula. 


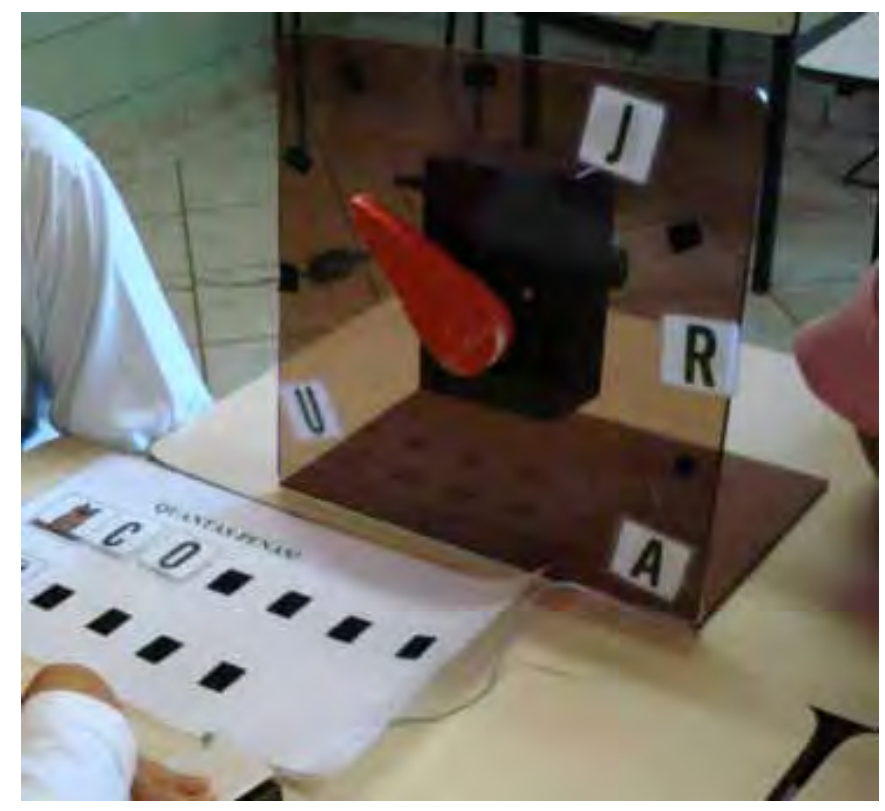

Figura 18 - Comunicador em Forma de Relógio

\section{3) Acionador}

O acionador foi confeccionado para o participante B com o objetivo de controlar o comunicador em forma de relógio. Após a identificação das necessidades da criança, pode-se afirmar que devido aos movimentos involuntários e a dificuldade de realizar movimentos de preensão o acionador indicado também seria o acionador de pressão, portanto através do movimento de apertar e soltar a sua superfície é possível ativar o comunicador.

Foi então confeccionado um acionador semelhante ao acionador do participante A, assim uma chave micro Swith foi soldada na extremidade de um fio de aproximadamente 2 metros, e em seguida na outra extremidade foi soldado um plug que se encaixava ao plug, porém este era colocado no comunicador em forma de relógio. Após a confecção do fio, a extremidade com o Swith foi colada no centro do interior de uma capa de plástico para DVD. Após este procedimento foi utilizado EVA azul para dar o acabamento na superfície do acionador.

$\mathrm{O}$ acionador junto ao comunicador em forma de relógio e o jogo de letras é uma alternativa para se iniciar a escrita da criança, através desses recursos ela pode apontar letras e consequentemente formar palavras, atividade que não conseguia fazer de forma convencional. 


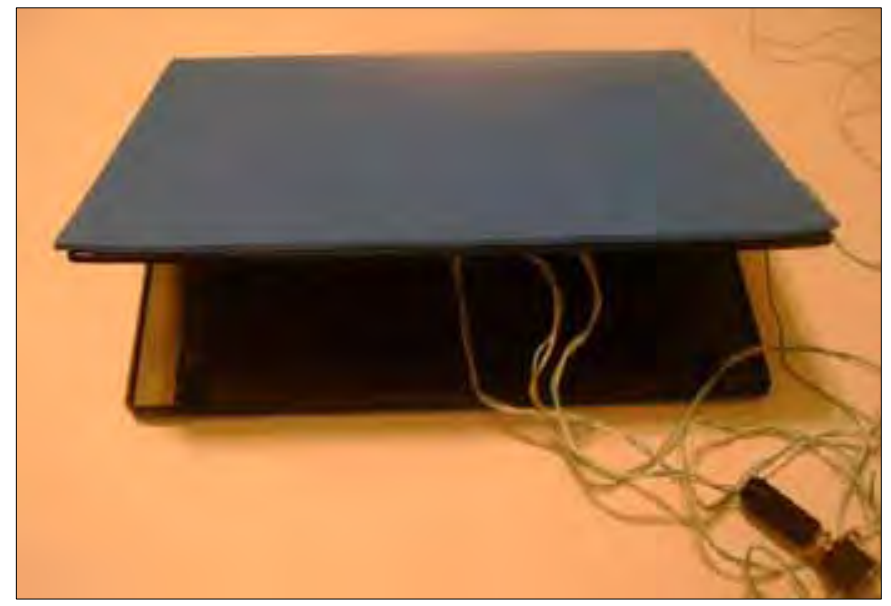

Figura 19 - Acionador

\section{4) Jogo de matemática}

Este jogo teve como objetivo promover a autonomia da criança durante as atividades de matemática em sala de aula, pois durante a observação foi verificado que a professora utiliza palitos de sorvete para apoiar as atividades, porém o aluno não consegue manuseá-los com independência.

Desta forma foi planejado um tabuleiro onde foi impressa uma árvore em uma folha de papel tipo A2 (42,0 x 59,4 cm) e em seguida plastificada. Posteriormente foram impressas 12 figuras de maçãs em quadrados de $3 \mathrm{~cm}$ de uma folha de sulfite tipo A4, em seguida a folha foi plastificada e colada em um EVA verde de espessura de 1,2 cm, após estes procedimentos os quadrados foram recortados. Para a fixação foram utilizados 12 pedaços de velcro autocolante na superfície do tabuleiro e 12 nas figuras. Para a melhor utilização desta atividade ela deverá ser fixada em um plano inclinado na altura dos olhos da criança.

Durante as atividades de matemática a criança deve efetuar de forma concreta as operações matemáticas propostas pela professora através das figuras, podendo adicionar ou retirar as maçãs conforme o comando da operação. Este processo visa o desenvolvimento do raciocínio lógico, além de auxiliar no conhecimento dos numerais e na noção de quantidade.

Apesar de estar sendo confeccionada para uma criança com deficiência física esta atividade pode ser utilizada com todos os alunos, substituindo o uso dos palitos de sorvete. 


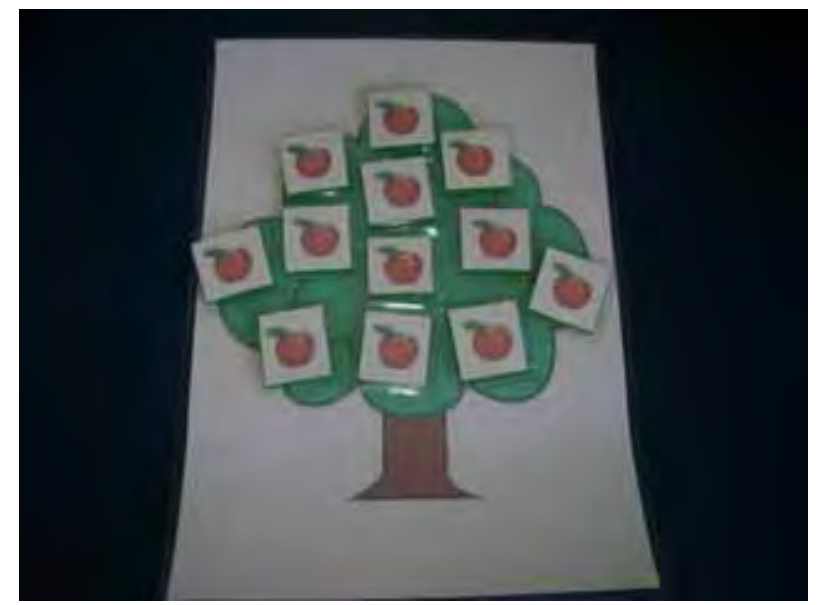

Figura 20 - Jogo de Matemática

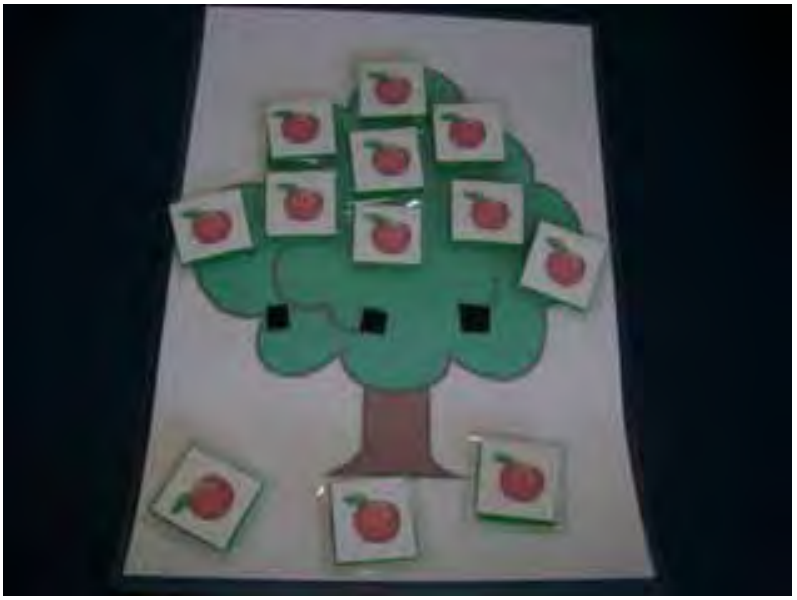

Figura 21 - Jogo de Matemática

As tarefas 2, 3, 4 e 5 facilitaram o processo de confecção dos recursos de tecnologia assistiva para ambos os participantes desta pesquisa. A descrição dos recursos apresentados pode facilitar o entendimento do modelo proposto por Manzini e Santos (2002) para que professores de alunos com deficiência possam utilizá-los. Cabe ressaltar que o fato dos modelos de recursos estarem descritos e representados, os profissionais devem estar atentos às características individuais de seus alunos, ou seja, os professores poderão seguir esta proposta, mas adequando os recursos ou ainda utilizar os recursos aqui propostos, mas adequando as estratégias. 


\section{CONCLUSÕES}

1. Por meio dos procedimentos estabelecidos foram confeccionados os seguintes recursos de tecnologia assistiva: duas bolas, três carrinhos, 2 acionadores, 2 chocalhos, 4 órteses, 1jogo de letras com 14 tabuleiros, 1 comunicador em forma de relógio e 1 jogo de matemática.

2. Os recursos de tecnologia assistiva foram elaborados por meio de tarefas sistematizadas envolvendo o professor.

3. As informações obtidas por meio do relato dos professores favoreceram a descrição das especificidades do aluno e do ambiente.

4. A caracterização dos alunos e do ambiente foi fundamental para a confecção dos recursos.

5. Os resultados demonstraram a importância da capacitação do professor não só para a confecção do recurso, mas para estabelecer as estratégias de uso dos materiais.

6. O ambiente da classe especial favoreceu a disponibilidade de recursos, mas não garantiu a generalização do uso dos instrumentos frente a rotina do professor.

7. O ambiente inclusivo favoreceu a interação do aluno com paralisia cerebral com outros interlocutores competentes em diversas habilidades.

8. O ambiente inclusivo não favoreceu a disponibilidade de recursos.

9. A atuação de serviços da tecnologia assistiva, como no caso a terapia ocupacional foi fundamental para a confecção dos recursos de tecnologia assitiva. 


\section{CONSIDERAÇÕES FINAIS}

O aluno com paralisia cerebral pode apresentar o seu desempenho comprometido durante as atividades pedagógicas considerando suas demandas motoras, comunicativas e perceptivas, nessa perspectiva a sua participação nas tarefas do contexto escolar são prejudicadas e seu processo de aprendizagem comprometido (TROMBLY, 1989, SOROCAMATS 2003; MANZINI; DELIBERATO, 2004, 2007; BERSH, 2008, PELOSI, 2008).

É necessário que os profissionais da escola busquem auxílios que possam suprir as necessidades deste aluno e criar condições para ampliar suas habilidades no contexto escolar.A escola da Educação Infantil foi o ambiente focado no objetivo deste estudo, nesta perspectiva para atividade de confeccionar o recurso de tecnologia assistiva para o participante, foi necessário o desenvolvimento de tarefas com procedimentos para caracterizar o ambiente escolar e identificar as necessidades do aluno no contexto.

A Convenção sobre os Direitos das Pessoas com Deficiência, que ocorreu no ano de 2006, da qual o Brasil é signatário, desloca a ideia da limitação presente na pessoa para a sua interação com o ambiente (BRASIL, 2007).

Ao identificar a participação do aluno com paralisia cerebral focando o ambiente escolar, o conceito de necessidades educacionais especiais transfere a ênfase das incapacidades e desvantagens centradas no aluno para todo contexto escolar (BRASIL, 2006 b).

A tecnologia assistiva é capaz de oferecer serviços, recursos, estratégias para atender as especificidades dos alunos com deficiência física promovendo mudanças no contexto escolar, e assim tornar este ambiente de fato inclusivo. A supressão de barreiras através do uso da tecnologia assistiva no contexto escolar desloca as limitações para o ambiente e contribui para a acessibilidade do aluno com deficiência

É importante ressaltar que a inclusão do aluno com deficiência física e o fornecimento de recursos de tecnologia assistiva não são garantias para que o processo de aprendizagem ocorra de forma plena. Assim este estudo se propôs a refletir sobre quais as tarefas e procedimentos necessários para executar a atividade de confeccionar recursos de tecnologia assistiva na Educação Infantil. Para isto foi necessário identificar as características do aluno com paralisia cerebral, o planejamento do professor e o ambiente escolar. O uso do recurso de tecnologia assistiva na escola deve contemplar o planejamento do professor e favorecer as habilidades do aluno para que ele participe das atividades propostas neste planejamento. 
Para a confecção dos recursos de tecnologia assistiva foi necessário primeiramente entender a situação de todo contexto escolar, neste estudo o alunos foram os protagonistas deste processo, porém foi necessário perceber as demandas do ambiente e as necessidades do professor, só assim foi possível pensar em recursos com potencial pedagógico para proporcionar experiências significativas para o processo de aprendizagem do aluno.

Para entender a situação foram necessários vários procedimentos que viabilizassem o conhecimento das características pessoais, os desejos e o desenvolvimento do aluno; os ambientes da escola; os interlocutores mediadores, ou seja, os profissionais e colegas que se relacionam com o aluno na escola; os recursos presentes; as atividades propostas; as estratégias utilizadas pela professora; a participação do aluno; o seu desempenho motor, perceptivo e comunicativo. Para contemplar esta tarefa foram realizadas entrevistas com os professores, a identificação da rotina e a observação do contexto escolar dos participantes do estudo.

Após entender a situação do aluno no contexto escolar foi possível estabelecer as suas habilidades e necessidades e pensar nos recursos de tecnologia assistiva adequados ao planejamento do professor. Em seguida foram estabelecidas as alternativas viáveis e através delas representadas as ideias referentes ao recurso, posteriormente foi delineado um protótipo necessário para desenvolver a atividade de construção de recursos para o aluno com paralisia cerebral na Educação Infantil. Respeitar todas estas tarefas garante um recurso personalizado que atenda as necessidades do aluno e do professor.

É importante ressaltar que a participação do aluno em todas as atividades do contexto escolar é fundamental ao processo de aprendizagem, e é direito da criança ter acesso a recursos que favoreçam essa participação.

Este trabalho mostrou a necessidade de procedimentos para definir de fato quais são as necessidades individuais de cada aluno com paralisia cerebral e assim indicar os recursos de tecnologia assistiva e confeccioná-los.

É fundamental ressaltar que não é finalidade esgotar neste estudo todas as considerações possíveis sobre a tecnologia assistiva na Educação Infantil. Como já citado anteriormente é necessário avaliar o uso dos recursos e acompanhar a sua utilização no contexto escolar. Apesar de todas essas tarefas serem contempladas durante a coleta de dados com os participantes do estudo, conforme orientações de Manzini e Santos (2002), os dados não foram apresentados neste estudo devido a sua extensão e complexidade.

Este trabalho deve ser um convite para que os profissionais possam repensar em como estão sendo implementado os serviços, recursos estratégias de tecnologia assistiva na escola. 
Durante a busca na literatura foram encontrados poucos trabalhos que abordavam este processo, fato que torna essencial novas discussões sobre as condições que envolvem o uso da tecnologia assistiva na escola, entre eles é possível sugerir: qual a formação do profissional que está atuando na escola para implementação dos recursos de tecnologia assistiva? Como está sendo realizada a capacitação do professor para conhecer e identificar a necessidade dos recursos e estratégias de tecnologia assistiva? $\mathrm{O}$ professor tem acesso a aquisição ou a possibilidade de confeccionar os recursos de tecnologia assistiva?

Também são restritos na literatura os trabalhos que avaliam o uso dos recursos de tecnologia assistiva no contexto escolar, e das estratégias utilizadas pelos professores e demais profissionais da efetivar o uso dos recursos de tecnologia assistiva. Diante desse fato, evidncia-se que existe a necessidade estudos que abordem estes temas para o aprimoramento dos serviços, recursos e estratégias no contexto escolar.

Além da preocupação em garantir o recurso ao aluno com deficiência na escola, é fundamental a capacitação dos professores e demais profissionais da escola, a fim de possibilitar estratégias e oportunidades para o aluno utilizá-lo. Somente esse conjunto de ações pode garantir a acessibilidade do aluno com deficiência física em todos os espaços e atividades escolares.

Para finalizar esta discussão faz-se necessário ressaltar também a necessidade de políticas publicas que favoreçam os serviços e recursos de tecnologia assistiva na escola a fim de possibilitar a acessibilidade do aluno com paralisia cerebral nesse ambiente. Não é de responsabilidade exclusiva de o professor identificar, prescrever, construir e criar estratégias para o uso da tecnologia assistiva no contexto escolar. É necessário o envolvimento de todos os profissionais da escola, dos demais alunos, das famílias e também de redes de apoio formadas por profissionais de diversos setores, , como os profissionais da saúde. Desta forma é possível direcionar ações a fim de construir um trabalho colaborativo fundamentado nas diretrizes propostas pela Educação Especial. 


\section{REFERÊNCIAS}

ABNT, NBR - 14350 e NBR 14350-2. Segurança de brinquedos de playground. Rio de Janeiro, 2004.

ALVES, V. A. Análise das modalidades expressivas de um aluno não falante frente a diferentes interlocutores durante a situação de jogo. 2006. 169 f. Dissertação (Mestrado em Educação) - Faculdade de Filosofia e Ciências, Universidade Estadual Paulista, Marília, 2006.

ANDRÉ, M. E. D. A. Texto, contexto e significados: algumas questões na análise de dados qualitativos. Caderno de Pesquisa., São Paulo, v. 45, p. 66-71, 1983.

ANSON, D. Tecnologia assistiva. In PEDRETTI; L.W.; EARLHY,M.B. Terapia ocupacional: capacidades práticas para as disfunções físicas. 5 ed. São Paulo: Roca, 2005. p. $276-295$.

AOTA - AMERICAN OCCUPATIONAL THERAPY ASSOCIATION. Statement fundamental concepts of Occupational Therapy: occupation, purposeful activity and function. Am J Occup Ther., United States, v.51, n.10, p.864 - 866, 1997.

ARAÚJO, R.C.T.; MANZINI, E.J. Recursos de ensino na escolarização do aluno deficiente físico. In: MANZINI E.J. (org.) Linguagem, cognição e Ensino do Aluno com Deficiência. Unesp, 2001, p.1-11.

ARAÚJO, R.C.T.; DELIBERATO, D.; BRACCIALLI; L.M.P. A comunicação alternativa como área de conhecimento nos cursos de educação e saúde. In: DELIBERATO, D.; GONÇALVES, M. J.; MACEDO, E. C. (Org.). Comunicação alternativa: teoria, prática, tecnologias e pesquisa. São Paulo: Memnon Edições Científicas, 2009a. p. 275-292.

ARNHEIM, R. Arte e percepção visual. São Paulo: Pioneira, 1997.

AUDI, M. Estudo Comparativo do Comportamento Motor de Membro Superior em Encefalopatas que Fazem Uso de Pulseira Estabilizadora. 2006. 112f. Dissertação (Mestrado em Educação) - Faculdade de Filosofia e Ciências, Universidade Estadual Paulista, Marília, 2006.

BAIN, B. K. Tecnologia assistiva. In: HOPKINS, H.L, SMITHHD. Wilard/Spackmam: Terapia ocupacional. 8 ed. Madri: Panamericana, 1998. p. 145 -161. 
BARDIN, L. Análise de conteúdo. Tradução de Luís Reto e Augusto Pinheiro. Lisboa: Edições 70, 2004.

BARNES, K. J.; TURNER, K. D. Team collaborative practices between teachers and occupational therapist. The American Journal of Occupational Therapy., United States, v.55, n.1, p.83-89, 2001.

BASIL, C. Introdução. In: ALMIRALL, C. B; SORO-CAMATS, E; BULTÓ, C. R. (Org.). Sistemas de sinais e ajudas técnicas para a comunicação alternativa e a escrita: princípios teóricos e aplicações. São Paulo: Editora Santos, 2003. p. 1-7.

BAZYK, J.; STALNAKER, D.L., EKELMAN, B. Play in Mayan children. The American Journal of Occupational Therapy., United States, v. 57, n.3, p. 273-283, 2003.

BEUKELMAN, D. R.; MIRENDA, P. Augmentative \& alternative communication: supporting children \& adults with complex communication needs. Baltimore: Paul H. Brookes Publishing, 2007.

BERSCH, R. Tecnologia assistiva e educação inclusiva. In: Ensaios Pedagógicos. Brasília: SEESP/MEC, 2006, p. 89-94.

Fatores humanos em tecnologia assistiva: uma análise de fatores críticos nos sistemas de prestação de serviços. Revista Plurais, Salvador: UNEB, v. 1, n. 1, p. 34-41, 2008.

Tecnologia Assistiva: recursos e serviços In: DELIBERATO, D.; GONÇALVES, M. J.; MACEDO, E. C. (Org.). Comunicação alternativa: teoria, prática, tecnologias e pesquisa.1 ${ }^{a}$ ed. São Paulo: MEMNON Edições Científicas, 2009a, v.1, p. 181-187.

BERSCH, R.; MACHADO, R. Auxílio em atividades de vida diária: material escolar e pedagógico adaptado. In: SHIRMER, C. R. et al. Atendimento educacional especializado: deficiência física. Brasília SEESP/SEED/MEC. Brasília/DF. 2007. p. 41-53.

BESIO, S. An Italian research project to study the play of children with motor disabilities: the first year of activity. Disability and Rehabilitation, v. 24, n.1, 2002, p. 72-79.

BLACKSTONE, S.; BERG, M.H. Social networks: A communication inventory for individuals with complex communication needs and their communication partners. Monterey: CA: Augmentative Communication, 2003. 
BLANCHE, E. I. Fazer junto com - não fazer para: A recreação e as crianças com paralisia cerebral. In: PARHAM, L. D.; FAZIO, L.S. A Recreação na Terapia Ocupacional Pediátrica. São Paulo: Editora Santos, 2000. p. 202-217.

Play and process: Adult play embedded in the daily routine. In J. Roopnarire (Ed.). Conceptual, social-cognitive, and contextual issues in the field of play. Conn: Ablex Publishing, 2002.

BOBATH, B. Atividade reflexa normal e anormal causada por lesões cerebrais. São Paulo: Manole, 1982.

BOBER, S. F.; HUMPHRY, R.; CARSWELL, H.W.; CORE, A.J. Toddlers, persistence in the emerging occupational of functional play and sel feeding. The American Journal of Occupational Therapy., United States, v.55, n.4, p.369-376, 2000.

BRACEGIRDLE, H. The use of play in occupational therapy for children: what is play? British Journal of Occupational Therapy., United States, v.55, n.33, p. 141-152, 1992.

BRACCIALLI, L. M. P. Tecnologia assistiva: perspectiva de qualidade de vida para pessoas com deficiência. In: Vilarta, R.; Guierrez, G.L.; Carvalho, T.H.P.F.; Gonçalves, A. (Org.). Qualidade de vida e novas tecnologias. Campinas: IPES, 2007, p. 105-114.

Intervenção precoce: contribuições da fisioterapia para área de comunicação alternativa. In: DELIBERATO, D.; GONÇALVES, M. J.; COUTINHO, E. M. (Org.). Comunicação alternativa: teoria, prática, tecnologias e pesquisa. São Paulo: Memnon, 2009, v. 1, p. 285-292.

BRACCIALLI, L. M. P.; MANZINI, E. J.; VILARTA, R. Influência do mobiliário adaptado na performance do aluno com paralisia cerebral espástica: considerações sobre a literatura especializada. Revista Brasileira de Educação Especial, Marília, v. 7, n. 1, p. 25-34, 2001.

nfluencia do mobiliário adaptado na variação angular da curvatura lombar de indivíduos com paralisia cerebral espástica. Fisioterapia Brasil, v. 6, n.2, p.1142-1146, 2005.

BRACIALLI, L. M. P.; MANZINI, E. J.; AIRES, G. Mobiliário escolar adaptado para o deficiente físico: procedência, disponibilidade e critérios para utilização em classes especiais. In: MARQUEZINE, M. C. et al. (Org.). Educação física, atividades motoras e lúdicas, e acessibilidade de pessoas com necessidades especiais. Londrina: Eduel, 2003. p. 193-204. 
BRACCIALLI, L. M. P.; MANZINI, E. J. ; REGANHAN, W. G. Contribuição de um programa de jogos e brincadeiras adaptadas para a estimulação de habilidades motoras em alunos com deficiência física. Temas sobre Desenvolvimento, São Paulo, v. 13, n. 77, p. 3746, 2004.

BRACIALLI et al. Influencia do assento da cadeira adaptada na execução de uma tarefa de manuseio. Revista Brasileira de Educação Especial. Marília: ABPEE, v. 1, n.14, p. 141 154, 2008. Quadrimestral.

BRANCATTI, P.R.; LACERDA, S.T.M. A importância da atividade lúdica para integração de crianças com síndrome de down na pré-escola municipal. In: Manzini, E. J,; Brancatti, P. R. (Org.). Educação especial e estigma: corporeidade, sexualidade e expressão artística. Marília: Unesp-Marília-Publicações, 1999. p. 65-76.

BRASIL. Lei no 9.394. Regulamenta as diretrizes e bases da educação nacional. Diário Oficial da União de 20/12/1996.

Lei de Diretrizes e Bases da Educação Nacional. Brasília: Ministério de Educação/MEC., 1996.

Referencial curricular nacional para a educação infantil. Brasília: Ministério da Educação MEC/SEF, 1998.

Decreto $\mathrm{n}^{\circ} 3298$ de 20/12/1999. Regulamenta a lei $\mathrm{n}^{\circ} 7.853$, de 24 de outubro de 1989. Dispõe sobre a política nacional para a integração da pessoa portadora de deficiência, consolida as normas de proteção, e da outras providências. Diário Oficial da União de 21/12/1999.

. Diretrizes nacionais para a Educação Especial na Educação Básica. Brasília: MEC, SEESP, 2001. 79 p.

Saberes e Práticas da Inclusão: Dificuldades Acentuadas de Aprendizagem: Deficiência Múltipla. Brasília: MEC, SEESP, 2003a.

Sinopse Estatística da Educação Básica - 2002. Brasilia: MEC/INEP, 2003 b.

Decreto $\mathrm{n}^{\circ} 5296$ de 2/12/2004. Regulamenta as leis $\mathrm{n}^{\circ} 10.048$, de 8 de novembro de 2000 que dá prioridade de atendimento às pessoas que especifica, e estabelece normas gerais e critérios básicos para a promoção da acessibilidade das pessoas portadoras de deficiência ou com mobilidade reduzida. Diário Oficial da União de 03/12/2004. 
Educação Inclusiva: A Escola. Brasília: MEC/SEESP, v.03, 2004, 26p.

- Sala de Recursos Multifuncionais: espaços para o Atendimento Educacional Especializado. Brasília: MEC/SEESP, 2006. 3/02/2006.

Lei 11.274. Regulamenta o ensino fundamental de 9 anos. Diário Oficial da União de Política Nacional de Educação Especial na Perspectiva da Educação Inclusiva. Brasília: MEC, SEESP, 2006 b.

. Parâmetros básicos de infra-estrutura para instituições de educação infantil. Brasília: MEC/SEB, 2006c . 45 p.

Atendimento Educacional Especializado - Deficiência Física. Brasília: MEC/SEESP/SEED, 2007.

CAPOVILLA, F. C. Comunicação Alternativa: Modelos teóricos e tecnológicos, Filosofia Educacional e Prática clínica. In: CARRARA, K. (Org.). Educação, Universidade e Pesquisa. Marília: UNESP/Marília Publicações, São Paulo: Fapesp, 2001. p. 179-208.

CARLO, M. M.; LUZO M. C. M. Terapia ocupacional: Reabilitação física e contextos hospitalares. São Paulo: Roca, 2004.

CARVALHO, A. M. P. O uso do vídeo na tomada de dados: pesquisando o desenvolvimento do ensino em sala de aula. Pro-posições, v. 7, n. 1, p. 5-13, 1996.

CARVALHO, R. E. Temas em educação especial. 2. ed. Rio de Janeiro: W V A ed., 2000.

CAT - Comitê de Ajudas Técnicas. Ata da Reunião V, de agosto de 2007 do Comitê de Ajudas Técnicas. Secretaria Especial dos Direitos Humanos da Presidência da República (CORDE/SEDH/PR), 2007a. Disponível em: <http:// http://www.mj.gov.br/corde/comite.aspAcesso em: 16 set. 2009.

CAT - Comitê de Ajudas Técnicas. Ata da Reunião III, de abril de 2007 do Comitê de Ajudas Técnicas. Secretaria Especial dos Direitos Humanos da Presidência da República (CORDE/SEDH/PR), 2007b. Disponível em: <http://www.mj.gov.br/corde/comite.aspAcesso em: 16 set. 2009. 
CAT - Comitê de Ajudas Técnicas. Ata da Reunião VII, de dezembro de 2007 do Comitê de Ajudas Técnicas. Secretaria Especial dos Direitos Humanos da Presidência da República (CORDE/SEDH/PR), 2007c. Disponível http://www.mj.gov.br/corde/comite.aspAcesso em: 16 set. 2009.

CAVALCANTI, A.; GALVÃO, C. Terapia Ocupacional: Fundamentação \& prática. Rio de Janeiro: Guanabara Koogan, 2007.

COLA, P. C., et al. The Influence of Sour Taste and Cold Temperature on Pharyngeal Transit Duration in Patients With Stroke. Arquivos de Gastroenterologia, v. 4, p. 18-21, 2010.

Reabilitação em disfagia orofaríngea neurogênica: sabor azedo e temperatura fria. Revista CEFAC, v. 10, p. 1-2, 2008.

COOK, A. M.; HUSSEY, S.M. Assistive Tecnologies: Principles and Pratice, Mosby. New York: Missouri, Year Book,1995.

Assistive technologies: principles and practice. 2. ed. New York: Mosby, 2002.

COPLEY, J.; ZIVIANI, J. Barriers to the use of assistive technology for children with multiple disabilities. Occupational Therapy International. United States, v.11, n.4, p. 229243, 2004.

CORRÊA, Priscila Moreira. Elaboração de um protocolo para avaliação de acessibilidade física em escolas da Educação Infantil. 2010. 174f. Dissertação (Mestrado) - Faculdade de Filosofia e Ciências, Universidade Estadual Paulista, Marília, 2010.

CRUZ, D. M. C. Brincar é estimular? Preensão, função manual e sua estimulação em pré escolares com paralisia cerebral do tipo hemiparesia espástica. 2006. 152f. Dissertação (Mestrado em Educação Especial) - Universidade Federal de São Carlos, São Carlos, 2006.

DANNA, M. F.; MATOS, M. A. Aprendendo a observar. São Paulo: Edicon, 2006.

DEITZ, J.C., SWINTH, V., WHITE, O. Power mobility and preschoolers with complex developmental delays. American Journal of Occupational Therapy.,United States, v.56, n.1, p.46- 53, 2002.

DELIBERATO, D. . Competição intermodal: inteferência no aprendizado da percepção visual da criança surda. Boletim do Coe, UNESP Marília Publicações, v. 5, p. 83-90, 2000. 
. Ensino do aluno surdo: um esboço sobre métodos e técnicas empregadas na área. In: MANZINI; E. J. (Org.). Linguagem, cognição e ensino do aluno com deficiência. Marília: Unesp-Marília-Publicações, 2001, v. , p. 13-53.

Aspectos teóricos e metodológicos na comunicação alternativa: contribuições para a Educação Especial. Revista Brasileira de Educação Especial, v.10, p.387-388, 2004.

Speech and language therapy in the school: resources and procedures for augmentative and alternative communication. In: VON TETZCHNER, S.; GONÇALVES, M. J. (ed.). Theoretical and methodological issues in research on augmentative and alternative communication. Canada: ISAAC, 2005. P. 116-125.

Acessibilidade comunicativa no contexto acadêmico. In: MANZINI, E. J. (Org.). Inclusão do aluno com deficiência na escola: os desafios continuam. Marília: ABPEE, 2007. p. 25-36.

Comunicação alternativa: informações básicas para o professor In: OLIVEIRA, A. S.; OMOTE, S.; GIROTO, C. M. Inclusão escolar: as contribuições da Educação Especial. São Paulo: Cultura Acadêmica Editora, 2008. v. 1, p. 233-250.

Comunicação Alternativa na escola: habilidades comunicativas e o ensino da leitura e escrita. In: DELIBERATO, D.; GONÇALVES, M. J.; MACEDO, E. C. (Org.). Comunicação alternativa: teoria, prática, tecnologias e pesquisa. $1^{\text {a }}$ ed. São Paulo: MEMNON Edições Científicas, 2009a, v.1, p. 235-243.

Uso de expressões orais durante a implementação do recurso de comunicação suplementar e alternativa. Revista Brasileira de Educação Especial, v.15, p.369-388, 2009b.

Seleção, adequação e implementação de recursos alternativos elou suplementares de comunicação. In: Núcleo de ensino, vol. 1. Org. PINHO, S.Z.; SAGLIETTI, J.R.C, Universidade Estadual Paulista - Publicações, 2005. p. 505-519. ISBN: 85.7139.623-X. Disponível em www.unesp.br/prograd/nucleo2005/index.php no dia 12 de agosto de 2009c.

DELIBERATO, D. ; MANZINI, Eduardo José . Análise de processos comunicativos utilizados por uma criança com paralisia cerebral espástica. In: MANZINI; E. J. (Org.). Educação Especial: Temas atuais. Marília: Marília Unesp Publicações, 2000, v. , p. 35-46.

DELIBERATO, D.; PAURA, A. C. Comunicação alternativa e suplementar (CAS) como recurso de apoio no ensino do conteúdo pedagógico de criança incluída In: Congresso Brasileiro de Comunicação Alternativa - ISAAC - BRASIL, 2., 2007, CAMPINAS. Anais de resumos e trabalhos completos. Campinas: Gráfica Central de Campinas, 2007. p. 1-8. 
DELIBERATO, D.; MOURA, G. M.; MASSARO, M.; PAURA, A. C. Adaptações das tarefas acadêmicas por meio dos recursos de comunicação alternativa e/ou suplementar In: CONGRESSO BRASILEIRO DE COMUNICAÇÃO ALTERNATIVA - ISAAC - BRASIL, 2., 2007, CAMPINAS. Anais de resumos e trabalhos completos. Campinas: Gráfica Central de Campinas, 2007. p.1 -7.

DELIBERATO, D.; ALVES, V. A. Interação do aluno com deficiência sem oralidade frente a diferentes interlocutores. Educação em Questão, v. 34, p.102-126, 2009.

DELIBERATO, D. et al. Comunicação suplementar e alternativa no processo de alfabetização de um aluno com apraxia de fala. In: $17^{\circ}$ congresso brasileiro de fonoaudiologia, 17., 2009, Salvador. Revista brasileira de fonoaudiologia - suplemento. São Paulo: SBFA, 2009. P. 2873.

DIAS, T. R. S.; OMOTE, S. A Entrevista Em Educação Especial: Aspectos Metodológicos. Revista Brasileira de Educação Especial, Piracicaba, v. 2, n. 3, p. 93-100, 1995.

EDYBURN, D. L. Assistive technology and students with mild disabilities. Focus on Exceptional Children, v. 32, n.9, p. 1-23, 2000.

ELIASSON, A. C., KRUMLINDE-SUNDHOLM, L., ROSBLAD, B., BECKUNG, E., ARNER, M., OHRVALL, A. M. The Manual Ability Classification System (MACS) for children with cerebral palsy: scale development and evidence of validity and reliability. Dev Med Child Neurol. v. 48, n. 7, 2006, p. 549-54.

EUSTAT- Empowering Users Through Assistive Technology, 1999. Disponível em: <http://www.siva.it/research/eustat/portugue.html> Acesso em: 04 set. 2009.

FAGUNDES, A. J. F. M. Descrição, definição e registro de comportamento. São Paulo: EDICON, 1985.

FARIA, A. L. G. O espaço físico como um dos elementos fundamentais para uma pedagogia da educação infantil. In: FARIA, Ana Lucia Goulart de; PALHARES, M. (Org.). Educação infantil pós LDB. Campinas: Autores Associados, 2000. p. 67-97.

FERLAND, F. O Modelo Lúdico: o Brincar, a Criança com Deficiência Física e a Terapia Ocupacional. São Paulo: Editora Roca, 2006.

FINNIE, N. R. O manuseio em casa da criança com paralisia cerebral. 3 ed. São Paulo: Manole, 2000. 
FORGUS, R. H. Percepção: o processo básico do desenvolvimento cognitivo. São Paulo: Editora Helder, Ed. Universidade de Brasília, Ed., Universidade de São Paulo, 1971. 526p.

FRONZA, D. F. A Importância dos Jogos Brinquedos e Brincadeiras na Educação Infantil. 2005, 98 f. Trabalho de conclusão da Licenciatura em Pedagogia. Campinas - Universidade Estadual de Campinas, 2005.

FROSTIG,M.; MULLER, H. Discapacidades específicas de aprendizaje en niños: detección y tratamiento. Buenos Aires: Panamericana, 1986. 182p

GALVÃO FILHO, T. A.; HAZARD, D.; REZENDE, A. L. A. Inclusão educacional a partir do uso de Tecnologia Assistiva. Salvador: Editora da Universidade do Estado da Bahia(EDUNEB) - UNESCO, 2007.

GALVÃO FILHO, T. A.Tecnologia Assistiva para uma Escola Inclusiva: Apropriação, Demandas e Perspectivas. 2009, 346 f. Tese (Doutorado em educação) - Faculdade de Educação, Universidade Federal da Bahia, 2009.

GAUZZI, L. D. V; FONSECA, L. F. Classificação da paralisia cerebral. In: LIMA; C. L. A.; FONSECA, L. F. Paralisia cerebral: neurologia, ortopedia e reabilitação. Rio de Janeiro: Guanabara koogan, 2004. p. 37 - 44.

GIANNI, M. A. Paralisia cerebral. In: TEIXEIRA, E. et al. Terapia Ocupacional na reabilitação física. São Paulo: Roca, 2003. p. 89-100.

Aspectos clínicos da paralisia cerebral. In: MOURA; E. W.; SILVA; P.A.C. Fisioterapia: Aspectos clínicos e práticos da reabilitação. São Paulo: Artes médicas, 2005. p.13-25.

Paralisia cerebral: aspectos clínicos. In: MOURA, et al. (Org.). Fisioterapia: aspectos clínicos e práticos da reabilitação. 2 ed. São Paulo: Artes Médicas/ AACD, 2010. p. 13-25.

GITLIN, L. N. Why older people accept or reject assistive technology. Generations. v. 19, p.41-47, 1995.

GLENNEN, S. L. Augmentative an alternative communication assessment strategies. In: GLENNEN, S. L.; DE COSTE, D. C. (Ed) The handbook of argumentative and alternative communication. San Diego: Singular, 1997. p. 149- 192. 
GONZÁLEZ, J. A. T. Educação e diversidade: bases didáticas e Organizativas. Tradução de Ernani Rosa. Porto Alegre: Artmed, 2002.

GRALEWICZ, A. Play deprivation in multihandicapped children. The American Journal of Occupational Therapy., United States, v.27, n.2. 94 p 1973.

GUARDA, N. S.; DELIBERATO, D. Caracterização dos enunciados de um aluno não-falante usuário de recurso suplementar de comunicação durante a construção de histórias. Revista Brasileira de Educação Especial, Marília, v.12, p.269-288, 2006.

HAGEDORN, R. Fundamentos da prática da Terapia Ocupacional. São Paulo: Dynamis Editorial, 1999. p. 39-49.

HELFER, I. C.; OLIVEIRA, R. D.; MIOSSO, S. M. P. O brincar e a realidade de aprendizagem da criança com deficiência física decorrente da paralisia cerebral. In: Arquivos Brasileiros de Paralisia Cerebral, v.1(2). Mennon: edições científicas. p. 26-35, 2005. Quadrimestral

HÉCAEN, H. Las perturbaciones de la perception. 1.ed.. Buenos Aires: Editorial Paidos, 1978. 220p

HERCULIANI, C. E. Desenvolvimento de um software de autoria para alunos deficientes não-falantes nas atividades de contos e recontos de histórias. 2007. 108f. Dissertação (Mestrado) - Faculdade de Filosofia e Ciências, Universidade Estadual Paulista, Marília, 2007.

HUANG, I.C.; SUGDEN, D.; BEVERIDGE, S. Assistive devices and cerebral palsy: factors influencing the use of assistive devices at home by children with cerebral palsy. Child: Care, Health \& Development. v.35, n. 1, p.130-139, 2009.

IBGE. Censo demográfico de 2000. Disponível em: <http://www.ibge.gov.br/censo/> Acesso em: 25 ago. 2009.

INEP. Sinopse estatística da Educação Básica de 2007. Instituto nacional de Estudos e Pesquisas Educacionais Anísio Teixeira (Ministério da Educação), 2008.

JOHNSTON, S.S.; EVANS, J. Considering response efficiency as a strategy to prevent assistive technology abandonment. Journal of Special Education Technology. v.20, n.3, p. 4550, 2005.

JUDGE, S. Constructing an assistive technology toolkit for young children: Views from the field. Journal of Special Education Technology. United States v.21, n.4, p. 17-21, 2006. 
JUDGE S.; FLOYD, K.; JEFFS T. Using an Assistive Technology Toolkit to Promote Inclusion. Early Childhood Educ J., United States, v. 36, p. 121-126, 2008.

JUDGE, S. L.; LAHM, E. A. Assistive technology applications for play, mobility, communication, and learning for young children with disabilities. In Judge S. L.; Parette H. P. Assistive technology for young children with disabilities: A guide to family-centered services. Cambridge, 1998, p. 16-44.

JUDGE, S.; SIMMS, K.A. Assistive Technology Training at the Pre-Service Level: A National Snapshot of Teacher Preparation Programs Teacher Education and Special Education: The Journal of the Teacher Education Division of the Council for Exceptional Children February 2009 32: 33-44.

KENSKI, V. M. Aprendizagem mediada pela tecnologia. Revista Diálogo Educacional, Curitiba, v. 4, n. 10, p. 47-56, 2003.

KING, T.W. Assistive Tecnology: Essential Human Factors. Boston: Allyn and Bacon, 1999.

KREPPNER, K. Sobre a maneira de produzir dados no estudo da interação social. Psicologia: Teoria e Pesquisa. v. 17, n 2, p.97-107. mai-ago, 2001.

LAHM, E. A.; SIZEMORE, L. Factors that influence assistive technology decision-making. Journal of Special Education Technology,United States, v.17, n.1, p. 15-26, 2002.

LAMÔNICA, D. A. C. Linguagem na paralisia cerebral. In: FERREIRA, L. P.; BEFILOPES, D. M.; LIMONGI, S. C. O. (Org.). Tratado de fonoaudiologia. São Paulo: Roca, 2004. p. 967-976.

LANGONE, J.; MALONE, M.; KINSLEY, T. Technology solutiofor young children with developmental concerns. Infants and Young Children, v.11, n.4, p. 65-78, 1999.

LAPLANTE, M.P., HENDERSSHOT, G. E.; MOSS, A. J. Assistive technology devices and home accessibility features: Prevalence, payment, needs, and trends. Advance Data From Vital and Health Statistics, v.217, p. 1-12, 1992.

LAUAND, G. B. A. Fontes de informação sobre tecnologia assistiva para favorecer à inclusão escolar de alunos com deficiências físicas e múltiplas. 2005, 234f. Tese (Doutorado em Educação Especial). Programa de Pós-graduação em Educação Especial, Universidade Federal de São Carlos. São Carlos, 2005. 
LAUFER, A. M. Recomendações para projeto de brinquedos de recreação e lazer adaptados a criança com paralisia cerebral. 2001, 168f. Dissertação (Mestrado em Educação Especial). Programa de Pós-graduação em Educação Especial, Universidade Federal de São Carlos. São Carlos, 2001.

LEONTIEV, A. N. Uma contribuição à teoria do desenvolvimento da psique infantil. In: LURIA, A. R., LEONTIEV, A. N, VYGOTSKY, L. S. In: Psicologia e Pedagogia: bases psicológicas da aprendizagem e do desenvolvimento. São Paulo: Moraes, 1991. p.59-83.

LEFÈVRE, B. Avaliação neuropsicológica da criança. In: Neurologia infantil. São Paulo: Atheneu, p.83 -109, 1995.

LIGHT, J. C. Development of communicative competence by individuals who use AAC. In: LIGHT, J. C.; BEUKELMAN, D. R; REICHLE, J. (Org.). Communicative competence for individuals who use AAC: from research to effective practice. Baltimore: Paul $\mathrm{H}$. Brookes Publishing, 2003. p. 3-38.

LIMONGI, S. C. O. A construção da linguagem na criança paralítica cerebral. In: LIMONGI, S. C. O. Paralisia cerebral: processo terapêutico em linguagem e cognição: (pontos de vista e abrangência). São Paulo: Pró-Fono, 2000. p. 119-142.

Fonoaudiologia informação para a formação: procedimentos terapêuticos em linguagem. Rio de Janeiro: Guanabara Koogan, 2003.

LORENZINI, M. V. Brincando a brincadeira com a criança deficiente: novos rumos terapêuticos. Barueri: Manole, 2002.

LURIA, A. R. Curso de psicologia geral. 2.ed., v.2.Rio de Janeiro: Civilização Brasileira, 1991. 98p

MANZINI, E. J. Recursos pedagógicos para o ensino de alunos com paralisia cerebral. In: Mensagem da APAE. N.84, v.36, p. 17-21, 1999.

Considerações sobre a elaboração de roteiro para entrevista semi-estruturada. In: MARQUEZINE, M. C; ALMEIDA, M. A.; OMOTE, S. (Orgs.). Colóquios sobre pesquisa em Educação Especial, Londrina, Paraná: Eduel, n. 1, p. 11 - 25, 2003.

Tecnologia assistiva para educação: recursos pedagógicos adaptados. In: Ensaios pedagógicos: construindo escolas inclusivas. Brasília: SEESP/MEC, p. 82-86, 2005. 
MANZINI, E. J. ; SANTOS, M. C. F. Portal de ajudas técnicas para a educação: equipamento e material pedagógico para educação, capacitação e recreação da pessoa com deficiência - recursos pedagógicos adaptados. 1. ed. Brasília: MEC, . v. 1, 2002, 56 p.

MANZINI, E. J.; DELIBERATO, D. Portal de ajudas técnicas para a educação: equipamento e material pedagógico para educação, capacitação e recreação da pessoa com deficiência física - recursos para a comunicação alternativa. Brasília: MEC, Secretaria de Educação Especial, 2004. Fasc. 2.

Portal de ajudas técnicas para a educação: equipamento e material pedagógico para educação, capacitação e recreação da pessoa com deficiência física - recursos pedagógicos II. Brasília: MEC, Secretaria de Educação Especial, 2007. Fasc. 4.

MANZINI, E. J. ; DELIBERATO, D. ; BRACCIALLI, L. M. P. . Recursos e estratégias utilizadas no atendimento educacional especializado numa perspectiva inclusiva (2004-2006). In: FREITAS, S. N. (Org.). Diferentes contextos de educação especial/inclusão social. 1 ed. Santa Maria: Palloti, 2006, v. 1, p. 81-86.

MARCUSCHI, L. A. Análise da conversação. São Paulo: Ática, 1986.

MAUAD, A. M. Fotografia e história: possibilidades de análise. In: CIAVATTA, M.; ALVES, N. A leitura de imagens na pesquisa social: história, comunicação e educação. São Paulo: Cortez; 2004. p. 136.

MAYER-JOHNSON, R. The picture communication symbols - P.C.S. - Software Boardmaker. Porto Alegre: Clik Tecnologia Assistiva, 2004.

MAYKUT, P.; MOREHOUSE, R. Beginning Qualitative Research: A Philosophical and Practical Guide. London: Falmer Press,1994.

McDONALD, R, et al. Elation or frustration? Outcomes following the provision of equipment during the Communication Aids Project: data from one CAP partner centre. Child: Care, Health \& Development, v. 34, n.2, p. 223-229, 2008.

McGIBBON, L. B.; LAW, M. The effects of family- centred functional therapy on the occupational performance of children with cerebral palsy. Can Journal Occupational Therapy. v. 80, n.12, p. 36-52, 2003.

MELLO, S. A. Algumas implicações pedagógicas da Escola de Vygotsky para a educação infantil. Pro-posições, Campinas, v. 10, n. 1 (28), 1999. p. 16-27 
Um mergulho no letramento a partir da Educação Infantil. In: PEREZ; M.A.; TORELLI, M.P.S. Caderno temático de formação II - Educação infantil construindo a pedagogia da infância no município de São Paulo. São Paulo, 2004. p.69-76.

Infância e humanização: algumas considerações na perspectiva histórico-cultural. Perspectiva. Florianópolis, v. 25, n. 1, 83-104, jan/jun. 2007.

MISSUNA, C., POLLOCK, N. Play deprivation in children with physical disabilites: the role of the occupational therapist in preventing secondary disability. The American Journal of Occupational Therapy, United States, v.45, n.10, p. 8-18, 1991.

MISTRETT, S. G.; LANE, S. J.; RUFFINO, A. G. Growing and learning through technology: Birth to five. In EDYBURN, D.; HIGGINS, K.; BOONE, R .(Orgs.). Handbook of special education technology research and practice. Whitefish Bay, WI: Knowledge by Design. p. $273-307,2005$.

MOLINA, P.; ARNAIZ, B. Analisis y adaptación de actividades. In: LOPEZ, B.M.P.; ARNAIZ, B. (Orgs). Conceptos fundamentals de Terapía Ocupacioanl. Madrid: Médica Panamericana, 2001. p.233-245.

MOYLES, J. R. A exelencia do brincar. Porto Alegre: Ed Artmed, 2006.

NOETZEL, M. J; MILLER, G. Traumatic brain injury as a cause of cerebral palsy. In: The Cerebral Palsies. London: Butherworth-heinemann, 1998. p. 185-208.

NORTHERN, J. D.; DOWNS, M. P. Audição em crianças. São Paulo: Manole, 1989.

NÓVOA, A. Os professores e a sua formação. 2 ed. Lisboa: Dom Quixote,1995.

NUNES, L. R. O. P. Linguagem e comunicação alternativa: uma introdução. In: NUNES, L. R. O. (Org.). Favorecendo o desenvolvimento da comunicação em crianças e jovens com necessidades educacionais especiais. Rio de Janeiro: Dunya, 2003. p. 1-13.

Um Breve Histórico da Pesquisa da Comunicação Alternativa na UERJ. In: NUNES,

L.R.O.P; PELOSI, M.B.; GOMES, M.R. (Orgs.). Um Retrato da Comunicação alternativa no Brasil - Relato de Pesquisas e experiências. Volume II. Rio de Janeiro: 4 Pontos Estúdio Gráfico e Papéis, 2007. p.19-32.

OKOLO, C. M.; BOUCK, E. C. Research about assistive technology: 2000-2006. What have we learned? Journal of Special Education Technology. v.,22, n.3, p.19-34, 2007. 
OLIVEIRA, A. I. A. A Contribuição da Tecnologia no Desenvolvimento Cognitivo de Crianças Com Paralisia Cerebral. 2004. 259f. Dissertação (Mestrado em Motricidade Humana) - Universidade do Estado do Pará, Belém, 2004.

OLIVEIRA, F. T. de. Estudo do mobiliário escolar durante o desempenho de atividades lúdicas por alunos com paralisia cerebral espástica. 2007. 100f. Dissertação (Mestrado) Faculdade de Filosofia e Ciências, Universidade Estadual Paulista, Marília, 2007.

OLIVETO, J.; MANZINI, E. J. Dificuldades de professores de pré-escola no trabalho de integração de alunos com deficiência. In: MANIZNI, E. J. (Org.) Integração do aluno com deficiência: perspectives e prática pedagógica. Marília: UNESP, 1999. p. 27-56.

OMOTE, S. Algumas tendências (ou modismos?) recentes em Educação Especial e a Revista Brasileira de Educação Especial. Revista Brasileira de Educação Especial, Marília, v. 9, n. 1, p. 25-38, 2003.

OMOTE, S. Inclusão: da intenção à realidade. In: OMOTE, S. (Org.). Inclusão: intenção e realidade, Marília: Fundepe, 2004, p. 1-9.

PALISANO, R., et al. Development and reliability of a system to classify gross motor function in children with cerebral palsy. Dev Med Child Neurol. v. 39, n. 4, 1997, p. 214-23.

PAIVA, P. C. Influência da textura do recurso pedagógico em atividade de encaixe realizada por alunos com paralisia cerebral. 2007. 104f. Dissertação (Mestrado) - Faculdade de Filosofia e Ciências, Universidade Estadual Paulista, Marília, 2007.

PARETTE, H. P.; BROTHERSON, M. J.; HUER, M. B. Giving families a voice in augmentative and alternative communication decision making. Education and Training in Mental Retardation and Developmental Disabilities, v. 35, n. 2, p. 177 - 190, 2000.

PARETTE, H. P.; BROTHERSON, M. J. Family-centered and Culturally Responsive Assistive Technology Decision Making. Infants \& Young Children, v. 17 , n.4, p. 355-367, 2004.

PELOSI, M. B. A comunicação alternativa e ampliada nas escolas do Rio de Janeiro: formação de professores e caracterização dos alunos com necessidades educacionais especiais. 2000, 226 p. Dissertação (Mestrado em Educação) - Universidade do Estado do Rio de Janeiro, Rio de Janeiro, 2000. 
Comunicação alternativa e ampliada nas escolas do Rio de Janeiro. In: NUNES, L.R.O.P. (Org.). Favorecendo o Desenvolvimento da Comunicação em Crianças e Jovens com Necessidades Educacionais Especiais. Rio de Janeiro: Dunya, 2003, p. 203-216.

Por uma escola que ensine e não apenas acolha: recursos e estratégias para a inclusão escolar. In MANZINI, E. J. Inclusão e Acessibilidade. Marília: ABPEE, 2006, p.121-132.

Inclusão e Tecnologia Assistiva. 2008. Volumes I e II, 303f. Tese (Doutorado em Educação) - Programa de Pós-graduação em Educação da Faculdade de Educação, Universidade do Estado do Rio de Janeiro, Rio de Janeiro, 2008.

Tecnologias em comunicação alternativa sob o enfoque da terapia ocupacional. In: DELIBERATO, D.; GONÇALVES, M. J.; MACEDO; E. C. (Org.). Comunicação alternativa: teoria, prática, tecnologias e pesquisa. São Paulo: Memnon Edições Científicas, 2009. p. 163-173.

PERES, R. C. N. C. O lúdico no desenvolvimento da criança com paralisia cerebral espástica. 2003, 242 f. Tese (Doutorado em Educação) - Faculdade de Educação, Universidade de São Paulo, São Paulo, 2003.

PIAGET, J. (1964) O nascimento do jogo. In: . A formação do símbolo na criança: imitação, jogo e sonho, imagem e representação. Rio de Janeiro: Zahar, 1971. 136p.

PINHEIRO, E. M.; KAKEHASHI, T. Y.; ANGELO, M. O uso de filmagem em pesquisas qualitativas. Revista Latino-Americana de Enfermagem, Ribeirão Preto, v. 13, n. 5, p. 717$722,2005$.

PIOVESANA, A. M. S. G. Encefalopatia crônica (Paralisia cerebral): Etiologia, classificação e tratamento clínico. In: FONSECA, L. F.; PIANETTI, G.; XAVIER, C. C. Compêndio de Neurologia Infantil. Rio de Janeiro: Medsi, 2002.

PHILLIPS, B.; ZHAO, H. Predictors of assistive technology abandonment. Assistive Technology, v. 5, n.1, p.36-45, 1993.

PONSONI, A. Comunicação Suplementar e Alternativa no Discurso Narrativo do Aluno com Paralisia Cerebral. 2010. 178f. Dissertação (Mestrado) - Faculdade de Filosofia e Ciências, Universidade Estadual Paulista, Marília, 2010.

PONSONI, A. et al. Equipe multiprofissional na implementação de recursos de comunicação suplementar e alternativa com alunos com deficiência. In: MANZINI, E. J.; MARQUEZINI, 
M. C.; TANAKA, E.D.O.; FUJISAWA, D.S.; BUSTO, R.M. (Org.). Linguagem $e$ comunicação alternativa: Series estudos multidisciplinares de educação especial. $1^{\mathrm{a}}$ ed. Londrina: ABPEE, 2009, v.1, p. 63-70.

PRETO, V. O. Adaptação de livros de literatura infantil para alunos com deficiência visual. 2009. 237f. Dissertação (Mestrado) - Faculdade de Filosofia e Ciências, Universidade Estadual Paulista, Marília, 2009.

PUBLIC LAW 100-407 and 103-218. Technology-related assistance for individuals with disabilities. Act of 1988 as amended in 1994. Disponível em: $<$ http://www.washingtonwatchdog.org/documents/usc/ttl29/ ch24/sec2201.html> Acesso em o4 de jul. 2009.

PUBLIC LAW 108-364. 108th Congress, 2004. Disponível em $<$ http://frwebgate.access.gpo.gov/cgibin/getdoc.cgi?dbname=108_cong_public_ Laws\&doci=f:publ364.108> Acesso em 04 de jul. 2009.

QUIST, R. W.; LLOYD, L. L. Principles and uses os tchecnology. Augmentative and Alternative Communication: a handbook of principles and practices, v. 1, p. 107-126, 1997.

High technology. Augmentative and Alternative Communication: a handbook of principles and practices, v. 1, p. 138-168, 1997.

RADELL, U. Augmentative and alternative communication assessment strategies: seating and positioning. In: GLENNEN; S.L.; DeCOSTE, D.C. Handbook of Augmentative and Alternative Communication, v.01, p.193 - 241, 1996.

REGANHAM, W. G. Recurso e estratégia para o ensino de alunos com deficiências: percepção de professores. Dissertação (mestrado) - Faculdade de Filosofia e Ciência, Universidade Estadual Paulista, Marília, 2006.

REIS, N. M. M.; REZENDE, M. B. Adaptações para o Brincar. In: CAVALCANTI, A; GALVÃO, C. (Org.). Terapia Ocupacional - Fundamentação e Prática. Rio de Janeiro: Guanabara Koogan, v.1, p. 338-344, 2007.

RIEMER-REISS, M.; WACKER, R. R. Factors associated with assistive technology discontinuance among individuals with disabilities. Journal of Rehabilitation. v. 66 n. 3, p. 44-50, 2000. 
ROCHA, A. N. D. C.; DELIBERATO, D. Deficiente físico e o uso da tecnologia assistiva como instrumento facilitador da experiência lúdica no contexto da educação infantil. In: $X$ SEMINÁRIO DA PÓS-GRADUAÇÃO, 2008, Marília. Anais. Marília, 2008. v. 1. p. 1-9.

ROCHA, A. N. D. C., et al. D. Tecnologia assistiva e a experiência lúdica: o uso do brinquedo adaptado como possibilidade terapêutica para o desenvolvimento da criança In: CONGRESSO BRASILEIRO DE EDUCAÇÃO ESPECIAL, 3., E ENCONTRO DE PESQUISADORES EM EDUCAÇÃO ESPECIAL, 4., 2008, São Carlos. Anais. São Carlos, 2008. v.1. p.1 - 10 .

ROCHA, A. N. D. C.; DELIBERATO, D. O uso de recursos de tecnologia assistiva como instrumento facilitador de atividades pedagógicas de crianças com encefalopatia crônica não progressiva In: CONGRESSO BRASILEIRO DE COMUNICAÇÃO ALTERNATIVA ISAAC/BRASIL, 3., 2009, São Paulo. Anais - III Congresso Brasileiro de Comunicação Alternativa - ISSAC/Brasil. Marília: ABPEE, 2009a. p.1 - 9.

A tecnologia assistiva como instrumento facilitador da inclusão escolar de alunos com deficiência física. In: CONGRESSO BRASILEIRO MULTIDISCIPLINAR DE EDUCAÇÃO ESPECIAL, 5., 2009, Londrina. Anais V Congresso Brasileiro Multidisciplinar de Educação Especial. Londrina: ABPEE, 2009b. v.1. p.1150 - 1158.

ROJAS, J. E. A. O indivisível e o divisível na história oral. In: MARTINELLI, M. L. Pesquisa qualitativa: um instigante desafio. São Paulo: Veras, 1999. p. 87-94.

ROSSELL, C. Comunicação e acesso ao currículo escolar para alunos que utilizam sistemas aumnetativos. In: ALMIRALL, C. B.; SORO-CAMATS, E.; BULTÓ, C. R. (Org.). Sistemas de sinais e ajudas técnicas para a comunicação alternativa e a escrita: princípios teóricos e aplicações. São Paulo: Livraria Santos Editora, 2003. p. 121- 133.

ROTHSCHILD, N.; SWAINE, J.; NORRIS, L. Augmentative and alternative communication: management of severe communication disorders in children and adults. Brazil: Workshop, 2001.

ROTTA, N. T. Paralisia cerebral, novas perspectivas terapêuticas. Jornal de Pediatria. Sociedade Brasileira de Pediatria v. 78, n.1, p. 48 -54, 2002.

RUBIN, K. H.; FEIN, G. G.; VANDENBERG, B. Play In: MUSSEN, P.H. (Org.). Handbook of Child Psychology .New York: Jonh Wiley, cap. 1, v.4, p.693-774, 1983. 
SAMESHIMA, F. S. Habilidades expressivas de um grupo de alunos não-falantes durante atividades de jogos. 2006. 130 f. Dissertação (Mestrado em Educação) - Faculdade de Filosofia e Ciências, Universidade Estadual Paulista, Marília, 2006.

SAMESHIMA, F. S.; DELIBERATO, D. Habilidades expressivas de um grupo de alunos com paralisia cerebral na atividade de jogo. Revista da Sociedade Brasileira de Fonoaudiologia, v.14, p. 219-224, 2009a.

Parceria entre especialistas, professor e família no processo de implementação da comunicação alternativa: uma condição necessária. In: CONGRESSO BRASILEIRO MULTIDISCIPLINAR DE EDUCAÇÃO ESPECIAL, 5., 2009b, Londrina. Anais $V$ Congresso Brasileiro Multidisciplinar de Educação Especial.... Londrina: ABPEE, 2009. v.1. p.379- 388 .

SAMESHIMA, F. S, et al. Comunicação alternativa e suplementar no ensino fundamental: adaptações das atividades pedagógicas de um aluno com deficiência física. In: MANZINI, E. J.; MARQUEZINI, M. C.; TANAKA, E.D.O.; FUJISAWA, D.S.; BUSTO, R.M. (Org.). Linguagem e comunicação alternativa: Série estudos multidisciplinares de educação especial. $1^{\text {a }}$ ed.Londrina: ABPEE, 2009, v.1, p. 71-81.

SACKHEIM, G.I. Química e Bioquímica para Ciências Biomédicas. Barueri: Manole, 1998.

SAUDERS I. S. M.; GOODALE, A. The relationship between playfulnnes and copying in preschool children: a pilot study. The American Journal of Occupational Therapy, v.53, n. 2, p. 221-226, 1999.

SCAPPATICCI, A. L. S. S.; IACOPONI, E.; BLAY, S. L. Estudo de fidedignidade interavaliadores de uma escala para avaliação da interação mãe bebê. Revista de Psiquiatria, v. 26, n. 1, p. 39-46, 2004.

SHIRMER, C. R. Formação de professores para atuar na área de comunicação alternativa: uma proposta de abordagem problematizadora. In: DELIBERATO, D.; GONÇALVES, M. J.; MACEDO, E. C. (Org.). Comunicação alternativa: teoria, prática, tecnologias e pesquisa. São Paulo: Memnon Edições Científicas, 2009. p. 264-274.

SCHRAIBER, L. B. Pesquisa qualitativa em saúde: reflexões metodológicas do relato oral e produção de narrativas em estudo sobre a profissão médica. Revista de Saúde Pública, São Paulo, v. 29, n. 1, p. 63-74, 1995.

SCHWARTZWAN, J. S. Paralisia Cerebral. Arquivos Brasileiros de Paralisia Cerebral. São Paulo: Memnon, v.1(1), p. 5-17, 2004. Quadrimestral. 
SILVA, R. G. A eficácia da reabilitação em disfagia orofaríngea. Pró-Fono (Impresso), v. 19, p. 1-2, 2007.

SILVA, R. G. Evidências na Reabilitação da Disfagia Orofaríngea Neurogênica. In: BERRETIN-FELIX, et al. (Org.). (Re)Habilitação Fonoaudiológica: Avaliação da eficácia. São Paulo: Pulso, 2009, v.3 , p. 56 - 73.

SILVA, M. O. Protocolo para prescrição ou adaptação de recursos pedagógicos para alunos com paralisia cerebral. 2010. 195f. Dissertação (Mestrado) - Faculdade de Filosofia e Ciências, Universidade Estadual Paulista, Marília, 2010.

SITTA, K. F. Possibilidades de mediação dos espaços nas brincadeiras e aprendizagem das crianças na educação infantil. 2008. 156f. Dissertação (Mestrado em Educação) Universidade Federal de São Carlos, 2008.

SMITH, M. A.; RYNDAK, D. L. Estratégias práticas para a comunicação com todos os alunos. In: STAINBACK, S.; STAINBACK, W. Inclusão: um guia para educadores. Tradução de Magda França Lopes. Porto Alegre: Artes Médicas Sul, 1999. p. 110-128.

SODRÉ, J; PLETSCH, M. D.; BRAUN, P. A formação inicial e continuada de recursos humanos para a prática docente frente à educação inclusiva. In: NUNES SOBRINHO, F. d'O P. N. (Org.). Inclusão educacional: pesquisas e interfaces. Rio de Janeiro: Livre Expressão, 2003. p. 62-78.

SORO-CAMATS, E. Uso de ajudas técnicas para a comunicação, o jogo, a mobilidade e o controle do meio: uma abordagem habilitadora. In: ALMIRALL, C. B.; SORO-CAMATS, E.; BULTÓ, C. R. (Org.). Sistemas de sinais e ajudas técnicas para a comunicação alternativa e a escrita: princípios teóricos e aplicações. São Paulo: Livraria Santos Editora, 2003. p. 23-41.

SOTO, G.; VON TETZCHNER, S. Augmentative and alternative communication development through participation in socio-cultural activities in shared educational settings. In: VON TETZCHNER, S.; GROVE, N. (Org), Augmentative and alternative communication: developmental issues. London, UK: Whurr, 2003. p. 287-299.

SOUZA, A. M. C. Definição de paralisia cerebral. Resenha de: International Workshop on Definiton and Classification of Cerebral Palsy. Bethesda, Mariland. Arquivos Brasileiros de Paralisia Cerebral, Mennon: edições científicas, v.1, n. 3, p. 50-52, 2005. Quadrimestral.

SPARLING, J. W.; WALKER, D. F., SINGDAHLSEN, J. Play techniques with neurologically impaired preschoolers. The American Journal of Occupational Therapy, v.38, n.9, p 6-11, 1984. 
SMITH, C. J.; CABLE, J. Perceptions of occupational therapists regarding service delivery models of school-based practice. Occupational Therapy Journal of Research. v.16, n. 3, p.2344, 1996.

STEELMAN, J. D. Assistive Technology: Good for all students. Principal Leader Ship (Midlle Level ed.) Reston: v.03, p.62-66, 2002.

SUÀREZ, M. D. et al. Ajudas de alta tecnologia para o acesso a comunicação e a escrita. In: ALMIRALL, C. B.; SORO-CAMATS, E.; BULTÓ, C. R. (Org.). Sistemas de sinais e ajudas técnicas para a comunicação alternativa e a escrita: princípios teóricos e aplicações. São Paulo: Livraria Santos Editora, 2003. p. 43-61.

SULLIVAN, M.; LEWIS, M. Assistive Technology for the very young: Creating responsive environments. Infants and Young Children, v.12, n. 12, p.34-53, 2000.

TAKATORI, M. O Brincar no Cotidiano da Criança com disfunção física: reflexões sobre a clínica da Terapia Ocupacional. São Paulo: Editora Atheneu, 2003.

TEIXEIRA, E.; ARIGA, M.; YASSUKO, R. Adaptações. In: TEIXEIRA, E. et al. Terapia Ocupacional na Reabilitação Física. São Paulo: Roca, 2003. p. 129-173.

TEWEY, B. P.; BARNICLE, K.; PERR, A. The wrong stuff. Mainstream, v.19, n.2, p.19-23, 1994.

TRIVIÑOS, A. N. S. Introdução à pesquisa em ciências sociais: a pesquisa qualitativa em educação. 3 ed. São Paulo: Atlas, 1992.

TABITH, A. J. Distúrbios da comunicação. In: Foniatria: disfonias, fissuras labiopalatais, paralisia cerebral. 2. ed. São Paulo: Cortez, 1980. p. 55-76.

TROMBLY, C. Terapia Ocupacional para a disfunção física. São Paulo: Livraria Editora Santos; 1989. p. 243-253.

VERUSSA, E. O. Tecnologia assistiva para o ensino de alunos com deficiência: um estudo com professores do ensino fundamental. 2009. 96f. Dissertação (Mestrado) - Faculdade de Filosofia e Ciências, Universidade Estadual Paulista, Marília, 2009.

VERZA, R. et al. An Interdisciplinary Approach to Evaluating the Need for Assistive Technology Reduces Equipment Abandonment. Multiple sclerosis, v. 12, p. 88-93. 2006. 
VON TETZCHENER, S. Enunciado de múltiplos símbolos no desenvolvimento da linguagem gráfica. In: NUNES, L.R.O.P. (Org.). Favorecendo o desenvolvimento da comunicação em crianças e jovens com necessidades educacionais especiais. Rio de Janeiro: Dunya, 2003. 171-201.

VON TETZCHENER. Suporte ao desenvolvimento da comunicação suplementar e alternativa. In: DELIBERATO, D.; GONÇALVES, M. J.; MACEDO, E. C. (Org.). Comunicação alternativa: teoria, prática, tecnologias e pesquisa. São Paulo: Memnon Edições Científicas, 2009. p. 14-27.

VON TETZCHNER, S.; MARTINSEN, H. Competências de conversação. In: (Ed.). Introdução à comunicação aumentativa e alternativa. Porto: Porto Editora, 2000. p. 235-259.

VON TETZCHNER, S et al. Inclusão de crianças em educação pré-escolar regular utilizando comunicação suplementar e alternativa. Revista Brasileira de Educação Especial, Marilia, v. 11, n. 2, p.151-184, maio/ago. 2005.

VIGOTSKY, L.S. The problem of the environment. In: VEER, R.; VALSINER, J. (Org.). The Vygotsky reader. Oxford: Blackwell, 1994. p. 338-354.

WALTER, C. F. ; ALMEIDA, M. A. Aplicação do programa de comunicação alternativa e ampliada no contexto familiar de pessoas com autismo. In: LEILA REGINA D’OLIVEIRA DE PAULA NUNES; MIRYAM BONADIU PELOSI; MÁRCIA REGINA GOMES. (Org.). Um retrato da comunicação alternativa no Brasil: relatos de pesquisas e experiências. 345 ed. Rio de Janeiro: Quatro Pontos, 2007, v. 1, p. 194-206.

WASSON, C. A.; ARVIDSON, H. H..; LLOYD, L. L. Low Technology. Augmentative and Alternative Communication: a handbook of principles and practices, v. 1, p. 127-136, 1997.

WINNICOTT, D. W. O brincar e a realidade. Rio de Janeiro: Imago, 1971. 118p.

YOUNG, M.; QUINN, E. Theories and principle of Occupational Therapy. Edinburgh: Churchill Livingstone, 1992.

ZERBINATO, L; MAKITA, L.M; ZERLOTI, P. Paralisia cerebral. In: TEIXEIRA, E. et al. Terapia ocupacional na reabilitação física. Roca, 2003. 
APÊNDICES 


\section{APÊNDICE A}

\section{Termo de consentimento livre e esclarecido para os participantes}

Estamos realizando uma pesquisa no Programa de Pós Graduação em Educação na Universidade Estadual Paulista Julio Mesquita Filho - UNESP/ Marília, intitulada O Deficiente Físico e o Uso da Tecnologia Assistiva como Instrumento Facilitador da Experiência Lúdica no Contexto da Educação Infantil e gostaríamos que participasse da mesma. O objetivo desta é analisar o uso de recursos da Tecnologia Assistiva utilizados como instrumento facilitador da experiência lúdica em crianças com deficiência física no contexto da Educação Infantil. Participar desta pesquisa é uma opção e no caso de não aceitar participar ou desistir em qualquer fase da pesquisa fica assegurado que não haverá perda de qualquer benefício no tratamento que estiver fazendo nesta universidade. Durante a realização da pesquisa serão realizadas três atividades: entrevista com o professor para identificação da rotina de atividades; observação da criança durante a rotina de atividades estabelecida pela professora e atividades programadas, ou seja, serão inseridos materiais adaptados para facilitar a exploração da atividade pela criança com deficiência física. Durante as atividades realizadas será utilizada uma filmadora para registrar as situações vivenciadas pela criança com deficiência física. Após a realização das atividades, as filmagens serão vistas e analisadas para verificar se as crianças selecionadas foram favorecidas com os materiais adaptados. Também fica estabelecido que após a realização da pesquisa os materiais adaptados serão doados para a(s) criança (s) selecionada (s) e os professores serão orientados. As filmagens obtidas durante esta pesquisa serão arquivadas para possíveis análises futuras sob a responsabilidade dos pesquisadores cadastrados no grupo de pesquisa Deficiências Físicas e Sensoriais $(\mathrm{CNPq})$. Caso aceite participar deste projeto de pesquisa gostaríamos que soubessem que:

A) Descrever etapas da coleta de dados, destacando a divulgação dos resultados para fins científicos, como revista, congressos e uso de imagem com a não identificação do sujeito (identidade preservada).

B) Garantir atendimento para as crianças triadas ou avaliadas que apresentarem alterações. 
$\mathrm{Eu}$, portador do $\mathrm{RG}$

responsável pelo(a) participante autorizo a participar da pesquisa intitulada ser realizada no (na)

Declaro ter recebido as devidas explicações sobre a referida pesquisa e concordo que minha desistência poderá ocorrer em qualquer momento sem que ocorram quaisquer prejuízos físicos, mentais ou no acompanhamento deste serviço. Declaro ainda estar ciente de que a participação é voluntária e que fui devidamente esclarecido (a) quanto aos objetivos e procedimentos desta pesquisa.

Nome da criança (comunidade): Data:

Certos de poder contar com sua autorização, colocamo-nos à disposição para esclarecimentos, através do (s) telefone 1434330231 falar com Aila Narene Dahwache Criado Rocha, discente do Programa de Pós Graduação em Educação ou Prof. Dra. Débora Deliberato, Orientadora responsável pela pesquisa e Docente do Programa de Pós Graduação em Educação.

Autorizo,

Data:

(Nome do responsável)

(Nome da criança) 


\section{APÊNDICE B}

\section{Termo de consentimento livre e esclarecido para os professores}

Estamos realizando uma pesquisa no Programa de Pós Graduação em Educação na Universidade Estadual Paulista Julio Mesquita Filho - UNESP/ Marília, intitulada O Deficiente Físico e o Uso da Tecnologia Assistiva como Instrumento Facilitador da Experiência Lúdica no Contexto da Educação Infantil e gostaríamos que participasse da mesma. O objetivo desta é analisar o uso de recursos da Tecnologia Assistiva utilizados como instrumento facilitador da experiência lúdica em crianças com deficiência física no contexto da Educação Infantil. Participar desta pesquisa é uma opção e no caso de não aceitar participar ou desistir em qualquer fase da pesquisa fica assegurado que não haverá perda de qualquer benefício no tratamento que estiver fazendo nesta universidade. Durante a realização da pesquisa serão realizadas três atividades: entrevista com o professor para identificação da rotina de atividades; observação da criança durante a rotina de atividades estabelecida pela professora e atividades programadas, ou seja, serão inseridos materiais adaptados para facilitar a exploração da atividade pela criança com deficiência física. Durante as atividades realizadas será utilizada uma filmadora para registrar as situações vivenciadas pela criança com deficiência física. Após a realização das atividades, as filmagens serão vistas e analisadas para verificar se as crianças selecionadas foram favorecidas com os materiais adaptados. Também fica estabelecido que após a realização da pesquisa os materiais adaptados serão doados para a(s) criança (s) selecionada (s) e os professores serão orientados. As filmagens obtidas durante esta pesquisa serão arquivadas para possíveis análises futuras sob a responsabilidade dos pesquisadores cadastrados no grupo de pesquisa Deficiências Físicas e Sensoriais ( $\mathrm{CNPq}$ ). Caso aceite participar deste projeto de pesquisa gostaríamos que soubessem que:

A) Descrever etapas da coleta de dados, destacando a divulgação dos resultados para fins científicos, como revista, congressos e uso de imagem com a não identificação do sujeito (identidade preservada).

B)Garantir atendimento para as crianças triadas ou avaliadas que apresentarem alterações.

$\mathrm{Eu}$, portador do RG professora do participante aceito 
participar da pesquisa intitulada a ser realizada no (na)

Declaro ter recebido as devidas explicações sobre a referida pesquisa e concordo que minha desistência poderá ocorrer em qualquer momento sem que ocorram quaisquer prejuízos físicos, mentais ou no acompanhamento deste serviço. Declaro ainda estar ciente de que a participação é voluntária e que fui devidamente esclarecido (a) quanto aos objetivos e procedimentos desta pesquisa.

Certos de poder contar com sua autorização, colocamo-nos à disposição para esclarecimentos, através do (s) telefone 1434330231 falar com Aila Narene Dahwache Criado Rocha, discente do Programa de Pós Graduação em Educação ou Prof. Dra. Débora Deliberato, Orientadora responsável pela pesquisa e Docente do Programa de Pós Graduação em Educação.

Autorizo,

Data:

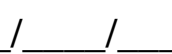

(Nome do professor) 


\section{APÊNDICE C}

\section{Roteiro de Entrevista}

Estamos realizando um estudo para analisar o uso de recursos da Tecnologia Assistiva utilizados como instrumento facilitador da experiência lúdica em criança com deficiência física no contexto da Educação Infantil. Acreditamos que você possa contribuir muito contando um pouco de suas experiências junto ao seu aluno. Você poderia nos dar uma entrevista sobre esse assunto? Eu também necessitaria gravar essa entrevista como forma fidedigna das informações que você pode nos dar. Gostaria de salientar que a sua pessoa será eticamente resguardada independente das informações dadas. Você, então, me permite gravar nossa conversa nestes termos.

1- Qual a rotina escolar da criança?

2- Como você se comunica com a criança?

3- Quais são as atividades lúdicas realizadas na rotina?

4- A criança demonstra interesse durante as brincadeiras? Como ela se expressa?

5- Como ela participa das brincadeiras propostas na rotina?

6- Quais os locais da escola são utilizados com maior freqüência durante as atividades lúdicas?

7- Quais são os brinquedos e brincadeiras utilizados na rotina escolar da criança?

8- Existe algum brinquedo ou brincadeira especifico que atrai a atenção da criança?

9- Qual o brinquedo e/ou brincadeira preferida da criança?

10- Qual o brinquedo e/ou brincadeira a criança não gosta?

11- Como a criança solicita o brinquedo ou brincadeira preferida?

12- Como ela explora o brinquedo?

13- A criança consegue utilizar os brinquedos de forma convencional?

14- A criança explora o brinquedo de forma adequada?

15- Manipula brinquedos ou objetos com intenção?

16- A criança utiliza alguma adaptação ou modificação nos brinquedos ou brincadeiras?

17- A criança tem iniciativa ao brincar? Inventa brincadeiras?

18- A criança necessita de ajuda para brincar? 
19- A criança tem parceiros durantes às brincadeiras? Se sim, quem são?

20- A criança é curiosa ao participar de brincadeiras ou explorar brinquedos?

21- Interage com as outras crianças durante as brincadeiras?

22- Segue as regras das brincadeiras e/ou as colocadas pelo professor?

23- Qual a posição que a criança utiliza durante as brincadeiras?

24- Locomove-se com independência durante as brincadeiras? Se sim como?

25- Você já atuou com outros alunos com alguma deficiência? Qual? Durante quanto tempo?

26- Há quanto tempo você trabalha com esta criança?

27- Você teve alguma orientação?

\section{Dados do entrevistado}

Nome:

Data de nascimento:

Qual a sua formação:

Tempo de experiência na área:

Há quanto tempo você trabalha nesta instituição?

Você fez algum curso a respeito das deficiências?

\section{Dados da criança}

Nome:

Data de nascimento:

Escola:

Serie:

Tipo de deficiência:

Data da entrevista: 


\section{APÊNDICE D}

Protocolo de Identificação de Rotina Escolar

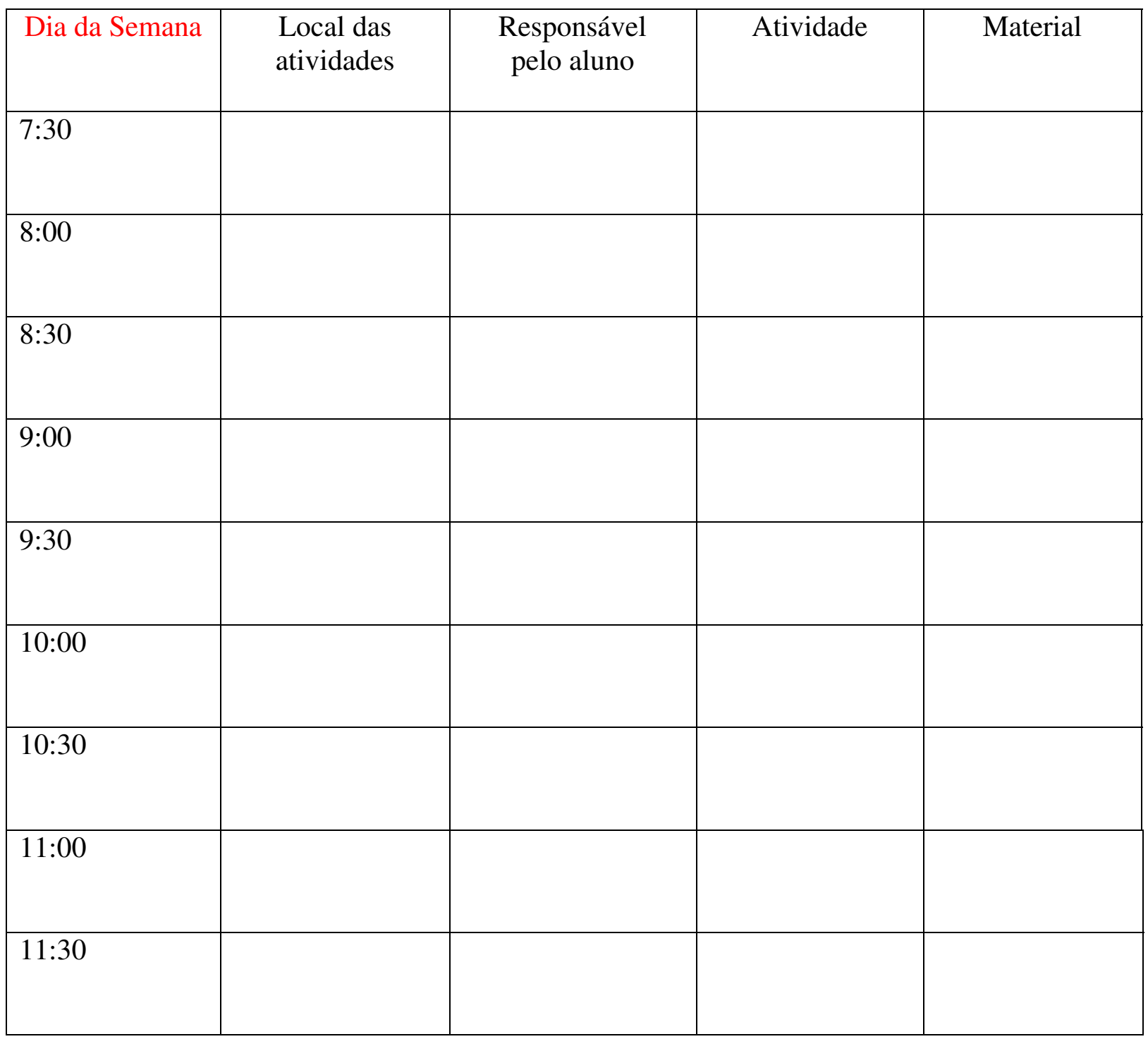




\section{APÊNDICE E}

Protocolo de caracterização e dimensões do recurso - Representação da idéia

Nome:

Data de Nascimento:

Data:

Diagnóstico:

\section{Recurso:}

\begin{tabular}{|c|c|}
\hline Estruturas F & \\
\hline Tamanho & $\begin{array}{l}\text { ( ) grande } \\
\text { ( ) pequeno } \\
\text { ( ) médio } \\
\text { Medidas : }\end{array}$ \\
\hline Peso & $\begin{array}{l}\text { ( ) pesado } \\
\text { ( ) leve } \\
\mathrm{Kg} \text { : }\end{array}$ \\
\hline Consistência & $\begin{array}{l}\text { ( ) mole } \\
\text { ( ) duro } \\
\text { ( ) firme } \\
\text { Especificar: }\end{array}$ \\
\hline Textura & $\begin{array}{l}\text { ( ) áspero } \\
\text { ( ) liso } \\
\text { ( ) macio } \\
\text { Especificar: }\end{array}$ \\
\hline Forma & $\begin{array}{l}\text { ( ) circular } \\
\text { ( ) retangular } \\
\text { ( ) quadrado } \\
\text { ( ) triangular } \\
\text { ( ) outras formas } \\
\text { Especificar: }\end{array}$ \\
\hline Habilidades & \\
\hline Cor & $\begin{array}{l}\text { ( ) vermelho } \\
\text { ( )azul } \\
\text { ( ) amarelo } \\
\text { ( ) verde } \\
\text { ( ) branco } \\
\text { ( ) preto } \\
\text { ( ) Colorido } \\
\text { ( ) duas cores } \\
\text { ( ) três cores }\end{array}$ \\
\hline
\end{tabular}




\begin{tabular}{|l|l|}
\hline \multicolumn{1}{|l|}{} & $\begin{array}{l}\text { ( ) mais de três cores } \\
\text { ( ) outras } \\
\text { Especificar: }\end{array}$ \\
\hline Contraste & $\begin{array}{l}\text { ( ) preto x branco } \\
\text { ( ) branco x preto } \\
\text { ( ) vermelho x branco } \\
\text { ( ) branco x vermelho } \\
\text { ( ) amarelo x preto } \\
\text { ( ) preto x amarelo } \\
\text { ( ) outros } \\
\text { Especificar: }\end{array}$ \\
\hline Coordenação viso motora & Especificar: \\
\hline Relação espacial & Especificar: \\
\hline Posição espacial & Especificar: \\
\hline Figura fundo & Especificar: \\
\hline Constância perceptual & Especificar: \\
\hline Memória visual & Especificar: \\
\hline Estrutura auditiva & Especificar: \\
\hline Presença de som & Especificar: \\
\hline Reconhecimento do som & Especificar: \\
\hline Compreensão do som: & $\begin{array}{l}\text { ( ) alto } \\
\text { ( ) baixo } \\
\text { ( ) grosso } \\
\text { ( ) fino } \\
\text { ( ) forte } \\
\text { ( ) fraco } \\
\text { ( ) longo } \\
\text { ( ) curto } \\
\text { ( ) outros } \\
\text { Especificar: }\end{array}$ \\
\hline $\begin{array}{l}\text { Sensação do som } \\
\text { (intensidade, frequência, duração) }\end{array}$ & Especificar: \\
\hline Estrutura Compreensão: & Especificar: \\
\hline Figura fundo auditiva: & Especificar: \\
\hline Memória auditiva & Especificar: \\
\hline
\end{tabular}




\begin{tabular}{|l|l|}
\hline Comandos simples & Especificar: \\
\hline Comandos complexos & Especificar: \\
\hline Expressão: & Especificar: \\
\hline Vocabulário & Especificar: \\
\hline Extensão de enunciados &
\end{tabular}


ANEXOS 
ANEXO A

Parecer de Aprovação do Comitê de Ética

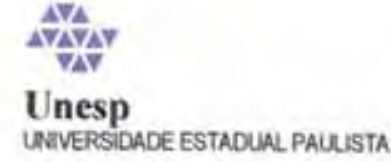

FACULDADE DE FILOSOFIA E CIÊNCIAS COMITE DE ÉTICA EM PESQUISA Fone: $(0 \times x \times 14) 3402-1346$ Fox: (Oxx14) 3422-1302 www marilia unesp br/cep e-mail cep Pmarilia unesp br

\section{PARECER DO PROJETO N’2482/2008}

DENTIFIEACAO

1. Titulo do Projeto Deficiente fisico e o uso da tecnologia assistiva como instrumento facilitador da experiência tùdica no contexto da educaçăo infanti.

2. Pesquisador Responsável: Débora DeliberatolAla Narene Dahawache Criado Rocha

3. Instituiçăo do Pesquisador. Faculdade de Filosofia e Ciências da Universidade Estadual Paulista - Campus de Marilia

4. Apresentaçăo ao CEP: $10 / 07 / 2008$

5. Apresentar relatorio em: Semestraimente đurante a realizaçăo đa pesquisa.

RTIETVES

Analisar o uso dos recursos da "tecnologia assistiva" utilizados como instrumento facilitador da experiencia lúdica em crianças com deficiência fisica no contexto da educeçăo infantil.

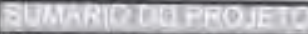

A pesquisa, a ser realizada com cnanças com deficiência fisica, será realizada em trés etapas: entrevista com os professores, observaçẩo do brincar em sala de aula e intervençăo utilizando recursos adequados através da tecnologia assistiva. Para a análise dos dados será realizada a transcriçẫo des entrevistas e filmagens, os registros continuos e os protocolos de identificaçấo do uso dos recursos. Acredita-se que a tecnologia estudada possa favorecer a independencia dos sujeitos em sala de aula, dando condiçobes para se colocar em prática as suas potencialidades.

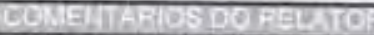

O projelo atende às exigéncias da Resolução 196/96 do Conselino Nacional de Saúde, especiaimente no que tange às exigências de consentimento fivre e esclarecido (art. IV) e protocolo de pesquisa (art VI), Nâo há risco a integridade fisica e/ou mental dos sujeitos da pesquisa. As pendências foram devidamente sanadas. Pelo exposto sou de parecer favorável a aprovaçalo do presente projeto

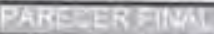

O CEP da FFC da UNESP após acatar o parecer do membro relator previamente aprovado para o presente estudo e atendendo a todos os dispositivos das resoluçbes 196/96 e complementares, bem como ter aprovado o Termo de Consentimento Livre e Esciarecido como também todos os anexos incluidos na pesquisa resolve aprovar o projeto de pesquisa 
supracitado.

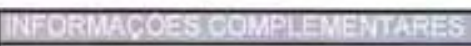

Aprovado na reuniáo do CEP de 27/08/2008

Dr. Edvaldo Soares

Prosidente do CEP

Prof. Dr. Tullo Vigevani

Diretor 
ANEXO B

Autorização da Secretária Municipal de Marília

\author{
PREFEITURA MUNICIPAL DE MARÍLIA \\ SECRETARIA MUNICIPAL DA EDUCAÇĀO \\ NÚCLEO DE APOIO PSICOPEDAGÓGICO \\ Rua Lima e Costa, 693 - CEP 17501-500 - Bairro Alto Cafezal. \\ Fone. 3433-9095 - MARÍLIA - S.P.
}

Marilia. 22 de julho de 2008

\author{
AUTORIZACÃO
}

\begin{abstract}
A Coordenadora do Núcleo de Apoio Psicopedagógico, Prof. Aurea Lủcia Rodrigues Bravo, no uso de suas atribuições legais, autoriza a Terapeuta Ocupacional do CEES - Centro de Estudos em Educação e Saúde - UNESP, Aila Narene Dahwache Criado Rocha, RG 29.464.929-3, discente do Programa de Pós Graduaçấo em Educação da UNESP-Marilia, a apresentar projeto de pesquisa junto aos professores da Rede Municipal de Ensino de Marilia que tenham em suas salas de aula crianças com deficiência física ou múltíplas incluidos.

Salientamos que a autorizặăo para a pesquisa é de incumbẻncia da Direção da Escola que tem autonomia para avaliar o Projeto e a pesquisa propriamente dita

Sendo o que tínhamos a tratar, firmo a presente autorizaçăo,

Atenciosamente.
\end{abstract}

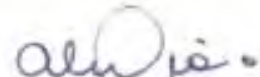

Prof Aurea Lúcia Rodrigues Bravo Ferreira

Coordenadora do Núcleo de Apoio Psicopedagogico

Aos Diretores das Escolas Municipais de Educação Infautuil - EMEls.

Marilia - SP 